\title{
Sufism in the West
}

With the increasing Muslim diaspora in post-modern Western societies, Sufism intellectually as well as sociologically - may eventually become mainstream Islam itself due to its versatile potential, especially in the wake of what has been called the failure of political Islam world-wide. Sufism in the West provides a timely account of this subject and is primarily concerned with the latest developments in the history of Sufism and elaborates the ideas and institutions which organise Sufism and folkreligious practices.

The topics discussed include:

- The orders and movements

- Their social base

- Organisation and institutionalisation

- Recruitment-patterns in new environments

- Channels of disseminating ideas, such as ritual, charisma, and organisation

- Reasons for their popularity among certain social groups

- The nature of their affiliation with the countries of their origin

Sufism in the West is essential reading for students and academics with research interests in Islam, Islamic History and Social Anthropology.

John Hinnells is former Professor and founding chair of the Department for the Study of Religion at the School of Oriental and African Studies, London University. His main research interest is in Zoroastrianism and has also edited the New Penguin Dictionary of Religions and the New Penguin Handbook of Living Religions.

Jamal Malik is Chair of Religious Studies and Islamic Studies at the University of Erfurt, Germany. His areas of interest and research are Islamic Religion, Social History of Muslim South Asia, Colonialism and Political Islam, Islamic Mysticism and Muslims in the West. 



\title{
Sufism in the West
}

\author{
Edited by \\ Jamal Malik and John Hinnells
}

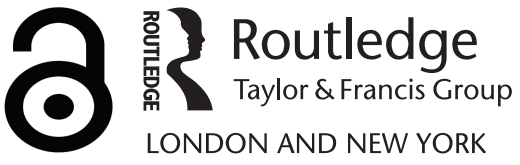


First published 2006 by Routledge

Published 2017 by Routledge

2 Park Square, Milton Park, Abingdon, Oxon OX14 4RN

711 Third Avenue, New York, NY 10017, USA

Routledge is an imprint of the Taylor E Francis Group, an informa business

Copyright (C) 2006 Editorial matters and selection, Jamal Malik and John Hinnells; individual chapters their contributors

Typeset in Garamond by Keyword Group Ltd, Wallington

The Open Access version of this book, available at www.tandfebooks.com,

has been made available under a Creative Commons Attribution-Non Commercial-

No Derivatives 4.0 license.

British Library Cataloguing in Publication Data

A catalogue record for this book is available from the British Library

Library of Congress Cataloging in Publication Data

A catalog record for this book has been requested

ISBN13: 978-0-415-27407-4 (hbk)

ISBN13: 978-0-415-27408-1 (pbk) 


\section{Contents}

List of contributors vii

Preface $\quad x$

Introduction $\quad 1$

JAMAL MALIK

1 Literary productions of Western Sufi movements 28 MARCIA HERMANSEN

2 Persian Sufism in the contemporary West: reflections on the Ni'matu'llahi diaspora

LEONARD LEWISOHN

3 The evolution of the Naqshbandi-Mujaddidi: Sulaymançis in Germany

GERDIEN JONKER

4 Third-wave Sufism in America and the Bawa

Muhaiyaddeen Fellowship

GISELA WEBB

5 Transnational Sufism: the Haqqaniyya

JORGEN S. NIELSEN, MUSTAFA DRAPER AND GALINA YEMELIANOVA

6 Aspects of the Naqshbandi-Haqqani order in North America DAVID W. DAMREL

7 Seekers on the path: different ways of being a Sufi in Britain 
Contents

8 Learning the lessons from the neo-revivalist and Wahhabi movements: the counterattack of the new Sufi movements in the UK

RON GEAVES

9 Popular Islam in northern Pakistan and its reconstruction in urban Britain

ROGER BALLARD

Glossary 


\section{List of contributors}

Roger Ballard is an anthropologist, and Director of the Centre for Applied South Asian Studies in the University of Manchester. He has a long-standing interest in all aspects of the development of Britain's many South Asian communities, and has carried out extensive ethnographic research in the UK, as well as in both Indian and Pakistani Punjab. The author of many articles, he edited Desh Pardesh: the South Asian Presence in Britain (London: Hurst, 1994).

David W. Damrel teaches in the Department of Religious Studies at Arizona State University and has research interests in contemporary and early modern Islamic mysticism. His current research project investigates mysticism and dissent in contemporary transnational Muslim communities. Some of his publications include 'Muslim Spaces in South Asia', in Sacred Places and Modern Landscapes, (ed. Ronald A. Lukens-Bull, 2003), and 'The "Naqshbandi Reaction" Reconsidered', in Beyond Turk and Hindu (ed. David Gilmartin and Bruce Lawrence, Gainesville: University Press of Florida, 2000).

Mustafa Draper is Research Fellow at the Centre for the Study of Islam and ChristianMuslim Relations (CSIC), Department of Theology, University of Birmingham, UK.

Ron Geaves is Professor of Religious Studies at University College, Chester. He is particularly interested in Muslim, especially Sufi, diasporas in the West. His major publications are Sectarian Influences within Islam in Britain (Leeds: University of Leeds, 1996), Sufis of the West (Cardiff: Cardiff Academic Press, 2000) and Islam and the West post 9/11 (Aldershot: Ashgate, 2004), edited with Yvonne Haddad, Theodore Gabriel and Jane Smith. His latest book, Aspects of Islam, is published by Darton, Longman and Todd.

Marcia Hermansen is Professor of Islamic Studies in the Theology Department of Loyola University, Chicago. She works both on classical Islamic thought and on contemporary topics such as Muslims in America and Western Sufi movements. Publications include The Conclusive Argument from God. Shab Wali Allah of Delhi's Hujjat Allah al-Baligha (Brill: Leiden, 1997), and 'Islamic Religious Healing in Chicago: Intersections of South Asian Sufi, American, and Islamic Models' for Religious Healing in America (ed. Susan Sered and Linda L. Barnes, Oxford, 2004). 
John Hinnells, prior to retirement, was Professor of Comparative Religion at Manchester and the School of Oriental and African Studies, London. He now works at Liverpool Hope University College, part time, and is a Senior Member of Robinson College, Cambridge. His main area of research is on the Parsis (Zoroastrians in Britain, Oxford Clarendon Press, 1996 and The Zoroastrian Diaspora, Oxford: Clarendon Press, 2005). He is also interested in questions of theory and method in the study of religion (see Companion to the Study of Religion, Routledge, 2005).

Gerdien Jonker works at the Department of Social and Comparative Anthropology, Viadrina-University Frankfurt (Oder). Recent publications are, Eine Wellenlänge zu Gott: Der Verband der Islamischen Kulturzentren in Europa (Bielefeld: Transcript Verlag, 2002); Female Inroads into Muslim Communities: Reconstructions of Knowledge, Community, and Communication, (ed. with Tuula Sakaranaho, Social Compass, 2003/1); The Politics of Visibility: Young Muslims in European public spaces (with Valérie Amiraux, Bielefeld, Transcript Verlag, 2005).

Leonard Lewisohn is Research Associate at the Department of Academic Research and Publications, The Institute of Ismaili Studies, London, UK. He is also Iran Heritage Foundation Fellow in Classical Persian and Sufi Literature at the Institute of Arab and Islamic Studies of the University of Exeter. Lewisohn is a specialist on Sufi literature and Persian language. His major publications are the three-volume single set entitled The Heritage of Sufism (Oxford: Oneworld Publications, 1999), Beyond Faith and Infidelity: The Sufi Poetry and Teachings of Mabmud Shabistari (London: Curzon Press, 1995), and The Wisdom of Sufism (Oxford: Oneworld, 2001).

Jamal Malik is Professor of Islamic Studies at the University of Erfurt. He works both on Muslims in South Asia and Europe. Publications include The Colonialization of Islam (New Delhi: Manohar and Lahore: Vanguard, 1996), Islamische Gelehrtenkultur in Nordindien (Leiden: Brill, 1997). He edited Perspectives of mutual encounters in South Asian History 1760-1860 (Leiden: Brill, 2000), Muslims in Europe: From the Margin to the Centre (Münster: LIT, 2004), and Religious Pluralism in South Asia and Europe (New Delhi: Oxford University Press, 2004).

Jorgen S. Nielsen is Professor of Islamic Studies, Centre for the Study of Islam and Christian-Muslim Relations (CSIC), Department of Theology and Religion, University of Birmingham, UK. Current research interests concentrate on the Islamic debate on religious pluralism and relations with the 'West'. His recent publications include Muslim Networks and Transnational Communities in and Across Europe, (ed. with S. Allievi, Leiden: Brill, 2003), and Muslims in Western Europe (Edinburgh University Press, 3rd edn, 2004).

Gisela Webb is Professor of Religious Studies, Seton Hall University, USA. Her publications include 'Expressions of Islam in America', 'Sufism in America', and 'Subud' in America's Alternative Religions, (ed. T. Miller, SUNY Press, 1995), her anthology, Windows of Faith: Muslim Women Scholar-Activists in the United States (ed. G. Webb, Syracuse University Press, 2000), 'Themes of Wisdom in Dialogue' in 
Beacon of Light: Essays in Honor of Seyyed Hossein Nasr (ed. M. Faghfoory, Fons Vitae Press, 2003), and 'Death and Dying in Islam: This Day Your Sight is Made Keen' in Death and Dying in World Religions (ed. L. Bregman, Pearson Press, 2004).

Pnina Werbner is Professor of Social Anthropology at Keele. She is the author of The Manchester Migration Trilogy, which includes 'The Migration Process' (Berg, 2002), 'Imagined Diasporas among Manchester Muslims' (Santa Fe, 2002) and 'Pilgrims of Love' (London, 2003), and has edited a number of books on various subjects and authored numerous articles and chapters in professional journals and books. Her fieldwork has included research in Britain, Pakistan and Botswana where she is studying Women and the Changing Public Sphere. She is co-editor of the Postcolonial Encounters series published by Zed Books.

Galina Yemelianova is Senior Research Fellow at the Centre for Russian and East European Studies, University of Birmingham. Dr Yemelianova is a specialist in Arabic and Islamic Studies. Current research concentrates on Islam and ethnopolitics in the North Caucasus. Recent publications are Russia and Islam: A Historical Survey (Palgrave, 2002) and Private and Public Faces of Islam in Russia (Curzon, 2002). 


\section{Preface}

The contestations of the Islamic character of Sufism or Islamic mysticism as a prominent contemporary issue in the West, as well as in Muslim majority areas, call for attention. This is particularly true in the face of the expansion of Sufism, both in an organized way and in the form of its many lived, sometimes unorthodox, realities which provide for a variety of meaningful identity- and solidarity-giving articulations and institutional patterns. In order to understand and discuss these rather new and contemporary phenomena, an international workshop on 'Islamic Mysticism in the West' took place in Buxton, Derbyshire on 22-24 July 2001, at the initiative of members of the Religious Studies Department of the University of Derby. It was financially supported by The British Academy, the Spalding Trusts and the Institute of Ismaili Studies, to which the editors are most grateful. The primary concern of the workshop was to try to comprehend the new mystical Islam in all its complexity, without of course neglecting its historical context. Examples of this new context are multifarious ideas and methods, as well as complex institutions which build on and recur to those evolved throughout history in Muslim-dominated regions in different phases.

This volume is the collection of papers presented at the above-mentioned workshop, which were later revised in the light of fruitful and engaging discussions that took place in a collegial atmosphere. The topic is a new and ground-breaking field with a variety of issues. This volume will provide important advances in what is an exciting new subject for research, for it focuses on the actors, vehicles, channels and ideas, as well as the role of mystical and folk-religious repertory in diasporic contexts. However, this volume is far from being a definitive contribution to what is an ocean without a shore, and we look forward to further studies and hope that our contribution will stimulate interest in this area.

As far as the system of transliteration is concerned, Urdu, Arabic, Persian, Turkish, Hindi and Sanskrit words have been written without diacritical marks, using a slightly altered version of the format in The Encyclopaedia of Islam (New Edition, 1986-2004, Leiden: Brill), unless otherwise noted. It should be emphasized that the lack of diacriticals is aimed at making these studies accessible to a wider audience in comparative studies of religion.

Jamal Malik 


\title{
Introduction
}

\author{
Jamal Malik
}

As is evident from the number of publications in recent years, research on Muslim diasporic mystical movements has gradually increased, reflecting the rising popularity of Sufism among diverse groups, including immigrant Muslims, Western-born children of migrant parents and converts. There are many examples of the popularity and prominence of Sufism in Europe and the USA, such as the conversion to and initiation into diasporic Sufi organizations, the poetry of the famous medieval Sufi poet Jalal al-Din Rumi, performances of the Whirling Dervishes, and a number of conferences on Sufism. The latter certainly indicates a growing degree of interest among Western scholars in analysing the broader implications of these developments. In contrast, argued from the mainstream perspective, we may hardly find this intellectual curiosity regarding contemporary mystical movements in the diaspora among non-Muslims, as well as among Muslims in contemporary Muslim-majority countries, where Sufi ideas and institutions are tendentiously marginalized and often portrayed as being virtually non-existent. In fact, organized Sufism may take different forms, at times witnessing a revival in some Muslim majority areas for quite different reasons (see below). ${ }^{1}$

There seems to be a latent, as well as an overt, feeling that the analysis of Sufism in the West has been neglected in academic discourse so far. This impression might derive in the first place from the perception that Sufism in the West, as well as other folk-religious practices, has been popular among immigrant groups only, especially in Western Europe. Marginalized as migrant communities were and are, they were the only ones still involved in the even more marginalized tradition of their religion: Sufism. This perception of double marginalization corresponds to the overall academic study of religion, the study of which is more or less determined by monotheistic or univocal perspectives and thus singularizing distortions. This might hark back to an orientalist approach which tends to ignore the existence of religious pluralism and reduces Islamic tradition to monolithic essentialism, thereby silencing the multivocality of the Muslim articulations. But there is also the other side of Orientalism: in addition to the essentialization of Islam as fundamentalism, there is also a longstanding romantic idealization of Eastern spirituality. ${ }^{2}$

In the light of this tendency, one may safely assume, therefore, that it will require a great hermeneutic effort - especially in Muslim-majority countries - before the academic study of religion frees itself from paradigms which either stigmatize internal 


\section{Introduction}

religious differences as heresies, ignore them as irrelevant, or render them innocuous through classifications such as mysticism and apocalypticism. Certainly, the reactions of the leading decision-making bodies within a religion against such 'marginal' phenomena vary, ranging from stigmatization by categories such as 'heretic' or 'heresy' to fundamental criticism, official condemnation and active oppression, as is still the case in several Muslim countries. ${ }^{3}$ This development, indeed, seems to confuse academic study with internal religious politics.

From an insider's perspective, this tendency seems to be the result of an approach to religion which originates in the normative demands of organized monotheistic and univocal religious traditions. This perspective from within may be complemented by the one from outside, for example through the likes of sociological investigations which have focused on the economic, moral, legal, political or aesthetic functions of Islam. Such studies, however, often took into account only a single long-term, textually transmitted and usually organized religious tradition in a particular geographical area.

One may also encounter reciprocity between outsiders' academic descriptions and insiders' religious practice: As has been pointed out elsewhere, exponents of the academic study of religion persist in the naive belief that they are only dispassionate observers, which is better said than done. There is actually a relationship between mutual interrelationship of religion and its academic study. ${ }^{4}$ Formulated more sharply, invested by appropriate authority, in most cases academic discourse originally created, or even established, the category of religion, as it developed a normative effect on the understanding of religions in cultural discourses. The relationship between religion, in this case Sufism and folk religion, and the academic study of religion therefore entails an inherent interrelatedness between categories of religio-historical knowledge and self-representations of Sufis, as well as an interdependent relationship between academia and popularized or public opinion about Sufism.

The present volume aims to clarify some of these issues by raising and problematizing a variety of themes, as they evolved against the background of a versatile history of Islamic mysticism. In addition, certain prevailing assumptions about the relationships and interactions of Sufism with other Muslim movements as well as with non-Muslims are questioned. These issues are debated from theoretical, as well as from empirical, perspectives of various disciplines, including history, social anthropology, comparative religion, theology and Islamic studies. It seems proper, however, to provide the necessary setting in the form of a brief history of Islamic mysticism as it has evolved over time and space, before engaging in the introduction some of the important themes as they occur in the chapters.

\section{A brief historical survey of Islamic mysticism ${ }^{5}$}

It is stated both by scholars of mysticism and by mystics themselves that experimenting with Islamic religion in different ways to find the inner path to 'salvation' perceived as Sufism - does not necessarily mean that mysticism in Islam is inimical to what has been called orthodox Islam, which developed its own dogmatism in the 
evolution of major law schools. Mystics claim to be able to interpret the purely literal world of the Qur'an as well as its spirit. Like other Muslims they want to emulate the life of Prophet Muhammad, to 'sunnatize' their life-worlds, and perform imitatio Muhammadi. In addition to this more or less literal negotiation with religious truth, salvation or asceticism, later Sufis strove to establish personal contact with God through the person of the Prophet, who is often perceived as still living and present.

As Sufism provided different forms of cultural articulation, it did not develop unilaterally as a reaction to orthodoxy and legalistic rigorism but at times it also complemented and participated in these developments. Similarly, it seems questionable to talk about an antagonism between shari' a (law) and tariqa (Sufi path) in Islam, because mysticism in Islam does not contradict orthodox law and orthopraxy per se. Instead it builds its foundation upon law and orthopraxy by accepting the basis of the exoteric (zabir) and the mundane which itself is sacralized by following the law. However, it does not stop with the rationally and sensorally perceivable law. Rather, it claims to observe the soul and its experiences as well, so as to intensify these sacralized experiences through some kind of spiritual economy, or hidden sciences, considered to be enlargements upon the exoteric knowledge and implementation of law. As it stands, mysticism can be considered as the internal (batin) view of Islam, focused on the latent mystery of the Qur'an. And since the experience is acknowledged as an inspiration of divine perspective, Sufis consider the law (shari ${ }^{6}$ ) and the path (tariqa) not necessarily as opposites but necessary complementaries.

Similarly, Islamic mysticism is as little monolithic as is Islamic law or Islamic 'orthodoxy' or Islamic fundamentalism. Instead it is highly pluralistic, complex, divergent and at times contradictory. There were personal differences among mystical masters in the ways to teach Sufism, so that mystical ideas changed from person to person, and from group to group, depending on their contexts and functions. There were local differences such as the oppositions between Mesopotamia and Khurasan, Baghdad and Nishapur. Simply speaking, one region was known for its asceticism, the other for its hedonism. While the impact of a certain school was not necessarily restricted to one single place, local styles could change through the encountering with other influences. In the face of these differences, cleavages and varieties in Sufism, it seems difficult to generalize about its ideas and developments, but later generations of mystics have always been trying to classify the scattered ideas of their ancestors, thereby rationalizing their own experiences, as seemed to have happened for example in the twelfth and thirteenth centuries, Ibn 'Arabi (d. 1240) being one example, or later in the seventeenth and eighteenth centuries, when the Indian Shah Wali Allah (d. 1762) synthesized different perspectives. ${ }^{6}$ In the course of time, their classifications were adopted by orientalists in the nineteenth century and also functionally revalued at times - among others in the sense of a litérature de surveillance, ${ }^{7}$ mostly to serve colonial purpose. In this context certain clichés and stereotypes evolved, such as the idea of one monolithic 'Islamic mysticism' or tasawwuf being the alternative 'tolerant and spiritual aspect of Islam'.

Similarly, there are different and divergent opinions about the etymology of the term 'Sufi'. It took the mystics three generations to discuss the origins of the word, 


\section{Introduction}

as can be gleaned from the first Persian treatise on Sufism written by 'Ali b. 'Uthman al-Jullabi al-Hujwiri (d. 1071). His opinion is given in the following passage:

The true meaning of this name [ahl al-tasawwuf; J.M.] has been much discussed and many books have been composed on the subject. Some assert that the Súfí is so called because he wears a woollen garment (jáma'-i súf); others that he is so called because he is in the first rank (saff-i awwal); others say it is because the Súfís claim to belong to the Asháb-i Suffa [in Medina; J.M.] with whom may God be well-pleased! Others, again, declare that the name is derived from safá (purity). These explanations of the true meaning of Súfíism are far from satisfying the requirements of etymology, although each of them is supported by many subtle arguments .... I said that safá (purity) is the opposite of kadar (impurity), and kadar is one of the qualities of Man. The true Súfí is he that leaves impurity behind .... 'Súfí' is a name which is given, and has formerly been given, to the perfect saints and spiritual adepts .... 'He that is purified by love is pure, and he that is absorbed in the Beloved and has abandoned all else is a 'Súfí'.' The name has no derivation answering to etymological requirements, inasmuch as Súfíism is too exalted to have any genus from which it might be derived. ${ }^{8}$

But some decades before al-Hujwiri indicated the definition of Sufi, Islamic mysticism had already developed into a system that challenged the Muslim establishment in a variety of forms. This and the subsequent developments can be traced in the history of Islamic mysticism, which can be - for heuristic reasons - divided into a number of phases, phases which seem to correspond to major socio-historical developments. This historical periodization has been gathered from academic work available on the subject, ${ }^{9}$ but is a still-debated subject, rather than presenting scholarly consensus.

According to this proposed schema, the first phase spans the period from approximately 700 to 950, when individual mysticism gradually developed in the wake of the establishment and expansion of early Muslim dynasties and empires, such as the Abbasids and Fatimids. This first phase can be said to have started with Hasan al-Basri (d. 728) and his circle who introduced, among other things, the notion of ascetic piety $(z u b d)$ as a constitutive element of early Islamic mysticism, in the peripheral garrison town of Basra which later developed into a cultural centre. A number of important ascetics followed, such as the female mystic, Rabi'a (d. 801), who later became famous for her idea of sincere love (mahabba) of God. From Basra early mystical ideas migrated to other areas such as Syria and the new capital Baghdad, where they were further developed, or encountered similar ideas in the local context. Soon Khurasan became a major centre of mysticism. ${ }^{10}$ Here Shaqiq al-Balkhi (d. 810) argued for the mystic state of abandonment into God's will (tawakkul) and is said to have described the various stages of worship. The Baghdadian al-Muhasibi (d. 837) added psychological introspection, while the Egyptian Dhu al-Nun (d. 859) introduced mystical intuitive knowledge (ma'rifa) to the terminological universe of Islamic mysticism. His Iranian colleague Sahl al-Tustari (d. 896), who migrated to Basra, elaborated upon the idea of divine light, from which derives the luminous spirit of prophet Muhammad, and encouraged the constant recollection of God (dhikr), ideas which were appropriated 
again and again in mystical history. The famous Persian thinker al-Hakim al-Tirmidhi (d. c. 910) came up with the controversial idea of the seal of sanctity or friends of God (khatm al-awliya), thereby privileging the highest spiritual successor who brings to an end the cycle of sanctity. This creative formative time phase was known for its two other great Sufis, al-Bistami (d. 875), from Khurasan, who propagated among others the concept of the passing away of the attributes of the carnal soul (fana), and the Baghdadian al-Junaid (d. 910). While the first stood for intoxication (sukr) and selfblame (malama), the latter tended to postulate the sober ( $s a b w$ ) version of the unity of God (tawhid). Both of them were considered to be models among the following generations of Sufis. They provided major ideas for the development of this first phase which found its climax in al-Hallaj's famous words ana al-haqq (I am the truth), words that cost him his life. Al-Hallaj's dramatic execution in 922 was a reflection of the tussle which had gradually emerged between representatives of shari' $a$ and tasawwuf, of lawyers (fuqaba) and religious scholars ("ulama) on the one side and mystics and gnostics (sufis and 'urafa) on the other.

This tussle evolved during the height of the Abbasid Empire, when Islamic law came to be codified, eventually leading to a certain ossification of the legal system. During this time, this first formative phase of Sufism was characterized by few rules and regulations for the mystic and his followers. Various mystical states (abwal) and spiritual stations (maqamat) were to mark the path (tariqa) ${ }^{11}$ starting with repentance, i.e. conversion to a new way of life, and through different other stations reaching gnosis ( $m a^{\prime}$ rifa), and ultimately leading to the annihilation in God ( fana). Both states and stations can be considered as vehicles for acquiring truth (haqiqa) considered as being one of the three levels of cosmic evolution - the other two being exoteric (shari ${ }^{6} a$ ) and esoteric (tariqa) respectively. In spite of this sophistication of the mystical fabric there was no institutionally binding order but only individual monasteries and groups around the Sufi masters, the shaykhs. Although the moral authority of the spiritual master was already accepted, the shaykh, the friend of God (wali Allah), was not yet bestowed with totalitarian power - this was to change in the third phase only.

Initially, tasawwuf was intellectually and socially mostly represented by artisans with individualistic tendencies without a sophisticated organizational and theoretical superstructure, which emerged only gradually. Motivated by discontent with the political and social situation around the ruling class and their legitimators, i.e. most of the orthodox scholars and jurists, it was also a movement against the establishment of legalism, which came to rule the lives of common Muslims. Outwardly tasawwuf was quietist and regressive, but inwardly it was powerful and activist: al-Hallaj's execution was a manifestation of gradually increasing Sufi visibility, a visibility that had become the symbol of anti-authoritarian and anti-orthodox public struggle.

The second phase (roughly 950-1100), set against the background of Muslim revolts and the disintegration of the Abbasid empire into many territories, eventually brought about an accommodationist approach of Sufis towards orthodoxy, as they found themselves in a position similar to the marginalization of Shi ites in Sunnite Abbasid dominated territories. This, as well as the growing impact of Persian-Shi' ite political thought on the borders of the Abbasid Empire, led to a Sufism actually incorporating many elements of Shi'ism. Thus, eschatological ideas increasingly influenced 


\section{Introduction}

the mystical fabric, especially since the doctrine of disappearance ( $g h a i b a$ ) of the 12th imam in Samarra in 878. On the other hand, there was the deliberate process of standardization and systematization of mystical ideas, such as can be gleaned from the works of Sufi apologists - most of them from Persian stock. ${ }^{12}$ However, in the wake of attempts to expel mystical and Shi'ite influences from Islamic heartland by the Sunnite Seljuks in the eleventh century, mystical activities increasingly found their way into rural areas, as well as into far-away regions such as South Asia. At the same time a standardization of mystical ideas paved the way for the integration of exoterics and esoterics. It found its culminating point in the encompassing oeuvre of the jurist, philosopher and mystic al-Ghazzali (d. 1111), in his autobiography called 'Deliverance from Error' and his major work, 'The Revival of the Sciences of Religion'. ${ }^{13}$ After a long, painful journey into introspection he propagated obedience to both the shari'a as a meaningful way to structure one's life-world, as well as the divine service of the mystics as a way to salutary knowledge of spiritual truth. Beginning to call himself reformer - mujaddid - he could synthesize so successfully and creatively, because he could build on the ideas of his intellectual and spiritual predecessors, who had produced masterpieces of early Sufi ethical thought and a whole genre of manuals of practice and spiritual courtesy (adab).

Apparently, the standardization was a conditio sine qua non for the integration of shari'a and tasawwuf. This integration, however, became most manifest in the next (third) phase: The formation and spread of the institution first of mystical groups ( $t a^{\prime}$ ifa) and then of orders (tariqa, pl. turuq) in the form of social mass organizations (1100-1300), most prominently at the peripheries of the Muslim empires. The proponents, the mystical orders and congregations, used the shrines and tombs (dargah, tekke, zawiya, ribat, ziyarat, mazar $)^{14}$ which had developed around the graves and sarcophagi of the mystics and their successors as centres of spread. The orders' tendency towards both popular piety and mystical ideas was in a way responsible for the creative interaction between alien indigenous and Muslim exogenous ideas and institutions. Through its rituals the shrine was able to make Islam accessible to the uneducated masses. It offered them vivid and clear manifestations of the divine order and integrated then into its ritualized drama, both as participants and also as patrons. $^{15}$

It was, and still is, this mysticism and its drama that provided refuge, shelter and social cohesiveness for a variety of people who wanted an alternative source of comfort within institutional affiliations - in the organized community life, such as the khanaqah and ribat, with its fraternal security and safety - particularly during the ritual periods such as the death anniversary of the shaykh (maulid; "urs) when profane time is dramatically separated from sacred time. ${ }^{16}$ Certainly, this identity was/is revived and maintained at congregations and mass events through communal actions. It is in this context that the cult of the Prophet or the legend of the messiah built around a leading person - the shaykh, murshid or pir - became as important as the use of religious symbols.

Moreover, the ritualized collective visits to the shrines connected to the operations of orders and their centres or leaders turn out to be important social events that also generate profitable earnings due to related economic transactions. The physical 
movement to these places or persons can be linked to a spiritual one, namely the elevation of a lower level of consciousness to a higher one, or, in profane terms, the ascent of a social group into another or at least a ritual and situational overcoming of individual limitations and social barriers. An egalitarian identity is being created, as the Sufi song (qawwali) proclaims the equality of all. ${ }^{17}$ Thus pilgrimage is an act of affirmation, and can, in the face of the multi-centredness of the orders, be considered a minor pilgrimage (bajj). ${ }^{18}$ A complex, sacred geography is thereby created, contesting the authority of the centre so that the certainty and authority of the centreperiphery system was/is increasingly destabilized.

Hence, in this third phase, the position of the shaykh (Persian: pir) was further refined and gradually endowed with omniscience, such as argued by Abu al-Najib al-Suhrawardi (1097-1168), the author of the first manual of Sufi discipline called Adab al-muridin (The Ettiqette of Disciplines) and who is to be distinguished from Shihab al-Din Suhrawardi Maqtul (killed 1191), the great master of illuminist thought. The chain of traditionalists or sacred genealogical link (silsila) became an established device to affiliate the shaykh to one of the first four caliphs, a trend fully developed by Abu Nu'aym al-Isfahani (d. 1038). The number of traditions which featured words attributed to God (badith qudsi), as distinguished from words of the Prophet (badith nabawi), apparently began to increase. ${ }^{19}$ These divine sayings were rather didactic in nature, concerning primarily the believer's spiritual life and his/her relationship to God. As such they were favoured by Sufis as a source of inspiration and could become a proven way to confirm the shaykh's power and enhance his moral authority. Likewise, the mystical lore and remembrance of God (dhikr) as a method to induce mystical states was sophisticated and elaborated by mystics such as Najm al-Din Kubra (1145-1220). ${ }^{20}$ These and other identity markers and rituals were most important for new, rising communities, who gradually developed into prime parent orders along khanqahs and monasteries or graves of the powerful shaykh or pir, the master of the mystical path (tariqa). Their deputies and successors (khalifas), as well as their followers and students (murids), guaranteed the spiritual continuity which permitted the orders' presentation as an unbroken chain of succession of the Prophet. ${ }^{21}$ The orders, basically named after their founders (such as Qadiriyya, Naqshbandiyya) but also connotating toponyms (Kubrawiyya, Suhrawardiyya, Chishtiyya, etc.) often were constituted by specific social groups. The orders spread out in different regions and carved their universe into spiritual territories or saintly realms (walaya or wilaya). Thus, it is the Sufi order that marked the highest political and social meaning of the Sufi movement. It is in the orders that mystical individualism established community and solidarity. ${ }^{22}$

This third phase also witnessed the collapse of Baghdad, the realm of the great Abd al-Qadir al-Jilani (d. 1166), who had reconciled traditionalist Hanbalite legalism with ecstatic mystical individualism. Furthermore, against the background of the Mongol invasion, mystical ideas were systematized and aestheticized by masters like the well-known Spanish mystic theorist Ibn 'Arabi (d. 1240), who is buried in Damascus and whose work has become a signpost and landmark. ${ }^{23}$ His ideas on the Muhammadan reality (baqiqa Muhammadiyya), the Muhammadan light (nur Mubammadi) and the concept of the perfect being (al-insan al-kamil), emanating from the archetypical 


\section{Introduction}

Prophet, culminated in the concept of 'unity of being' (wabdat al-wujud). Another prominent Sufi of this time is Jalal al-Din Rumi (d. 1273) who became particularly famous for his didactic poems, which are still being read in various circles.

In the following (fourth) phase, a first spell of institutionalization of the orders can be depicted, going hand in hand with their integration with professional groupings such as guilds and various movements of young men known as futuwwa (1300-1700), as well as the establishment of major Muslim empires in the fourteenth and fifteenth centuries. This fourth phase witnessed a further development of hierarchical concepts and a diversification of mystical practices. It also brought to light new aspects and issues for an organized communal life, which apparently were to become important in the process of empire-building. In the face of these developments, rules and discipline had to be restructured and reformed, and membership reformulated. Well-known concepts such as futuwwa, spiritual chivalry (jawanmardi) and guilds proved to be useful devices for the processes of both expansion and integration.

These concepts provided for morality and straightforwardness, but above all for masculine virtues, such as pre-Islamic norms of bravery and hospitality characterizing the socially free and unbound man $(f a t a)$. The virtues began to be associated in Sufi circles with the fourth caliph Ali through the tracing of the initiatic chain (silsila) back to him, to the extent that Ali became the fata par excellence. However, futuwwa-organizations also implied social rebels who at times were on good terms with guilds and professional associations, connections that had inventively been made use of by caliph al-Nasir (d. 1225) for the purpose of integrating Abbasid rule before its last breath. ${ }^{24}$ Gradually, orders had become so powerful that they became constitutive elements for the establishment of whole empires, such as the Ottoman and Safavid Empires, so that the ruling classes needed them for their expansion. For example, the Mughal Empire used Sufi orders for its policy of cultural integration. ${ }^{25}$ Against the background of this incorporation and subsequent bureaucratization of the orders and their spiritual and material appropriation by ruling families and dynasties in order to enforce the centralized policies of Muslim empires in the seventeenth century, a first spell of rethinking of Sufi ideas emerged in the writings and actions of scholars as disparate as Mulla Sadra (d. 1640), the most prominent philosopher of the Safavid era in Iran, and Ahmad Sirhindi (d. 1624) of India, who tried to programmatically mobilize mystical ideas for social reform. The first gave prime importance to rationality and called for a critical evaluation of Sufi teachings and philosophy, at a time when, in the Safavid Empire, Sufism in its institutional form was deprived of its public and social expressions. ${ }^{26}$ The second - the 'renewer of the Second Millennium' - stressed strict observance of shari $a,{ }^{27}$ though there were other major Sufi leaders of that time pointing out the necessity of Islamic law as well. But the case of Sirhindi gives a clue to the versatile voices of that age, when he reinterpreted the saintly idea of 'unity of being' in terms of a more prophetic concept of 'unity of experience or witnessing' (wahdat al-shubud) as a powerful Sufi message, thus empowering those who aspired to acquire agency in order to change the social fabric. ${ }^{28}$

As the three great Muslim empires witnessed their political decentralization in the eighteenth century, ${ }^{29}$ a powerful wave of Sufi rethinking seemed to have arisen in different parts of Muslim-majority areas, while in Arabia the puritan movement known 
as the Wahhabiyya was inimical to Sufism. ${ }^{30}$ This era of political, social and cultural reform marks the fifth phase, spanning roughly from 1700 to 1900. To be sure, elaborating on these developments and debates the researcher is confronted with major problems, because there were many different tendencies present at the same time in an area stretching from South East Asia to North Africa. Not all were subject to exactly the same intellectual tendencies. But some scholars have called this rethinking 'neoSufism', which was later rejected; others have coined the term 'Muhammadan Path' (Tariqa Mubammadiyya). ${ }^{31}$ It seems, however, that an important feature of this Sufi rethinking was an ethical concept according to which direct initiation became increasingly possible. This might have questioned the concept of silsila. It is true that there were a significant number of approaches that made possible a direct access to the Prophet, but the real and physical encounter with the Prophet became quite important now, through means of different mystical devices, such as refined remembrance of God (dhikr) and the formula of blessing upon the Prophet (tasliya) in particular. At the same time, multi-layered affiliations of individual and group identity which had been evident as early as in the fourteenth century, seem to have become even more popular. ${ }^{32}$ This can be seen in simultaneous memberships of multiple Sufi orders with the changing and competing involvement of different loyalties and affiliations. One may contend that the underlying postulate of appropriating God's message individually and freely through the revealed text implied the emancipation of the self from immediate and direct ties of authority. It also opened the way for the reconstruction of Islamic society by laypersons, in many cases justified by the iteration of an original historical model, referring to the early 'Muhammadan' time. This seemed to be ijtihad in the widest sense, and it is most likely that the past that was referred to seemed not to be perceived as an era of heroism that would return, but as a political and social utopia, which needed individual efforts in order to be lived and translated into reality. Thus, the act of memory could be energized through a mood of powerful expectation. Needless to say, this approach would stand in contrast to traditionally bound compliance with state law and thus the ties to authority - taqlid, as was the case with the major part of the imperial service elites. The social basis of the receptivity to this ethical concept was, as it seems, primarily to be found among the newly emerging urban social formations of traders and businessmen. They were able to establish themselves in the wake of the expanding world market on the one hand, and political instability of the Muslim empires on the other, along the borders of the newly established princely territorial states that had evolved in several regions in the beginning of the eighteenth century. Soon, the ethical concept of the 'Muhammadan $P a t b$ ' was translated into political action, originally in reaction to changes in land rights by the new princely territorial states and then gradually turned against European trade and colonial intrusion, as can be seen in the activities of numerous orders evolving in the nineteenth century. Likewise, these orders called for religious and social reforms, primarily among agrarian societies and nomadic and semi-nomadic tribes informed by egalitarian ethos. Eventually, certain orders contrasting with urban trends rallied against colonial expansion; examples are the Sanusiyya, Tijaniyya, Mirghaniyya and Naqshbandiyya. Some of them merged with anti-colonial Mahdist movements and called for warfare (jihad) against the infidel enemy. ${ }^{33}$ 


\section{Introduction}

Another spell of the institutionalization of Islamic mysticism began around 1900. This sixth phase, it can be argued, was basically informed by anti-colonial, national and nationalistic movements, in which mystical orders provided prime channels for Muslim cultural articulations and mobilization. However, these orders were increasingly contested by the emerging urban Islamic reform movements, certain panIslamic and Salafi endeavours and eventually by the ideologized Islamic movements such as the Ikhwan al-Muslimin and Jama'at-i Islami. The endeavours of men like Jamal al-Din al-Afghani (d. 1897), Rashid Rida (d. 1935), Hasan al-Banna (d. 1949) and Abu al-Ala Maududi (d. 1979) are cases in point. ${ }^{34}$ Their deliberate silencing and obliteration of Sufism was programmatic, since a victory over esoterism was to render them into the sole agents of Islam, regardless of the Salafis' and Islamicists' contesting opinions. Hence, many Muslim activists and intellectuals even now stigmatize mystical ideas and folk-religious practices as being un-Islamic, opining that they were inserted into Islam by charlatans and spiritual delinquents who were then uncritically followed by the ignorant masses. ${ }^{35}$

After World War II and in the light of the foundation of new nation-states, Sufi orders were deliberately marginalized from the ideological and political centre, among other developments by the appropriation of their economic base via the nationalization of religious endowments (waqf, pl. auqaf). But along this decline, mainly initiated by state agents and representatives of political Islam, there is also a continuity of organized Sufism, such as in many areas of Africa. Corresponding with contemporary Islamic revival since the 1970s, we witness resurgent Sufism, politically, such as was the case of Ayatullah Khumaini, who considered Sufi spirituality in terms of 'irfan as private speculative mysticism distinct from Sufism as a social and institutional movement crucial for his Islamic system. Indeed, his interest in the philosophy of Ibn 'Arabi did not prevent him from intimidating and suppressing Iranian Sufi leaders, some of whom have gone into exile. Sufism also witnessed a revival apolitically in areas as diverse as Egypt or the now defunct Soviet Union. ${ }^{36}$

More recently with migration and rapid social changes, Sufism and its institutions once again have been envisaging most fascinating and complex systems of solidarity and commonality when they make conscious attempts at reconstructing or reinventing Sufi tradition based on and recurring to its long and multifarious evolution with a variety of ideas and methods, organizations and institutions. Additionally, this seventh phase is marked by individual mystics using esoteric ideas designed for new social formations, particularly in the Muslim post-colonial diaspora. This all is happening in spite of the prevalent worldwide Wahhabi anti-Sufi influence in recent years, particularly by means of the Islamic World League, established in Mecca in 1962. The versatile development of the diasporic mysticism and its theoretical, institutional and organizational patterns seems to have materialized because contemporary Sufism is able to invoke an all-encompassing history and rich heritage of ideas and institutional building processes, as sketched out above, and as will be discussed in a number of chapters.

The present volume is primarily concerned with this seventh phase of Sufism, including organized and unorganized Sufism, representing orders and folk-religious practices that have formed the alternative, or rather complementary, sources of social 
and intellectual identity and institution-building processes to what is commonly known as orthodox mainstream Islam. This is even more the case, since diasporic Sufi orders may be seen as part of the Muslim global diaspora, providing for yet new identities and solidarity systems and making meaningful the diasporic situation for a variety of new social formations by expanding its semantics.

Some of the ideas and developments briefly outlined above echo in the contributions to this book. We saw that Sufism in the West, in contrast to Islamic orthodoxy, has thus far been relatively marginal in the public sphere, in spite of the fact that popular practices and Sufi traditions have been present in one way or the other. This is especially the case with the influx of immigrant Muslims to the USA and in Europe from the mid 1970 s onwards, when they started reproducing their indigenous religious, cultural and social contexts in an alien and sometimes hostile environment.

In the light of recent social and political developments in Muslim-majority countries in general and among diversified Muslim minorities in the West in particular, this book elaborates the ideas and institutions of organized Sufism and folk-religious practices which provide for a diasporic post-modern pluralistic situation. Nearly all chapters discuss the brief history of the respective Sufis, orders and movements they introduce, their social base, their ways of organization and institutionalization, and respective hierarchization, as well as their recruitment patterns in new environments, sometimes in comparative perspective to their countries of origin. The ways, means and channels of disseminating ideas, such as ritual, charisma, organization, and the reasons for, and plausibility of, their popularity among certain social groups, as well as the nature of their affiliations with the countries of their origin are touched upon. Likewise, their economic activities are highlighted.

\section{The contributions}

Concentrating on the major genres of literary productions among Western Sufi movements, Marcia Hermansen distinguishes Sufi movements in the West into 'hybrids', 'perennials' and 'transplants'. 'Hybrids' belong to those movements that show close ties to an Islamic source and content, embedded in a non-Islamic framework. These movements attract both immigrants and people born or socialized in the new environment. 'Perennials' generally represent groups who are close to the idea that truth forms the base of all religions. Still, they are divided among each other into perennialist, universalist or traditionalist positions. Examples of perennial movements are 'The Sufi Order International' of Pir Vilayat Khan and his son Zia Inayat Khan, the 'Society for Sufi Studies' of Idries Shah (1924-1996) and the 'Tradition' of his brother Omar Ali Shah. 'Transplants' connote groups who rather remain among themselves without adapting themselves to the new environment.

By using the word 'literary' Hermansen refers to a wide range of sources, including all possible and diverse genres, such as transcribed lectures, hagiography, poetry, Sufi 'Op-Ed' pieces, allegories, quest novels, biographies and autobiographies, but also polemics. The literature produced by these movements reflects its vast diversity. The major themes of these genres are transformation, travel and Sufi psychology. The first theme mainly deals with telling the stories about the gradual way of conversion. 


\section{Introduction}

Conversion does not only mean becoming a formal practising Muslim. Many stages of conversion and transformation can be observed, for example, simply by joining a Sufi movement without actually becoming a Muslim. The second theme is concerned with the different travels and journeys and how they can be used for purifying reasons. It concentrates on transnationalism, a phenomenon that is seeking to overcome questions of national identity. The third theme, Sufi psychology, sheds light on how Islamic and contemporary psychological Western discourses interrelate with each other. Its main contents illustrate transformation and healing.

Over and above all, Western Sufi literature enables a synthesis of different perceptions, Islamic, Western, traditional or modern identities, through their wide range of themes and genres. Moreover they reopen discussions about identity, authority and location. Hence,

Members of Western Sufi orders are constantly negotiating traditional symbols and methods with their experiences as contemporary individuals from or living in Western environments. Some Sufi teachers negotiate these tensions by explaining why certain methods are chosen over others and how correspondences exist among therapeutic/scientific approaches and various spiritual paths. (Hermansen, p. 53)

Similarly, Leonard Lewisohn's contribution shows the immense flexibility of Sufi orders:

The life of the spirit is only one, albeit the central, part of the Sufi's life, but the Sufi lives like every other member of society subjected to the ills, malaise and profanation, as well as the well-being, prosperity and re-enchantment of the community. Consequently, the spiritual attitudes of Sufis are not only not independent from socio-political concerns and events, but are often causally influenced by them in a very direct manner. (p. 163)

Showing the development of the Ni'matu'llahi Sufi Order, founded by Shah Ni'matu'llah (d. 834/1431) in Iran, the chapter shows how Western society as a new environment has created a new cultural expression of traditional Sufi doctrines. After giving a brief historical overview about the origins of the Sufi order, the author turns to the current head of the order, Dr Javad Nurbakhsh, who immigrated to the USA in 1979, and set up several khanaqahs in the USA and in Britain. Followed by an overall extension of khanaqahs in several countries outside Iran, the total number nowadays comprises 3600 outside Iran. Dr Nurbakhsh heads twelve shaykhs, who are entrusted with the task to initiate new followers. Below the shaykhs, other people function in the hierarchy, such as directors, khanaqab managers, stewards and serving dervishes, who conduct a number of tasks. In the process of adjusting to the West several new implements were adopted, such as changing methods of communication. Moving beyond the prevalent method of exchanging information in Iran by word of mouth, they now instead use flyers or the Internet for spreading messages. Renaming Western initiates and changing the importance of following the shari'a, which in the 
western context becomes an individual matter, are other important changes. Even the gender relations in Iran and the West differ enormously from each other. While in Iran a high level of gender segregation can be observed, in the West, veiling, separation or any specific dress code are not compulsory. The ethnic and social composition also varies from khanaqah to khanaqah, but the pattern changed after 1985, when refugees were able to flee Iran. The backgrounds of the followers also encompass a wide range in terms of class, background or profession, but the search for spirituality and consolation in the exile serves as a commonality, based in Persian culture. The $\mathrm{Ni}$ 'matu'llahi is also present over the Internet, providing the user with information about Sufism in general, the order and the spiritual leader and his publications. A huge amount of literature has been produced both in Persian and in English, mainly focusing on practices, traditions, inventions, Persian cultural heritage and its relation to Sufism and Islam, as well as volumes on Sufi gnosis. The idea that the order specifically follows modern and secular values, such as nationalism, is reflected in the fact that they emphasize Persian culture and national mythologies. But at the end their main goal lies in the spiritual source of the Ni'matu'llahi teachings. 'The One, the unborn, the undying, knows neither East nor West' (Lewisohn, p. 64).

The evolution of the Naqshbandi-Mujaddidi in Germany, as studied by Gerdien Jonker, shows remarkable resemblance to the Ni'matu'llahiyya. The author argues that Turkish Muslim organizations in Germany, such as Milli Gorüş, Nurçu and Sulaymançi amount to Sufic lay communities, which maintain Sufic devotion by reconcentrating on 'worldly religious aims' and hardly deal with discourses about devotion.

The 'modern organization with a spiritual connection' that has been created is a reaction to Turkish forced secularization. In the eyes of these Muslim practioners, the political event was catastrophic because it did away with all spiritual values and methods to obtain grace. Migration brought this response to Europe before it was properly institutionalized, and it is the Western European framework that left its imprint on the present organizational shape. Its result I have termed the Sufic lay community. (Jonker, p. 183)

After a historical overview of the existence of the Sulaymançi $d a^{\prime} w a$ organization, the chapter explains the structure of the organization, which shows features characterizing a lay community. First the religious proficiency does not depend on shaykhs and theologians or a charismatic authority. Therefore the community spawns its own staff. The role of the shaykh is changed into missionary activist. Second, lay communities are a modern phenomenon, because they are inspired by the idea that society can be renewed. Thus, the members, who are devoted believers, try to spread the divine message by means of books or religious education; a matter they consider to be a worldly duty. Third, the quest for spirituality seemingly no longer remains at the centre, although it is considered to be influential and essential for maintaining the organization. A collective approach including the aim of achieving divine grace replaces the former hierarchical approach towards spirituality based on a spiritual leader. Fourth, new fears of becoming a secular organization have been caused because of the shift from spiritual to worldly grounds and from a hierarchical transmission of 


\section{Introduction}

knowledge to that which is accessible to all who aspire for it. To enhance solidarity, dhikr and the imitatio Muhammadi are mainly performed in groups, and thus it is not the individual who achieves the 'spiritual connection', but the whole organization. In pursuing these goals for three generations, the organization, which emerged in the context of modernity and as a reaction to secularization, has adapted itself to the permanently changing environment in Western Europe by translating its teachings into European languages. The outcome is a lay community, which certainly represents modern ideas.

The shifting and changing of central Sufic practices and methods, ideas and organizational patterns can be envisaged in the next three chapters, which highlight the transnational levels of contemporary Sufism in the West. Gisela Webb considers this development in terms of waves. Her essay pays attention to Bawa Muhaiyaddeen and his fellowship and how they affected and contributed to the discourse about Islam and Sufism in a globalized societal order. According to the author, Sufism came to the USA in three stages. The first wave, starting in the 1920s, was based on 'oriental knowledge'. This wave brought Sufis to the USA in order to bring their teachings to a part of the world where presumably hardly any spirituality could be found. The second wave occurred during the 1960s and 1970s, and was marked by a revival of Muslims' lost legacy and search for spirituality among the Americans. The third wave's main characteristic is the ongoing engagement with issues of peace, communication and globalization. The explanation of the third wave is reflected by means of the Bawa Muhaiyaddeen Fellowship, which had its origins in the 1970s in Philadelphia, focusing primarily on universal spirituality. But it became more closely identified with normative Islam during the 1980s and 1990s. Although tensions signified the Sufi/Islamic identity, the fellowship was able to establish an attractive environment for the entire multi-ethnic Muslim diaspora of the USA. Moreover, they were able to unite a diversity of interpretations about Sufism and its relation to Islam, to bring people of perennial, hybrid or non-Sufi Muslim background together and to contribute to an establishment of a long-lasting community. The founder, Muhammad Raheem Bawa Muhaiyaddeen, was the central figure who became an important mediator of Sufi legacy to the USA.

The Fellowship entails three different orientations. First are those who merely follow Bawa's teachings, while the second are those who attend the mosque regularly and exercise non-Sufi Islamic practices. The third combines both these orientations. Due to a symbolic shift towards Islam by Bawa Muhaiyaddeen through building a mosque, the Fellowship involved itself in an Islamic-Sufi dialogue. After Bawa's death in 1986 no further shaykhs were appointed. Until now, two imams who lead the Friday prayers were instructed by him. Next to setting up a mosque, Bawa provided the community with a farm, for three different purposes; firstly as a location for the community, secondly as a burial site for Muslims and thirdly as a tomb (mazar) for himself. This locality enabled other group members from different ethnic origins, who did not even know Bawa, to follow their local cultural traditions and perform local practices with which they were familiar in their homeland. Over and above this the Fellowship represents an important community concerned about the public discourse on Islam in the American public, especially after 9/11. It has managed to 
establish a ground on which Muslims and non-Muslims can interact without being prejudiced. Hence 'Bawa Muhaiyaddeen can be seen as a twentieth-century example of the tradition of the popular Sufi teacher of South Asia, who taught the mystical dimensions of Islam to regions well-beyond the geographical origins of Islam' (Webb, p. 98).

The transnationalism as propagated by the Haqqaniyya is, however, different from the inclusivist Bawa Muhaiyaddeen Fellowship because it focuses on other issues, as discussed by David Damrel: 'The Haqqani order expresses a public agenda in the Americas in a number of places: it is simply to promote Islam. To this end, the order has created several affiliated organizations, each dedicated to particular types of $d a^{\prime} w a-$ related activities' (p. 118). Looking at the Naqshbandi-Haqqani order in North America, his contribution highlights their history and status as well as their core activities inside the order and towards the public. It is argued that these Naqshbandis maintain four main characteristics. Firstly, they follow a strict Sunni orientation; secondly, they stress the importance of the shari a and Sunna; thirdly, they follow their tradition of engaging themselves in social and political activities; and fourthly, they do not hesitate to challenge state authorities to abide to religion. The leader of the Naqshbandi-Haqqani order in the USA is Shaykh Muhammad Hisham Kabbani, a khalifa and son-in-law of Shaykh Nizam Adil al-Qibrusi al-Haqqani al-Naqshbandi, who represents the 'grand-shaykb' of the current order. Meanwhile a large network has been established, resulting in a 'Sufi religious enterprise'.

The activities of the order are divided into two sections. The first is the public section, while the second deals with the teachings inside the order. In public activities, the order presents itself in four non-profit organizations: the first is represented by the order itself. The second one is the As-Sunna Foundation of America (ASFA), mainly providing religious education to Muslims and establishing links to other Islamic institutions of learning, for example al-Azhar in Cairo. The third one is the Kamilat Muslim Women's organization, founded in 1997, particularly dealing with domestic issues, such as family, health, education and marriage. The fourth one is the Islamic Supreme Council of America (ISCA). The ISCA, having their office in Washington D.C., is probably the most apparent organization, since it engages itself in political matters, thereby pursuing two main goals. The first one focuses on American Muslim communities in order to provide them with a 'proper Islamic lifestyle', the second aims to enlighten American non-Muslims on 'a corrective vision of what Islam is'. Furthermore, the Haqqaniyya does not hesitate to criticize other Muslim organizations. As a consequence they were marginalized and estranged from Muslim communities in America. Nowadays, the order has started to increasingly involve in engaging American converts.

The internal affairs can be delineated in three points that show the Haqqanis' directions of instruction. The first point is the spreading of teachings via the Internet, thus creating a large virtual community. The second is the idea of millennialism, a theme that covered an enormous part of the teachings during the last three decades. The third point is the instrumentalization of issues of the modern world for spiritual teachings, such as foot-and-mouth disease, the death of Princess Diana or the Y2K excitement. The efforts made for directing themselves to the centre of representing 


\section{Introduction}

mainstream Islam and expressing sharp criticism against other Muslim organizations led the Haqqanis to a position of alienation. The question remains whether they will be able to keep hold of the order's structure in the long run.

Indeed, transnationalism comes back to this order only partially because it concentrates primarily on the shaykh, as shown by Jorgen Nielsen, Mustafa Draper and Galina Yemelianova:

Traditionally, a Sufi tariqa existed primarily as a local group, adapting to and taking on the character of the locality in which it was integrated. [...] The traditional nature of the Haqqanis is evident both in the enormous local variety and in the central esteem in which Shaykh Nazim is held. [...] As we have observed around the visits of Shaykh Nazim to Britain and Lebanon, the tariqa only fully exists where Shaykh Nazim is. (p. 113)

Drawing information from a fieldwork conducted in three different countries, in Dagestan, Lebanon and Britain, the essay focuses on the Haqqani tariqa, whose origins go back to a branch of the Naqshbandiyya in Dagestan. These three different locations were selected in order to keep certain ties to the tariqa and provide different situations and surroundings. Dagestan has been chosen because of the tariqa's origins, Lebanon because it represents the first location that offered a solid base before further orientation to the West, and Britain because the tariqa had its first base in the West there. It is shown how communities, whose focus is transcendent, acquire diversity by adapting to a new environment, and how they interact on a transnational level. On the other hand, it is interesting to see how the shaykh himself tried to contextualize the tariqa within a new framework without losing its traditional elements and its identity.

With the help of the three locations, three different environments are analysed, showing different cultural and political situations. In Britain the tariqa attracted followers from different regions, mostly being converts or of South Asian origin, who set up local groups outside London. In Lebanon the tariqa was marginalized due to different reasons, such as a comparatively little number of adherents, the shaykh's concentration on spreading the tariqa in the West, a relatively low level of tariqa traditions and attacks of the salafis and the Muslim Brotherhood on Shaykh Nazim because of his religious teachings. In Dagestan the situation has been shaped through Soviet policy, the various Islamic local traditions and ethnic diversity. However, an exact number of adherents could not be stated in any of the countries. The authors' conclusion describes the membership in three circles. Those who belong to the inner circle, the murids, regularly participate in dhikrs and are frequently in contact with the shaykh. The second circle attends sessions occasionally. The third one simply sees the shaykh as a spiritual guide.

Two more themes connected with the tariqa show its flexibility and its relations within the network, the relations to political authorities and the millennium theme. Through its political statements the tariqa got into a lot of trouble, especially in Lebanon and Dagestan, when it declared most Muslim organizations a threat to US security. The millennium discourse was mainly spread in Britain and Lebanon 
through the Internet, but was absent in Dagestan. This shows how patchy the communication among the network was. Even though the shaykh used the prevalent methods of travelling, texts, audio- and videotapes, the 'locals' living in Dagestan were excluded from most of the network. Two pertinent questions are asked at this juncture. Can one really speak of a 'community' in the light of inequalities within the network, and is it really transnational? The answers to these questions are illustrated by the shaykh's person himself. The community only exists around his presence during visits. The same is true for transnationality, which is closely tied to the shaykh. Without his presence and the mere existence only in society the tariqa becomes translocal.

According to Roger Ballard,

Britain's Pakistani Muslim population is now rather more than three quarters of a million strong. The more firmly such migrants - as well as their overseas-born offspring - have established themselves in their new homes, the more comprehensively they have begun to reconstitute almost every aspect of their social, cultural and religious heritage. The results are now plain to see: a multitude of self-sustaining ethnic colonies have by now sprung to life within the heart of most British cities. (p. 175)

He focuses on the interactions and interdependencies of Sufism and orthodoxy and on how Islam can be faced as a living and lived religion, because 'Sufi spiritualism is as intrinsic to the Islamic tradition as is the legalism of the "ulama" (p. 168). However, Sufism is not to be equated with popular Islam, rather, the 'spiritual adepts who are wholeheartedly committed to intense levels of spiritual practice' (p. 168). Aspects of these Islamic and cultural traditions from the homeland have been reproduced in the diaspora, three themes being most important. First, the re-establishment of different local cults; second, the reshaping, changing and transformation of these cults; and third, the challenges addressed to the cultural heritage. The first generation of migrants, it is argued, was marked by social and cultural renunciation. But when the first migrations resulted in a long-phase presence of migrants in Britain, entailing permanently increasing numbers of immigrants, they started reconstructing their own social, cultural and religious institutions and practices. The construction of mosques, thus, served not only the purpose of collective praying, but also as a place of socializing with other Muslims living in Britain. Inevitably linked to the economic recession in Britain, many migrant workers became unemployed. It is in this context that the established mosques received further significance, when listed as charity institutions. Subsequently, the re-emergence of pirs and local cults was closely tied to the family reunions in the 1970s. It is emphasized that all processes of re-establishing local cults are by no means the consequence of a fixed traditionalism, but are due to the complexity and diversity of challenges the immigrants have to face while living in a new environment. Therefore, they required their own sources of psychological and spiritual support they were familiar with.

The second British-born generation tends to reject its parents' traditional practices, because these practices can neither offer it solutions in a British environment, nor help it 


\section{Introduction}

to identify itself as Muslim. This dilemma causes neo-revivalist movements to become a magnet for a significant number of followers. Still, these movements, despite being able to attract attention and gain followers, are not able to offer their followers a wider range of information about their origins and their cultural, religious and linguistic heritage. Consequently, the author argues, the older movements will reassert, because once they start reaffirming themselves and their origins they might realize that the neo-revivalist movements are not in a position to get a hold of the entirety of resources available.

These tensions between Sufi movements and folk-religious practices on the one hand, and neo-revivalist movements and the call for orthodoxy on the other, is highlighted by Ron Geaves:

Increasingly, Muslims loyal to the tariqas have become concerned that the combination of urban environments, western education and the secular ethos will provide the conditions in which they will lose their children either to the attractions of the pursuit of material pleasures or to recruitment by the betterorganized reform movements. (p. 147)

Muslims living in Britain, mainly from Pakistan and Bangladesh, draw on practices and beliefs that are connected to tradition rather than to orthodoxy. In the last twenty years, especially, many transplantations and developments of branches of Sufi tariqas can be seen. Still, Sufism showed a quite slow development due to three reasons. Firstly, migration - the new, small immigrant community could not fully represent its Muslim diversity. Thus, reform movements, such as the Deobandis, could gain ground. Secondly, there were tensions between the urban imams and the predominantly rural congregations at mosques, and thirdly, a lack of local shrines. Consequently, local versions of Islam did not develop in Britain; rather, believers related on journeys back home. Reform movements, which arrived in Britain through migration, such as the Deobandis and the Jama'at-i Islami, used these tensions to work against traditional Islam and Sufism. However, the Deobandis and their religious and ethnic discourses focusing on the subcontinent were not able to attract a larger number of youths among British Muslims, who were looking for solutions to being a Muslim in Britain.

Organizations such as Jama'at-i Islami were able to catch the attention of these youths by providing them with a new identity concerning Islam and using it as their ideology, thereby overcoming ethnic or national boundaries. Other groups criticizing Sufi practices are the Hizb ut-Tahrir who identify themselves with the Salafis, and the Wahhabis. Even though the Barelwis, whose version of Islam evolves around local customs, are large in number, they were not able to organize themselves. It was only in the 1970s and 1980s that a united Barelwi identity evolved, when a respectable number of shaykhs and pirs arrived in Britain, followed by construction of mosques and production of literature rejecting the reform movements' critique. But the danger of losing youth to the better-organized reform movements, due to unemployment, recession and a lack of opportunities, has given way to yet new organizations and movements, such as the Idara Minhaj ul-Qur'an or the Haqqani-Naqshbandi orders. They are trying to provide people not only with an ideological and organizational 
foundation for traditional beliefs, adapted to British context, but also with alternatives to the reform movements.

Yet, at the local level, the microcosm of Sufic and popular Islamic traditions show remarkably different, indeed, versatile ways of seeking the path, as elaborated by Pnina Werbner:

The social heterogeneity of diasporas, their internal complexity, is a central feature of all established diasporas. This is particularly so in the case of South Asian Muslims who orient themselves towards a global Islam while practising a peculiarly Pakistani or South Asian version of that Islam. (p. 129)

By examining three different ways of being a Sufi in Britain, Werbner's essay substantiates the transnational character of Sufi cults, though in Britain a large number of Pakistani Sufi cults centre on a local khalifa or pir and maintain close ties to the origins in Pakistan. These cults mostly constitute networks inside Britain, especially in major cities and cult centres in Pakistan.

Three different life paths of becoming and being a Sufi, belonging to the same Sufi order in Britain, show this tendency in detail. The personalities of three khalifas are centred on Shaykh Zindapir, who died in 1999 in the North Western Frontier Provinces, and who belonged to the Naqshbandiyya Ghamkoliyya. The cult he followed displayed in many terms orthodox elements. Pictures, portraits and biographies of him were forbidden.

It is further argued that Pakistani communities in Britain and communities in general are not only shaped by religious or ethnic reasons. They rather share their orientation in time and space, for example by joining different circles, such as poetry readings or recitations, religious discussions or political gatherings. This shows two main features of all diasporas, namely, internal complexity and social heterogeneity. Even among the Sufi cults many distinctive characteristics can be observed: not all groups catch the attention of British-born followers. They mostly consist of endogamous groups from the subcontinent. In contrast, Sufi groups show a certain level of heterodoxy by focusing on dhikr and meditation. On the one hand, they invent new traditions; on the other, they keep on treading in the Salafi direction. The gender relationships differ from group to group. The milieu of followers is predominantly South Asian, the spoken language among these groups is mainly Urdu. However, their members, many of them British-born educated Muslims, consider themselves to be open-minded towards other faiths and nationalities. At the same time all leading figures put great emphasis on faith healing and amulet writing.

Even among a single Sufi cult, three different ways of being a Sufi can be envisaged. Hence, all the three khalifas of Shaykh Zindapir show different backgrounds, motivations, emotions and identifications towards their shaykh in Pakistan. The first one was able to build up a religious empire in Britain, achieving a charitable status, then extended the regional cult around Shaykh Zindapir from Pakistan to England and gained charismatic authority. He became a significant figure for Barelwis in England. The second one founded a branch of the order in Manchester. He tried to achieve knowledge of the transcendence, but remained disappointed, because his 
shaykh was not able to transmit that kind of knowledge to him. His approach was rather intellectual, while he relied on Urdu sources, such as the translated letters of Ahmad Sirhindi, Naqshbandi texts and discussions with other khalifas. The third one obtained a research post at a British university, and maintained close ties with the shaykh and to God, which was always linked with his fortune while living in Britain.

\section{Major themes of diasporic Sufism}

In the diverse contributions to this volume, a number of unifying threads may be discerned. Some of the common themes that have come to ready attention in this volume are: the process of religious construction, mystical as well as historical; the complexity and multiplicity of identity; the problems of localization and symbolic representation; the dynamics of conflict and that of reciprocities. It is towards these common themes that we turn our attention now. ${ }^{37}$

\section{Construction of religious history}

Taking into account the plural structures of competitive religious or Islamic systems, as is the case of Sufism in the West, some contributors have interrogated the process of construction and establishment of master narratives of a dominant normative history as against divergent 'sectarian histories'. Hence, the ambivalent role of memory and canon, as well as the narration of the history as a conscious and noninnocent process for solidarity and identity needs to be taken into account. The critical evaluation of this process interrogates the validity of historical narrative and, connected to that, tradition, which is equally important for religious and Sufi legitimacy. Instead of regarding tradition as a firm and authoritative part of religious and cultural identity, the chapters bring out the limitations of what is being negotiated as tradition.

The role of Sufis in the West highlights a major example of contested tradition, when Muslim immigrants recreate demands and desires that were to be met by newly evolving local holy men or their deputies (khalifas). However, this lived and reproduced Islam of the first migrant generation gradually came under severe criticism by the second generation with the appearance of new Muslim youth cultures. They tended to take refuge in neo-orthodoxy and so-called Wahhabi or Islamist movements. Their scripturalist approach provides Western-born Muslim children with the 'Islamically' legitimated desire for differentiation, on the one hand towards their parents - which can be read in terms of generational conflict - as well as differentia-

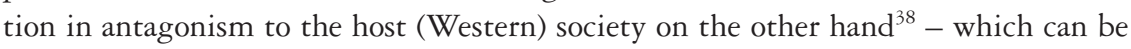
read in terms of self-exoticization. As has been argued elsewhere, Islamist discourse has become a powerful emancipative tool for youth - against the traditional cultural baggage of their parents both in Muslim-majority countries and in diaspora contexts. Young Muslim women, in particular, increasingly use the veil to symbolize their Muslim identity, and also to transform feminist critique into an Islamic one. ${ }^{39}$ However, due to the relative soberness and exclusivity of orthodoxy and scripturalism, and because of the new rising self-statement of evolving diasporic Sufi movements, 
the Muslim traditions of the first generation have learned their lessons, as it were. Their children have stimulated a concerted counter-attack in which their Muslimhood hopes to reclaim the loyalty of future Muslim generations in the West, at times in a polemic and apocalyptic way - a clash that certainly involves the competition and contest over both the interpretation of symbols and control of the institutions, formal and informal, that produce and sustain them'. ${ }^{40}$ Some of the contributors to this volume such as Ron Geaves, Roger Ballard and Pnina Werbner explore these developments lucidly, showing the versatile forms that they are taking in reconstructing master narratives and tradition and the huge problems that they will have to surmount. Hence, it is only recently that Sufism has become a vocal and considerable force among Muslims in the West, not the least because of its deliberate use of public media such as the Internet, through which Sufi movements can share 'spiritual' communication in a deterritorialized and retraditionalized way. These tendencies are comparable to the phenomenon of Internet fatwas among immigrant orthodox Islamic groups, ${ }^{41}$ as can be gleaned from the contributions such as by Jorgen Nielsen et al. and David Damrel.

At the same time, elite movements or orders such as the Sulaymançis, which transformed into an organization of the Muslim Turkish lay community in Germany, target primarily professional classes when reading out the letters of the Indian Naqshbandi reformer Ahmad Sirhindi, who stressed the direct, unmediated contact with the shaykh and his divine grace. To appeal to these classes they tend to create and reinvent new cults and narratives, i.e. a new history, thereby departing from the original and traditional Sufi path, as has been shown by Gerdien Jonker. Others even try to integrate more literalist, orthodox, or intellectual aspects with more popular, i.e. heterodox, ones. The adjustments of the Iranian Ni'matu'llahis are a case in point. Since the late 1970s, they have spread into the West, which they conceptualize as an exile, implying an ultimate return - as portrayed by Leonard Lewisohn. The Western migration of this order - considered to be its third diaspora - and its versatile approaches to religious diversity show clearly that the Ni'matu'llahis, in the process of diffusion, have constantly and successfully been expanding the semantics of diaspora. They have been re-presenting gender issues and Sufi ideas in diasporically accessible and vernacular terms, as well as making use of reciprocal translations of a variety of symbols and terms. All that provides for the ability of action on different social levels, ${ }^{42}$ thereby creating 'sacred nationalism', which might negate the transcendental aspects but at the same time endows the nation with a transcendental quality, and which reifies the notion of exile.

Within this process of diffusion, however, responses of religious traditions in general and Sufism in particular stretch from orthodoxy to the most liberal manifestations. The former can be recalled in the diasporic mystical orders' advocating strict adherence to principles set up by their founders and their followers. The iteration of a mythical original establishment shows the enormous potential and meaning of these social and spiritual formations for identity-forming processes. Liberalization may, in fact, be traced in the orders' changing their forms and content when they refrain from gender segregation or call upon converts to keep their Christian names, as the Ni'matu'llahis have done. This reflects new dimensions of multi-ethnic and 


\section{Introduction}

multi-professional base of the migrants as well as the transmuted orders in a diasporic setting.

\section{The question of identity}

Connected with the issue of the construction and reconstruction of history and tradition is the question of the identity of members of Sufi movements and orders, firstly from the external perspective, that is, the identification of the other, and secondly, from the internal perspective, that is, self-identification. In this context composite identity is understood as a procedure in the argument between self-reference and reference of the other. Basically, identity can be changed without major difficulty according to context and can therefore be described as situational, multiple or corporate. It is open rather than closed. Hence, identity is not a given but rather a process of becoming, which matters in context. This is particularly true in the case of cultural encounter, reciprocity and oscillation between different subjects that necessarily lead to a cultural multi-dimensionality and which can shift and extend predetermined limits and standardization. Consequently, normative and hegemonic identity constructions are being shifted, extended and displaced exactly at these frictional points. Therefore, it seems that the most creative forms of cultural identity emerge at the margins of the lived realities of collectivities, and are manifest in multiple affiliations and loyalties and hence in code- and identity-switching. This is even more the case, since minority and majority mutually conceptualize each other and therefore always form a complex cultural ensemble. The Sufi orders and movements in diaspora are good examples for this interaction, for they provide exactly the religious pluralistic potential required.

Most radically, as argued by some diaspora movements, Islamic mysticism does not even require a Muslim identity, as the case of the Bawa Muhaiyaddeen Fellowship studied by Gisela Webb. Pnina Werbner shows in the British context how multiple tariqa-affiliation opens up new patterns of loyalty enabling the actors to operate in different contexts. Similarly, the contributions by David Damrel and Jorgen Nielsen et al. on the Haqqani movement show the intriguing dynamics and functions across communities and ethnic groups within the vast networks of a 'hybrid', transnational, Sufi order in two different contexts, the European and the American. It seems that this 'world-rejecting' order has been one of the fastest-growing and most important orders in Western Europe and North America for some time, largely due to its non-Muslim constituency, a constituency that might be looking for some alternatives to their Western status markers such as profession and wealth. In fact, this organization brings in typical American competition in order to participate on a broader level with the host society, as has also been convincingly argued by Marcia Hermansen. Thus, light is shed on missionary as well as dialogical activities of this and other innovative orders that spread worldwide, through making use of traditional as well as modern devices, for example its propagation of millenarian visions or its deliberate deterritorialization through virtual space, notably the World Wide Web. In this process of dissemination and diffusion, different - Christian and Islamic - traditions intermingle and overlap. In the case of the Haqqani order, at one point the Islamic Judgement Day 
was to take place at the end of the second Christian millennium, in the Christian year 2000 (Damrel). Similarly, among diaspora Sufis, current political and social events and even popular culture become part of mystical pedagogical techniques and are used as teaching tools. In other cases discussion circles became part of Sufi practice, augmenting or replacing $d h i k r$, as was the case of the Society of Sufi Studies of Idries Shah (Hermansen). Likewise, some diaspora Sufi orders are multi-religious in the sense that they allow non-Sufis and even non-Muslims to join, such as those studied by Webb. Also, as can be gleaned from some contributions to this volume, Sufism can be ethnically very distinctive, leading to closed ethnic networks, but depending on their contexts, they can also split and open up, as has been elaborated in Werbner's case studies.

\section{Localization and symbolic representation}

The discussions in this book also revolve around the questions of what it is that places and spaces narrate, and how places are transformed through narration or even semiotic representation. To be sure, localization of Sufism can only occur if there are movements, either through processes of migration or through new metaphorical constructs, in a public space, in which prestige and power are constantly negotiated. Contested space is explored when looking at the definition and creation of local, translocal and diasporic boundaries - such as divisions of the mystical universe in spiritual territories since by implication all Sufi orders inevitably 'territorialize' themselves, even in the virtual space of the Internet. Multi-localization and multi-vocality establish, as does the so-called 'little tradition', a very complex, multi-centred sacred geography. But the opposite possibility is also explored, namely in cases of decentralized orders characterized by placelessness or loose networks integrated only by the charisma of the spiritual leader, that often exist virtually. Such orders, through the form of a photograph or a video may create and intensify but also shift loyalties and obligations through the power of imagination, however vague this might be. For example, Hermansen, Nielsen et al. and Webb discuss the concepts of Sufi travel in the context of changing political and economic contexts of Western Sufi movements.

\section{Conflict}

Encounter and interaction also imply conflict. Competitive situations within a specific movement, between different Sufi orders or between Sufi orders and other Muslim groups can be distinguished and described, from a legal perspective, especially when a violation of legal boundaries occurs. In other instances interorder rivalries evolve, in terms of spiritual and hence material territories. However, there is also the perspective of conflict transformation, conflict management and conflict resolution, turning conflicts into creative channels of interaction. One may well distinguish between intrareligious conflicts such as stigmatization and official oppression; between interreligious conflicts such as induced from outside a system, that is, Sufis' influence on Christianity or the West; and extrareligious conflicts, such as Sufism competing with secular systems. Consequently, conflicts must not be seen as pathological social diseases, 


\section{Introduction}

or deviations only, but can be regarded as contributions to the stability and cohesion of incremental societies, whence discussions among minorities systemically unleash debates among the host societies. These various conflictual tendencies, as well as interdependencies, can be envisaged particularly in the transformation of the Sulaymançi, studied by Jonker, of the Ni'matu'llahis portrayed by Lewisohn, and the Haqqaniyya introduced by Damrel as well as by Nielsen $e t$ al.

\section{Reciprocities}

Another important common theme of a number of chapters is the reciprocity between religious communication and social acceptance on the part of the usually majoritarian and politically dominant host countries, as well as the impact of 'new' Islamic mysticism on the self-image of Western societies. Jonker suggests that the orders and movements reflect the host societies' socio-political structures and operate within their given structural boundaries, in terms of the institutional channelling theory, ${ }^{43}$ in the case of the Sulaymançi in Germany. Werbner argues that the underlying reformist approach is also of importance in another context, that of the largest diasporic Sufi order in Britain - the Naqshbandiyya. Interestingly enough, both orders have the tendency to decentralize through the activities of contesting quasikhalifas, after the demise of their leaders. While the first keeps to the structural boundaries as they are set in Germany, in the British context they seem to be more autonomous, reflecting the local political structure. The transnationality of the orders is only one ingredient in this dynamic; the other is the host society's political cul-

ture. ${ }^{44}$ Both led to schisms and eventually to new and independent organizations, and to new social formations.

Needless to say that nearly all orders and diasporic forms or religious organizations create and maintain links with their home communities/countries, links that at times can transcend prior kinship, caste or village relations in the new environment. Certainly, such cross-cutting ties extending into home communities create a consciousness of a broader and elective Muslim community. They generate a constant interaction with the places of origin and the influx of overseas newcomers. This of course leads to the reproduction of positive as well as negative developments from back home, as discussed by Werbner, Ballard and Geaves.

The implicit context of this volume is socialization and transmission of knowledge that epitomizes all these issues. This knowledge is rendered into a normative discourse through a most complex procedure of dissemination. Likewise, the historical developments and societal conditions of these movements are considered in the new, migrational environment with reference to processes of reciprocity and othering. They are ingeniously analysed through literature pertaining to gender issues, Sufi psychologies and convert literature in the contributions of Damrel, Webb, Lewisohn and Hermansen in particular.

The present book therefore shows that Sufism in general and Islamic mysticism in the West in particular provide for a vast variety of cultural articulations that interact in a diversified public sphere in post-modern and post-secular societies, not the least because of access and usage of a vast and flexible repertory. Indeed, due to its various 
and alternative modes of articulation and envisioning of Islam which is rich and appealing in terms of spirituality and culture, Sufism appeals to many Westerners. Especially in the current political atmosphere, this might create a much-needed positive impression of Muslim culture and Islamic traditions, and might therefore be supportive of the further integration of Muslims in Western societies. Whilst penetrating mainstream Western culture through these different channels and modes of articulation, Sufi immigration might have the potential to become one vehicle among others - for a more inclusive Western response to Muslims.

A case in point could be the Islamic Institute in Mannheim, Germany. Even this rather exoteric institution that works towards the integration of Muslims in Europe was informed by ideas, such as the necessity of interreligious communication, the ideal of living interreligious collectiveness and, finally and prominently, Sufism. The activists of the Institute argued that Western rationality and progress was too restrictive, because it fulfilled the theoretical or better, the ontological conditions, of one communication partner only. In contrast, Sufism is particularly suited for interreligious and intercultural harmony of different peoples and cultures in democratic pluralist societies. It was stated that Sufism was the symbol of tolerance and humanism in Islam, undogmatic, flexible and non-violent, not striving towards the establishment of a divine order. Hence, Sufism was considered to be the starting point for the adaptation of Islam, especially for a European version of Islamic practice and for a deliberate interreligious encounter. It could not only inform Islamic practice, but also support monotheistic religions in their struggle to unite and live together in harmony, within its all-encompassing philosophy. Finally, the Institute claims, one can assert that this kind of religious tolerance would effect a conflict-free adjustment of the interests of religious minorities and majorities both. ${ }^{45}$

Even if these arguments sound a bit grand, if not naive, one may appreciate the dialogical potential of Islamic mysticism for the process of integration as it is put forward even by exoteric institutions such as the Islamic Institute in Mannheim. Especially when it comes to encounters with Sufism as a potentially innovative and ingenious interacting medium, its various representatives can be seen as oscillating actors between different social languages or consciousnesses. They are separated by social differentiation or by some other factor, but nevertheless address and relate to each other in a discursive field. Here may lie the potential of Sufism, as it always has been, when its members adopted the patterns of their host environment and hence became actors of both Islamization as well as indigenization. Given the new situations of Muslim diaspora in post-modern Western societies, Sufism intellectually as well as sociologically - may therefore eventually become mainstream Islam itself due to its versatile potential, especially in the wake of what has been called the failure of political Islam world-wide. ${ }^{46}$ This proclaimed reversal of perspective from a centralized view to a multi-vocal view might bear significant effects both on what is researched and on the researchers themselves. Contemporary organized and unorganized Sufism in the West seems to have the capacity to diversify Islam, as well as to operate in different public spheres and visibilities through its rich semiotics and symbol-systems, as well as its rituals, which appeal to a variety of social strata. 


\section{Notes}

1 I wish to thank Marcia Hermansen and Carl Ernst for their valuable comments on earlier drafts of the introduction.

2 As has been discussed for instance by Richard King (1999).

3 This tendency of singularization and normatization builds on a long history of contest against Islamic mysticism. See Frederick de Jong and Bernd Radtke (1999).

4 Compare Friedrich H. Tenbruck (1993), pp. 31-67.

5 For the following see also the introductory work of Alexander Knysh (1999); also Leonard Lewisohn (1993).

6 Shah Wali Ullah's major work has been translated by Marcia Hermansen (1996).

7 Compare R. S. O'Fahey and B. Radtke (1993).

8 'Ali Ibn 'Uthman al-Jullabi al-Hujwiri: Kashf al-Mabjub. The Oldest Persian Treatise on Sufiism, transl. by R. A. Nicholson, Lahore, 1953, pp. 30-34.

9 See for instance Annemarie Schimmel (1985a); Fritz Meier (1976b), pp. 117-128; Alexander Knysh (1999); Leonard Lewisohn (ed.) (1993); Carl Ernst and Bruce Lawrence (2002).

10 The significance of this region has been discussed among others by Fritz Meier: 'Hurásán und das Ende der klassischen Sûfik', in Fritz Meier (1992), pp. 131-156; Terry Graham: 'Abu Sa'id ibn Abi'l-Khayr and the School of Khurasan', in Leonard Lewisohn (ed.) (1993), pp. 83-1366.

11 Bernd Radtke, in Ugo Bianchi (ed.) (1993), pp. 517-522, p. 521.

12 Important scholars and Sufis were al-Niffari (d. 965), al-Makki (d. 996), al-Sulami (d. 1021), Abu Sa'id (d. 1049), al-Qushairi (d. 1072) and al-Hujwiri (d. 1071). See Muhammad ibn 'Abd al-Jabbar al-Niffari: The 'Mawaqif' and 'Mukhatabat' ... with other fragments, ed. and transl. by A. J. Arberry (1935); Richard Gramlich (1992); Franz Taeschner (1953); Fritz Meier (1976a); Abu Nasr al-Sarraj: Kitab al-luma' fi'l-tasawwuf, ed. Reynold Alleyne Nicholson, in: E. J. W. Gibb Memorial Series, 22, 1914; Richard Gramlich (1989, 1990); al-Hujwiri: Kashf al-Mahjub.

13 Compare Imam al-Ghazali/R. J. McCarthy (2000); for al-Ghazzali's Ibya' 'ulum al-din, see Gramlich (1984).

14 There is a vast literature on shrines. See Christian W. Troll (ed.) (1989); C. W. Ernst in Ernst, C. W. and Smith, G. M. (eds) (1993), pp. 43-67.

15 Richard Eaton (1984), p. 334.

16 For stimulating approaches by social anthropologists see Victor Turner (1979), p. 97; Dale F. Eickelman (1981), p. 228; Ernest Gellner (1985), p. 80.

17 For this important genre of Sufi music compare Adam Nayyar: Qawwali (1988); R. Burckhardt-Qureshi (1986).

18 On the crucial issue of Muslim travel and travellers see comprehensively Dale F. Eickelman and James Piscatori (eds) (1990).

19 For hadith qudsi see W. A. Graham (1977).

20 These and other important Sufic approaches and methods are introduced and discussed by Hellmut Ritter (1937); Henry Corbin (1971), transl. Nancy Pearson (1979); Shihab alDîn Maqtûl Suhrawardî: The Mystical and Visionary Treatises of Subrawardi, transl. Wheeler M. Thackston Jr (1982); Fritz Meier (1957).

21 Compare also Carl W. Ernst (1994), pp.5-10.

22 On the mystical techniques, ideas and institutions such as mystical orders, see J. S. Trimingham (1971); A. Popovic and G. Veinstein (eds) (1985); Henry Corbin (1976); Fritz Meier (1992).

23 On this famous Sufi and scholar see for example Michel Chodkiewicz (1986), English transl. Seal of the Saints, by L. Sherrard (1993); W. C. Chittick (1989).

24 Compare S. H. Nasr (ed.) (1991), pp. 304-315; still interesting and useful is Franz Taeschner (1979). 
25 For the impact of Sufis in Empire-building compare Michel M. Mazzaoui (1972); Said Amir Arjomand (1981); Halil Inalcik (1973); Paul Wittek (1938), reprint, London 1982; Carl Ernst and Bruce Lawrence (2002); Annemarie Schimmel (1980), esp. Chapters 3-5.

26 This has been elaborated in detail by Carl Ernst (1999). I am grateful to Carl Ernst for sharing his insight.

27 It must be noted that Sirhindi, like Shah Wali Allah, has been rather ideologized from a contemporary point of view. On Sirhindi see Johan G. J. ter Haar (1992); also Arthur Frank Buehler (1998). Still relevant is the study by Yohanan Friedmann (1971).

28 Actually, this idea had already been formulated by the Iranian Kubrawi sufi 'Ala al-Din Simnani (d. 1336) two centuries ago. See H. Landolt (1973) and Pierre Lory (1990), pp. $177-187$.

29 Compare for example Muzaffar Alam and Sanjay Subrahmanyam (eds) (1998), who elaborate on these developments in some detail in the context of South Asia.

30 On the social history of the early Wahhabiyya see Esther Peskes (1993).

31 The whole issue of mystic reform in the eighteenth century is still very much debated. Compare Fazlur Rahman (1979), who first used the term 'Neo-Sufism;' Reinhard Schulze (1990); a critical survey is provided by R. S. O'Fahey and B. Radtke (1993); R. S. O'Fahey (1990); N. Levtzion and John O. Voll (eds) (1987); Annemarie Schimmel (1985b); John Voll (1982); Jamal Malik (2003); Peter Gran (1979); Rudolph Peters (1980), pp. 131-145.

32 As has been discussed by Bruce Lawrence and Carl Ernst for instance in connection the famous Chishti Ashraf Jahangir Simnani (d. 1427), the spiritual leader of the political master Ibrahim Sharqi in Jaunpur.

33 For the subsequent developments in the nineteenth century in the context of colonial intrusion see for example P. B. Clarke (1995); Jamil Abun-Nasr (1965); Knut S. Vikor (1995); Mervyn Hiskett (1976), pp. 125-169; John Hunwick (1994), pp. 308-328; Ali Salih Karrar (1992); Christine Dobbin (1983); Karel Steenbrink (1993).

34 A comprehensive overview on these developments is provided by E. Sirriyeh (1999).

35 Fazlur Rahman (1979), p. 153.

36 Compare E. Sirriyeh (1999), Chapter 6.

37 For a contextualization of various issues in reference to religious pluralism see my 'Introduction', in Jamal Malik and Helmut Reifeld (eds) (2004), pp. 1-20.

38 For the growing trend, particularly among young American Muslims to use Islam as a means to assert an independent identity, see Marcia Hermansen in Safi, O. (ed.) (2003), pp. 303-319.

39 Compare Nilufer Göle (1995).

40 D. F. Eickelman and James Piscatori (eds) (1996), p. 5.

41 See Mark Sedgwick in B. O. Utvik and K. Vikor (eds) (2000), pp. 251-269.

42 For this optimistic viewpoint see also Marcia Hermansen in Clarke, Peter (ed.) (1997), pp. $155-178$.

43 This has been used in different contexts, such as P. R. Ireland (1994).

44 For structural differences between British, French, German and the USA societies see the illuminating study by Werner Schiffauer (1997).

45 Ludwig Hagemann and Reiner Albert (eds) (1998), pp. 128-131.

46 See for example the studies by Olivier Roy (1995) and Gilles Kepel (2000), who have extensively written on the decline of contemporary political Islam. 


\title{
1 Literary productions of Western Sufi movements
}

\author{
Marcia Hermansen
}

The following contribution will focus on the literary productions of Western Sufi movements, with attention to determining the major genres represented and why these are selected. As a scholar of religion, I am concerned that studies of Western Sufi movements might easily become confined to the realm of social theory and immigrant religion. I therefore wish to open up the writings emerging from these movements to critical appreciation and analyses from other perspectives.

I will discuss aspects of the new, Western Sufi literery works that challenge their being perceived as marginal discourses. Since many of these writers are of European or Euro-American background, in terms of social location they could be construed as privileged. Some of the works assume this privilege, others may reflect a sense of a certain marginality with respect to mainstream Western culture as well as a centralized, authoritative Islamic discourse. Thus there is more than one type of conceptual location evident within the writings emerging from Western Sufi movements.

I will commence with a brief outline of Sufism in the West and then proceed in the body of the contribution to deal with Sufi writings.

\section{Sufism in the West}

In order to get some grasp on the scope of the movements behind these materials I invoke a model I proposed in earlier papers of a 'garden' of American Sufi movements in which there are perennials, hybrids and transplants. ${ }^{1}$

I am using the term 'hybrids' for those movements that identify more closely with an Islamic source and content. In America these hybrid Sufi groups generally are founded and led by immigrant Muslims who were born and raised in Muslim societies. ${ }^{2}$ Within those parameters, there are a wide range of responses and adaptations to the hybrid context in which they operate, for example in the membership of the movements.

The 'perennials' of the garden are those movements in which the specifically Islamic identification and content of the movement have been de-emphasized in favour of a 'perennialist', 'universalist', or 'traditionalist' outlook. ${ }^{3}$ I am using the term 'perennialist' in its broadest sense to refer to the idea that there is a universal, eternal truth that underlies all religions. ${ }^{4}$ Certain movements deliberately espouse the "perennialist' title as articulated by Rene Guenon, ${ }^{6}$ and later Frithjof Schuon and his intellectual circle. 
Most of these perennialists would say that adherence to and practice of a specific tradition is essential, so that while ultimate truth is universal, practice is specific and particular. ${ }^{7}$ Perennialists in the Schuonian tradition are characterized by an antimodern and somewhat millenarian vision. Other perennialist or universalist movements simply have an orientation that spiritual practices from various religious traditions may be combined ${ }^{8}$ since they all emerge from the same true source which is, in fact, primarily gnostic, rather than religious.

Transplants is the term I use to refer to Sufi movements conducted among small circles of immigrants with less adaptation to the American context. The transplants are the Sufi groups whose literature I will spend the least time on here, although they are certainly interesting from the perspective of transnational Sufi discourse. The fact that they appeal primarily to immigrants means that they have less need to produce their own literature in the West. Perhaps one could argue that the need to produce works in English or other Western languages is a signal of the hybridization of a Sufi movement. This is either due to its need to appeal to indigenous European or American populations, or to address a new generation born in the West of immigrant origins who are no longer literate in any 'Islamic' language.

While I will discuss some of the movements and works individually, the material is by now so vast that it would require volumes rather than a paper to adequately present the history and doctrines of each of the groups, much less all of their writings. I can therefore only highlight a few general trends.

\section{Membership and relationship to Islam}

The literature on 'new religious movements' in the West sheds some light on broad characteristics of such movements. The clientele of most of the 'new' Sufi movements, whether hybrid or perennial, tends to be white and middle or upper middle class.' Most of the members are from the generation of the late 1960s and 1970s, although there does seem to be a younger cohort now taking an interest, particularly in the hybrid movements. These hybrid Sufi movements also attract a number of immigrants from Muslim societies and their children who either were born in the United States or arrived at a young age.

The relationship to Islam is one point of entry in understanding the range of these movements. In the context of the West, and in particular, the United States, the identification with Islam raises a complex challenge to those who wish to recruit to the Sufi movements. In the case of the perennialist movements it is less of a problem, since Islam is just one of many religious traditions which they honour. Members of such movements do not have to become formal Muslims, practise Islamic ritual, or follow any specific dress code.

Examples of perennial/universal movements are 'The Sufi Order International', ${ }^{10}$ led by Pir Vilayat Khan and now his son Zia Inayat Khan, the 'Society for Sufi Studies' of Idries Shah (1924-1996) and the 'Tradition' of his brother Omar Ali Shah. ${ }^{11}$ Both Vilayat Khan and Idries Shah were born in Europe of Indian fathers and Western mothers. While Shah's works are liberally pervaded by the term 'Sufi', references to Islam, or even to 'God', for that matter, are rarely encountered. The sense is rather 
that of an occult wisdom or a psychological training system, which will be revealed only to a circle of initiates.

Among all peoples, in all countries, there is a tradition about a secret, hidden, special, superior form of knowledge accessible to man after passing through circumstances of difficulty. ${ }^{12}$

Since the death of Idries Shah, many of his disciples have become affiliated with his brother Omar Ali Shah, whose teachings and organization, while similar, also display some distinctive features. For one thing, Omar Ali Shah has many more followers in South America, ${ }^{13}$ his movement attracts younger people and there are more references to Islam in his writings. ${ }^{14}$ There is some indication that Islamicate practices are performed as part of this movement. For example, a follower of the 'Tradition' describing his process of fighting cancer, mentions his practices of reciting the Fatiba (the opening chapter of the Qur'an), dhikr and 'Ya shifa' [sicc. ${ }^{15}$

Other 'universalist' Sufi movements active in the United States are the Sufi Islamiyyat Ruhaniyat Society (Sam Lewis, d. 1971/Moinuddin Jablonski, d. 2001) and the Golden Sufi Center (Irena Tweedie, d. 1999/Llewellyn Vaughan Lee). ${ }^{16}$

The hybrid Sufi movements are relatively newer on the scene, probably due to the fact that it was not until the late 1960s that immigration became more feasible for teachers born in Muslim societies. ${ }^{17}$ Examples of hybrid Sufi movements are the Bawa Muhaiyaddeen Fellowship, ${ }^{18}$ the Helveti-Jerrahi and the NaqshbandiHaqqani (Shaykh Nazim). ${ }^{19}$ Since many readers are likely to be unfamiliar with these movements, I will briefly describe the development of several tariqas in the American context.

The Bawa Muhaiyaddeen Fellowship was founded by a Singhalese teacher, Guru Bawa Muhaiyaddeen, who first came to the United States in 1971. He gradually gathered a group of Western disciples at his Fellowship in Philadelphia, which is particularly remarkable since he was already quite elderly and never learned to speak more than rudimentary English. ${ }^{20}$ (This movement is treated in Chapter 4 of the present volume.)

The Helveti-Jerrahi Order was brought to America by Shaykh Muzaffer Ozak (1916-1993). ${ }^{21}$ Ozak first came personally to America in 1980, although many Western students of Sufism had previously visited his bookshop in Turkey. Branches of his tariqa developed in New York under the leadership of Tosun Bayrak ${ }^{22}$ and Shaykh Nur (Lex Hixon 1941-1995), ${ }^{23}$ and in the San Francisco Bay Area under Ragip Frager.

The Naqshbandi-Haqqani order is headed by the Cypriot teacher Shaykh Nazim ${ }^{24}$ and is probably the most popular of the hybrid movements in the United States. ${ }^{25}$ (This movement is treated more extensively in Chapters 5 and 6 of the present volume.) In addition, during the course of this contribution I may cite writings from Islamically oriented Sufis and movements other than these.

\section{Sufi writings}

Western Sufi writings are in some sense comparable to Adab Islami or Islamist literary works ${ }^{26}$ in suffering from similar scholarly neglect for some of the same reasons. 
The contemporary critic of Arabic literature, Fedwa Malti-Douglas, commenting on the marginality of Islamist writings in critical study, notes:

These religious texts may be popular among a certain group of readers, but they are far from popular among cultural and literary critics. The occultation of the more literary texts of the Islamic revival comes about because of the unwitting collusion of different academic specialities. On the one hand, most studies of religious movements concern themselves with political and theological questions. It is therefore no accident that most western authors of book-length studies on the Islamic revival should not be cultural or literary critics. On the other hand western specialists in Arabic and other literatures of the Middle East, or the Islamic world, or even the Francophone world, consciously confine themselves to the enormous secularized literary and cultural production of the region, perceived as it is to be artistically serious and, hence, more worthy of study. ${ }^{27}$

In an earlier article on American Sufism, Gisela Webb suggests that scholarly attention to Sufi movements in the West has been limited by perceptions of such movements as cults, New Age movements, etc. The fact that Sufism itself is an 'alternative' discourse in the Muslim world, as well as the fact that some of these Western Sufi movements deny any essential connection of Sufism with the religion of Islam also makes locating them problematic. ${ }^{28}$

In speaking of 'literary' productions I am using the term in its broadest sense. Literary contributions of Western Sufi movements are only rarely made in artistic genres such as novels and poetry; more often they are translations, self-help manuals, or spiritual autobiographies. The audience varies from literature displayed at mainstream Muslim conventions such as the Islamic Society of North America, to publications on self-development geared to the occult and New Age bookstore market, to polemics about questions of Islamic practice. The writings produced by American/Western Sufis often have a very local applicability - while some travel better than others, many would clearly only appeal to devotees of a particular movement.

Occasionally writings emerging from Sufi movements in the West touch or inform broader networks, for example the novels of Doris Lessing, ${ }^{29}$ the Rumi poetry translations of Coleman Barks, ${ }^{30}$ and in academia the influence within Religious and Islamic Studies of the writings of Huston Smith and Seyyed Hossein Nasr. ${ }^{31}$

\section{Literature as practice}

The publications of Western Sufi movements draw on both traditional Islamic and contemporary Western genres and models. A striking example of adaptation or multi-level translation is the popularization of the theory of Sufi story telling by Idries Shah, in particular his emphasis on the therapeutic function of the surprising anecdotes and fresh perspectives of these tales. The transformative role of being exposed to puzzling and surprising tales that would destabilize the student's regular (and unaware) mode of consciousness was further explored by Shah's deputy (khalifa), the 


\section{Literary productions of Western Sufi movements}

American psychologist Robert Ornstein. Reading and discussing these tales in groups became a significant component of the activities of the members of Shah study circles. Shah's interpretation portrayed the Mulla Nasruddin stories of Muslim cultures, ${ }^{32}$ which had previously been considered folkloric, as Sufi parables.

The following quote illustrates his locating the purpose of recounting these stories in the realm of psychological theory: 'Many have been misled, because this kind of literature has its own conventions, into believing that Sufi classical writings are other than technical descriptions of psychological states. ${ }^{33}$

Reading, rereading, discussing and interpreting the Sufi stories was a central component of Idries Shah's teaching method and has been compared to a 'dhikr' by some of his followers. The Idries Shah group sponsors its own press, Octagon, which republishes translations of Sufi classics. An important activity or 'work' of Shah followers has been to promote and distribute his publications, both for the purposes of fund-raising and for disseminating the teachings with the ultimate goal of transforming public awareness to the greatest extent feasible. One brochure, sent out by ISHK publications, a Shah organization, to members of the Middle East Studies Association after the 9/11 terrorist attacks, advertised books by Shah and his circle with content relevant to Afghanistan, thereby connecting these publications to the need for heightened cross-cultural understanding. This is particularly interesting in the light of my argument, since it illustrates the connections made between publishing activities, academics and Western Sufi movements.

\section{Networks of dissemination of Sufi literature}

The dissemination of Western Sufi literature is transnational and is one major way in which the European and American branches of a single order share outlooks and teachings irrespective of local cultural trends. Of course, the international language of Sufi movements is English, increasingly becoming the international language of Islam in general. To what extent the Internet will displace print publications remains to be established. ${ }^{34}$ More and more Western Sufi groups distribute information in Sufi cyberspace ${ }^{35}$ including Sufi orders' web pages and discussion lists. Garbi Schmidt, in a study of the Haqqani web page, nicely points out issues raised by the use of this medium such as the commodification exemplified by the linked 'Sufi Shopping Network'. ${ }^{36}$ An observation I made while recently scanning some Sufi web pages is that the more elaborate and professionally designed web pages tend to have stronger commercial interests and objectives, signalling a possible intent behind certain movements. For example, the image of a map with red dots indicating tariqa branches world-wide is rather reminiscent of hotel chain advertisements.

A further question about Sufi self-publishing activities raised by considering the Internet is whether charisma and community affiliation is more or less able to be transmitted through this medium than print. Dale Eickleman and Jon Anderson, drawing on the work of Benedict Anderson refer to the 'growing sense of reading together' in which 'the public sphere emerges less from associations, more strictly the domain of civil society, than from ways of dealing confidently with others in an expanding social universe of shared communication. ${ }^{37}$ Whether the imagined Sufi 
communities of the Internet can transmit the benefits of subbat (the company of the shaykh and other seekers) and tariqa identity and loyalty remains to be seen.

As far as print forms of Sufi literature are concerned, sites of dissemination include occult bookstores, Islamic bookstores, Islamic conferences, Sufi conferences, mainstream book trade and self-publishing. For example, representatives of Idries Shah Publications, who are local members of Shah Groups, regularly operate a booth at the annual Chicago Book Exhibit, a national commercial exhibit for publishers and their clientele. In some cases lectures and articles are both published in print and posted on the Internet.

The number of distributors and publishers of Sufi books is impressive and still expanding. Among the well-known publishers specializing in Sufi books are: Omega Press (Sufi Order), Kazi Publications in Chicago (Haqqani Order), Threshold Books in Vermont (Mevlevi), Sufi Books/Pir Press (Helveti-Jerrahi) in New York, Inner Traditions, the Islamic Texts Society (Schuon/Miriamiyya), Fons Vitae (Schuon/Miriamiyya), Octagon Press (Idries Shah) and the Foundation for Traditional Studies. Some of these publishers are affiliated with specific Sufi orders, some specialize in a particular perspective, for example, perennialism. Many of these publishers also offer a wide range of other Sufi-related books. The ones affiliated with universalist orders such as Omega Press may offer books on other spiritual traditions, while the Islamically oriented Sufi publishers may carry general titles on Islam (Kazi Press, for example).

There is also a counter practice of 'secret' Western Sufi literature that is only shared with initiates. For example, the Sufi Order previously circulated a series of unpublished texts of Hazrat Inayat Khan known as Gathas, Githas, Sangathas and Sangithas exclusively among higher initiates. ${ }^{38}$ These were to be read as part of closed sessions and were kept only by leaders of local centres. At least some of these writings, the Gathas, were 'declassified' and published by the European branch of the Order in 1982. Within the two branches of the Shah movement, certain texts are privately circulated and are not supposed to be shared with outsiders. Part of a scandal involving the Miriamiyya tariqa involved the fact that a defector distributed photographs, doctrines and practices promulgated by Frithjof Schuon beyond the limited audience of his disciples. These materials were considered offensive or heretical in broader contexts. $^{39}$

\section{Genres of Sufi literature}

The types of writings produced by these Sufi groups include: transcribed lectures, polemic and instruction manuals, hagiography, biography, autobiography, literature (poetry and novels), Sufi psychology, translations, academic studies and Sufi op-ed (opinion) pieces.

\section{Transcribed lectures}

A literary form used by both universalist and hybrid Sufi movements is that of the lecture transcribed from tapes or disciples' notes. In one of the earliest instances, the writings of Hazrat Inayat Khan, almost all of the voluminous material was assembled 


\section{Literary productions of Western Sufi movements}

posthumously and edited by disciples. This has led to some discussion as to the accuracy of the transcriptions. The words of the master are now available on CD so that they are available for key-word searches and other sorts of logical operations by computer, in addition to being read. This gives some evidence of their canonical status, and their use in the teaching of further disciples. The transcribed lecture format in Inayat Khan's case was perhaps due to the fact that his untimely death did not leave him time to record his teachings in a formal literary way. It may also have been favoured due to the intuitive form of his teaching, or due to second language issues arising from his mode of communicating in spoken, rather than written English.

More recent Sufi teachers whose lectures are transcribed, for example, Shaykh Nazim, also face the issue of spoken English versus the written language. Over time, the quality of production and transcription of his lectures has improved notably. Omar Ali Shah's lectures have been similarly recorded for distribution in printed form. That the teacher is too occupied to sit down and write is also possible. The transcribed lecture format is notable in some other religious leaders of the Muslim modern age, for example, Ali Shariati (d. 1978) in the sense of his being a charismatic leader who was on the move too much to record his thoughts in formal compositions.

The reproduction of Sufi teachings on cassette and videotape is a further, yet distinct example of a mode intermediate between direct contact with the teacher and the printed word. Disciples of teachers such as Guru Bawa, who made extensive recordings of his lectures, could be seen as having prepared an archive for future pupils. In literary terms, the format of transcribed teachings is not uniquely modern in the Islamic Sufi tradition. Notable are the malfuzat, or recordings of teaching sessions made in the Indian Chishti Order. ${ }^{40}$ One notes, however, that the malfuzat tended to be terse and anecdotal rather than the lengthy lectures recorded by contemporary Sufi masters.

\section{Polemic}

Exemplifying another type of Sufi literature, Shaykh Hisham of the Haqqani Order uses the modes of controversial literature or polemic more than most other Sufis in the West. ${ }^{41}$ This may reflect his more explicit decision to engage in debate with Muslim 'Wahhabis' who are directly criticizing Sufi practice and metaphysics. ${ }^{42}$ This polemical genre is reminiscent of modern South Asian fatwa wars between members of the Barelwi, Deobandi and Ahl al-Hadith schools of thought ${ }^{43}$ and I assume some similar writings in Turkish and Arabic. Besides the writings promulgated by the Haqqani group, the writings of Shaykh 'Abd al-Qadir as-Sufi ${ }^{44}$ and some writings of his followers are noteworthy for their strong polemic and apocalyptic tenor. ${ }^{45} \mathrm{An}$ example of a statement from the group's website after 9/11 follows:

All the struggle of the Ladenites has been waged by spending US dollars. It has taken place completely within a kafir dialectic and the banner of Islam has never been raised high. Beyond this tragic incursion of the US forces again into Muslim lands there has to come a growing recognition by the Muslims, both their civic leadership and their Fuquha, that the path to success for the Muslims 
is in the restoration of the fallen pillar of Zakat. It is a pillar which demands payment in gold dinars and silver dirhams along with the other known categories. It cannot be paid in paper money. In turn, it demands the appointment of local Amirs who order its collection for Allah, glory be to Him, has ordered in His Book, 'Take!' Thus the restoration of Zakat will mean the restoration of 'Amr and that in turn will lead to the restoration of Khalifate, most certainly. And, as it happens and Muslims withdraw from the usage of the forbidden paper currency the dragon of kufr, bled of its lifeblood, false money, will die. The waves on the surface will remain troubled and many ships will be dashed to pieces on their storm, but below the strong currents move in our favour as we return to an obedience which is dependent on our recognising the true weapon of our enemies - the US dollar, whose text openly declare its intention of kafir world dominance. The plot of Allah is greater. ${ }^{46}$

Soon after, this website was no longer accessible without a password. The themes of restoring the Caliphate, reinstituting gold currency, rejecting modern banking and so on are typical of the projects of this movement.

\section{Hagiography}

Since Sufism places so much emphasis on the blessings of the saints of the past, even the universalist orders retain some of this hagiographic tradition, for example, the Sufi Order work of the 1970s, Toward the One, lists the lineage of the Chishtis. ${ }^{47}$

Hagiographic genres in classical Islamic writings are usually known as the tabaqat (books of ranks) or tazkirat (memorials) of the Sufis. The work Naqshbandi Sufi Way of Shaykh Hisham Kabbani is notable in its memorialization of the saints of the Naqshbandi Order, culminating in the hagiography of Shaykh Nazim, complete with pictures and miracle stories. ${ }^{48}$ In this it is similar to contemporary works being produced by Sufi orders in India and Pakistan. Support for the project was ensured by murids having to commit $\$ 99$ in order to acquire a personal copy.

\section{Poetry}

Relatively little original poetry has been produced by members of Western Sufi movements. Examples are works by 'Abd al-Hayy Moore ${ }^{49}$ and Avideh Shashaani. ${ }^{50}$ Hazrat Inayat Khan composed his own poetry in Urdu and his commentary on the spiritual role of Persian Sufi poetry, The Hand of Poetry, ${ }^{51}$ has been reissued with reworked translations by the popular American interpreter of Rumi, Coleman Barks.

\section{Sufi op-ed pieces}

An emerging genre among the more intellectual members of Western Sufi movements is the commentaries of public intellectual convert Sufis (Pics). Subsequent to the attacks of September 11, 2001, Western Muslims have felt compelled to raise their voices more publicly against tendencies that are usually both anti-West and anti-Sufi. 


\section{Literary productions of Western Sufi movements}

An analysis of this type of material goes beyond the scope of this essay, but it might be worth reflecting on the coalescence of certain themes, 'Abd al-Hakim Murad.

The idea of being well versed in Western knowledge, society and theory, while espousing Sufi 'traditionalism', whether explicitly associated with Sufism or not, is characteristic of such writings. In fact, in order to reach multiple audiences - nonMuslims, Westerners, Muslims. Sufi Muslims - the Sufi element is usually downplayed in favour of a less specific 'traditionalism', but Islamic, not universal.

- Themes include rejection of terrorism and Wahhabism, living as Muslims in the West, upholding tradition (Sunna, madhbabs).

- Authors include Hamza Yusuf, Nuh Ha Mim Keller and 'Abd al-Qadir as-Sufi.

\section{Allegory and quest novels}

The idea of allegory is common to all literature, but especially religious and morally edifying genres. The allegory of travel to spiritual pilgrimage is epitomized by Attar's (1492) Conference of the Birds, an Islamic classic in this mode. The closest forms of western Sufi compositions to such traditional allegories are quest novels such as Reshad Feild's The Last Barrier ${ }^{52}$ and 'Abd al-Qadir as-Sufi's (Ian Dallas) Book of Strangers. ${ }^{53}$

\section{Biography and autobiography}

A trend that emerged in the 1990s was book-length 'Sufi conversion narratives', accounts such as The Writing on the Water: Chronicles of a Seeker on the Islamic Sufi Path, ${ }^{54}$ Embracing Islam ${ }^{55}$ and The Face Before I Was Born..$^{56}$

\section{Themes of Western Sufi writings}

In this section I will discuss three prominent themes of Sufi writings; transformation, travel and Sufi psychology.

\section{Transformation}

In Embracing Islam, Noorudeen Durkee, ${ }^{57}$ an American Muslim Sufi, begins with his early years in New York State. He recounts childhood spiritual experiences and offers a positive view of his upbringing and family. As a young man he met artists and experienced the milieu of the hippie culture and the coming of Eastern spiritual teachers to San Francisco in the 1960s. He and his associates founded a centre, the Lama Foundation, in New Mexico where spiritual leaders such as Sam Lewis and Richard Alpert (Baba Ram Das) come to teach.

In the early 1970s Durkee worked with Pir Vilayat Khan, head of the Sufi Order in the West. ${ }^{58} \mathrm{He}$ then travelled to Jerusalem where he had many experiences with teachers in various traditions, but especially with Muslim Palestinian Sufis. ${ }^{59}$ The 
manuscript concludes by describing his return to the USA, continuing up to the point where he leaves for Saudi Arabia in $1975 .^{60}$ In fact, Durkee was instrumental in the establishment of the Dar al-Islam, a Muslim community in Abiquiu, New Mexico. He is now the American representative of the Shadhuliyya-Batawiyya, an Islamic Sufi order, and serves as a Muslim prison chaplain and imam for a number of mosques.

Durkee's voice incorporates the perspective of an American gradually embracing Islam, for example, the difficulty of beginning to integrate the prayers, do them properly, find a Muslim community in New Mexico and fast during all of Ramadan. ${ }^{61}$

Within Sufi autobiography the theme of longing for and finding the spiritual master is often a major element.

In Durkee's narrative, his road toward Islam is portrayed as emerging from natural and religious experiences which touched his soul as a child. At various points in his life, he has the sense of receiving inner guidance. ${ }^{62}$ As he moves closer to Islam he describes a gradual process of transformation.

There was still a 'me' and a 'them', but that dividing line was becoming increasingly hard to exactly define, much less retreat behind to find any comfort in. I still couldn't quite bring myself to formally declare that I was a Muslim (or 'turn myself in' as a friend of mine in later years called it), but I felt myself slipping into the rhythms and the tides that regulate the world of Islam and the Muslims and I could feel a deep change in my outlook and perceptions. ${ }^{63}$

In considering conversion to Islam and Western Sufi movements, we have to complicate the idea of conversion. One form of conversion is becoming a formal, practising Muslim. There are many stages of transformation, and joining a universalist Sufi order is also a type of conversion. The very act of conversion is disturbing to some writers; for example, Lex Hixon describes his discomfiture when being told one morning in Turkey that he had converted to Islam the night before (unbeknowst to him). ${ }^{64}$

In such conversion, narrative language and concepts of third-wave psychology and comparative religion, which are usually familiar to the authors and their readership, permit self-disclosure and analysis. American Sufi writers provide psychological descriptions of inner life made possible in turn by a richer contemporary vocabulary and shared set of concepts for describing these processes. ${ }^{65}$

One account of 'conversion' from universal to Islamic Sufism is the following description written by Lois Banner, based on interviews with Nuradeen's wife, Fran:

Fran read many Sufi authors that summer, and she talked with students at the camp who had studied Islam in Turkey, Afghanistan and India. Those students had found that the Sufis in those countries were all Muslim. Fran began to realize that only several Western orders, such as the Sufi Order in the West, allow nonMuslim to be members. She began to feel that the Sufi practices they were doing dhikr, meditation on the names of Allah, Murshid Sam's dances - were only a prelude to a deeper understanding that was inside Islam. She felt as though a breeze was blowing over her from the Islamic world like the one from India some 
ten years before, which had drawn Richard Alpert to India and influenced the founding of Lama. ${ }^{66}$

Another example of a work evoking spiritual scenes is Lois Banner's Finding Fran, a fascinating comparison of the lives of two female friends who grew up together in 1950s Los Angeles, one becoming a feminist academic historian and the other a universal seeker and finally a Sufi Muslim. The biographical material allows us to sense the currents operating in the life of Noura Durkee (Fran), who played a prominent role in such American spiritual movements as the Lama Foundation and developing an Islamic community known as Dar al-Islam at Abiquiu, New Mexico. ${ }^{67}$

Travel was a major element of spiritual experience for both Durkees, from the Pir Vilayat Sufi camps held at Camonix, France during the 1970s, then on to Jerusalem, then Mecca, Cairo and finally back to the United States. In Banner's tracing of some of the spiritual currents running through Fran/Noura's experience one finds Gurdjieff groups, Pir Vilayat, the Lama Foundation, Ram Das and Shadhili Sufism. Then, as an interesting twist, the feminist scholar Banner confesses in the introduction her own involvement in universal Sufism through participating in the dances of universal peace and her eventual initiation in the Sufi Order by Pir Vilayat Khan. ${ }^{68}$ The tone of the book is set by Banner trying to appreciate Fran's path, and the role of women in Islam in the context of a contemporary Western woman's search for spirituality. The conclusion is that smart, competent, modern people from the West might find something valuable in embracing Islamic Sufism.

\section{'Sufi travel: spiritual scenes' and transnationalism}

One way of beginning to assess both transnational and local manifestations of Sufi orders in the West is through what I term the 'spiritual scene' of a particular place and time. These scenes can to some extent be recovered from the autobiographical writings of Sufis. For example, Llewellyn Vaughan-Lee's spiritual autobiography, The Face Before I Was Born allows us to imagine some aspects of the spiritual scene in Britain in the late 1960s and 70s. ${ }^{69}$

In the case of Vaughan-Lee's book, the Zen-inspired title alerts us to the eclectic spiritual formation of the author who finds an early spiritual awakening through reading Paul Reps' Zen Flesh, Zen Bones ${ }^{70}$ as a student. Among the bases Vaughan Lee touches are Kenneth Critchlow's work on (Islamic geometry) patterns, weekend seminars, encounter groups, Zen Buddhism, Krishnamurti and Kundalini theory, ${ }^{71}$ and most of all, Jungian psychology. All of these were quite prominent in the reading lists of the 1970s. When Western Sufi writers mention the 'reading lists' of books that were most meaningful in their quest, it alerts us to the fact that in the period before 1980, personal encounters in the West with Muslim Sufi teachers were rare.

In terms of location, one function of concentrations of Western Sufis in communes or khanqabs such as the Abode of the Message (Sufi Order, New Lebanon, New York), the Bawa Muhaiyadeen Fellowship (Philadelphia), Sami Mahal (Sufi Islamiyat Ruhaniyat Society, San Rafael, CA) or the Lama Foundations (New Mexico) was to provide a context for the spiritual development of individuals through interaction 
with other seekers, as well as a forum for visiting spiritual teachers. In terms of the teachers who came, it provided an opportunity for exposure to the American context (in the case of foreigners) and the opportunity to expand networks and recruit new followers.

Travelling has been a perennial feature of the spiritual quest and a common motif of classical Sufi theory. Post-modern critics such as Deleuze and Zygmunt Bauman suggest a movement from 'pilgrimage' to 'nomadism' to 'tourism' as emblematic of these times. Omar Ali-Shah specifically addresses the purpose of his followers undertaking organized trips to exotic location sponsored by his followers in a chapter entitled 'Some Functions of the Trips': ${ }^{72}$ 'One of the functions performed in the Tradition is making, keeping and deepening contacts with people, places and things, such as making trips similar to the ones we have made to Turkey and elsewhere. ${ }^{73}$

The coming together of people and groups in a caravan or something equivalent has several functions. The places one has visited in the past and which one will conceivably visit in the future are places of the Tradition which were built upon or rebuilt and constructed from scratch, according to certain designs and specific indications as to the value and quality and position of that place in relation to other places.

There is nothing supernatural about this. On the contrary, it is a highly scientific type of construction. Such places are constructed with a definite intent, along either the magnetic or other fluxes which occur when certain types of material are put together to cause this energy to flow and increase the value of the ambience of the place.

In addition, Omar Ali Shah states: 'Any place of a positive nature which has been positively charged by a solid, revealed religion or from a good and workable philosophy will relieve a person of a lot of the negativity circulating in their being. ${ }^{74} \mathrm{He}$ depicts Sufi travel as pilgrimage to particular sites that both energize and purify the visitor.

There are now enough Western Sufi movements for one to speak of a 'Sufi scene' in the United States. For example, some of the early conferences of the International Association of Sufism on the West Coast featured teachers and lecturers from the entire gamut of Sufi orientations and organizations. The narrative and book endorsements from the book featuring American Sufi women, Women Called to the Path of Rumi indicate connections existing among the American Mevlevis, the International Association of Sufism (Nahid Angha), the Golden Sufi Center, the Dances of Universal Peace Movement, the poet Coleman Barks and the Inayat Khan Movement. In fact, many of these affinities date back to the 1960s and early 1970s when many of Samuel Lewis disciples accepted to follow Pir Vilayat Khan after the former's death, and many of the Sufi Order initiates began to make contacts with Turkish Mevlevis and Helvetis.

Western Sufis from hybrid and universal movements do not have the same diasporic imagination as those of immigrant tariqas. Their sacred geography, however, is likewise shaped by post-modern realities. As I argued in a previous paper, the trope of pilgrimage in search of the authentic is strong..$^{75}$ More recently this pilgrimage is framed as Sufi tourism - notable examples being the Shambhala tour of Turkey (2001) led by Carl Ernst and Kabir Helminski (note the confluence of publishing, travel and Sufism), and the Naqshbandi-Haqqani peace tour of Central Asia (2001). 
I am intrigued by the idea of transnationalism and how it would operate for the Euro-Americans involved in Sufism. In the case of Sufi orders operating in the West, what makes a particular group transnational? Was the Qadiri Order in the nineteenth century transnational? In other words, does the spatial schema and implicit construction of power dynamics only hold in the era of late capitalism paralleling the circulation of economic and cultural capital? Does the 'centre' of such a transnational order need to be in the West, or can an order be multi-centred, acentric, or decentric? For example, in the case of the Naqshbandi-Haqqanis, is the centre Cyprus or London - does one need the other?

Transnationalism, however, ultimately works toward transcending national identity. Thinking of Western Sufi teachers, I would construct Pir Vilayat Khan's identity as multi-national, in the sense that he physically embodies the meeting of East and West. When he travels around Europe he can linguistically code-switch from French to Dutch to German to English very fluently, more fluently, in fact, than he can speak any Islamic language. In his person, however, he visibly reflects the Indo-Persianate heritage of his father's lineage and authority. Spirituality in the Sufi Order, significantly now the 'International Sufi Order', no longer the 'Sufi Order in the West', is transpersonal, transnational and transreligious.

Shaykh Nazim and Shaykh Hisham of the Nashbandi-Haqqani Order, on the other hand, embody Islamic multi-nationalism through their knowledge of Arabic sources, their respective Cypriot and Lebanese backgrounds, and the diversity of their followers from a range of Muslim societies. Their Western component is addressed in English, although their web page is offered in a variety of languages including Russian, Bulgarian, Arabic, Greek, French, German, Italian, Polish, Portuguese and Malay. The style of the Order may code-switch from one locale to another, for example between London, where there is a strong Turkish Cypriot presence, to California, where more Americans and South Asians are involved. Marci Laughlin, who conducted participant-observer studies of the Order in both Cairo and Cyprus, notes the process of individual 'negotiation' that goes on as each disciple (murid) interprets the shaykh according to their own background and understandings. One male murid stated that "Shaykh Nazim was appealing because "he is a genuine tenth century man: simple and traditional"; for another follower, the shaykh was the perfect twentieth century man: "modern and open". In essence "he is man for all seasons". ${ }^{76}$ An additional observation was the variation in style and message of the Naqshbandi shaykhs in different cultural contexts and to varying audiences. One Egyptian murid felt the shaykbs had de-emphasized the Qur'an. 'She hypothesized that the themes of Shaykh Adnan and Shaykh Nazim were oriented to a Western audience, to a nonnative Muslim audience: an audience that would appreciate an "Islam made Easy" approach. ${ }^{.77}$

The Haqqanis, however transnational, seem to be drawing Western members towards some visibly fused or hybrid identity in a way not evident in the universalist Sufi movements, for example by highly encouraging forms of Islamic dress that, at least in the case of Western males, are Islamicized (robes and turbans). At one point males tied scarves around these turbans that were colour coded as to ethnicity, playing on the symbolism of unity and diversity and traditionalism simultaneously. 
Eventual discomfort with the idea of ethnic emblems may be taken as symbolizing a shift in perception as to the nature of transnational versus multi-national identity.

\section{Sufi psychologies}

A major theme of the literature inspired by Western Sufi movements is psychological models of transformation and healing. The parallelism between the Sufi shaykh and the Western psychotherapist has long been recognized, as has the usurpation of the prerogatives of traditional healers and teachers by the psychologist and psychiatrist in modern Western secular culture. ${ }^{78}$

Western Sufi often choose to contribute to this aspect personally, by being or becoming therapists; institutionally, by sponsoring conferences and forming organizations for 'Sufi Psychology' and in written form, whether formally credentialed or not. The clientele of American Sufi movements who are spiritual seekers naturally also take a strong interest in contemporary psychological approaches to personal growth, especially those of humanistic and transpersonal psychology. Idries Shah and Vilayat Khan are two perennialist Sufis who are conversant with psychotherapeutic discourse and who contribute to it at some level. ${ }^{79}$ In addition, attempts to bridge Islamic and contemporary psychological models have been made by the Western-trained psychologists Reza A. Arasteh, ${ }^{80}$ Muhammad Shafii ${ }^{81}$ and Laleh Bakhtiar. $^{82}$

Both temporally and spatially, transpersonal or third-wave psychology and Western Sufi movements have similar trajectories, dispersals and pilgrimage routes. ${ }^{83}$ The 1960s and 1970s marked the rise of both phenomena; the San Francisco Bay area was especially prominent. The third-wave psychology movement accepted a plethora of approaches to human transformation. This could be illustrated, for example, by the book Maps of Consciousness, by Charles Tart, or by the contributions of Ken Wilber to formulating general models which see Eastern meditative techniques and the esoteric teachings within the monotheisms as accomplishing the same things. ${ }^{84}$

Among Western Sufi movements, we perceive some of the complexities within transpersonal approaches so that one may classify a number of competing models for the transpersonal and cultivating consciousness.

One may distinguish between psychologies that are directly 'inspired' by Sufi spirituality and psychologies and holistic therapeutic techniques that have their origins outside the Sufi tradition but that are made use of by Western Sufi practitioners because they are viewed as consistent with or complementary to Sufi interest in personal transformation and healing. Jungian psychology, the various transpersonal psychologies (Wilber, Tart, Ornstein, etc.), and the more recent 'soul' psychologies (e.g. James Hillman, Thomas Moore) all have in common the idea that human beings must find a way to be in touch with and live in harmony/union with some transcendent or transpersonal source of meaning and orientation. Where they locate and how they label this source varies (e.g. how much it is beyond and how much it is within the person). The more explicitly spiritual psychologies that see this transpersonal reality as God or the divine are probably the closest parallels to the mystical way in various traditional forms of spirituality, including Sufism. 


\section{Literary productions of Western Sufi movements}

A number of the Western Sufi movements seem to espouse a sort of 'scientism' in which their psychological understanding will ultimately be validated by scientific proofs. Scientism seems to be a quotient factor for how universal a movement is. If the basis of transformation is ultimately the same, then it should correlate with a 'unitive' scientific model. The perennialists in the tradition of Schuon, however, strongly reject the echoes of modernism in contemporary 'scientist' discourse and wish to 'retraditionalize' science as a sacred discipline. This approach is evident in the works of Seyyed Hossein Nasr.

Gauri Vishvanathan observed that:

In a recent study, Donald S. Lopez has perceptively noted that the modern West has constructed Tibetan Buddhism less as a religion than as a science. In part this is a result of the West's own requirements that esoteric knowledge conform to the expectations of regularity, predictability and control. ${ }^{85}$

The relationship of psychology as science to explaining Sufi practice and experience also appeals to the European Sufi, e.g. in Michaela Ozelsel's diary of a forty-day spiritual retreat in Turkey, described as 'the diary of a traditional solitary retreat with an accompanying scientific commentary'. ${ }^{86}$

Further examples of this connection are that both of the movements coming from the Shah Maghsoud Angha line, the International Association of Sufism and the MTO (Maktaba Tarigha Oveysiyya) have established their own Associations for Sufi Psychology. Representatives teach in psychology programmes (e.g. at the California Institute of Integral Studies) and hold academic conferences under the rubric of 'Sufi Psychology'.

A publication by a member of the International Association of Sufism, The Gift of the Robe, exemplifies an understanding of the role of science in proving spiritual truths.

Towards the end of the nineteenth century, Sufism came into contact with contemporary Western science and within some circles, Sufism began to be transformed into a practical school grounded in scientific principles. ${ }^{87}$

The reinterpretation or translation, if you will, of Sufi teachings into contemporary psychological discourses may reflect what Eickelman and Anderson term a 'reintellectualization': of Islamic discourse 'we mean presenting Islamic doctrine and discourse in accessible, vernacular terms. Even if this contributes to basic reconfigurations of doctrine and practice.' For example:

Islamic discourse has not only moved to the vernacular and become more accessible to significantly wider publics, it has also become framed in styles of reasoning and forms of argument that draw on wider, less exclusive or erudite bodies of knowledge, including those of applied science and engineering. ${ }^{88}$

While these scholars were primarily concerned with Islamist writings generated by intellectuals in the Muslim world, the extension of the paradigm to Western Sufis indicates the complexity of globalized Islamic discourse.

In concluding this section on Sufi Psychologies I note that I have only been able to suggest a rather cursory outline of the psychological frameworks and therapeutic techniques adopted by Western Sufi movements. As expected, there is again a continuum 
from the universal to the specifically Sufi Muslim approaches. I might note, however, that the perennialists would specifically reject scientism in favour of 'traditionalism'. I would also note that in some orders the master-shaykh interaction would reduce the need for therapeutic models that could be generalized and applied by 'therapists as khalifas'.

\section{The academic study of Sufism as Sufi literature}

The presence of Western Sufis in the academic study of Islam both in some European countries (Britain and France) and the United States is striking. Most represent a certain cohort of students in the 1970s impacted by Third Worldism and a desire for a resacralization.

Encounters with traditional Islam and in many cases educations supported by the new field of area studies positioned these scholars to have a impact in the translation, interpretation and analysis of Sufi works. I point this out to expand our concept of what constitutes Western Sufi literature. At times the boundary between an academic study or textbook and an exposition of Sufism as the truth may become blurred, for instance in Seyyed Hossein Nasr's studies of Islamic spiritual themes, William Chittick's studies of Ibn 'Arabi and his school and numerous other examples.

\section{Conclusions}

In summary, I would like to address the extent to which we can consider Western Sufi writings vehicles for expressing a fusion of perspectives (Islamic and Western, traditional and modern) at the same time as they code struggles of identity, authority and location.

Members of Western Sufi orders are constantly negotiating traditional symbols and methods with their experiences as contemporary individuals from or living in Western environments. Some Sufi teachers negotiate these tensions by explaining why certain methods are chosen over others and how correspondences exist among therapeutic/scientific approaches and various spiritual paths. The more universal a Western Sufi order is, the more this selectively comparative approach may be invoked. A tension between affirming essential difference of individuals and cultures and promoting a universal message therefore exists. For example, an answer given by Pir Vilayat Khan to a questioner regarding the benefits of the macrobiotic diet was to the effect that what is suitable for a cactus may not be suitable for a tomato, the implication being that Westerners may not benefit from all Eastern techniques.

How Western Sufi movements create some sort of fusion between invoking the authenticity of traditional methods and addressing the needs of contemporary Westerners is reflected in their literary works. Western Sufis who are drawn to the field of psychotherapy have tried to integrate understandings of classical Sufism with other models including scientific, New Age, comparative religionist and psychotherapeutic.

Common themes in Western Sufi writings are the need for interpretation, translation and negotiation of individual experience. Several dissertations on the NaqshbandiHaqqani illustrate this. ${ }^{89}$ Questions raised by those who examine this movement that 


\section{Literary productions of Western Sufi movements}

emphasizes the charismatic teaching authority of the Shaykh are, 'Does he have a method, and how is it efficacious?' It is also clear from participant-observer reporting that teachers within Western Sufi movements, especially those who have murids from both Western and Islamic backgrounds, modify their self-presentation and methods in varying contexts.

As might be expected, members of Western Sufi movements, whether 'Islamic' (hybrid), 'New Age' (perennials) or immigrant (transplant) favour types or genres of writings most compatible with their orientation, and there is a further tendency for certain orders to specialize in particular genres. While the more shari ${ }^{\prime} a$-inclined movements might favour translations and instruction manuals, novels and quest narratives are more likely to emerge from universal/New Age Sufi movements.

Rather than the moral self-fashioning and call for societal reform typical of the Adab Islami works of contemporary Islamists, Western Sufis tend to produce writings of spiritual transformation and esoteric symbolism. While Sufi works of this past treated these themes through allegorical writings and manuals of practice, contemporary Western Sufis prefer autobiography and psychology as frameworks for discussing personal change. When they are addressed, relationships to the surrounding society and contemporary Western culture may range from Islamic Sufism as a space to articulate anti-modernist or even apocalyptic and militant themes, to the embrace of a progressive agenda of pluralism, non-violence, feminism and the unity of mystical experience.

\section{Notes}

1 Marcia Hermansen (1997), pp. 155-178.

2 Although, to complicate the situation, we have the case of a hybrid Islamic movement such as the Darqawiyya-Habibiyya of which the founder, Ian Dallas ('Abdal-Qadir) is British, as well as certain immigrant-led perennial movements.

3 Mark J. Sedgwick treats this movement in detail (2004).

4 Theodore Gabbay in 'A Discussion of Sufism and a description of a sample of American Sufi Practitioners' (1988, $10 \mathrm{ff}$.) makes roughly the same distinction, characterizing the two groups as 'Islamic' and 'universal' Sufis. Gabbay suggests that the source of this distinction is the more 'universal' orientation of the perennialist teachers Idries Shah and Inayat Khan due to their Indian backgrounds as opposed to the Middle Eastern origin of the leadership of the more Islamically inclined orders.

5 A self-statement in this regard follows. 'The philosophia perennis has come to signify for those devoted to traditional studies an eternal truth at the heart of all traditions....' 'It has in fact been given its most profound and genuine meaning, ... in the writings of Frithjof Schuon, which, following upon the work initiated by Rene Guenon and then Ananda Coomaraswamy, may be said to be the most noble and complete expression of the philosophia perennis available in the contemporary world.' Seyyed Hossein Nasr, preface to Frithjof Schuon (1976), pp. vii-viii.

6 On Guenon see Mark Sedgwick (1987, 2004), Robin Waterfield (1987). Both Guenon and Idries Shah seem to have had links with occult movements and freemasonry.

7 Brief bio-bibliographies of Guenon, Schuon and his circle may be found in Jean Borella (1992), pp. 330-358.

8 Some perennialists, such as Seyyed Hossein Nasr, while asserting the unitive essential truth underlying all traditions, would counsel against attempting to mix or mingle their discrete manifestations and spiritual practices. See Jane I. Smith, 'Seyyed Hossein Nasr: Defender of the Sacred and Islamic Traditionalism' in Y. Haddad (ed.) (1991), pp. 87-88. 
9 Gabbay (1988), in a survey of 130 Sufi affiliates mainly living in the San Francisco Bay area in the mid-1980s, found that $80 \%$ had a least a college degree, $23 \%$ were of Catholic backgrounds, $48 \%$ Protestant, $12 \%$ Jewish backgrounds, (17\% reported other). Gabbay, 'A Discussion of Sufism', p. 199. A study of the Naqshbandi-Haqqani order by D. Freidberg found that members of this movement in America had a lower average level of education with almost half of the 57 respondents reporting only a high-school level. This finding would be consistent with my hypothesis that this order is relatively more 'world-rejecting' than movements such as the Sufi Order in the West. David Nicolson Freidberg (1994), pp. 116-118.

10 On the Sufi Order in the West see the paper by James Jervis in Peter Clarke (1998), pp. 211-260. Another study is Michael M. Koszegi (1992), pp. 211-222.

11 Omar Ali Shah's movement is now distinct and expanding. It is called 'The Institute for the Dissemination of Sufi Ideas'. Idries Shah's movement is also known as the 'Institute for Cultural Research' in England and the 'Institute for the Study of Human Knowledge' (ISHK), in the United States.

12 Anonymous in Sufi Teachings (1982), p. 161.

13 I have heard an estimate of 5000 followers. My main informant is a person involved in the movement.

14 Omar Ali-Shah is the author of Sufism for Today (1991), and Course of the Seeker (1988), revised and expanded edition (1996). See also The Rules or Secrets of the Naqshbandi Order (1992).

15 Omar Ali-Shah (1995) p. 249. Dhikr is the Sufi practice of repeating pious phrases. 'Ya shafi' (O One who heals) is a formula incorporating one of the divine names of God (The Healer) for curative purposes.

16 For more detail on specific movements see my paper 'Hybrid Identity Formations in Muslim America: The Case of American Sufi Movements' (2000).

17 The immigration reform act of 1965 facilitated this.

18 Studied by Gisela Webb (1994), pp. 75-108.

19 David Nicolson Freidberg studied this order from the perspective of teachings and membership in 'The Naqshbandis in America' (1994).

20 The Fellowship has smaller branches in Iowa, Boston, Connecticut, Vermont, and Sacramento.

21 Among his writings published in English are Love is the Wine: Talks of a Sufi Master in America. ed. by Ragip Frager (Pitney, VT: Threshold Books, 1987), Irshad: Wisdom of a Sufi Master. trans. by Muhtar Holland (New York: Amity, 1988), and The Unveiling of Love. trans. by Muhtar Holland (New York: Inner Traditions, 1981). A brief biographical note, together with a description of a visit by Shaykh Muzaffer to the New York community may be found in Lisette Rocher and Fatima Cherqaoui (1986), pp. 164-175.

22 Tosun Bayrak (1985). He has authored commentaries on several classic Sufi works as well.

23 Hixon's Sufi writings include Heart of the Koran (1988) and Atom from the Sun of Knowledge (1993). His branch of the order is said to have 500 members. Qalbi: Circle of Nur al-Jerrabi Newsletter No. 2, Winter 1993/4, p. 24. See also the notice in Andrew Rawlinson (1997), pp. 328-331.

24 Academic articles on this movement are, Semra Galip, 'Un Gourou Nakshbendi: Sheyh Nazim Kibrisi', pp. 437-440 and Daphne Habibis, 'Mahdism in a Branch of a Contemporary Naqshbandi Order in Lebanon', pp. 603-619 in Gaborieau u et al. (1991). The topic of Millenialism should not be overlooked by those interested in a fuller understanding of Shaykh Nazim's teachings. Ronald Geaves studies this in 'The Haqqani Naqshbandis: A Study of Apocalyptic Millenialism within Islam' (2001), pp. 215-234. See also Chapter 5 in the current volume.

25 Twelve locations in the United States where Naqshbandi dhikrs were held weekly in 1994 were mentioned in the newsletter 'Naqshbandi News of North America'. By 1999 the group claimed as many as 30,000 followers and 23 centres in the United States. According to a journalist, however, phone checks revealed a significant discrepancy in these claims (Teresa Watanabe 1999). Since the September 11th terrorist attacks Shaykh Hisham seems to have shifted his focus to political lobbying. 
26 On Adab Islami see Fedwa Malti-Douglas (1995), p. 102.

27 Fedwa Malti-Douglas (2001), p. 5.

28 Webb (1995), p. 249.

29 Doris Lessing is a prominent member of Idries Shah's movement. Book-length studies of her Sufi connection include Shadia S. Fahim (1995) and Muge Galin (1997). See also her autobiography, Doris Lessing (1997).

30 Franklin Lewis (2000, pp. 589-594), evaluates Barks' contribution as follows. 'This view of Rumi as sage leads Barks and Bly to teleport the poems of Rumi out of their cultural and Islamic context into the inspirational discourse of non-parochial spirituality, all of which makes for a Rumi who shares the social assumptions of a modern American audience. For example, in his rendition of the chickpea story from the Masnavi, Barks introduces a sexual twist, and in another poem speaks of 'sexual love', where the concept is wholly alien to the original .... Nevertheless, at his best, Barks provides accessible contemporary versions, filtered through the lens of a New Age and particularly American idiom, of a wide selection from the poetic corpus Rumi left behind' (p. 592). Barks has been associated with the Bawa Muhaiyadeen Fellowship. http://www.bookpage.com/ 0302bp/coleman barks. html is a Book Page interview that discusses this.

31 Huston Smith has been associated with Pir Vilayat Khan, Schuon and the perennialist movement. Seyyid Hossein Nasr is the successor to Frithjof Schuon in North America.

32 Idries Shah, The Pleasantries of the Incredible Mulla Nasruddin (1983a), The Exploits of the Incomparable Mulla Nasruddin (1983b), The Subtleties of the Inimitable Mulla Nasruddin (1983c).

33 Shah, in 'Tales of the Dervishes', quoted by Lessing.

34 Gary Bunt (2000).

35 Jon W. Anderson,'The Internet and Islam's New Interpreters', in Dale Eickelman and Jon W. Anderson, eds. (1999), pp. 41-56.

36 Garbi Schmidt (2004).

37 Dale Eickelman and Jon W. Anderson (eds) (1999), p. 16.

38 Members are allowed to read these materials depending on the level of their initiation. Thus, at a large Sufi Order centre there may be several levels of study groups. The European branch of the known as the Sufi Movement published The Gathas (1982) for the first time.

39 Peter Lamborn Wilson (1993).

40 A study of these malfuzat is Bruce Lawrence (1978).

41 Tayfun Atay (1999).

42 Shaykh Hisham Kabbani (1998). Large portions of this and other texts are available at http://www.naqshbandi.net/haqqani/toc.htm.

43 See for example Usha Sanyal (1996b), pp. 204-213.

44 On 'Abd al-Qadir as-Sufi and the Murabitun see Ronald Geaves (2000). I study their writings in some detail in 'The "Other" Shadhiliyya in the West', forthcoming in The Shadhiliyya, ed. Eric Geoffroy. Paris: Maisonneuve et LaRose.

45 The Darqawiyya-Habibiyya movement is led by 'Abd al-Qadir al-Murabit, formerly 'Abd al-Qadir as-Sufi, formerly Ian Dallas. Dallas, a scriptwriter who played the part of the magician in Fellini's movie 81/2 was initiated by a Moroccan Sufi, Shaykh Muhammad ibn al-Habib al-Darqawi in 1967. By 1976 he had enough followers to establish a Sufi community in Norwich, England. After a period of promoting Maliki figh as the ideal legal system, he seems to have shifted focus toward a more strict and militant Islamic position. These developments may be traced in his writings which move from The Book of Strangers by Ian Dallas, a mystical quest novel (New York: Pantheon, 1972), to The Way of Muhammad (Berkeley: Diwan, 1975) to Jihad: A Groundplan (Norwich, UK: Diwan Press, 1978) and then to Shaykh 'Abd al-Qadir al-Murabit, The Sign of the Sword (Norwich: Diwan Press, 1984). He established a community in Spain, 'the Murabitun', who minted their own gold coins to try to avoid the contamination of the interest-based international banking system and raised finds to build a mosque in Granada. One of 'Abd al-Qadir's 
recent publications, The Technique of the Coup de Banque (2000) suggests alternative economic forms as the core of struggle against the non-Muslim order. His followers continue to develop certain of these themes in their own publications. Translations of classic texts are specialities of Ayesha Bewley, biography and polemic of Ahmad Thomson, and Islamic finance and ecology of Rais Umar Vadillo.

46 http://www.murabitun.org/mur/article8.html. Viewed Nov. 2002. Now locked.

47 Pir Vilayat Khan (1974).

48 Shaykh Hisham Kabbani (1995), which is a comprehensive history of the order including the biography of Shaykh Nazim.

49 'Abd al-Hayy Moore (1996). 'Abd al-Hayy Moore had been involved in the movements of both 'Abd al Qadir as-Sufi and Fadlullah Haeri. See his biographical notice in Barboza (1994), pp. 71-72 and 'The Tongues of Poets' in Michael Wolfe (2002), pp. 178-181.

50 Avideh Shashaani is a follower of the Maktaba Tarighat Oveyssi.

51 Hazrat Inayat Khan (1993).

52 Reshad Feild (1976)

53 Ian Dallas (1988).

54 Muhyiuddin Shakor (1994).

55 Noorudeen Durkee (1993).

56 Llewellyn Vaughan-Lee (1998).

57 Noorudeen Durkee is one of the American Muslim Sufi pioneers. He was one of the creative and active intelligences behind several counterculture classics including Be Here Now, by Baba Ram Das (San Cristobal, NM: Lama Foundation, 1971) and had been a founder of the Lama Foundation, a New Age centre. Noorudeen held a high rank in the Sufi Order and produced Pir Vilayat Khan's book Toward The One (1974). Later Noorudeen found his way to Islam and a Palestinian Sufi Shaykh, Muhammad Jamal. Noorudeen and his followers returned to found an Islamic community in Abiquiu, New Mexico in the mid-1970s. While in Saudi Arabia Noorudeen made contact with prominent Saudi patrons and brought the Dar al-Islam concept into reality. The successive leadership of the institution has oscillated between Sufi and more strict Islamic orientations. Noorudeen lived for a long period in Alexandria, Egypt and returned to the USA in 1994 as the khalifa of an Egyptian Shaykh, al-Battawi. His most recent publishing venture is The School of the Shadhdhiliyyah: I Orisons (1991). He is now working on a two-volume spiritual autobiography entitled 'Embracing Islam' and the comments here are based on a selfpublished edition of the first volume.

58 Noorudeen Durkee, 'Embracing Islam', Virginia: Greenmountain School, 1993, pp. 92-94, pp. 114-209.

59 Ibid., pp. 709-745.

60 Ibid., pp. 749-905.

61 Ibid., pp. 798-805.

62 Ibid., pp. 111-112.

63 Ibid., pp. 439.

64 Barboza (1994), p. 197

65 On this topic generally, see Dicket Anthony (1978), pp. 65-90, reprinted from American Behavioral Scientist 20(6), 1977, pp. 861-886.

66 Lois Banner (1998).

67 William Tracy (1988).

68 Lois Banner (1998).

69 Llewellyn Vaughan-Lee (1998). Vaughan-Lee is a student of Irina Tweedie, a British woman who studied with a Hindu teacher in a Naqshbandi Sufi lineage. He now heads the Golden Sufi Center in California.

70 Paul Reps (1961).

71 Gopi Krishna (1970).

72 Omar Ali Shah (1994), pp. 216-222.

73 Ibid., p. 216. 
48 Literary productions of Western Sufi movements

74 Ibid., pp. 219-220.

75 Marcia Hermansen (1999).

76 Marci Laughlin (1999), p. 126.

77 Ibid., p. 159.

78 Muhammad Shafii (1968).

79 Pir Vilayat Khan (1982).

80 Reza A. Arasteh $(1974,1980)$. At some point Aresteh seems to have become associated with the Idries Shah movement; see Elwell-Sutton, 'Sufism and Psuedo-Sufism', in Encounter (May 1975, p. 16) and Aresteh's contribution, 'Psychology of the Sufi Way to Individuation' in Sufi Studies: East and West. ed. L. F. Rushbrook Williams (New York: Dutton), 1973, pp. 89-113.

81 Muhammad Shafii 1985 and 1968.

82 Laleh Bakhtiar (1976, 1993).

83 James Clifford (1997).

84 Ken Wilber (1981).

85 Gauri Vishvanathan (2000), citing David S. Lopez, Prisoners of Shangri-La (Chicago: University of Chicago), 1998, p. 81.

86 Michaela Ozelsel (1996).

87 Safa Ali Uwaysi (Michael Brill Newman) (2000), p. 69.

88 Eickelman and Anderson (1999), p. 12.

89 Marci Laughlin (1999), David Nicolson Freidberg (1994), Andrew W. Vidich (2000). 


\section{Persian Sufism in the contemporary West}

\section{Reflections on the Ni'matu'llahi diaspora ${ }^{1}$}

\section{Leonard Lewisohn}

\section{Introduction}

'The literary output of American Sufi movements', Marcia Hermansen remarks, 'is by now so vast that it would require a volume rather than an essay to adequately discuss the history and doctrines of each of the groups in detail'. ${ }^{2}$ One of the most intellectually formidable of these movements is the Persian Sufis of the Munawwar 'Ali Shah branch of the Ni'matu'llahi order. ${ }^{3}$ For the past quarter century, ever since Dr Javad Nurbakhsh, the current master of this branch, visited the USA in 1974, this order has become a major publisher of Sufi works in English, French, German, Russian, Spanish and Italian. ${ }^{4}$

The present study approaches the evolution of this branch of the Order during the last quarter century of its diaspora to the West with a view to both its intellectual and doctrinal thought as well as the exoteric socio-political dimension of its public persona. In the case of the former, theories of the historical origin of Sufism and Sufi doctrine are discussed, while in respect to the latter, institutional structures, social attitudes, types of publications, gender relations, finance, proselytization, dissemination of doctrine and public relations of this Order are explored. Based on personal interviews recently conducted both in Iran and the West, as well as reference to the Order's own extensive Persian and English language published works, the study reveals how contact with the religiously diverse climate of Western society has created new cultural expressions of traditional Sufi doctrines.

\section{Exodus and exile among the early Ni'matu'llahiyya}

Nisbat-i in rah bih 'Iraq u Khurasan nist

Hamdam-i 'Isa shudan ay khar asan nist.'

Resembling epiphenomena of the religious struggle between formalistic clericalism and poetic mysticism in Islam, ${ }^{6}$ the flight of the mystic Sufi soul away from the oppressive body-politic of Shi'ite clerical persecution and intolerance, over the past five centuries there have been numerous occasions when political circumstances obliged groups of Persian Sufis to relocate themselves outside of Iran. The founder of the Ni'matu'llahi Order, Shah Ni'matu'llah (d. 834/1431) passed several years of his 


\section{Persian Sufism in the contemporary West}

life as an internally displaced exile, having become a victim of intra-tariqa rivalry and intrigues against him by the Naqshbandi master Amir Kulal (d. 773/1371) who pressured his spiritual protégé Tamerlane to make Shah Ni matu'llah leave Samarqand, where he had accrued a vast number of followers. He moved south to Mashhad in $771 / 1369$, spent a year in Herat, and then finally settled in the village of Mahan, south of the city of Kerman in southeastern Iran. ${ }^{7}$ In the last few years of his life, Shah Ni'matu'llah was invited to India to visit the court of the Bahmani ruler of the Deccan, Ahmad Shah Wali. Although he declined the invitation, he sent his grandson Nuru'llah to represent him there. In what has been described as 'a second migration of the Ni'matu'llahi family away from religious sectarianism', ${ }^{8}$ sometime between 1433 and 1435, Shah Ni'matu'llah's son (Nuru'llah's father) and successor Shah Khalilu'llah (d. 859/1455) followed him to India, returning only once to Iran in 1441. ${ }^{9}$ This quasi-diaspora of the leaders of the Ni'matu'llahiyya from Iran to India has been described by Terry Graham as 'a situation perhaps unique in the history of Sufism', where 'the body of an order continued to operate shorn of its head, which survived separately in a distant clime'. ${ }^{10}$ A similar pattern of exile and exodus of Ni'matu'llah leaders from the Order's native heartland, Persia, has continued to the present day in the branch of the Order discussed here.

As a consequence of his political involvements, Khalilu'llah effectively became the founder of a dynasty of Sufi courtiers, so that the mystical charisma of the Order eventually became absorbed into the ceremony of protocol of the Bahmanid royal court in the Deccan. ${ }^{11}$ Over the next two hundred years, the Safavid branch of the Order back in Iran adopted Yazd as its administrative centre, collaborating and cultivating marriage ties with the Safavid police state, the silsila changing in the process into a 'moribund dynastic family tradition'. ${ }^{12}$ Throughout these two (sixteenth and seventeenth) centuries, the Indian branch often sent emissaries to Persia, but it was not until 1184/1770, when Sayyid Ma'sum 'Ali Shah formally emigrated back to Iran, generating what has been dubbed 'the Ni'matu'llahi renaissance', ${ }^{13}$ that a repatriation of the Ni'matu'llahiyya from India back to Persia took shape. During the last two decades of the eighteenth century, the lives of two principal leaders of the Order, Ma'sum 'Ali and Nur 'Ali Shah, despite their successful return to Iran after over 250 years of absence, were spent in a state of internal exile. Subject to persecution and harassment from cleric and prince alike, they wandered from city to city in Iran. For over half a century following their return from India, the Ni'matu'llahis seldom found any rest and repose from clerical intimidation. ${ }^{14}$

The same pattern continued under later leaders as well, with the fourteen years (1238/1823-1253/1837) of Zayn al-'Abidin Shirvani's ('Mast 'Ali Shah') leadership of the Ni'matu'llahiyya being spent in forced internal exile, divagating from city to city under threat of execution and trailed by fatwas for his death. However, with the accession of dervish-loving Muhammad Shah Qajar in 1834, both their internal exile and external diaspora came to an end. The material circumstances of the Ni'matu'llahi shaykhs and Sufis were vastly improved due to the influence of the Qajar Grand Vizier Mirza Aqasi (1198-1265) - a Ni'matu'llahi leader and associate of Mast 'Ali. ${ }^{15}$ Many of them were even granted royal stipends. When, in 1251/1835, Mast 'Ali's successor Rahmat 'Ali Shah was made Vice-premier of Fars (bearing the title of 'Na'ib al-Sadr') by 
Muhammad Shah Qajar's royal decree, the integration of the Order into the political and social hierarchy of Iran became secure for the next 145 years.

Since the history of Persian Sufism during this early modern period has been treated elsewhere in some detail, ${ }^{16}$ we now turn our attention to the exodus of the Ni'matu'llahiyya following the revolution of 1979.

\section{The western migration and subsequent exile of the Ni'matu'llahiyya (1973-2001)}

Dr Nurbakhsh made his first trip to the USA in 1974 on the request of some American devotees. ${ }^{17}$ In the following year the first two Khanaqahs in North America were established in San Fransisco and New York by his senior shaykh Mr Masha'Allah Niktab', and in the same year Dr Nurbakhsh travelled to England, where the first European khanaqah was set up in the Notting Hill Gate district of London. During the next three years (1976-78), Dr Nurbakhsh sent Mr Niktab، every summer for several months to the UK and the USA on a mission to initiate seekers and found centres. As a consequence of these trips, two more Khanaqahs were established on the American eastern seaboard (in Washington D.C. and in Boston), where a small group of American seekers was initiated. ${ }^{18}$

In 1979 Dr Nurbakhsh emigrated to the United States ${ }^{19}$ where, on the East and West coasts, he immediately proceeded to set up several khanaqahs. In 1983, he moved to England where he has since resided. From 1974 to the present (2002) the process of diffusion of Ni'matu'llahi Sufism in the West has culminated in the establishment of altogether twenty-five khanaqabs in lands outside Iran, respectively located in West Africa (Abidjan, Côte d'Ivoire; Porto-Novo, Benin and Burkino Faso), Australia (Sydney) and Europe (Manchester and London, UK; Köln, Germany; Paris and Lyon, France; Madrid, Spain; Stockholm, Sweden; and Leiden, the Netherlands). In North America, there are khanaqabs in Washington, D.C.; Boston, Massachusetts; Seattle, Washington; Los Angeles, California; Chicago, Illinois; Santa Fé, New Mexico; Santa Cruz, California; San Francisco, California; San Diego, California; New York, New York; Toronto, Montreal and Vancouver, Canada.

\section{Numbers, organization and social} structure of the Ni'matu'llahiyya in the West

It is estimated that some 3600 members currently exist world-wide outside of Iran. Some 2500 members can be found in North America, 500 in Europe, 100 Australia, perhaps 50 in Russia (in the khanaqah, in Moscow) and some 500 in West Africa. Congregations that gather for twice-weekly meetings in these twenty-five khanaqabs may vary in number from five to fifty persons per session. ${ }^{20}$

Although Dr Nurbakhsh is the supreme head of the Order, whose word in spiritual matters carries absolute authority ${ }^{21}$ under him are a series of shaykhs empowered to initiate seekers. Currently there are nine shaykbs in the West: four Iranian and one American shaykh in North America; three Iranian shaykhs in Europe; and two African shaykhs in West Africa; the shaykh responsible for Russian members is a Russian 


\section{Persian Sufism in the contemporary West}

citizen resident in the USA, who travels regularly to Moscow where there is a group of devotees. All current Ni'matu'llahi shaykhs are male, both in Iran and the West. Immediately below the shaykh in the hierarchy is the 'director on the way' (pir-i dalil), responsible for giving basic religio-spiritual guidance and direction to novices and postulants. Immediately below him or her is the tea-master (duda-dar), responsible for hospitality, serving tea or refreshment at meetings, a function in which he or she is assisted by a few other servers on a formal or informal basis, depending on the number of members that attend a particular khanaqah.

In all the khanaqabs in the West, one person is in charge of the day-to-day management of its affairs, who in most cases lives in the building, being responsible for answering questions of newcomers or referring them to the 'director on the way', initiating seekers or else referring them to one of the shaykhs for guidance or initiation. Depending on the number of members of the particular khanaqah, he or she may be assisted by a number of stewards (nuzar) and serving dervishes (abl-i khidmat).

The twice-weekly meetings (on Thursday and Sunday evenings, both in Iran and the West) allow dervishes to gather for prayer and meditation in the early evening to refocus their attention on the sacred dimension of their normal workaday lives. Although ritual prayers are said by the dervishes prior to the usual meditation or Sama' session, the main concentration is on observing remembrance of God in the Sufi circle of dhikr rather than keeping straight the rows of worshippers in salat.

Meditation involves listening (sama') to prerecorded Persian Sufi music and/or audio cassettes of Dr Nurbakhsh's discourses. Where native Iranian musicians present, live music is usually played. Light refreshments, usually consisting of tea and sweets, are served after the meditation. On special occasions a meal may be served. All dervishes, unless retired, have full-time occupations and professions, which range widely across the classes. In the Western Ni'matu'llahi dervish community are found bricklayers, janitors and street vendors, as well cardiologists, university professors, lawyers and psychiatrists.

\section{Adjustments to Western culture and society}

The process undergone by Iranians in Iran who seek initiation into the Order differs substantially from that implemented in the West. Aspirants in Iran, almost invariably, come from a Shi'ite Muslim background and are usually introduced to the Order by another Ni'matu'llahi initiate. Often aspirants are given litanies to recite before being vouchsafed initiation into the dhikr of the heart, and sometimes the aspirant can wait for months or years before being given formal initiation in order for the shaykh or master to ascertain the authenticity of the individual's vocation. Initiates are then given an identity booklet, much like a passport, with their name, picture and date of initiation, as well as some required prayers and litanies to be recited. Since there existed some 60 khanaqahs of the Order spread thoughout towns and cites in Iran before the revolution, and these often doubled as guesthouses for travelling dervishes from other Orders (Khaksar, Ahl-i Haqq, Naqshbandi, Qadiri, etc.), this 
identity passbook enabled stewards of the various khanaqahs to distinguish whether a certain travelling dervish was an initiate or not.

In the West, however, the identity passbook was dropped. One reason for this is that all the prayers and litanies included therein were published in a manual of Ni'matu'llahi contemplative disciplines in 1979 by Dr Nurbakhsh. ${ }^{22}$ Another is that the spiritual topography of Western spiritual culture is so diverse that dervishes from other Orders do not as a matter of course frequent the khanaqahs. Finally, up until $1991^{23}$ at least, everyone initiated into the Order in the West was either through the hand of Mr Niktab' or Dr Nurbakhsh himself, so that it was easy to discern the initiate from the non-initiate.

In Iran, communication of the Order's presence is typically conducted by word of mouth, in contrast to Europe and the United States, where the Order's representatives have found themselves subject to social constraints and mores of an extraIslamic host culture, and where Sufis are but another mystical sect surrounded by myriads of Hindu, Buddhist, Christian, Jain, Jewish and New Age groups and gurus existing in the contemporary marketplace of eclectic spirituality. Hence, whenever either Dr Nurbakhsh or his chief shaykh, Mr Niktab', entered a given European or North American city, notices were posted in bookstores, universities, health-food shops and in local mind-body-spirit newsletters, so that the wider public could be made aware of the dates of the shaykh's visit and given a contact number. Those who sought information and were given appointments were usually advised to read Dr Nurbakhsh's manual of doctrine entitled In the Tavern of Ruin in order to familiarize themselves with the tenets and teachings of the Order before meeting him or his Shaykh. Often, Western aspirants are generally allowed to attend a few sessions in the khanaqah, after which time they are expected to make a decision as to whether they wish to become initiated into the Path.

In contrast to many other Sufi orders in the West, Western initiates of the Ni'matu'llahiyya are never given Muslim names. Insofar as the true Sufi cannot be defined, ${ }^{24}$ why should he or she be (re)named? Upon initiation, ${ }^{25}$ novices are officially converted to Islam, and are taught basic performance of the Muslim ritual prayers (salat, namaz). Not much else in the way of external observance of the shari'a is required for Ni'matu'llahi dervishes to practice, ${ }^{26}$ each dervish may or may not fast during Ramadan, depending on his or her own personal preference. This overriding tariqa emphasis is reflected by the fact that the term 'Canon Law' (shari' $a$ ) does not actually occur in Dr Nurbakhsh's published discourses. His conception of prayers and fasting exclusively stresses the significance of the inward requirements of these Islamic practices. ${ }^{27}$ Shari'a observance among the Western Ni'matu'llahi dervishes is treated as a matter best left to individual judgement, as with the other canonical prescriptions: almsgiving, fasting and praying, which are recommended in theory but are left to be pursued eclectically according to personal inclination and persuasion. An aspirant for initiation is required to be self-supporting and to have a professional occupation (unemployment is discouraged); he or she should not be suffering any mental disorder, nor be addicted to drugs or have a current history of alcohol abuse. ${ }^{28}$ 


\section{Persian Sufism in the contemporary West}

\section{Gender relations}

Gender relations among the Order's members in Iran and the West currently vary greatly. In the Islamic Republic of Iran, the sexes are currently strictly segregated within the khanaqahs, so that women initiates pray and meditate together apart from men. Even before the revolution, women who might never veil themselves in public, who wore blouses and skirts at home, on the street and in the workplace, always donned a chador as a sign of respect when entering the khanaqab's precincts.

In the West, however, neither veiling nor segregation of the sexes exists. Currently in the khanaqahs in the West, men and women freely say their prayers and meditate side by side, ${ }^{29}$ sharing the same washrooms and bathrooms. Aside from being asked to cover their heads when praying, women observe no particular dress code: short skirts, long dresses and trousers are all worn and no interference with anyone's personal and individual styles of dress has ever been made in the khanaqahs in the West. ${ }^{30}$

\section{Ethnic composition of Ni'matu'llahi members in the West}

Ethnic composition of Ni'matu'llahi members varies significantly from khanaqah to khanaqah. Some khanaqabs in the USA currently have virtually no Western members (e.g. Los Angeles), whereas others (e.g. San Francisco) are equally short of Iranian members, while others (e.g. Washington, D.C.) are evenly balanced between Americans and Iranians attending on a regular basis. Until the mid-1980s, the bulk of Ni'matu'llahi initiates in the West were non-Iranians. In the early years of Dr Nurbakhsh's residence in the USA (1979-83), since Iranians were often unable to leave Iran, the unsettled political circumstances often did not permit disciples from Iran to move abroad. From 1985 onwards, however, as an increasing number of Iranians managed to travel to the West, there was a significant demographical shift in initiates and the number of Persians attending khanaqahs in the West waxed dramatically.

The intellectual and cultural character of expatriate Iranians attracted to these khanaqahs in the West from the mid-1980s onwards differed from dervishes frequenting the Order's khanaqabs in Iran. On the whole, initiates in Iran have hailed from middle-class and/or traditional religious backgrounds. Iranians finding their way to the khanaqahs in the West, however, have been of a more cosmopolitan character, coming from a broader range of social strata. They have included ex-Marxists and ex-Mujahidin supporters, teachers and engineers, orthodox pious Muslim devotees, artists, musicians, businessmen and college students. Despite this outward diversity of professional background and social class, they tend to share in common a sense of longing for their spiritual (and physical) homeland, hoping to find in Sufism some consolation from the grief and torment of exile, aiming to recapture their own authentic national Persian spiritual tradition in Sufism's bosom, and return to a more tolerant and universalistic faith beyond that of fundamentalist Islam. Many, if not most, are not religious in any formal orthodox sense of the word (ritual prayers, fasting, pilgrimage to Mecca, and reading the Qur'an are often identified with Arabized Islam ${ }^{31}$ and thus are infrequently on most modern Iranians' intellectual agenda anyway). 
The Ni'matu'llahis' khanaqabs in the West, which have from their inception in 1974 always been strongly Persianate in culture and ambience, went far in fulfilling their wishes and aspirations in this respect. Even Western initiates are currently encouraged to learn Persian (but discouraged from learning Islam's liturgical language, Arabic, towards which many Iranians have a historical aversion ${ }^{32}$ ). Etiquette, food and music in the khanaqabs are also completely Persian. Nearly every khanaqah in the West celebrates the Persian New Year (nawruz), while with the possible exception of the end of Ramadan ('aid-i fitr), few, if any, Islamic festivals or holidays are celebrated in the West, an adjustment to Western secular mores which may be contrasted with the traditional Shi'ite festivals of the birthday of Imam 'Ali and Qadir Qumm that are still very publicly celebrated by all branches of the Ni'matu'llahiyya in contemporary Iran. As for West Africa, the customs followed involve a blend of regional African, traditional Muslim, and Persian practices.

\section{Finances of the order}

Virtually all of the khanaqabs in the West are self-financing charities registered in the name of Khanaqah-i Ni'matu'llahi. Depending on the size of the building, each khanaqah building usually has a number of dervishes living in it, and since only one large room or two is used for the meetings, all those who live in the other rooms or apartments in the building pay rent, which is then collected and used to pay the khanaqah's generating expenses or for KNP publications or set aside in special accounts towards the purchase of new khanaqahs. Augmented by donations from wealthier members, enough money is collected in this fashion to establish new khanaqabs as a response to public interest. All KNP books are sold and distributed by the various khanaqabs, proceeds from which are then applied to help pay for the costs of new publications.

\section{The Ni'matu'llahi presence in cyberspace}

Shahram Khosravi has noted the uses of the public sphere of cyberspace for Iranians in their diaspora, which 'gives Iranians a chance to enter into and exit from public discussion anonymously', ${ }^{33}$ and Mark Bryson-Richardson has pointed out that 'Sufism forms a disproportionately large part of the Islamic presence on the Internet'. ${ }^{34} \mathrm{He}$ also underlines the 'extremely paradoxical' situation where 'in fighting the social force of modernity minority Sufi communities have chosen to fight with the tool of modernity itself and are therefore investing in the process of modernity'. ${ }^{35}$

The Ni'matu'llahiyya in the West have a website (www.nimatullahi.org) which gives a general definition of Sufism, followed by five categories of subject ('What is Sufism?', 'The Ni'matu'llahi Sufi Order', 'Dr Javad Nurbakhsh', 'Books and Magazines about Sufism', 'Ni'matu'llahi Sufi Centers around the World'), each of which carry their own subtitles that can be accessed separately. A choice of five languages is provided (English, Italian, Russian, Spanish, Swedish).

Thus, the English-language site 'What is Sufism?' has eight different rubrics, including 'Sufism', 'How is it possible to realise Perfection?' and 'Asceticism and Abstinence in Sufism'. Logging on to any of these subtitles, definitions of the various 


\section{Persian Sufism in the contemporary West}

subjects based on the writings of Dr Nurbakhsh come up. Each of these sites contains a great deal of detailed information about the Order, Dr Nurbakhsh, Ni'matu'llahi centres and publications.

\section{Persian publications of the Ni'matu'llahiyya}

The school (madhhab) of classical Sufism originated in Khurasan in northern Iran and from there was transmitted south-west to Baghdad. ${ }^{36}$

In 1988 Khaniqah-i Ni'matu'llahi Press in London began publishing a quarterly journal called Sufi in both Persian (subtitled Faslnama-yi Khanaqab-i Ni'matu'llabi) and English. To date (Spring 2002), fifty-three issues in each language have appeared, the journal having become the main organ of the Ni'matu'llahiyya in the West, reflecting the development and evolution of thought in the Order. In particular, over the 1990s, various articles appeared in the Persian issue of Sufi, revealing the full extent of the various transformations in attitude relating to the study of the relation of Islam and Sufism that have occurred. To illustrate these transformations, it will be useful to examine some of the views expressed in the recent Persian writings of Dr Nurbakhsh, before exploring similar perspectives found in various articles published in the last five years in the Ni'matu'llahi journal Sufi, dating back to 1996.

By way of attending to the needs of the increased numbers of Persian expatriate members unable to or uninterested in reading English, Dr Nurbakhsh, who is certainly the most prolific and intellectually formidable Persian Sufi master of the twentieth and twenty-first centuries, ${ }^{37}$ began to publish his books in Persian in England. (During most of the 1980s and 1990s, KNP publications had been banned by the censors in Iran.) Many of Dr Nurbakhsh's key English works (such as In the Tavern of Ruin and In the Paradise of the Sufis) were published in Persian-language editions during this period. Dr Nurbakhsh also has published in England and Iran between the years 1373 A.Hsh./1995 and 1378 A.Hsh./1999 a number of significant works in Persian on various great early Sufi masters. The stated intention of these works was to introduce the various founding fathers of Sufism to the burgeoning Iranian exile community in the West as well as his compatriots in Iran. In the author's forewords to each of these books, the relation of these masters to Persia and their Persian nationality is stressed, and their contribution in presenting the 'Iranianness' of the Sufi tradition is underlined.

Dr Nurbakhsh's thesis of the Persian origin of Sufism is most clearly expressed in his study of The Sufi Masters of Balkh, published in the year 2000, where the author affirms the innate Iranian nature and native Persian origin of Sufism, admonishing Iranians to follow Persian Sufi teachings because they are Iranian, and Sufism's humanistic universalism is explained as being a quintessentially Iranian cultural phenomenon. ${ }^{38}$ Even if such ethnocentric pronouncements may be balanced against other statements where he stresses inclusively that Sufism is a 'school that without regard to race and culture embraces all nations and creeds (milal $u$ nahal), ${ }^{39}$ it should be noted that during an international conference on Sufism at the School of Oriental and African Studies in London in 1997 he asserted categorically to a public audience of several hundred listeners that 
Western culture (farbang-i garb) and Eastern culture (farbang-i sharq) are two contraries. Western culture teaches you to 'Take care of yourself', whereas Eastern culture responds to this saying: 'Serve others and take care of them.' Therefore, a Western can never become a dervish (bichvaqt yek garbi darvish nimishavad $){ }^{40}$

When an Iranian lady in the audience objected that his assertion that Westerners can never become Sufis seemed to contravene the universalism of Sufism, he replied that

It [that assertion] is in fact, completely in accord with the essence of Sufism, because Sufis never speak in veiled terms. ... The problem is that it is difficult for Westerners to forget and forgo their egos for the sake of others. They cannot forget and renounce themselves for the sake of others, so how can it be expected that they should be able to forget themselves for the sake of God and divine Reality? In essence, forgetting oneself and sacrificing oneself for the sake of someone else is, according to the culture of the West, difficult; it's not impossible, but difficult. What my experience is, is that there are very many good people among the Westerners, but they come [to Sufism] to merely understand Sufism. It is difficult for them to become Sufis. ${ }^{41}$

When another Iranian member of the audience objected that the practice of Sufism belonged to all humanity (insaniyyat), rather than inhabitants of certain countries such as Iran, Dr Nurbakhsh gave his answer a political slant:

First of all, the discussion here doesn't concern humanity, but if we were to raise the question of humanity, then it should be stated that it is not humanity that the West should devour the Middle East and not allow the Middle East to take even a breath. ${ }^{42}$

In short, according to Dr Nurbakhsh, while Westerners prove themselves capable in appreciation and appraisal of theoretical aspects of Sufism, certain fatal cultural flaws within Western culture mean that they will 'never become' capable to realizing the tariqat in truth, in the actual practice ('amal) of Sufism. In other words, the metaphysical ubiquity of divine grace has been pre-ordained in pre-eternity as subject to certain innate physical and geographical restrictions, vouchsafed to mankind only within predetermined ethno-linguistic boundaries, outside of which there is no salvation.

Dr Nurbakhsh's stress on the Iranian origins of Sufism can be found both in the preface (pishguftar) to his monograph on Bayazid Bistami, composed in 1995, ${ }^{43}$ and in the introduction to his 1997 study of Abu Bakr al-Shibli (d. 945), entitled Shibli: the Ecstatic Mystic Intoxicated with God. Dr Nurbakhsh describes Shibli as deriving his Sufism from a specifically 'Persian culture'. ${ }^{44}$ In the first line of his 1999 monograph on Dhu'l-Nun al-Misri (d. 859), entitled Dhu'l-Nun al-Misri: one of the Notable Scholars and Sufis of Egypt, ${ }^{45}$ Dr Nurbakhsh underlines that Dhu'l-Nun al-Misri was a 'non-Arab', contrasting him to Bayazid who was inspired by ancient Persian wisdom (kay az hikmat-i khusravani ilham girifta bud), and 'had washed clean the pages of 


\section{Persian Sufism in the contemporary West}

intellectual learning with the wine of love and drunkenness, and so had even forgotten himself, traveling with the feet of God towards God'. ${ }^{46}$

Since 1990, many of the other Ni'matu'llahi Sufi disciples of Dr Nurbakhsh have also been articulating their faith in the light of Persian culture and ancient Iranian religious traditions. This process of what might be called the 'Persianization of Sufism' is quite visible in various articles written in Persian over the last ten years in the Persian issue of the quarterly journal Sufi which will now be examined.

Terry Graham, an American disciple of Dr Nurbakhsh who speaks and writes fluent Persian, has written a series of nine articles on eminent orientalists who had something significant to say about Persian Sufism, culture or literature, which were published in a special section of the journal dedicated to 'Servitors of Persian Culture' (Khidmatguzaran-i Farhanq-i Irani). Aside from providing the usual biographical details, the emphasis of these articles is to point out the contribution of the orientalist to Persian culture, and assess his merits and/or limitations in the understanding and expression of Persian Sufism, while underlining their specific advocation of the virtues of Persian culture and civilization. In chronological order, the eight figures covered to date are Axel Eric Hermelin, ${ }^{47}$ Edward Brown, ${ }^{48}$ Louis Massignon, ${ }^{49}$ Henry Corbin, ${ }^{50}$ Arthur Pope, ${ }^{51}$ Sir John Chardin, ${ }^{52}$ Ralph Waldo Emerson ${ }^{53}$ and Fritz Meier. ${ }^{54}$

One of the most interesting articles which struggles to interpret Sufism as an epiphenomenon of Persian culture is an essay by Dr Parviz Nawruziyan called 'Kay Khusraw's Crown on the Head of Shaykh Ishraq,',5 which connects the mystical persona of the Persian mythical king Kay-Khusraw depicted in Firdawsi's Shabnama with the notion of 'oriental illumination' in the philosophy of Shihab al-Din Yahya Suhrawardi (Shaykh al-Ishraq). Dr Nawruziyan relates the 'divine glory' (farr-i izadi) of Kay-Khusraw to Suhrawardi's celebrated doctrine of light. Although the article does not address the complexity of Suhrawardi's philosophical genealogy (which also may be traced to figures such as Hermes, Plato and Socrates, ${ }^{56}$ as well as ancient Persian prophet-kings and Sufi saints ${ }^{57}$ ), nor mention that Pythagoras and Plato are viewed by Suhrawardi as equally central to the history of philosophy as the Persians, ${ }^{58}$ he does stress the over-riding importance of the Khurasanian Sufi tradition on Suhrawardi, while omitting to take note of the philosophical context of the influence of his tradition on the Illuminationist master. ${ }^{59}$ Kay-Khusraw is portrayed as an Iranian prophet in the tradition of Sufi chivalry (javanmardi), ${ }^{60}$ a key representative of a Zoroastrian mystical chivalric order in the mythical 'Khusravani tradition (ayin- $i$ Khusravani)' into which one was initiated and became a disciple (murid), just as in Islamic Sufism. ${ }^{61}$ This mystical chivalric tradition was said to be transmitted by a lineage of sacred royal families, within whom the holy farr-i izadi was held to be preserved exclusively for all Iranians by Ahura Mazda until the Day of Judgement. ${ }^{62}$

In the second part of the article, the author cites and endorses the account given by the nineteenth-century Ni'matu'llahi master Zayn al-'Abidin Shirvani ('Mast 'Ali Shah') about the transmission of ancient Iranian philosophy to Suhrawardi from a lost Zoroastrian manuscript. ${ }^{63}$ Dr Nawruziyan asserts that the Sufi doctrine of 'trust in God' (tawakkul) is derived from Egyptian and Syrian Christianity, and claims the doctrine of activity and social exertion (kasb, 'amal) is derived from pre-Islamic 
Khurasan. ${ }^{64}$ The Islamic notion of asceticism ( $z u b d$ ), he states, is alien both to Suhrawardi and to the Shab-nama, which reflects a pristine pre-Islamic mysticism. ${ }^{65}$ Following Zarrinkub, who based himself on Richard Hartmann's theories about the Persian origins of Sufism, Dr Nawruziyan asserts that Khurasan is the cradle of Sufism, with Suhrawardi identified as the key master in the Khurasani tradition of Bayazid. ${ }^{66}$

Almost identical theories are advanced by Dr Nawruziyan in an article called 'Zoroaster and the Ancient Sages of Persia' ${ }^{67}$ and in an essay by Sayyid Muhammad Baqir Najafi that endeavours to prove that Firdawsi's Shabnama can be interpreted as expounding basic Persian Sufi doctrines. ${ }^{68}$ Both authors consider Firdawsi to be an advocate of Sufi doctrines, claiming that these doctrines ${ }^{69}$ have not only significant parallels but their full origins in Zoroaster's teachings. Dr Nawruziyan relies heavily on the researches of 'Abd al-Husayn Zarrinkub" ${ }^{70}$ to explain the pre-Islamic Persian origins of Sufism, and in order to support his thesis of the Zoroastrian origin of Sufism.

The limitation of the actual founding fathers of tasawwuf to the author's own Iranian compatriots is obviously in line with what Mehrzad Boroujerdi has termed 'the nativistic cult of authenticity' that 'often leads its partisans to develop a compulsive tendency to fetishise and celebrate difference'. ${ }^{71}$ Such ideas also recall what Massignon referred to as 'un enthousiasme "archéologique", which led certain chauvinist writers to celebrate the Shabnama as a 'breviary of Iranian nationalism'. ${ }^{72}$ Such views also typify a universalism typical of many New Age philosophies, in which the cultural and doctrinal context and historical specificity of the metaphysical formulations, technical language and terminology of the religion subject to comparison are but barely defined, and a new tradition is invented. ${ }^{73}$

A similar viewpoint is advocated by Karim Zayyani, who considers the tradition of Islamic chivalry (futuwwat) to have existed alongside (a non-Islamic type of) tasawwuf in ancient Iran for some 3000 years. In fact, he derives the historical origins of both futuwwat and tasawwuf from Khurasan, ${ }^{74}$ proclaiming: 'The intellectual pillars of the school of Sufism and Chivalry are, it is simple to see, grounded in Zoroastrianism. ${ }^{.75}$ Zayyani theorizes that the Ikhwan al-safa were an organized brotherhood based on the principles of Khurasani Sufi chivalry, which he says is proven by the fact that they declare that the true sage should be 'of Persian family lineage (farsi-nasab)', putting this as a subtitle in bold letters as if to underline the Iranian character of Sufism and chivalry. Since 'having a Persian origin is the basis of belonging to the Brethren of Purity', the author deduces that all true masters of chivalry must be Iranian. ${ }^{76} \mathrm{He}$ asserts:

So there is no doubt that Persian Sufism (tasawwuf-i Irani) originated in Khurasan, matured and developed, and then by way of the great Sufi masters, was taken from Khurasan to Baghdad. At the same time that Sufism was spreading in this fashion, the principles of chivalry were taken to Baghdad and Asia Minor, and thus the Ikhwan al-safa and Fityan appeared. ${ }^{77}$

In conclusion, in a large number of articles in the Persian journal Sufi, one finds a sort of revival of earlier theories proposed (but later rejected) in the nineteenth century by F. R. D. Tholuck in his Sufismus sive Theologica Persica pantheistica, that Sufism has 
a 'Persian Magian' rather than an 'Arab Islamic' origin. ${ }^{78}$ Similar theories that 'Sufiism is really the development of the Primaeval Religion of the Aryan race'79 were later expressed by E. H. Palmer in his Oriental Mysticism (first published in 1867), recast by the Dutch scholar Dozy (writing in 1879), who declared that 'mysticism came from Persia', ${ }^{80}$ finally reaching their greatest theoretical elaboration in an article on Sufism's origins published in $1916^{81}$ by Richard Hartmann, who asserted: 'It becomes clear beyond all dispute that sufism flourished first and foremost in Khorasan; indeed, it seems that we must regard as its cradle the eastern legacy of Khorasan. ${ }^{, 82}$

Other scholars went on to elaborate what might be called the 'Persian Aryan' theory, advocating the exclusively Persian origin of Sufism, which was disputed - and more or less definitively rebutted - by two scholars writing at the beginning of the twentieth century: R. A. Nicholson in his 1906 essay, 'A Historical Enquiry concerning the Origin and Development of Sufism, with a list of definitions of the terms 'sufi' and 'tasawwuf', arranged chronologically', ${ }^{83}$ and Louis Massignon in his Essai sur les origines du lexique technique de la mystique musulmane (1922). While Nicholson admitted that the 'pantheistic ideas' of Bayazid might be traced back to Persia and India, and that the theosophical element in Sufism was largely derivative from Greek thought, he argued that Sufism on the whole was the natural development of ascetic tendencies that can be found within Islam itself. Massignon's contribution was to prove definitively the centrality of the vocabulary of the Qur'an in the formulation and expression of Sufi technical terminology. He devoted several pages of his Essai to discussing the role of foreign, extra-Islamic influences on the development of Sufism, and specifically endeavoured to repute what he called 'the a priori thesis of Iranian influence' ${ }^{84}$

Massignon observed that if we adopt Ghazali's definition of mysticism as 'the practice of methodical introspection of religious experimentation and their results in the practicing believer, then cases of mysticism are bound to arise in every religious milieu where sincere and thoughtful souls exist'. Therefore,

Mysticism cannot thus be considered the exclusive apanage of one race, one language, or one nation. It is a human phenomenon which belongs to the plane of the spirit, and cannot be confined to those physical boundaries. Therefore, it is impossible to take at face-value the very widespread theory of pro-Aryans such as Gobineau, or of anti-semites such as Friedrich Delitzsch, who have pronounced that Semitic peoples absolutely lack the aptitude for the arts and sciences in general, concluding that there is an 'Aryan' origin of mysticism in the so-called Semitic religions. Such a theory naturally denies the authenticity of Islamic mysticism, and writes it off as a form of racial, linguistic and national reaction of the Aryan peoples, especially the Iranians, conquered by Arab Islam. Renan, P. de Lagarde, and more recently, Reitzenstein, Blochet and E. G. Browne have helped in the diffusion of this theory. ${ }^{85}$

Massignon rejects the thesis that identifies long lists of great Muslim thinkers as 'Persian' simply because their nisba refers to a city in present-day Iran. Such attributions, he argues, are 
... but a trompe-l'oeil: most of these thinkers thought and wrote only in Arabic, and whether they were sons of Arabic colonialists or clients (mawali), they were no more separate from the Islamic world than Lucan of Cordova or Augustine of Tagaste were from the Roman. ${ }^{86}$

While 'this theory pretends to be erected to the glory of the Iranian race', he underlines, 'it would lead us to an unconscionable disloyalty to its most illustrious representatives'.

This theory insinuates that great Muslim thinkers of Iran, contrary to their express declarations, only affiliated themselves to orthodox Islam for the sake of appearances, and that they laboured to twist and mold it to follow some narrow nationalistic bias. Such a pyschological explanation does not hold water for anyone who has held intimate converse with the works of these great men; no one had greater loyalty [to Islam] than Sibawayh in Arabic grammar, Isfahani in Arab folklore and Fakhr Razi in Koranic exegesis. Far from altering the purity of primitive Islam, these Persians went to great lengths of self-abnegation in the sacrifice of their personal tendencies in order to safeguard the universalism of their faith. And it would be presumptuous to pretend that they did not make a success of it. ${ }^{87}$

Contrary to these Western authorities on Sufism such as Nicholson and Massignon, a variety of writers in the Persian-language journal Sufi have proposed that Sufism is a purely native product of pre-Islamic Persian culture. Such views are not supported by most modern Western scholarship of Sufism (based squarely on the researches of Nicholson and Massignon) and instead are in line with earlier theories elaborated in the nineteenth and early twentieth centuries by Tholuck, Palmer, Dozy and particularly Richard Hartmann, who claimed to have found Sufism's origins in Khurasan in greater Persia. Tendencies towards 'sacred nationalism', as Ninian Smart defines it (see conclusion), ${ }^{88}$ thus seem to dominate the historical orientation of most of the contemporary writers $^{89}$ who have contributed to the Persian journal Sufi.

\section{English publications of the Ni'matu'llahiyya: 1974-2001}

The first English-language publications of the Ni'matu'llahi Order in the United States were small pamphlets describing the path and its practices printed in Tehran by the Khanaqah-i Ni'matu'llahi press. In 1978, the Order launched in the United States their own 'Khanaqah-i Ni'matu'llahi Publications', as a result of which these pamphlets were combined and published in two English-language volumes:

- In the Tavern of Ruin: Seven Essays on Sufism (New York, 1978, since reprinted five times and translated into French, German, Persian Spanish, Italian, Russian and Dutch).

- In the Paradise of the Sufis, devoted to the contemplative disciplines and spiritual practices of the Ni'matu'llahiyya (New York, 1979, since reprinted four times and published in French, German, Spanish, Italian and Russian translations). 


\section{Persian Sufism in the contemporary West}

Over the next two decades a further thirty-five titles were added to the Khanaqah-i Ni‘matu'llahi Publications (KNP) list. These included a series of monographs by Dr Nurbakhsh on important Sufi topics and themes, foremost of which may be mentioned:

- Sufi Women (New York, 1983, reprinted four times and since translated into Spanish, French, Italian and German).

- Jesus in the Eyes of the Sufis (London, 1983, reprinted once and since translated into Spanish, Italian and German).

- Dogs from the Sufi Point of View (London, 1989, since translated into Italian).

- Spiritual Poverty in Sufism (London, 1984, since translated into French, Italian and Spanish).

- The Great Satan, 'Eblis' (London, 1986, since translated into Italian and German).

- The Psychology of Sufism (London, 1992, since translated into Italian, German, Spanish and Russian).

Dr Nurbakhsh's two volumes of Prophetic traditions used by the Sufis, published in trilingual texts (Arabic, Persian and English), his five-volume work entitled The Gnosis of the Sufis (Ma'arif-i Sufiyya), and his fifteen-volume work on Sufi technical terminology entitled Sufi Symbolism (Farbang-i Nurbakbsh) remain his most significant contributions to Islamic Sufi studies in the West to date. In this context, it may be helpful to provide an outline of the two last-cited multi-volume works:

The five volumes on Sufi gnosis cover the following topics (by volume):

I Meaning, Knowledge and Unity;

II Fear and Hope, Contraction and Expansion, Gathering and Dispersion, Intoxication and Sobriety, Annihilation and Subsistence;

III Submission, Contentment, Absence and Presence, Intimacy and Awe, Tranquility and Serenity, Fluctuation and Stability;

IV Repentance, Abstinence, Renunciation, Wariness, Humility, Humbleness, Sincerity, Constancy, Courtesy;

V Gratitude, Patience, Trust-in-God, Aspiration, Veracity, Zeal, Valour, Altruism, Shame.

The monumental fifteen-volume work Sufi Symbolism (translation of which often unfortunately tends to be literal rather than literary) is devoted to the symbolic and theosophical vocabulary in Sufi poetry, covering the following rubrics according to individual volume:

I Parts of the Beloved's Body, Wine, Music, Sama and Convivial Gatherings;

II Love, Lover, Beloved;

III Religious Terminology;

IV Symbolism of the Natural World;

V Veils and Clothing, Government, Economics and Commerce, Medicine and Healing;

VI Titles and Epithets; 
VII Contemplative Disciplines, Visions and Theophanies, Family Relationships, Servants of God, Names of Sufi Orders;

VIII Inspirations, Revelations, Lights, Charismatic Powers, Spiritual States and Stations, Praise and Condemnation;

IX Spiritual Faculties, Spiritual Organs, Knowledge, Gnosis, Wisdom and Perfection;

X-XII Spiritual States and Mystical Stations;

XIII Scribes, Pens, Tablets, Koranic Letters, Words, Discourse, Speech, Divine Names, Attributes and Essence;

XIV The Unity of Being;

XV Mystical Terminology.

Two volumes of his own poetry have also been published in English: The Truths of Love and selections from his Divan. Dr Nurbakhsh's poetry has appeared on several CDs produced by members of the Order during the 1990s. ${ }^{90} \mathrm{Ni}$ 'matu'llahi Sufi teachings have also filtered into the mainstream of modern American literature and art. The acclaimed American National Book Award-winning poet Robert Bly dedicated his most recent book of poetry (ghazals written in English) to Dr Nurbakhsh, ${ }^{91}$ while the second chapter of his The Sibling Society, ${ }^{92}$ a book of social criticism of modern American culture, relies heavily on Dr Nurbakhsh's The Psychology of Sufism. The celebrated American abstract expressionist painter Wallace Putnam (1899-1989), ${ }^{93}$ who converted to Ni'matu'llahi Sufism during the last decade of his life, painted several large canvases devoted to classical Sufi themes, ${ }^{94}$ then willed his entire estate to the Order upon his death.

\section{Conclusions: Transformations of Ni'matu'llahi Sufism in the West (1979-2001)}

Righteousness does not consist in turning your face toward the East or the West. (Qur'an II: 177)

As can be seen from the above study, the Persian Ni'matu'llahi Sufis do not live in a world entirely isolated from social and political developments. If anything, they are more aware of and more sensitive to social injustices and cultural backwardness than other Sufi groups. The life of the spirit is only one, albeit the central, part of the Sufi's life, but the Sufi lives like every other member of society subjected to the ills, malaise and profanation, as well as the well-being, prosperity and re-enchantment, of the community. Consequently, the spiritual attitudes of Sufis are not only not independent from socio-political concerns and events, but are often causally influenced by them in a very direct manner. The direction towards which Iranian popular culture seems to be evolving is modernization and secularization ${ }^{95}$ and so certain modernist and secularist values have inevitably found expression in contemporary Western Ni 'matu'llahi Sufism.

One such secular value is nationalism. Ninian Smart has drawn attention to the similar factors which nationalism shares with religion, proposing that the study of 


\section{Persian Sufism in the contemporary West}

'sacred nationalism' should be considered as 'integral to the modern exploration of religion'. ${ }^{96}$ Although nationalism is not a significant factor (or even an existent notion) in traditional Sufism, ${ }^{97}$ since the terms 'nation' (millat) 'homeland' (watan) and 'country' (kishwar) had completely different political and geographical connotations in medieval times than they do today, many examples of syncretism and blending of the transcendental doctrines of Sufism with nationalist ideologies can be found in the recent history of the Middle East. Nationalism has often been used as a weapon to combat Sufism (as with the abolition of the Orders in Turkey under Ataturk in the name of defence of the values of secular nationalism), just as Sufism has occasionally been press-ganged in support of nationalism (as with Z. A. Bhutto's claim that Sufi saints were forerunners of the modern Islamic state of Pakistan). ${ }^{98}$ In this context, what might be (tentatively) termed the sacred nationalistic ${ }^{99}$ perspective adopted by the authors in the Ni'matu'llahi Order's Persian journal Sufi examined above reflects what Mehrzad Boroujerdi has termed 'orientalism in reverse'.

First and foremost, orientalism in reverse uncritically embraces orientalism's assumption of a fundamental ontological difference separating the natures, peoples and cultures of the Orient and the Occident. Orient and Occident are depicted as essentialistic geographical, historical and cultural entities asymmetrical to one another. Each is supposed to possess its own distinct and easily identifiable history, imagery, tradition of thought, mode of discourse, ethics and culture. Implicit in this abstractness that construes Orient and Occident as the irrevocable others of one another is an assumption about the homogeneous compositions of each other's inhabitants and territories as if they are all concrete, conscious and undifferentiated totalities and terrains. ${ }^{100}$

In their occidental diaspora, the Ni'matu'llahis thus hearken back to national mythologies based on the Shahnama and native ethical doctrines derived from the futuwwat tradition. While it is true that the cultural development of Islamic spirituality owes much to Iranian Islam and to Persianate Sufism, ${ }^{101}$ the Ni'matu'llahis have returned to what is held to be the primordial, and often pre-Islamic, sources of mystical truth - Persian national mythology, native ethical systems (javanmardi, chivalry) and the 'heavenly atmosphere' of Persian Sufi poetry. ${ }^{102}$ It is hard to know if such an ethnocentric understanding of Sufism as a manifestation of a specifically Persian culture might be part of the on-going ideological battle against the intellectual marginalization ${ }^{103}$ and cultural disenfranchisement of Sufism in the Islamic Republic of Iran. The attraction of Western members of the Order, on the other hand, seems to be to Sufism's universalism and broad-minded ecumenical perspective, and for them such nationalistic values based on native Persian mythology and religion have little or no resonance.

No doubt, however, the ultimate spiritual source of Ni'matu'llahi teachings lies beyond these historical debates and controversies. The Sufi's soul, which looks on that which does not change: the One, the unborn, the undying, knows neither East nor West. The mystic rose of Islamic tasawwuf sprouts from an earth which is neither in Persia, Arabia, India nor America. The light of God has neither birthplace, terrestrial 
abode nor address, as Rumi says. ${ }^{104}$ Spirituality transcends nationality, and is the stock-in-trade of neither Arabs nor Persians, for the longings and belongings of foreign and familiar geographical climes have never determined the communio sanctorum of which Khidr is the eternal guide.

Whether they hail from Baghdad, come of Ray - or from Herat,

the Sufis are all the Prophet's kin beyond their bodies.

A rose is still a rose no matter where it grows;

The vat of wine only ferments wine - wherever the vat is put it boils fine.

If the sun should raise its head from the West

it's just the sun

- naught else. ${ }^{105}$

\section{Notes}

1 I am deeply indebted to the kind assistance of Terry Graham, Paul Weber and Neal Johnston for reviewing and providing many useful suggestions about the structure and content of the present article.

2 Marcia Hermansen (2000), p. 158.

3 Use of the adjective 'Ni'matu'llahi' in this chapter refers to this branch alone. Neither of the other two main branches of the modern-day Iranian Ni'matu'llahiyya (the Safi 'Ali Shahi, and the Sultan 'Ali Shahi [or Gunabadi] branches) have had a significant numerical presence or reputation outside of Iran, although the Gunabadi branch within Iran is by far the largest and best known of the three branches. See L. Lewisohn (1999b), p. 36-59.

4 Some 35 books, including two large multi-volume encyclopaedias, have been published in English translation alone; one could easily devote a long article exclusively to presentation and discussion of the literary activities of this branch of the Ni'matu'llahi Order over this period (a summary of which is given below).

5 Mir Husayni Sadat, Nuzhat al-arwah (Spirits' Delight), (ed.) Najib Mayil-Haravi (Mashhad: Intisharat-i Kitabfurushi Zawwar, n.d.), p. 23.

6 Carl W. Ernst (1997, p. 214) remarks: 'Many examples could be cited of conflict between fundamentalists and Sufis over the past two centuries, from the Indonesian dakwa movements to the persecution of Sufi orders in revolutionary Iran. One of the early examples was the series of debates held by Shaykh Ahmad ibn Idris, an extremely influential Sufi reformer in North Africa ... This kind of debate has continued to shape the lives of Muslims ever since.'

7 See Terry Graham (1999a), pp. 173-190.

8 Ibid., p, 185.

9 Terry Graham (1999b), III, p. 173.

10 Ibid., p. 167.

11 For a good discussion of which, see Terry Graham (1999b), pp. 173ff.

12 Ibid., p. 178.

13 N. Pourjavady and P. L. Wilson (1978), p. 93; Hamid Algar, s.v. 'Ni'mat-Allahiyya'; in Encyclopedia of Islam, 2nd ed., pp. 44-48. 


\section{Persian Sufism in the contemporary West}

14 For an account of which see part one of Lewisohn (1999b), pp. 36-59.

15 Shirazi, Tara'iq, III, pp. 299-317.

16 On the various branches and recent history of this order, see Lewisohn (1999b).

17 Ibid., part 1.

18 The best general overviews of the history and doctrines of the Ni'matu'llahi Order (up to 1978 and 1990, respectively) are: N. Pourjavady and P. L. Wilson (1978), and Javad Nurbakhsh (1991), pp. 144-161.

19 The advent of the 1979 revolution in Iran provoked his departure. Centuries of historical animosity between mullah and Sufi, along with the 53 years of the Pahlavis' semi-secular rule, had done little to lessen the 'Usuli Shi' ite clergy's hatred of Sufism. Add to this the frequent assassination and constant persecution of Dr Nurbakhsh's spiritual forebears among the Ni'matu'llahiyya (there was a long tradition in Iran of pogroms, witch-hunts and murders of numerous Ni'matu'llahi shaykhs and masters in the nineteenth century), the inevitability of the current Western diaspora is apparent.

20 Interview with stewards of East-coast American Ni'matu'llahi khanaqahs, May 2001.

21 This is made clear in his essay 'Master and Disciple' in his In the Tavern of Ruin: Seven Essays on Sufism, pp. $129 \mathrm{ff}$.

22 In the Paradise of the Sufis (1979), since reprinted four times.

23 It was only in 1991 that Dr Nurbakhsh first appointed a series of shaykbs for the khanaqabs in the West.

24 'The Sufi is no one. How can "no one” be defined?' (Nurbakhsh 1981, p. 41.)

25 See Nurbakhsh (1989), pp. 118-125.

26 As W. C. Chittick states rightly: 'Javd Nurbakhsh's ... perspective falls on the side of intoxication.... He pays little attention to the shari'ah, but he discusses the importance of Sufi communal activities such as sessions of dhikr.' 'Sufi Thought and Practice', in J. Esposito (ed.) (1995), IV, p. 108

27 See Nurbakhsh (1994), pp. 17-19. While there is also an English translation of this work (by 'Alireza Nurbakhsh) entitled Discourses on the Sufi Path (1996), all references below are to the Persian text.

28 Chibil kalam u si payam, p. 124.

29 The basic irrelevance of gender segregation in Ni'matu'llahi spirituality is reflected in Dr Nurbakhsh's discourse on the rules and manners of dervishes in the khanaqah, where he remarked that the dervish should never notice who he or she is sitting next to when meditating in the khanaqah, so that 'when the Sufi leaves the Khanaqah, and someone asks who he or she saw there, the response should always be that "I remember seeing no one, I was not aware of anyone there".' Chibil kalam u si payam, p. 113. Likewise, he points out that 'Sufism does not consist in wearing black gowns or white robes. The Ni'matu'llhi dervish should not, through wearing a special dress or robe, stick out in society, for the land of men is the valley of the heart, not in this material ground of mud and mire.' Ibid., p. 140.

30 Dr Nurbakhsh stipulated in his essay 'Rules and Manners of the Khanaqah' that 'A sufi should not object to the behaviour of another sufi, or wonder about the "whys" and "hows" of another's actions. The personal freedom of every dervish must be observed and respected in the Khanaqah. One should not interfere in anyone else's business, for each sufi has his own way, state, rapture, and universe.' In the Tavern of Ruin, pp. 81-82.

31 For the recent historical background of anti-Arab, anti-Islamic sentiments in Iranian society, see Shahrukh Miskub (1994) where he points out (p. 487) 'that anti-Arab and sometimes anti-Islam sentiments and Persian nationalism frequently go hand in hand in many modern Iranian intellectual world-views.'

32 On the contemporary history of anti-Arab feelings and pro-Persian chauvinistic rhetoric among Iranians, see Joya Blondel Saad (1996); Mostafa Vaziri (1993), pp. 161-162, 192-197, 207.

33 Shahram Khosravi, 'www.iranian.com, An Ethnographic Approach to an Online Diaspora', (VI, Oct. 2000), p. 13. 
34 'Cybertariqas: Sufism in the Diaspora, Identity and Virtual Community', Islamica, III/1 (1999), p. 75.

35 'Cybertariqas', p. 77.

36 From Dr Nurbakhsh's Foreword to L. Lewisohn and David Morgan (eds) (1999a), p. xxv.

37 Back in the 1960s Henry Corbin (1964, p. 434) had thus referred to Dr Nurbakhsh's 'prodigious activity' in publishing and khanaqah construction.

38 In its foreword, he writes: 'The reason why I set out to compose and publish the present work, The Sufi Masters of Balkh, which includes studies of these masters (Ibrahim ibn Adham, Shaqiq Balkhi, Khatim-i Assam, Ahmad Khadruyya, Muhammad ibn Fadl Balkhi), is so Iranians might become better acquainted with the great trail-blazers of the Sufis, and also that they may realize that cradle of the world's Sufism and the gnosticism (khastgah-i tasawwuf $u$ 'irfan-i dunya) was in Greater Khurasan, and understand that this humanist school is Iranian (in maktab-i insani irani ast).... In this fashion, it may be that the nation of Iran (millat-i Iran) will better appreciate the value and degree of their own culture and literature, and choose to follow their way and tradition, so that the torch of this humanistic school may day by day grow brighter.' (Nurbakhsh 2000.)

39 Nurbakhsh, Chibil kalam u si payam, p. 32.

40 Translation from an audio cassette in the SOAS archives from the conference 'Persianate Sufism in the Safavid and Mughal Period', (May 19-21, 1997).

41 Ibid.

42 Ibid.

43 In its foreword, he writes: 'Bayazid undertook to establish a humanist school of thought (maktab-i insaniyyat) under the banner of mysticism ('irfan) during a time when Iranians were engaged and preoccupied in the struggle against the alien culture [of the Arabs] (mubariza-yi farbang-i bigana). With his creatively original words he managed to preserve and protect Iranian culture from the influence of foreigners [i.e. Arabs].' (Nurbakhsh 1995, p. 4.)

44 'Shibli was one of the great masters of the Sufi Path of the fourth (tenth) and the beginning of the fifth (eleventh) century. Since he was of Persian derivation (aslish Irani bud) and spent some time in Iran as an official holding a post with the government of his day, he became acquainted with the philosophy and the ethics of the Persians (ba falsafa va akblaq-i Irani), which consists of the unity of being (wabdat-i wujud), love of God and divine Reality ("ishq bi-Haqq va haqiqat), chivalry and kindness to all living beings, and thus the primacy of this persuasion convinced him to abandon the vanities of the transient world and to totally devote himself in humble supplication to the court of the He who has no needs.' From the preface (pishguftar) by J. Nurbakhsh to his monograph Shibli: Mast-i Haqq va majdhub-i haqiqat (1997), p. 3. Italics mine.

45 Nurbakhsh (1999b).

46 Nurbakhsh (1999b), preface. The author's emphasis on the 'non-Arab' identity of Dhu'lNun seems to derive from the fact that his father was a native of Nubia in Upper Egypt, a freed slave who was adopted by the tribe of the Quraysh. While R. A. Nicholson (1906, p. 309) described Dhu'l-Nun as 'the man who, more than any other, deserves to be entitled the founder of theosophical Sufism', the author of the first definitions of wajd and sama (p. 310), and the mystic who 'above all others gave to Sufi doctrine its permanent shape', (p. 311) and Massignon (Essai, p. 208) cites him as the first mystic to single out the notion of ma'rifa in Sufism, this differs from the role assigned by Dr Nurbakhsh to Dhu'l-Nun. (Actually, no Western orientalist's works, such as Massignon Essai, appear in the bibliography of Dr Nurbakhsh's work on Dhu'l-Nun). Citing the name of the famous Sufi woman saint Fatima Nayshaburi (d. 223 A.H./837-8), with whom Dhu'l-Nun was on intimate terms, Dr Nurbakhsh reflects (1999b, p. 21) that it is possible Dhu'l-Nun learned the customs of chivalry and knightliness and self-sacrifice belonging to the Sufis of Khurasan from Fatima Nayshaburi'a, in this fashion giving him an honorary Iranian identity through association with this Persian female saint. (Indeed, most of the historical sources that treat 


\section{Persian Sufism in the contemporary West}

Dhu'l-Nun's relationship with Fatima Nayshaburi have stressed her deep effect on his teachings. See, for instance, Ibn 'Arabi [1988], introduction, pp. 21-22; text, pp. 236ff.)

47 Anush Tawzi', ed. Mustafa Shafafi, Sufi, no. 36 (1376 A.Hsh./1997), pp. 21-23.

48 Sufi, no. 38 (1377 A.Hsh./1998), pp. 17-21.

49 Sufi, no. 40 (1377 A.Hsh./1998), pp. 20-23.

50 Sufi, no. 40 (1377 A.Hsh./1998), pp. 21-23.

51 Sufi, no. 42 (1378 A.Hsh./1999), pp. 14-17.

52 Sufi, no. 43 (1378 A.Hsh./1999), pp. 15-18.

53 Sufi, no. 46 (1379 A.Hsh./2000), pp. 15-23.

54 Sufi, no. 47 (1379 A.Hsh./2000), pp. 22-25.

55 Parviz Nawruziyan (1997a \& 1997b).

56 As Nasr puts it: 'From the Ishraqi point of view, Hermes or the Prophet Idris is the father of philosophy, having received it as revelation from heaven. He was followed by a chain of sages in Greece and in ancient Persia and later in Islam which unified the wisdom of previous civilizations in its milieu.' S. H. Nasr (1995), I, p. 376.

57 On which, see John Walbridge (2000), pp. 30-31. Henry Corbin notes: 'The ecstatic heroes of this "Oriental theosophy" of Light are Plato, Hermes, Kay-Khusraw, Zarathustra, Muuhammad: the Iranian prophet and the Arab prophet' (Corbin 1969, pp. 20-21).

58 The discussion given of the Greek element in Ishraqi thought in the article is cursory and limited to a mere paragraph (see part 1, p. 26).

59 When, in a short work on epistemology, Suhrawardi relates his dream of Aristotle extolling the spiritual rank of Plato, he was also surprised to hear Aristotle heap praise on the Sufis: Abu Yazid al-Bistami and Sahl al-Tustari as 'the true philosophers.' See Walbridge (2000), Appendix II.

60 Dr Nawruziyan, 'Taj-i Kay Khusraw', part 1, p. 28.

61 Ibid., p. 29. The most recent work on this mythical tradition is Hisham Radi's: Hikmat-i khusravani: hikmat-i ishraq u'irfan az Zartusht ta Subrawardi (1379 A.Hsh./2000), which also advocates the idea (see pp. 186-88) that all of Sufism and even Platonic tradition can be traced back to purely Persian Zoroastrian teachings.

62 Ibid., p. 29

63 Dr Nawruziyan, 'Taj-i Kay Khusraw', part 2, p. 32-33. Shirvani, Bustan al-siyahat (1315 A.Hsh./1936), p. 98.

64 Dr Nawruziyan, 'Taj-i Kay Khusraw', part 2, p. 26.

65 Ibid., p. 26.

66 Ibid., p. 33.

67 Parviz Nawruziyan (1379 A.Hsh./2000), pp. 12-18.

68 Najafi (1379 A.Hsh./2000), pp. 6-15.

69 Dr Nawruziyan ('Zartusht ...', pp. 14-17) claims that the origins of the Sufi doctrines of worship of one God, the divine invocation of all atoms of the cosmos, gnosis, the 'greater holy war' against the ego, continuous remembrance of God (( $d b i k r)$, and divine love ('ishq) can all be traced back to the Gathas of Zoroaster.

70 Zarrinkub (1357 A.Hsh./1978), chapter 2. Zarrinkub's opinions are unfortunately cited out of context quite often. Thus, in the introduction to the article, Dr Nawruziyan ('Zartusht ...', p. 12) cites Zarrinkub as having stated that 'Zoroaster was an ancient Iranian Sufi', whereas Zarrinkub (Justuju, p. 23) had only compared the artistic and inspiritional nature of the author of the Gathas to that of 'an old Iranian Sufi poet.' In his conclusion, Dr Nawruziyan (p. 18) again cites Zarrinkub (out of context, in order to glorify the legacy of Zoroaster over that of Muhammad): '... without the aqua vita of this (Zoroastrian) tradition, Islamic Sufism would perhaps never have taken root in Iran, and if it had taken root, it would never have produced works of the profundity and glory of Ghazali, 'Ayn al-Qudat, Rumi and Shabistari'. Zarrinkub's complete sentence is considerably more nuanced and fairminded in its appreciation of the Islamic origins of Sufism: 'Islamic Sufism, although it is based squarely on the Qur' an and the Sunna, over the course of the first few Islamic centuries was also subject to influences from which flowed in the 
intellectual and religious currents which existed in the Mazdean heritage of the late Sassanian period. These influences aided Sufism to gradually mature and perfect itself, and indeed, without the aqua vita of this tradition, Islamic Sufism would perhaps never have taken root in Iran, and if it had taken root, it would never have produced works of the profundity and glory of Ghazali, 'Ayn al-Qudat, Rumi and Shabistari' (Justuju, p. 22).

71 Mehrzad Boroujerdi (1996), p. 18.

72 Massignon (1954), p. 65.

73 In his monumental study New Age Religion and Western Culture (1998), pp. 324-325, Wouter J. Hanegraaf points out how the 'New Age approach seems to exemplify a phenomenon known as the "invention of tradition".' The phenomenon was first defined by Marian Bowman in her discussion of New Age reconstructions of Celtic culture, her observations may also be applied in the present context. She observed 'a need to root present beliefs and practices in the past, linking them with previous groups of enlightened people .... By sharing a particular view of the past, people belong to a community, no matter how loosely constituted. The attraction to being heir to an esoteric is immense. By knowing what 'really' happened, the past serves to justify one's present beliefs and practices' (Bowman 1993, pp. 147-156).

74 Karim Zayyani (1380 A.Hsh./2001), p. 27.

75 Zayyani, 'Javanmardi ...', p. 27.

76 Zayyani, 'Javanmardi ...', p. 31.

77 Zayyani, 'Javanmardi ...', p. 32. It should be emphasized that none of the celebrated scholars who have researched the origins of the Ikhwan al-safa, such as Samuel Stern, V. Ivanov, Casanova, Y. Marquet, Ignaz Goldziher, or H. F. Hamdani, has uncovered even one solid piece of evidence to support Zayyani's thesis of their Persian origin. The religious syncretism and eclecticism of the 52 treatises in the Ikhwan al-safa corpus is extremely broad, containing doctrines found in Hermetic, Pythagorean, Sabean, Greek, Christian, Jewish, Buddhist, Hindu, Isma'ili, and Neoplatonist philosophy. Amid these currents, the Sufi element is but a small and incidental strand. (See Ian Netton 1982, p. 50.) The idea that they were solely an offshoot, or even incidentally related to the chivalric tradition of Khurasan not only has no scholarly basis, it has never even been suggested by any scholar to date as having been a significant formative influence in their composition (cf. Y. Marquet, 'Ikhwan al-Safa' Encyclopedia of Islam, 2nd ed., III, pp. 1071-1076).

78 Tholuck attributed Sufism to the Persians, and under the influence of racial theory, formulated that famous 'Aryan reaction' theory: that it consisted of an Aryan gnosticism pinned on to the legalist tendencies of the Arab Semites. See Carl Ernst (1997), pp. 15-16.

79 E. H. Palmer (1867), p. 11; cited by A. J. Arberry, op. cit., p. 23.

80 A. J. Arberry, (1992), p. 25.

81 Der Islam, VI (1916), pp. 31-70.

82 Der Islam, VI, 31. A. J. Arberry, op. cit., p. 36.

83 Journal of the Royal Asiatic Society, Part I, 1906, pp. 303-353.

84 L. Massignon (1954), pp. 63-68.

85 Massignon (1954), p. 64.

86 Massignon (1954), p. 65.

87 Massignon (1954), pp. 65-66.

88 'Sacred Nationalism', 40th Anniversary Lecture of the British Association for the Study of Religion (Leeds: BASR Occasional Paper, n.d.).

89 All of the authors of the articles cited above are also initiates of the Order, a few of them high-ranking.

90 These include Wine of Sincerity: Sufi Music of Iran by Davod Azad (composer, tar, tanbur, setar and vocals), with F. Kiani and H. Pourmehdi (tombak, daf) (Los Angeles: KNR 1996); Quest by Amir Khoushkani \& Houman Pourmehdi (Vancouver, Canada: Songlines 1998); and In the Name of the Beloved (Original Persian and Flamenco Mystical Music): Sufi Poetry by Dr Nurbakbsh performed by David Felthouse (guitar and Flamenco vocals), 


\section{Persian Sufism in the contemporary West}

Houman Pourmehdi (tombak, daf, ney), Mahshid Mirzadeh (santur), Khusro Ansari (Persian vocals), Pirayeh Pourafar (tar) (Los Angeles: Lian Records 1998).

91 Robert Bly (2001).

92 Robert Bly (1996), pp. 25ff. and notes on p. 250.

93 See Francis Naumann (2002).

94 One of which ornaments the cover of this book.

95 Although the ongoing religious resurgence in the Middle East and revival of religion in the world at large which is convincingly presented in Peter Berger's (ed.) (1999) cannot be ignored, the process of the 'secularization of culture' in Iran, contrary to the predictions of some sociologists (e.g. S. A. Arjomand 1988, p. 91) is still continuing in full swing (for a good discussion of which see Mahmoud and Ahmad Sadri 2000, pp. xvi-xix). Of course, one must distinguish in this process 'objective secularization' which is intended here - from 'subjective secularization' or profanation.

96 'Sacred Nationalism', p. 8; and idem., Ninian Smart (1989), introduction.

97 On the conception of the term 'homeland' (watan) in classical Persian Sufism, see Muhammad Rida Shafi'i-Kadkani (1989), pp. 8-10. On the changes undergone by these terms in Iranian nationalist discourse during the last three centuries, see Mohamad Tavakoli-Targhi (2001), chap. 7.

98 Ernst (1997), pp. 79, 209.

99 Ninian Smart points out: 'Because pure nationalism is so feeble metaphysically, it reaches usually for a metaphysic .... We may say that while nationalism is itself a religion, it acquires a doubly negative religious character through its history's being itself interpreted in a traditional religious light.' 'Sacred Nationalism', pp. 3-4.

100 Mehrzad Boroujerdi (1996), p. 12. Also see Bradford Verter (1998), pp. 557-561.

101 See my 'Overview: Iranian Islam and Persianate Sufism', in L. Lewisohn (ed.) (1999a), pp. $11-43$.

102 S. H. Nasr's term, used in his article 'Persian Sufi Literature: Its Spiritual and Cultural Significance', in L. Lewisohn (ed.) (1999a), p. 6.

103 On the marginalization of Sufism in modern Iranian intellectual life, see L. Lewisohn (1999b), part 1, pp. 55-57.

104 See Rumi's Mathnawi, ed. R. A. Nicholson (1924-40), IV: 1039.

105 Ibid., VI: 187-89. 


\title{
3 The evolution of the Naqshbandi-Mujaddidi
}

\author{
Sulaymançis in Germany
}

\author{
Gerdien Jonker
}

This essay focuses on the issue of Sufic devotion in Muslim communities that once belonged to traditional Sufi orders, but nowadays no longer consider themselves to form part of them. Turkish Muslim organizations that dominate Muslim life in Europe offer themselves for a case study. Milli Gorüş, Nurçu and Sulaymançi all descend from the Naqshbandi Order, but in the course of the twentieth century they came to embrace different organizational principles and religious foci. For the past four years, I have studied forms of collective memory and religious communication among the Sulaymançi in Europe. ${ }^{1}$ More recently, I have carried out fieldwork in Milli Gorüş mosques. It is my argument that these organizations constitute Sufic lay communities, holding on to Sufic devotion while refocusing on worldly religious aims.

After giving an overview of Sufi orders in Germany, I will focus on the Sulaymançi organization and proceed with an outline of the concept of the Sufic lay community. My access to the field has been largely historical. I collected strands of collective memory in Sulaymançi communities and compared them with the findings of historical research. This approach has allowed me to describe the choices that had to be made in order to turn the Order into a modern missionary apparatus. Religious systems are not primordial entities. Rather, through the handing down of a corpus of rites, narratives and texts, they offer a breeding ground for the creation of religious communication. Just like political systems, religious systems can produce new constructions and selective (re-)imaginings to respond to changing institutional expectations, and they do this both on a local and a global level. ${ }^{2}$ Theology is one of the classic pathways through which the religious past is re-imagined and constructed anew. However, crucial to the evolution of the Naqshbandi Order has been the recentring of its main religious forms of communication, such as the rite of remembrance and the imitation of the Prophet. In this contribution, I will focus on the latter. Finally, I will sketch out how the Sulaymançi nowadays perceive Sufic devotion in a traditional Naqshbandi Order - and thoroughly disapprove of it.

\section{The hidden presence of Sufi orders in Germany}

Recently, some of the Sufi orders with centres in Germany have established their own websites. This electronic presence includes up to now two Sunnite and two Shi'ite Khaniqat. Of these two, the Naqshbandi-Haqqani are based in the countryside near 


\section{The evolution of the Naqshbandi-Mujaddidi}

the Belgian border ('The Ottoman Inn'), whereas the Mevlevi have found a home in Trebbus, a small village in the eastern federal state of Brandenburg just south of Berlin. The US-based Ni'matu'llahi have set up a branch in Cologne, and the similarly US-based Maktab Tariqat Oveyssi Shahmagsoudi can be found in Frankfurt, Düsseldorf, Stuttgart and Hamburg. Also present on the web are neo-Sufic organizations such as the 'Universal Sufism' founded by Vilayet Inayat Khan, as well as a series of what have been coined 'links with a Sufic background', the latter leading to a mixture of new age therapies, shamanism, musical performances and artistic endeavours. The search is facilitated by the private home pages of a handful of German Sufi enthusiasts, who have assembled the few existing German-language links together with titbits of historical information, music, poetry and samples of Sufi folklore. ${ }^{3}$

Although these home pages also offer some information on orders that are based in Europe but do not have websites, such as the Tijani in Basel, the majority of Sufi orders in Germany remain largely invisible. This invisibility has a history that is intimately connected with the exclusion of Muslims from the German public sphere. Muslim organizations and Muslim devotion are generally treated with suspicion, and some leading German magazines regularly publish articles depicting Sufism as a political undercover organization. ${ }^{4}$ Sufism in Germany has also been neglected as an academic topic. In the past twenty years or so, no research has been carried out to describe different forms of religious communication or organizational readjustments to institutional expectations. Even the attempts to present an overview of Sufism in Germany have remained rather superficial.

Abdullah Halis Dornbrach, shaykh of the Mevlevi Order in Trebbus, published a slim booklet on the Islamic orders in Germany in 1991..$^{5}$ All in all, he mentions eleven Sunni and Shi'i orders. Among the former he counts the Naqshbandi, Qadiri, Rifa 'i, Mevlevi, Cerrahi, Burhani, Darqawi, Safini and Alawi. The latter comprise the Ni‘matu'llahi and Bektashi. Dornbrach also classifies as Sufi orders those Turkish Muslim organizations that have descended from individual Naqshbandi preachers, and he explicitly mentions the Sulaymançi. His brochure generally serves as a point of reference for scholarly descriptions. ${ }^{6}$ Other authors have added to this list some centres of Chishti, Shadhili and Tijani orders, as well as other Turkish Muslim organizations descending from Naqshbandi preachers, among them the Nurçu and the followers of Fethullah Hoca' ${ }^{7}$ Nevertheless, some of the authors have decided to neglect what they call 'foreign Sufi orders' altogether and have concentrated on 'native Germans' instead. ${ }^{8}$ Thus, additional information on Burhani, Mevlevi, NaqshbandiHaqqani and Alawi has been gained, as European converts dominate these orders. However, the information offered in these writings never goes beyond the frame of a short description. In addition to the - scarce - literature on Sufism in Germany, the Christian-Islamic dialogue journal CIBEDO offers space for Sufic self-representations, and during the last few years some orders have made sparing use of this.? As yet, problem-oriented research that looks at, for instance, societal bases and recruitment patterns, transnational networks, modes of female participation or the tension between charisma and institutionalization has hardly been undertaken. ${ }^{10}$

Over the past decades, Sufi centres kept a low profile for fear of bad publicity, trying hard not to attract any public attention. The orders that went online in 2000 and early 
2001 thus represent a novelty in more than one respect. They strive for transparency while offering a complete picture of the history, genealogy, teachings, poetry and musical traditions, as well as presenting courses and prayer instructions of their order. The Mevlevihane, which has produced by far the largest and most beautiful site, also offers a reading room, a book shop, an encyclopaedia, a virtual museum of Mevlevi artefacts, a photo gallery and a site map of its topography. In this way, it has managed to make life in the Sufi community accessible to public knowledge.

Apart from these orders, Muslim organizations that stem from initiatives of individual Naqshbandi preachers have also set up shop on the web. Approached from history of religion, this appears to be a wide and largely unstudied field. Sulaymançi, Nurçu and Fetullahi belong to this category, and I argue that the phenomenon of Milli Gorüş must also be placed there. However, simply studying their websites cannot elucidate historical and methodical relationships between these groups. Students of the preacher Sulayman (Sulaymançi), Said Nursi (Nurçu) or Kotku (Milli Gorüş) as a rule do not sell the Sufic 'product'. Because of this, important historical clues such as genealogies, hagiographies or sequences of awrad prayers are missing from their web presentation.

Sufic web offerings mainly consist of texts devoted to the history of the Order, devotion, prayer instructions and examination of 'the heart'. Different from these, Milli Gorüş, Sulaymançi and Nurçu sites are guided by one and the same Qur'an quotation: 'The best of men is he who is useful to mankind'. Under this heading, all sorts of items are brought together that touch upon the advancement of Muslims under circumstances of migration. Erecting prayer halls, securing halal meat, organizing the Kursiv hajj and other religious festivals, offering courses in Islamic jurisdiction and theology all of these activities form part of the task these organizations have set themselves. Within this spectrum, Sulaymançi emphasize the introduction of an Islamic vocabulary into the German language, whereas Nurçu concentrate on the advancement of the printed Islamic press. Milli Gorüş is also responsible for language and computer courses, sports organizations, youth and women's organizations, coaching and mediation - in short, everything which touches upon the progression of Muslim daily life. But on the subject of devotion all three organizations remain remarkably silent. ${ }^{11}$

The number of Muslims that are involved in Sufi devotion in Germany is open to conjecture. In 1991, Ludwig Schlessmann estimated their numbers to be approximately 1000 members, whereas Karl Keller counts 10,000 for the whole of Western Europe. ${ }^{12}$ But Abdullah Halis Dornbrach claims that between ten and fifteen per cent of Turkish Muslims in Germany and twenty per cent of German Muslims belong to one Sufi community or another, raising their number above 200,000. My own research in Berlin during 1997 and 1998 on Muslim religious life confirms this claim. ${ }^{13}$ Among the seventy Sunni and Shi'i prayer halls in this city, our research team noted one Rifa'i, two Qadiri, one Burhani and two Naqshbandi-Khalidi khaniqat. ${ }^{14}$ These consist of relatively small Order houses, and together they add up to no more than 800 members. However, next to these, the nine Sulaymançi mosques also organize halqas and dhikr gatherings, sometimes as often as four times a week. And in ten of the Milli Gorüş mosques, collective dhikr gatherings take place every Saturday night, with both men and women joining in. What is more, female hoças frequently organize women-only halqas and offer courses on Sufic knowledge. 


\section{The evolution of the Naqshbandi-Mujaddidi}

All in all, twenty-seven Berlin tekkes, madrasas and prayer halls - more than a third of organized religious life - in some way or another appeared to be regularly involved in forms of Sufic devotion. We also frequently heard stories about prayer circles connected to therapy sessions that were organized in private quarters, but it was not possible to include these in our estimations. It remains difficult to give a concrete estimate of the number of participants. However, the fifteen per cent Shaykh Dornbrach suggested in 1991 seem to be a rather safe guess. Since many migrants who settled in Berlin came from Anatolia, the heartland of Turkish Sufism, migration to this city has been somewhat different than to other German urban centres. Nevertheless, Berlin may be taken as an example for devotional patterns in Muslim community life all over Germany. Seventy-five per cent of German Islam has originated from Turkey, with Milli Gorüş and Sulaymançi now presenting the biggest Islamic organizations in this country. Less visible than these, Naqshbandi and Qadiri have a strong presence, but so do the Chishti-Qadiri and Qadiri-Rifa' $i$ with genealogies that include many Turkish saints. What is more, thirty per cent of Turkish migrants are of Alevi descent, and among these Bektashi and other, much looser forms of Sufic devotion prevail.

\section{The Sulaymanç da'wa-organization}

Five recent dates mark important events in the history of the students of the preacher Sulayman Hilmi Tunahan: 1959, 1973, 1979, 1994 and 2000.

In 1959, the preacher himself died in Istanbul, leaving behind about 100 students. These were rural peasants with hardly any education, whom he had taught to read and recite the Qur'an in order to perform religious services in their villages. Sulayman was a shaykh of the Naqshbandi-Mujaddidi, but because of Turkey's forced modernization during which the orders were abolished, he refused to continue his branch or to appoint a khalifa. It so happened that he became the last of a spiritual chain (silsila) that had descended from the Indian Shaykh Ahmad Sirhindi in the seventeenth century, via Shaykh Ghulam 'Ali and Shaykh Ahmad Sa'id Faruqi to a largely unknown Mujaddidi branch in Medina at the end of the nineteenth century. From there the chain was transferred to Istanbul in the 1920s (Map 3.1). But by the time Sulayman died, all traditional Sufi orders were persecuted, and knowledge of the Islamic sciences was in danger of disappearing. As a reaction, he told his students to discontinue the order branch, but to nevertheless hold on to its central ideas. And this they did. After his death, his son-in-law Kemal Kaçar proceeded to organize the preachers' work in a more systematic way and created a world-wide administration. Because Sulayman had forbidden him to take his place as 'gate' to the chain, Kemal Kaçar oriented the community of followers toward the letters of Ahmad Sirhindi as a source for spiritual guidance instead. These changes resulted in the present missionary organization I propose to call a Sufic lay community.

In 1973, migration to Europe and especially to Germany was already well under way. In the previous years, Sulayman's followers had managed to establish 150 prayer halls in Germany, each of them with a centre for the study of Qur'an and the Islamic sciences attached. In 1973, these were united under the label of 'The Islamic Cultural Centres' (ICC), with their central office in Cologne. The ICC is an organization for 
The Genealogy of the Naqshbandi-Mudjadiddi: from Dehli to Medina to Istanbul to Germany

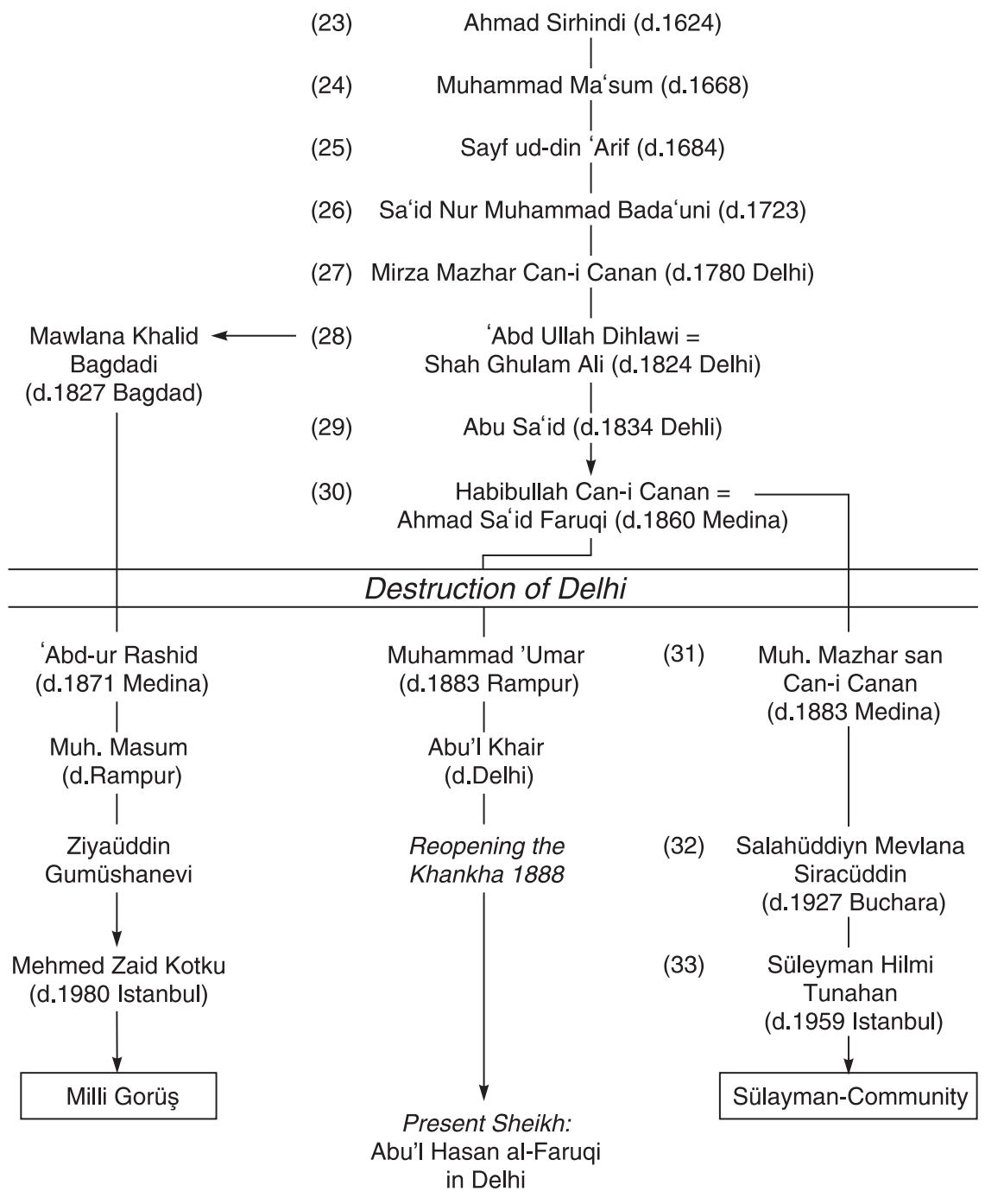

Map 3.1 Relationship between Naqshbandi-Khalidi and the Islamic organization Milli Gorüş.

the furthering of the Islamic sciences. The internal structures centre on local prayer circles (balqas), which constitute the smallest social units of the organization. These halqas function simultaneously as places of meditation, as study and solidarity groups, and its members also regularly perform missionary duties together.

In 1979, the ICC went to court to demand the right to be acknowledged as a religious community comparable to the majority churches in Germany. Secular Turks and representatives of the Turkish State in Germany vigorously objected to this plan 


\section{The evolution of the Naqshbandi-Mujaddidi}

and produced stories to incriminate the ICC. As a result, German trade unions, churches and the government became suspicious of the aims of the ICC. The ICC's devotional life, both the imitatio Muhammadi and the performance of the silent dbikr, was interpreted as a sign of secrecy that covered up unlawful activity against the German State. Due to the incriminating stories and the general appearance of ICC members themselves, the ruling judge rejected their demands. ${ }^{15}$ In the years that followed, the organization retired from public life, stopped communicating with the outside world and concentrated on the establishing of additional centres instead. Their number rose to 300 .

However, in 1994 the new head of the European organization decided upon a different course. He argued that for the new generations, the aim of achieving acceptance in German society should take equal place with the da'wa aim of spreading the faith. This director also encouraged young people born in Germany to occupy prominent posts within his organization. Contacts to churches were (re-)established locally, and dialogue circles sprang up in many locations. The ICC also established the first Islamic Academy in Germany, which was soon considered to be its main window to the non-Muslim world. These activities were labelled as 'normalization' and officially declared part of the da'wa assignment.

Finally, Kemal Kaçar died in Istanbul in the year 2000, and Sulayman's grandson took his place as leader of the world-wide da'wa organization. As soon as he took office, the new leader terminated the course on which the European ICC had embarked. The aim of the organization, he declared, was now to be the rescuing of the souls of Turkish children. Communication with European society cannot further this. The young generation, which had recently entered the European management, he expelled from their positions. Instead of entering a dialogue with society at large, a newly appointed (and much older) management has now been urged to establish boarding schools all over Europe, with an emphasis on Germany. ${ }^{16}$

Today, the ICC has 350 centres all over Western Europe, as well as some branches in the USA and in Australia. The majority of them (299 centres) are concentrated in Germany. The German organization has 20,000 registered members, but as a rule each member represents an entire family, which raises the number of people active in the organization to approximately 60,000-80,000. Members call themselves $\ddot{u} y e$, as distinct from the cemaat, the general Muslim public that makes use of the da'wa facilities. But not every iiye is also member of a prayer circle. Those who participate in a balqa are called ibwan or 'personnel'. Once admitted, they take an oath to perform the dhikr prayers for the rest of their lives, as well as to become active for the organization. Another name for them is tevziat fuzuat, 'civil servants'. With this term, the preacher Sulayman once described the assignment given to his peasant students. Upon sending them home to their villages, he ordered them to be a 'civil servant in the service of Muhammad', as distinct from the civil servants the Turkish state had employed in 1954 to administer the religious duties of the Turkish people. The term is still held in high esteem. It encourages its bearers in their conviction to have a special - divine - mission in life. ${ }^{17}$

To fulfil this mission - the rescuing of Islamic faith through the spreading of the Qur'an and the Islamic sciences - the ICC developed a dual organization, consisting of a spiritual and an economic sector. The spiritual sector includes a vocational training, 
organized separately for men and women. After three years and a series of difficult examinations during which they must give proof of their knowledge of the Islamic sciences, students receive the ijaza and become a teacher, or boça. They are then sent back to their places of birth, mostly German cities. Back home, volunteers assist them to educate the children in the reading and reciting of the Qur'an, and also to recruit new students for vocational training. As a rule, these teachers teach Turkish children whose parents are affiliated with different mosques, but especially with Milli Gorüş and state mosques. Recruitment usually takes place through the children, as these bring along their younger brothers and sisters and often enough convince their parents to become members. Whenever physical expansion becomes necessary and the community considers the opening of a new location, the economic sector jumps in to assist. Whereas the actual financing must be accomplished by the local ïye, the economists and lawyers employed in this sector offer support through a series of infrastructures. These may reach from building provisions and central bank negotiations to security services and packaged telephone contracts. ${ }^{18}$

Although the ICC is constructed as a hierarchy and headed by a charismatic leader, the organization bears some modern characteristics. To facilitate its mission, it has accepted a certain degree of internal differentiation and professionalization. The lawyers, economists and architects that the organization employs carry full responsibility within their own fields of expertise. During the recent period of opening up toward the wider society, new experts have appeared, both in interreligious dialogue and in cultural work. But it is local spiritual leaders who supervise the hoças, in their turn controlled by the European directorate. The Istanbul leader has the final authority. Although the institution of shaykh was abolished in this organization, this leader nevertheless is trusted to have not only the necessary organizational know-how but also maneviat, or 'spirituality'. Already the old leader Kaçar was said to have received it from the preacher Sulayman in person. But Sulayman's grandson, who recently took over his position, is thought to be imbued with maneviat from two sides: through the blessing of Kaçar on his deathbed and through blood ties. The possession of maneviat is indispensable for the success of the organization, the members claim. It makes children learn and renders parents enthusiastic; it helps the ibwan to stay loyal to their cause and the ïye - even cemaat - to spend lavishly. Its possession does not give the leader the power of a shaykh - he can never be the 'gate' to the silsila - but it certainly turns him into a very special person. ${ }^{19}$

Viewed from outside, there seems to be a bias in the Sulayman organization. As said before, it claims not to be an order and its leader not to be a shaykh. Yet, the organization preserves the main feature of a Sufic Order - the reception of divine inspiration through the 'help' of spiritual forbears and the presence of a spiritual leader serving as 'gate'. Whoever in this organization participates in the dhikr focuses his or her concentration on a photograph of the founder. In death, he remained the communities' 'gate' and no living person is allowed to act as an intermediary instead. As might be expected, his grave in Istanbul acts as the organization's anchor. Members visit it whenever they can. Because of suspiciousness on the part of the Turkish government, they are instructed to approach the spot in small numbers, recite a small Quranic prayer, stay for ten minutes at the most and generally act as inoffensively as possible. Notwithstanding these restrictions, many claimed to have been able to experience Sulayman's presence, 
receiving inner peace and intense moments of insight. A photograph of this grave is the most exhibited picture within the community.

All this puts the present leader in a rather biased position. In a way, the community expects him to act as a charismatic person and hand out grace, yet he cannot become a shaykh. The strain was felt very clearly when in 2000 Kemal Kaçar died and Sulayman's grandson, Ahmad Arif Denizolgun, took his place. The successor was presented as an able administrator and indeed the changes he proposed were all of an administrative nature. Yet a ripple of speculation went through the German local communities. People discussed questions like: Does Ahmad Arif have maneviat? Are his decisions really inspired? There were also stories of dreams and 'unnatural' happenings in connection with the new leader. It was clear that the believers wanted him to be something more than a university-trained professional. In order to become accepted, his decisions simply needed additional proof of divine guidance.

\section{Sufic lay communities}

Alan Godlas, who has provided us with an English-language web directory on Sufism, distinguishes in his entry 'Sufism and the West' between Islamic, quasiIslamic and non-Islamic Sufi orders/organizations. Whereas under the first heading, eight different traditional orders can be traced in the USA, the latter do not necessarily practice Islam (four addresses in the USA) or have disconnected their teachings from this religion altogether (six addresses in the USA). ${ }^{20}$ Turkish Muslim organizations, which combine Sufic devotion with missionary zeal and modern forms of organization, do not seem to fit into any of these categories.

Several points justify the introduction of 'lay community' as a new category in Sufic self-organization. ${ }^{21}$ Firstly, contrary to mainstream Islam, Sufic Islam knows different types of religious experts. After the prohibition of the orders in Turkey, this type of religious expertise was substituted by a state-controlled theological training that generated professionals in state office. As a consequence, Turkish Islam today is still based on experts, both in its traditional and in its modern, secular form. Turkish Sufic lay communities have distanced themselves from shaykhs and state theologians alike. Instead, they have started to produce their own personnel (ibwan), while converting the former function of the shaykh into a missionary vocation. Through its educational system, the ICC produces learned members who have a particular function in the missionary machine. Officially, no charismatic authority exists who can guarantee the attainment of grace. Theologians in state office are not accepted either. Both functions have been taken over by the prayer circle. Its members have equal status, insofar as their engagement pivots around the common cause.

Secondly, the phenomenon of lay communities belongs to modernity. ${ }^{22}$ It is based on the modern idea of society being an object that can be renewed. Most Christian lay communities also emerged as a spontaneous protest against religious laxity, political oppression or both. ${ }^{23}$ What both Christian and Muslim organizations have in common is their being organized around a specific religious cause. For Christian lay communities, this cause was often shaped by welfare or missionary goals. For Sufic lay communities, both in their country of origin and in the West, the religious 
agenda is defined as the spreading of the divine message. This is accomplished through explicit religious conduct, through the organization of religious education and the printing of religious books, as well as through forms of political organization. Members of Sufic lay communities are, as a rule, engaged believers, willing to dedicate a substantial part or even all of their lives to the cause. This cause is formulated as a worldly pursuit.

Thirdly, although still an important element of religious life, the pursuit of the spiritual is no longer central. In lay communities, spirituality, the reception of divine grace and the ensuing liberation of the soul are considered instrumental to the main organizing principle, which is the renewal of society in general and of 'normal' believers in particular. The engagement of all members in a closely knit community has replaced the hierarchical approach to spirituality. It allows for a learning model instead, in which the members teach one another, the more experienced taking the lead. The cohesion of the community has replaced the certainty of the hierarchical model, but without losing sight of the goal of attaining divine grace.

Lastly, the transfer from a spiritual to a worldly cause and from a hierarchical to a learning structure has also produced new uncertainties. Many Christian lay communities that were once built upon religious conduct eventually lost sight of their religious core and turned into secular organizations. Muslim lay communities are aware of this danger, and this realization sometimes serves to justify dramatic changes in organizational or missionary strategies. The recent history of the Islamic Cultural Centres in Germany outlined above illustrates how such changes may come about.

Sulaymançi today vehemently disclaim their Order descent. But authors with intimate knowledge of Sufism nevertheless recognize them as part of the family. Abdullah Halys Dornbrach, quoted above, saw the agreement, as did Abdülkadir Gölpinarli, member of the Turkish Kalendiri Order, who kept track of Sufi orders after their abolishment in Turkey. ${ }^{24}$ More research is needed to find out in what ways other lay communities, such as Nurçu, Milli Gorüş or the students of Fethullah Hoca have transformed the religious heritage of their founders into something new. The life and times of the preacher Said Nursi have been documented exhaustively by Sherif Mardin. It is a pity though that his in-depth research never touches upon matters of devotion. ${ }^{25}$ Likewise, studies of the Milli Gorüş organization do not go into the issue of its religious origin and present modes of religious communication. ${ }^{26}$ The organization is a Naqshbandi initiative for the creation of Muslim community life under circumstances of migration. In the course of my present research, I have noticed that many people in Berlin who attend one of the ten Milli Gorüş prayer halls also participate in loose gatherings in which the loud $d b i k r$ is being performed. These are treated both as leisure time arrangements and as events to find some form of psychological relief. In addition, I regularly come upon murids of different Naqshbandi branches who work independently in the Milli Gorüş mosques (Map 3.2). It becomes quite clear that the organizational frame, which this lay community has developed, differs from that of the Sulaymançi. Assessing the difference brings to mind Max Weber's warning that the internal organization of a religious community cannot but express the specificity of its religious incentive. However, tracing the consequences of this insight would go beyond the scope of this contribution. 
Relationships between Naqshbandi-Khalidiye and the Islamic Organisation Milli Görüș

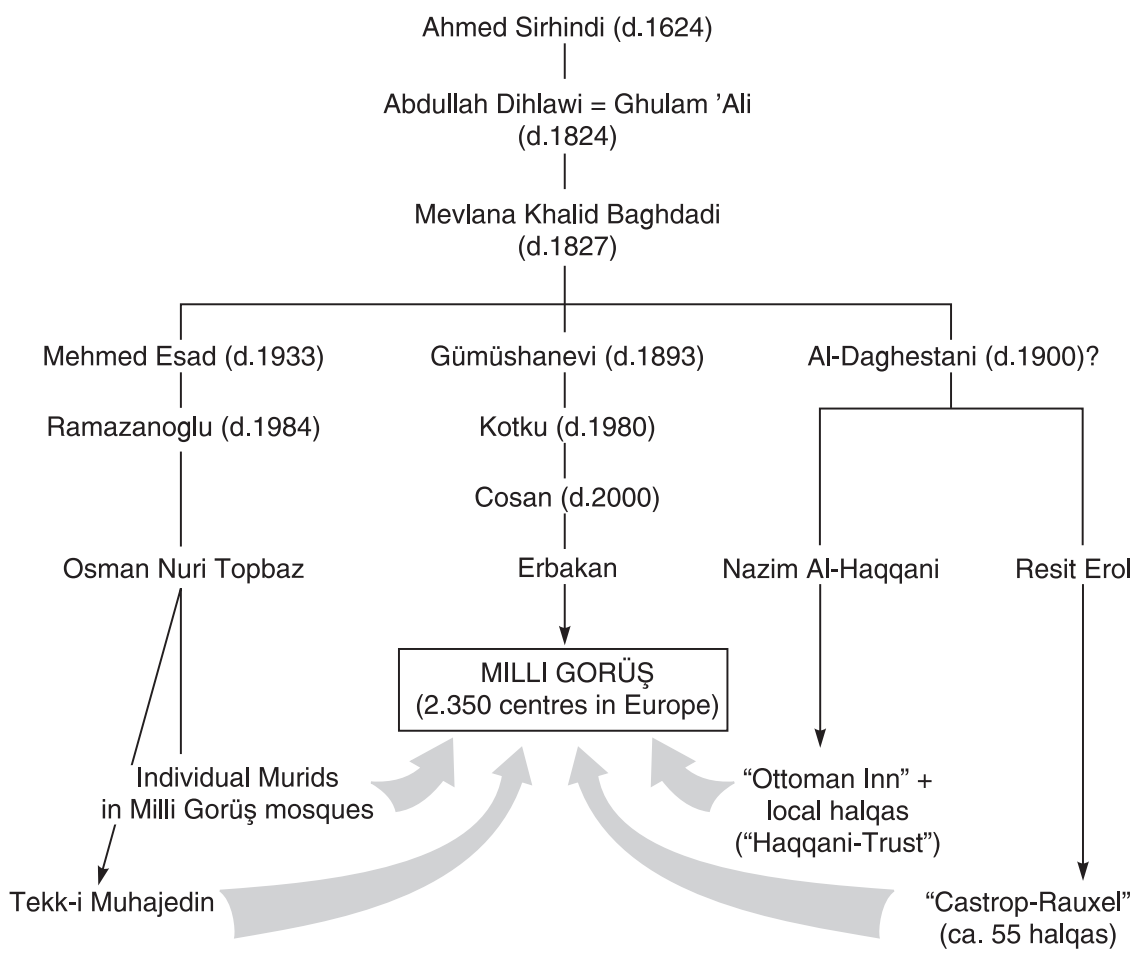

Map 3.2 The genealogy of the Naqshbandi-Mujaddidi: from Delhi to Medina to Istanbul to Germany.

\section{Imitating Muhammad}

Male students of the Sulayman heritage, whether twenty or seventy years old, whether situated in Amsterdam, Vienna, Istanbul or Boston, resemble each other in appearance and conduct. They formally dress in a grey flannel or dark blue suit, preferably with a vest, underlain with a white, striped shirt and striped tie, topped off with elegant cuff links and a tie pin. Their hair is cut short behind the ears, and faces are clean-shaven. Some have a small moustache, but I never saw a beard. Their speech is also formal, polite and unobtrusive, and the way they move might be called ceremonial. Whenever these men are not in direct communication with someone, their gaze is turned to the floor and their faces take on a curiously inward-looking expression. To the interested observer, they appear to be in meditative control of their movements, their speech, their emotions and even their breathing. But to less interested dialogue partners such as journalists, politicians and judges their manner seems to radiate an air of secrecy and elitist consciousness, which in the past has provoked imputations such as 'camouflage', 'militancy' and 'occult doctrine'. ${ }^{27}$ 
In an early stage of our acquaintance, the leader of the Berlin ICC community explained to me that they - the students of Sulayman - were followers of the Prophet through their personal conduct. As most practising believers imitate the conduct of the Prophet, this was not exactly a new insight. However, it became quickly clear that Sulaymançi follow a method of imitation different from that of most other Muslim practitioners. To illustrate their approach, my interviewee quoted some of the kalimat qudsiye to me, the Order rules as laid down by Naqshband in the fourteenth century. Among these, he stressed 'awareness of the feet', 'awareness of the breath' and 'solitude in company' as particularly important principles. ${ }^{28}$

This seemed an interesting explanation in more than one respect. The kalimat qudsiye contain eleven rules, which for the main part are concerned with reconstructing the memory of the primordial bond between God and man. ${ }^{29}$ Of these, the ones quoted to me only seemed to concentrate on the first 'bodily check-up', so to speak. The explanation also transferred rules that in some other time and place had aimed at self-annihilation and unio mystica to the firmer ground of personal conduct. My interview partners confirmed this guess. Students of Sulayman, they stressed time and again, take a much more sober approach than mystics of bygone ages:

In earlier times, there were tekkes everywhere. One could hear suhbats in many places and shaykh and murid stayed together for a long time. We don't do that anymore. Now, [religious] education is performed collectively. Thanks to a sober view of Sufism, we now possess a modern organization with a spiritual connection. ${ }^{30}$

Instead of seeking mystical experiences, Sulaymançi work on their personal conduct: 'We try to refine whatever we undertake. We polish it and make it as beautiful as possible. ${ }^{31}$

It took some time before I realized that this was a quotation from Wali Allah, an eighteenth century Naqshbandi-Mujaddidi shaykh in Delhi (Map 3.1). ${ }^{32}$ Thus I knew I had stumbled upon a reinterpretation of the old Tariqa Mubammadiyya. The Tariqa Mubammadiyya is a school of thought that once flourished in India, proposing the imitation of the Prophet as a way to reach mystical union. The attainment of this goal was intimately connected to the exact application of the shari' $a$ in one's own life. ${ }^{33}$ During the eighteenth and nineteenth century, shaykhs from the NaqshbandiMujaddidi genealogy were much given to making delicate observations on the Prophet's life, taking into view 'all he had said, done and silently approved of'. Because the method stresses the 'polishing' of even the smallest details of one's own personal conduct, students came to think of themselves as direct representatives of the Prophet. For some, the refinement of personal conduct also built a defence against the wave of political awareness resulting from colonialism, a wave that had taken most of Muslim India in its stride. In particular, the saints of the spiritual chain Sulayman represented preferred to trace and apply new details rather than to take notice of the profound societal changes around them. ${ }^{34}$

A hundred years later, and thousands of miles removed from these happenings, the preacher Sulayman encouraged his students in Istanbul to become 'civil servants' in the service of Muhammad. Against the backdrop of forced modernization and the control 


\section{The evolution of the Naqshbandi-Mujaddidi}

the Turkish Republic exercised over religion, this statement directly challenged the state. Against the civil servants commissioned to organize religious life from 1954 onward, Sulayman had dared to set a different type of 'civil servant', this time commissioned by no-one less than the Prophet himself. In this political setting, the stressing of a personal conduct, guided by shari $a$, was not meant to produce withdrawal from worldly affairs. On the contrary, the preacher and his students, through the 'polishing' of the details of the Prophet's life in their own conduct, intended to give an answer to what they considered to be a catastrophic political development. In other words, the idea of a 'modern organization with a spiritual connection' that emerged in this context was first of all a reaction to Turkish secularization. Its institutionalization into a lay community with a da'wa mission, however, took place some time later and in a different setting. The European framework in which this was accomplished presented a fundamentally different set of institutional expectations. As a result, more re-imaginings of the tradition were needed to fit this new context. The way young women in the ICC interpret their mission today may serve as an illustration.

Female students of the Sulayman heritage realize the imitatio Mubammadi in ways that mirror the conduct described above, but sometimes surpass that of their male counterparts. Like the men, they dress and speak modestly and unobtrusively. Twenty years ago, they still appeared in public without covering their head, so as not to attract attention in a non-Muslim environment. Today they simply knot a scarf under their chin, refusing to go with the Islamic fashion and accentuate the hair underneath. Like the men, they turn their gaze to the floor and use every spare moment for prayer. What is more, these women constantly make subbat amongst themselves, which is something the men are not doing habitually. This means that whenever they have a moment of time together, while waiting in line or for classes to begin, these women choose a verse from the Qur'an and apply its content to their own situation:

Of course we could speak of different things, tell each other all sorts of things, but no, we do it as the Prophet once did. Our Prophet passed on his knowledge like this, his friends memorized it and recounted it to others and so on, and now I hear it and memorize it and also recount it to others. That is a good feeling. We are the People of the Way (abl-i sunnet). We always want to act just as the Prophet did. We want to know exactly the same things he knew. ${ }^{35}$

With the help of this method these women investigate their space, its potentiality and its perimeter. Their collective interpretation of an ayat is their legitimate instrument to define their role in the religious community and beyond. In addition to being a 'civil servant', this serves as a means to free them from being treated as a symbol. Instead, women are active participants in religious communication:

For instance, the other day somebody quoted 'Obey whom is set above thee'. Making kiyas with that one immediately made clear that Kemal Kaçar is set above us all. So, we obey him. Nurettin Abi is responsible for Europe. He is our boss and we do what he tells us. But I am the leader of the [female $]$ training. What I decide in here, others have to respect. That's why we meet in the 
women's congregation every other week. And what we do not discuss in there is discussed over the telephone later. That is why the telephone rings constantly. This is my territory! ${ }^{36}$

In the Introduction of Tradition (1981), Edward Shils describes traditions as guiding patterns for the re-enactment of the past. Whether past and present are really identical to an external observer is not a relevant criterion, he says. Important is whether those partaking in the tradition recognize its essence and perceive its continuity with the past. ${ }^{37}$ In the wide berth of the Islamic tradition of following the Prophet, many details offer themselves for re-enactment. But what choice is actually made is dictated by the needs of the present.

What these men and women are looking for are strands of religious knowledge which can fortify their mission, and give them a means of doing so in the best way possible. They are not explicitly in search of a method to appease 'the heart' and climb the ladder towards mystical union. But their halqas keep the lifeline to God open, and 'inspiration' might find them when it is most unexpected. Through these halqas, it is the organization as such, not the individual, which is in possession of the 'spiritual connection'. And although the recent decisions of the new leader have been extremely hard on the young European members, this is the main reason for remaining with the organization.

\section{Conclusions}

The history of the students of the preacher Sulayman is barely forty years old. It is the history of Naqshbandi Sufic devotion that has distanced itself from its Order, producing instead learned members with a common cause. The 'modern organization with a spiritual connection' that has been created is a reaction to Turkish forced secularization. In the eyes of these Muslim practitioners, the political event was catastrophic because it did away with all spiritual values and methods to obtain grace. Migration brought this response to Europe before it was properly institutionalized, and it is the Western European framework that left its imprint on the present organizational shape. Its result I have termed the Sufic lay community.

Contemporary history seems to be far removed from the origins of the Naqshbandi Order, and indeed, the eleven holy rules that gave the Order its profile in the fourteenth century have been abandoned with the exception of three. Yet, over the centuries, the evolution of the Order has thrown the switches for this particular development. The link must be traced from Bukhara to Delhi, to Medina, to Istanbul and on to Cologne. At each geographical stage, the societal and political frame necessitated a different focus, which in turn transformed the Order. Its beacon, Shaykh Ahmad Sirhindi, already set course toward a much more 'sober' ideal in the seventeenth century. His decision that the return to reality (baqa) after having been lost in God (fana) should be the mystics' ultimate goal, was the starting point for the Tariqa Mubammadiyya. Generations of holy men after him tried to 'polish' their lives as best as they could, imitating the Prophet. After all, it was not Sulayman's fault that this religious endeavour got caught in the reticule of a political ideal striving for the modernization of Turkish society. 


\section{The evolution of the Naqshbandi-Mujaddidi}

The students of the preacher Sulayman, through their formal and modest appearance, through dedicating their free time to prayer, through the collective interpretation of Qur'an texts and - last but not least - through the continuous studying of Sirhindi's letters, tried to rescue what was left. In the course of this effort, they abandoned all external reminders of the Order history and refocused on the triad of religious knowledge ( $\mathrm{ilm}$ ), personal conduct ('amal) and utmost fervour (iblas). In doing so, Sulaymançi have created a particular set of religious communications, one which centres on the body and heavily underlines personal responsibility. Members of any traditional Naqshbandi tariqa no longer recognize this communication as belonging to their own tradition. And although students of Sulayman still consider Naqshbandi murids as close religious neighbours, for their part they judge the latter's religious communication as egocentric and quite disconcerting. ${ }^{38}$

However, what the preacher Sulayman and his students have created is not just a continuation of the past. For three generations now, Sulaymançi have decided to dedicate their lives to the spreading of the Qur'an, the preservation and continuation of the Islamic sciences and the adaptation of its religious core terms to the languages of Western Europe. Personal conduct based on imitation of the Prophet legitimates and serves this aim, but can no longer become an aim in itself. The requirements of the present, as they perceive them, dictate a different approach.

Religious systems are not primordial entities. Turning Shils' dictum around, the present appears to be the only possible starting point for reconstructions of the past, whether of a religious nature or not. Modernity was the framework from which this particular transformation took off. It resulted in a lay community prone to secularization, and this in itself is a modern phenomenon.

\section{Notes}

1 The monograph originating from this piece of fieldwork was written in German (Jonker 2002). This article means to give an overview. See also Jonker (2004).

2 Beyer (1998), p. 90.

3 Order addresses: Mevlevi.de; Muslim.de; M.T.O.Shahmagsoudi.org; Alawiyya as-Safinah. Private adresses: sufifreepage.de/sufism.htm; petama.ch; planet-intercom.de.

4 For example Der Spiegel 12/1998, pp. 86-98.

5 Dornbrach (1991) (14 pp.)

6 Schlessmann (1991); Keller (1991), pp. 359-390; Spuler-Stegemann (1998), pp. 134-146.

7 Spuler-Stegemann (1998), pp. 141-143.

8 Schlessmann (1999), pp. 12-22.

9 CIBEDO (1999), p. 113: Tariqat As-Safinah; CIBEDO (1981), pp. 3-21 (author unknown); CIBEDO 1983 pp. 3-19 (author unknown).

10 With the exception of Jörg Hüttermann (2001). This research has concentrated on the building of milieus and peer groups within the Naqshbandi-Khalidi Order centred in Castrop-Rauxel. Through long biographical interviews the author traces the societal background of young male members and their reasons for joining. His observations describe patterns of male friendship and bonding against a Sufic horizon.

11 Adresses: VIKZ.de (Sulaymançi); IGMG.de (Milli Gorüş); solzer.com.tr (Nurçu).

12 Schlessmann (1991), p. 145; Keller (1991), p. 366.

13 Jonker and Kapphan (1999). 
14 For reasons of internal coherence, Turkish Alevi forms of worship were excluded from this particular research project.

15 Jonker (2002), chap. 3.

16 Jonker (2002), chap. 4.

17 Jonker (2002), chap. 4. Interview with one of the preacher's few surviving students, at the time of interview 63 years old $(5 / 2000)$.

18 Jonker (2002), chap. 4.

19 Jonker (2002), chap. 4.

20 Arches.uga.edu/-godlas/Sufism.html, pp. 5-8.

21 The argument is unfolded in greater detail in Jonker (2004).

22 Eisenstadt (1998), pp. 43-76.

23 Eisenstadt (1998), pp. 46.

24 Gölpinarli (1969a,b).

25 Mardin (1989).

26 Excellent research on the political dimension of Milli Gorüş has been provided by Seufert (1997; 1999, pp. 295-323).

27 Jonker (2002), chap. 3.

28 Head of the Berlin administration, 44 years old at the time of interview (11/1998).

29 (1) Hush dar dam: Control of the breath; (2) Nazar bar qadam: Control of the feet; (3) Safar dar watan: Voyage to the spiritual country; (4) Khalwat dar anjuman: Solitude in company; (5) Yad kard: The act of remembering; (6) Baz gasht: The return of memory; (7) Nigah dasht: The protection of memory; (8) Yad dasht: The retaining of memory. (9) Wuquf-i qalbi: Control of the heart; (10)Wuquf-i zamani: Control of time; (11) Wuquf-i adadi: Control of numbers (cf. Ter Haar (1992), pp. 47-57+ glossary).

30 Librarian of the German ICC, 36 years old at the time of interview (7/1999).

31 Head of the Berlin Administration, op. cit.

32 Schimmel (1981), pp. 192-214.

33 Schimmel (1981), pp. 194.

34 Fusfeld (1981), pp.198-236 ('The Khanqah up to 1857').

35 Head of the female training in Cologne, at the time of interview 24 years old (4/1999).

36 Head of the female training, op.cit.

37 Shils (1981).

38 Jonker (2002), chap. 7 ('The Rite of Remembrance'). 


\title{
4 Third-wave Sufism in America and the Bawa Muhaiyaddeen Fellowship
}

\author{
Gisela Webb
}

Sufism, or tasawwuf, is the 'mystical dimension of Islam'. 'The term refers to a variety of modes of spirituality that developed in the Islamic world, including asceticsocio-critical movements, esoteric and poetic interpretations of the Qur'an, and spiritual confraternities. The goal of Sufism has consistently been deepened devotion, spiritual transformation and ultimately the interiorization of the basic tenet of Islamic belief 'that there is no God but the God', or in the classic Sufi interpretation, 'Only you, O God, are the Real (al-Haqq)'. Sufis have historically been major transmitters of Islam to regions far beyond the religion's 'Middle' Eastern origin - Central Asia, Africa, the Indian subcontinent, the Malay-Indonesian world - and Sufis have continued that tradition in North America. However, until the 1990s there was little scholarly attention given to Sufism in America. There are a number of reasons contributing to this situation. First, there was a tendency among Orientalist academics, anti-cult groups and traditional Muslims alike to lump the American-bred Sufi groups into categories such as 'cults', 'new age', popular religion, 'sects', or 'unorthodox', thereby dismissing Sufism as a serious topic in the study of religion. ${ }^{2}$ Second, the historical situation (including the historiography) of Sufism itself, both inside and outside the Islamic world, has complicated the issue of understanding the relationship of presentday Sufi movements to traditional Islamic practice. That is, Sufism has always been an alternative discourse in the Islamic world, existing side by side, at times in tension, with more 'conserving' and legalistic elements in the tradition, and there continue to be voices in Islam that would deny the legitimacy and pervasiveness of Sufism in Islamic cultures. Add to this the criticism by some modernist and fundamentalist/ultra-conservative elements in the Muslim revivalist discourse who see Sufism as tied to pre-colonial, colonial and post-colonial situations of backwardness, pacifism and societal decay. Add to this the lack of attention given in contemporary Islamic Studies to the relationship of classical traditions in Islamic mystical literature (oral and written) to their actual use in the lives of ordinary and learned Muslim individuals. Related to this is the lack of attention given to the role of the 'holy personage', the wali Allah (the 'friend of God'), which was historically the central focus of popular religious and devotional life in virtually every region of the Islamic world. ${ }^{3}$ A final complication is that there are indeed many Americans involved in Sufi movements who emphasize historical Sufism's language and goal of 'the transcendent unity of God beyond all distinctions' (including religious differences) in a way that 
denies any 'essential' connection of Sufism with the religion of Islam. ${ }^{4}$ Despite this constellation of issues affecting the discourse on Sufism, there is enough evidence to suggest that contemporary Sufi orders have been continuing their historical role as major sources of transmission of Islamic cultural and religious beliefs, values and practices to North America.

I would further argue that Bawa Muhaiyaddeen and the 'Fellowship' he founded have continued this transmission while addressing and indeed affecting, the discourse on the relationship between 'Islam' and 'Sufism' in the current 'globalized' societal order.

\section{First-wave Sufism}

One can identify three major phases of Sufi activity in America. They roughly correspond to three distinct periods of interaction between Euro-American and Asian worlds in the twentieth century. The first period, beginning in the early 1900s, is characterized by the interest of Americans and Europeans in 'Oriental wisdom', which grew out of contact that Europeans had with Asians (in the broadest sense) during the colonial period. Along with the negative aspect of 'Orient as other' that characterized the period, the interaction of cultures did produce a number of teachers trained in both traditional learning and European institutions, who saw a spiritual lack and longing in the West and who felt compelled to bring their teachings to the West. Of course there were those who were less than authentic masters; in any case, this wave of teachers from 'the East' had a receptive audience in the United States. Hazrat Inayat Khan, who in 1910 founded the Sufi Order in the West, is the most well-known representative of this period. He was trained in both classical Indian and Western music, and was initiated into the Chishtiyya order by Khawaja Abu Hashim Madani. His teachings embody elements characteristic of Chishtiyya Sufism, in particular, the melding of Indian Advaita Vedanta and Islamic wabdat al-wujud ('unity of being') philosophical perspectives, as well as the use of sacred music, to elevate and attune the soul to the unitive structures of reality at the microand macrocosmic levels. He believed he had been given the mission of spreading the 'Universal Message of the time', a teaching that could unite East and West and lead to universal brotherhood, love and peace. However, he taught that this 'Sufi' message was not essentially tied to historical Islam, that the universal truth of Sufism lay at the core of all religions, and moreover, that he was called to develop new forms of 'universal worship' for his followers (which came to involve music as well as discourses). ${ }^{5}$ His autobiographical writings provide glimpses of the attitudes and social structures underlying the early twentieth century American spiritual 'searching'. For example, he describes how in the West, 'there are no disciples, only teachers'; how prejudice and scorn pervaded attitudes toward Islam, people of colour and people from 'the East', how his audiences were of the artistic and wealthy elites. ${ }^{6}$ After initiating a number of murids (disciples) in the United States, Hazrat Khan returned to India, then returned to the USA in 1923 and 1925, establishing the first Sufi Order khangah (lodge) in Fairfax, California: the 'Kaaba Allah'. Hazrat died in 1927, leaving small groups of murids to continue propagating the 'Message', but disagreement 
among the murids regarding leadership, property and philosophies resulted in decline of the Order. The late Meher Baba attained some of the Sufi Order properties, adapted many of the Order's teachings, and created 'Sufism Reoriented'. 'Most of the 'Sufi', or Sufi-oriented, groups of the early twentieth century maintained this universalistic, theosophist orientation.

\section{Second-wave Sufism}

The second wave of Sufi activity in the United States coincided with the 1960s and 70 s counter-cultural movement in which large numbers of (mostly) young middleclass (mostly, but not only) white Americans identified the cause of racism, the Vietnam War, and the evil of technocracy in a spiritual sickness that establishment religions in America had not only failed to solve, but had fostered. It was an era of seeking teachers of traditional wisdom from the 'East' - usually 'Hindu' - with little knowledge or concern as to the historical foundations of practices such as Zen, Yoga, or Sufism. It was a time of growth in comparative religious studies departments in the United States, interest in religious mysticism (fostered by the works of Mircea Eliade, William James, Thomas Merton, Huston Smith, Seyyed Hossein Nasr, Zalman Schachter and Richard Demartino [student of D. T. Suzuki]), and crosspollination of cultures and religions. Jewish and Christian Americans studied wisdom traditions of the East and sometimes revivified the mystical traditions of their own traditions (albeit in new adaptations). ${ }^{8}$ Certainly experimentation with drugs in the name of consciousness-raising was part of the landscape. It was the era of seeing the roots of Martin Luther King's civil rights movement not only in the Bible, but in Gandhi, and Black Jewish and Black Muslim movements sought to revive elements of a lost legacy in the 'Asiatic' world. (e.g. 'Moorish Science'). The 'East' seemed to offer therapeutic approaches to individual and - perhaps as a by - product - global transformation.

Several Sufi groups flowered in this era. Some used 'Sufism' to designate a universal teaching that transcended, and need not be tied to, institutional Islamic religious doctrine and practice. These universalistic, or 'perennial'-oriented groups adopted some elements of traditional Sufi practice, but avoided overt affiliation with Islam. The most well-known example of this model was The Sufi Order of America, which was rejuvenated under the leadership of Pir Vilayat Inayat Khan, son of Hazrat Inayat Khan and his American-born wife Ora Begum. After the death of his father and upon returning to America after his European education, Pir Vilayat adjusted to his hippie audience, and continued his father's teachings while diversifying the organization and its teaching modes. Through him and other persons associated with the order, notably Shahabuddin Less and Sam Lewis, the West Coast sufi/zen/yoga/hassidic master of the late 1960s, thousands of people were introduced to 'the Message', and the Sufi Order of America became associated in popular American culture with 'Sufi Dancing' (later 'Dances of Universal Peace'). Membership increased as the order began to co-sponsor (along with other universalist groups, such as the Temple of Understanding) events such as the 'Cosmic Masses' at St. John the Divine Cathedral in New York, organized in 1975, as part of the Spiritual Summit marking the thirtieth 
anniversary of the United Nations. Also in the 1970s, the Sufi Order of the West had purchased land that had been part of a Shaker village in the Berkshire hills of upstate New York, naming it 'the Abode of the Message'. The Abode became a major host site not only for Sufi Order lectures, Universal Worship Services and Sufi Dancing but for holistic health retreats and workshops, with the Sufi Order shifting its focus or perhaps its pedagogy - to the bridging of world spiritualities, psychology, alternative medicine and ecological concerns which together characterize an important aspect of post-modern spirituality in contemporary America. Some of those inspired by Hazrat Inayat Khan's teachings have gravitated to Sufi groups that have a more traditional Islamic shaykh - disciple and communal relationship, particularly as waves of non-European immigrants have changed the religious landscape of North America to a religiously pluralistic one in which Muslims themselves will soon be the second largest religion in the United States.

The 1970s was also a period of development of branches of Sufi orders originating in the Islamic world and transplanted in the American milieu. ${ }^{9}$ The Halveti-Jerrahi Order of America is an example of those tariqas in the United States that derive from larger traditional orders of Sufism and (usually) whose living masters do not live in the United States. Spiritual guidance and authority are provided by local shaykhs. These groups hold long-established silsilas (chains of transmission of leadership) as well as traditional Islamic practices and adab reflecting their regional origins. The late Shaykh Muzaffereddin al-Jerrahi al-Halveti came to the United States from the main Jerrahi dargah in Istanbul to establish the first Jerrahi order in the West in Spring Valley, New York. He appointed Tosun Bayrak, Turkish-born but long-time resident of the United States (and well-known New York artist of the 1960s), as shaykh of the Spring Valley group, which currently consists of over 50 dervishes. The community built a mosque - Turkish and Islamic in its aesthetic - which accommodates not only the dervishes but also the growing number of 'non-Sufi' Muslims of the surrounding New York area who attend Friday prayers but not necessarily Sufi rituals, such as the regular dhikrs. Sufi mosques often become the choice of immigrant Muslims who want an atmosphere that is culturally heterogeneous, non-Wahhabi in rhetoric, conservative in morality, and traditional in practice. Normative Islamic practices reflected in community life include the affirmation of the shabada (and the other fundamental pillars of Islam) as well as courteous and proper behaviour in the shaykh - disciple relation, in gender relations and in community life. There are religious education classes for children. There is conscious appropriation of classic Sufi teaching and practice, as well as commitment to translation of traditional Sufi texts. Tosun Bayrak and member Rabia Terri Harris have translated several Sufi writings, including works by Ibn 'Arabi, al-Sulami and al-Qushairi. For the American Jerrahis, Sufism is identified with Islamic spirituality. This is not to say that 'traditional' here means a static view of Islam, for in going back to traditional Islamic sources, the Jerrahi scholars are locating precedents for reinvigorated interpretation and selfcritique (of sacred texts, of law, of traditions) within the Islamic tradition itself, using the tools of fiqh, ijtibad, tafsir (Islamic jurisprudence, interpretation, Qur'anic commentary) as living traditions for addressing new social realities. ${ }^{10}$ This new ijtibad among the educated, practising Muslims (including Sufis) is an important marker of 
a new generation of ('third wave') Sufism in the United States. Moreover, the order has become particularly active in international charitable activities in the last decade, raising money for victims of political crises and war in Iraq, Bosnia and Afghanistan. It has also become involved in educational and other social services for the economically disadvantaged in the Spring Valley area. ${ }^{11}$ Clearly, local and international engagement in peace and relief efforts in countries with Muslim populations is another characteristic that marks the 1990s and the beginnings of the third wave of American Sufism.

\section{Third-wave Sufism}

I use the term 'third wave' to designate certain types of activities that Sufi groups in America have been engaged with primarily in the last decade as they address both perennial issues that all religious communities face over time (indeed, if they are survive beyond the founding generation) and new issues related to globalization. It will be through this lens that we will look at developments in the Bawa Muhaiyaddeen Fellowship, a Sufi community in Philadelphia founded by the saintly Tamil-speaking teacher from Sri Lanka, Muhammad Raheem Bawa Muhaiyaddeen. The community had its American origins during the 'second wave' of Sufism in the 1970 s, ${ }^{12}$ but it gradually reflected a closer identification with normative Islam during the 1980s and 1990s. Despite the tensions that emerged from issues related to Sufi and/or Islamic identity, the community created an environment that would both attract and serve the current multi-ethnic Muslim diaspora community in the United States.

The perennial issues that most religious communities face include the following:

1 How the community remembers the founding story of the teacher and the community.

2 How the major teachings are transmitted during the life and after the death of the founder of the community.

3 How the self-identity of the community is defined with respect to the larger religious landscape.

4 How the community resolves issues following the death of the founder - those of continuation of leadership, governance, transmission and interpretation of the teaching, the interpreting the teachings as well as defining one's community in relationship to new 'others' (e.g. new Sufi groups in America) and new social situations (e.g. larger immigrant populations).

The reality of globalization has necessarily had an impact on the development of Sufi communities in North America in the last decade as they have responded to the following interrelated situations:

1 The patterns of migration of peoples between 'East and West' and 'North and South' and the increasing numbers of diaspora communities.

2 The increased number of immigrants coming to the United States from predominantly Muslim countries. 
3 The reality of global Islamic revivalism and heightened religious and political self-consciousness in Muslim immigrant communities.

4 The development (nationally and internationally, through meetings and over the Internet) of linkages among Sufi and non-Sufi Muslims engaged in ijtihad and social justice work, opening the door to discussions and activism related to peace, violence, gender roles and rights, poverty and racism ${ }^{13}$.

5 The proliferation of intercommunity, interfaith discussions and forums (not only interdenominational, but inter-Sufi, Sufinon - Sufi Muslim, Sufi - non-Muslim, Muslim - non-Muslim), particularly in response to 'September 11th', 'terrorism/ radicalism in Islam' and 'Middle East crisis' discourses.

\section{The Bawa Muhaiyaddeen community}

The development of the Bawa Muhaiyaddeen Fellowship is a distinct and important part of the history of Sufism in America, representing a community that has been able to unite a variety of interpretations of Sufism's relationship to Islam - 'SufiMuslim', 'Sufi-non-Muslim' and 'Muslim-non-Sufi'-under the umbrella of the 'Bawa Muhaiyaddeen Fellowship and Mosque'. With his arrival in Philadelphia from Sri Lanka in 1971, Muhammad Raheem Bawa Muhaiyaddeen became an influential exemplar and transmitter in America of the legacy of Sufi wisdom teaching that had developed in South Asia. Indeed, the content and form of his teaching, as well as his role as shaykh, present us with a contemporary example of traditional mystical theories about the nature and function of the holy personage, the wali-Allab and the Qutb. ${ }^{14}$ It is evident from the recent translation and publication (2001) of a volume of Bawa's discourses, songs and 'questions and answers' dialogues - The Resonance of Allab: Resplendent Explanations Arising from the Nur, Allah's Wisdom of Grace ${ }^{15}$ - that Bawa was bringing to his American audiences the 'wisdom teachings' he had shared with his Sri Lankan audiences. Moreover, the reception of Bawa's teachings during his years in America, as well as the appropriation and ongoing dissemination of his teachings since his death in 1986, illuminate the dynamics of transmission of Sufism in the larger context of developments in Islam in America, diaspora religion in America, and inter- and intrafaith relations in America.

\section{Sri Lanka Origins: Qutb in the Maldives}

Bawa Muhaiyaddeen's public career began in Sri Lanka in the early 1940s, when - as several of the older Sri Lankans describe - he emerged from the jungles of northern Sri Lanka, was approached by some pilgrims of local shrines who recognized him as a 'holy man', and they asked him to teach them. Several of these older members describe dreams or mystical encounters with Bawa before they met him 'physically'. ${ }^{16}$ Most of his earliest followers were Hindus from the Jaffna area, who simply called him swami, or guru. Bawa rarely spoke about his personal history and journeys, but an early publication from the 1940s, describes his travels throughout 'Serendib' before coming to Jaffna, spending several years in 'Kataragama', 'a jungle shrine' in South Sri Lanka, in 'Jailani', a shrine on a cliff dedicated to 'Abd al-Qadir al-Jilani of 


\section{Third-wave Sufism in America and the Bawa Mubaiyaddeen Fellowship}

Baghdad, and other pilgrimage sites across Sri Lanka. ${ }^{17}$ He speaks of 'toiling in every kind of work', studying all orders of creation in search of 'the Truth', or 'Primal One'. His early Jaffna audiences looked to him as a healer of medical and spiritual ailments, and as one who 'cast out demons'. To accommodate the growing number of people seeking guidance and healing from him, he founded an ashram in Jaffna. ${ }^{18}$ As whole families began to come to the ashram from distant areas of Sri Lanka, Bawa applied to the government for land to lease for farming. The farm, located south of Jaffna, was the beginning of his teaching example through both service (to the poor - by helping them clear the jungle and teaching them to cultivate the land) and teaching through the metaphors of foundational processes such as 'farming': clearing the land (the 'inner jungle'), planting the seed, nurturing it with water, clearing weeds that would choke off growth, being vigilant so that the roots can grow deep (the 'taproot') to the source of water (divine truth) below, attaining the fruit - all of which became symbols he used for the spiritual life and processes of growth therein. Several Muslims from the area of Columbo encountered Bawa's teachings on their business travels to the Jaffna area. They too accepted Bawa as a 'divinely inspired person' and began inviting him to Columbo to teach. Thus began a wider circle of teaching and travelling between the ashram in Jaffna, homes of patrons in Columbo and the farm which was located between the two cities. In 1955, Bawa laid the foundation for a mosque, or 'house of God' in Mankumban, north of Jaffna (which he attributed to a spiritual experience with Mary, Jesus' mother). The building itself would not be built by Sri Lankans, but by American followers whom Bawa would bring to Sri Lanka in the 1970s. In 1967 the 'Serendib Sufi Study Circle' was inaugurated, which became a place of study and publication of Bawa's teachings in Columbo. ${ }^{19}$ Bawa's use of fables about the jungle - its inhabitants and their characteristics - are reminiscent of Rumi's use of animal, plant and mineral life as way to analyse human nature and the elemental forces that rule within us. Bawa's teaching stories utilized imagery from Hindu sources (e.g. Puranas, Upanishads) as well as Islamic sources, including the hadith and hadith qudsi, the Qisas al-Anbiya ('Tales of the Prophets') and delightful traditional teaching stories of such figures as Muhammad, Fatimah, Gabriel, Ali, Rabia al-Adawi, Hasan al-Basri, Uways al-Qarani (clearly used by Bawa to identify his own spiritual lineage as not silsila-bound), Moses, Khidr (used to show the limits of knowledge of exoteric religion and law), Abraham, Jesus, Mary and 'Abd al-Qadir al-Jilani (with whose spiritual station as Qutb Bawa identified). It is interesting to note that both the followers of Bawa who came from a Hindu background in Sri Lanka, and the early followers of Bawa in America who tended to be more familiar with Hindu and yoga imagery than Islamic, say that in looking back, they did not know or see the preponderance of Islamic/Sufi images that they now see as there 'from the beginning'.

\section{American origins}

Between 1969 and 1971, Bawa would receive letters from a young woman 'seeker' from Philadelphia, who - like many young Americans - had been disenchanted by the wave of gurus who came through America in the 1960s. She learned about Bawa 
Muhaiyaddeen from an anthropology student from Sri Lanka studying at the University of Pennsylvania. On the basis of 'an inner experience' she began correspondence with Bawa, urging him to come to the United States. Her letters were followed by letters from others in the small group of Philadelphians that would eventually sponsor Bawa's journey. The early group of American followers of Bawa included both white and black Americans - of Christian and Jewish, mostly middle class backgrounds - now in the 'spiritual seeker'/yoga circuit in Philadelphia. African Americans in particular had hopes in Bawa as someone who - as a person of colour and colour blindness - could help in healing racial division in America. Bawa agreed to travel to the United States and arrived in Philadelphia on October 11, 1971. His American teaching began in small discussion groups at a home in West Philadelphia. Growing numbers of followers and visitors eventually necessitated different accommodations, and the burgeoning group, which began to include some wealthy patrons, purchased a former synagogue in the Overbrook area that would become - and still is - the central location of the Bawa Muhaiyaddeen Fellowship. Most of the early members say they did not come to, nor see, Bawa as a teacher of Islamic religion, or even as a 'Sufi'. He was identified more as a guru in the early years, a 'counsellorteacher' with no formal spiritual practices, someone who manifested 'pure love' and 'got us cleaned up and off drugs'. He was an ascetic, 'available twenty-four hours a day', who 'spoke of remembering God at all times', 'sometimes recommending saying La ilaba illa Allabu as a tool, but not as a mantra or yoga'. ${ }^{20}$ Bawa emphasized 'islam' as a state of unity and trust in God, an inculcation of the qualities of God, a discarding of 'distinctions' of race, caste and religion. Despite the lack of background (or intention) on the part of the Americans to recognize traditional Sufi themes and imagery, these themes are clearly part of even the early discourses of the 1970s. Among the themes are:

1 The mystical doctrine of the origin of creation (and ongoing transmission of knowledge of God) through the 'resonance' of Allah, the original 'self-disclosure' of Allah - the resplendent light of wisdom - the Nur Mubammadi, which is understood through the Qutb (or Qutbiyyah), the 'explainer', or locus of Divine Wisdom in the inner heart (qalb) of the human being. ${ }^{21}$

2 The corresponding doctrine of the Inner Qur'an, the essence of Allah's revelation(s) to humankind, and hence the inner reality of every historical revelation and religion (in Tamil, Thiru Marai, or Thiru Qur'an). ${ }^{22}$

3 Letter symbolism, including that of the Alif, Lam, Mim, corresponding to the ongoing process of self-disclosure of Allab-Nur-Mubammad, or AllabMubammad-Mubaiyaddeen. ${ }^{23}$

4 The affirmation of the yaum al-mithaq (the 'day of the covenant'). ${ }^{24}$ The Sufi understanding of which is that human beings are born in a primordial state of unity with God which is 'islam' but in our forgetfulness of that original unity, we are ruled by the lower forces within and without, and we become attached/in submission to 'other than God'.

5 Emphasis on the journey of return to 'islam' through 'remembrance' (dhikr) of God, not only through 'outer prayer and religion', but ultimately by analysing 


\section{Third-wave Sufism in America and the Bawa Mubaiyaddeen Fellowship}

who we are, what separates us from God, learning that 'only God can know God; only God can pray to God'. ${ }^{25}$

6 The role of the 'true shaykb' to help one in the process of self-understanding, in cutting away the impurities to reveal the reality (al-Haqq) within, ${ }^{26}$ and in guidance through the steps and stages of the journey and mystical-theoretical discourses, such as the 'four steps to pure iman' ${ }^{27}$ ).

7 Acknowledgement of the spiritual gifts and presence of the saints, qutbs and revivers of the faith. Bawa uses the term qutb to signify the state or faculty of qutb or qutbiyyat - the eternal capacity in the human heart of God's own power/grace/illumination - the presence of which existed in the walis and qutbs of the past, including 'Abd al-Qadir al-Jilani, the twelfth-century Baghdadi preacher who was called mubyi al-din ('reviver of the faith'), and in the historical and inner reality of Bawa Muhaiyaddeen in the present era. ${ }^{28}$

\section{Toward 'Iman-Islam': the mosque as crisis and bridge}

Between 1971 and 1986 there emerged a stronger identification of the Bawa Muhaiyaddeen Fellowship with traditional Sufism and with traditional Islamic spirituality. This identification came not only when Bawa taught the salat, the five times prayer to the members - with attention to their inner mystical meaning and their outer formal requirements, not only when he taught a silent $d b i k r$ qalbi and an aloud dhikr jali, ${ }^{29}$ but most profoundly when he announced plans that it was 'time to build a mosque'. That mosque, which would be built by Fellowship members and completed in 1984, would be open to persons of any religion for private prayer except during the times of the Muslim liturgical prayers (as had been the case in the "house of God' in Mankumban). Moreover, liturgical prayers would be conducted in strict accordance with Hanafi practice, 'such that a Muslim from any part of the world could worship here'. ${ }^{30}$

The building of the mosque was a public articulation of orthodox Islam that brought into high relief the question of the relationship of Bawa's teachings, indeed Sufism itself, with exoteric, 'orthodox' Islamic practice. Did Bawa intend a gradual movement toward Islamic religious practices (such as salat) as an outer manifestation of inner maturity and discipline, or did he intend it as a 'concession' to the human need for unifying cultural forms and rituals, despite the 'illusory' quality of religious distinction, or was it both? With the building of the mosque, several members left the Fellowship because of the overt identification with Islam that they did not want. Conservative and Islamist Muslims would attempt to challenge or distance themselves from the Bawa Fellowship because of its expression of Islam that they did not accept. ${ }^{31}$ Nevertheless, it appears that the building of the mosque has - over the years - effected a kind of legitimacy and acceptance of the Bawa Muhaiyaddeen Fellowship on the part of the larger religious community in Philadelphia and beyond - nationally and internationally, Muslim and non-Muslim. The Fellowship mosque is where most of the numerical growth in the Fellowship has taken place over the last decade. The mosque has become a symbol of Islamic (and, by extension, cultural) identity for many diaspora communities in America. There has been an increase in the number of 
individuals and families of Turkish, Indian-Pakistani, 'Middle Eastern' origin; they in turn have transmitted something of Bawa's orientation and teachings abroad. (Indeed articles on Bawa's teachings have appeared in Turkish religious journals, and there is an interchange of discussions and formal visits among Sufi-oriented Muslims in Turkey and members of the Philadelphia fellowship. ${ }^{32}$ ) Many of the Muslim diaspora community in America do not see themselves as students of Bawa, but nevertheless participate in mosque activities, especially the traditional Muslim celebrations, such as Ramadan and the Eids. The mosque also draws membership from the growing African American Muslim community, which of course sees itself as the original Muslim diaspora community in America (through the slave trade and the submersion of Islam under slavery). Finally, the mosque became the focal point where many individuals of Bawa's early community - from backgrounds as diverse as Catholic, Protestant, Jewish and Hindu - came to see their journey with their shaykh as widening to include 'orthodox' Islamic practice.

Over the years there has been a gradual accommodation of the variety of perspectives on the meaning and function of the mosque, with members agreeing that Bawa would have been able to embrace the diversity, pointing to his past inclusive Sri Lankan ministry as well as to his many statements that people may - and will - come 'here' to get what they need. ${ }^{33}$ It is clear that there have emerged three major orientations in the Fellowship: those who come for Bawa's wisdom teachings on the interior, universalist-core experience of Islam alone (focusing on acquiring 'islam' as a state of purity and unity that transcends religious forms, or 'Only you, O God, are the Real'), those who come for the mosque and 'non-Sufi' Islamic religious practices and celebrations, and those who come for both the mystical teachings of Islam and the exoteric practices of normative Islam, the latter of which are seen as an exteriorization of the inner experience and an important means of fostering community life and continuity. Moreover, the symbolic move toward a more traditional Islam through the mosque has contributed significantly to the inclusion of the Fellowship in inter-Islamic and inter-Sufi communication and solidarity, as well as civic interfaith communication and dialogue.

\section{Developments in community life: the farm and the mazar}

As in Sri Lanka, Bawa used a variety of forms to teach subtle mystical and philosophical doctrines to his American followers, including formal discourses (such as discussions on the origin of the universe and human beings, the path of return to God, with its states and stages, the batin and zabir meanings of the salat prayers and dhikr), ${ }^{34}$ devotional teaching songs and artwork as a visual means to core teachings. Among the community activities Bawa instituted were the practices of salat prayers, jum'a prayers, celebrations of Ramadan, zakat al-fitra at the end of Ramadan, the Eids, mawlids in honour of the Prophet and of the Qutb/Muhaiyaddeen, and devotional visitation to Mecca ('umra). While he did give many public talks outside of Philadelphia, most of his discourses took place in the meeting room of the Fellowship house in Philadelphia; many were given in his bedroom, even as his health declined. 


\section{Third-wave Sufism in America and the Bawa Mubaiyaddeen Fellowship}

Bawa did not appoint a shaykh to succeed him, and since his death in 1986, the function of transmission of his mystical teachings has been continued through the 'elders' of the community, ${ }^{35}$ using the vast archives of Bawa's videotaped and published discourses. He had appointed, however, two imams to lead jum'a prayers, one from Sri Lanka and one from the United States, instructing them 'not to use the khutba to beat people, but to melt their hearts'. Among the weekly activities of the Fellowship are Sunday meetings (which focus on Bawa's wisdom teachings), Friday jum'a prayers, salat and early morning dhikr in the mosque, children's meetings, Friday night dhikr instruction and practice, and regular readings and discussion of Bawa's work.

Beyond the mosque activities in Philadelphia, Fellowship activities are also held at the community's farm in Unionville, Pennsylvania, which Bawa had directed the community to purchase for three functions: a farm for community life and teaching, a burial site for Muslims and a mazar for Bawa Muhaiyaddeen.

As in Sri Lanka, Bawa used farming and cooking to teach community skills, service and charity as members were instructed in the parallel spiritual work of cultivating the spiritual virtues, the divine names and attributes, and remembrance of God with every breath. Instructions on the characteristics and qualities of food (physical and spiritual) became another focus of discourse (which included the metaphor of shaykh as cook - who knows the particular 'seasonings' and spices needed by each disciple in his transmutation to the al-insan al-kamil). ${ }^{36}$ The farm also became a venue for outdoor family camp weekends and retreats. Thus on a given 'unity weekend' the community will intersperse the cycle of salat prayers, the requirements of the physical farm and cooking/serving of food, videotape and practice of Bawa's teaching of the silent (or aloud) dhikr, and discussion groups on spiritual teachings. A number of Fellowship members live near the farm and have organized a branch community in that area.

Bawa had also directed the purchase of the farm in order to provide a burial site for Fellowship members and for the shaykh himself. Since Bawa's death in 1986, the traditional, simple mazar has become the centre not only for 'urs prayers, songs and Quranic recitation in honour of Bawa, but it has become a pilgrimage site for Sufis and Sufi shaykhs from other tariqas. In the last decade, the mazar has increasingly become a pilgrimage and family gathering site for diaspora Muslims, mostly Turkish and Indian. These recent immigrants did not know Bawa, but come in order to participate in their local cultural traditions, where family gatherings - picnics, songs and prayers - are often shared near the site of a saint. ${ }^{37}$

The cemetery has provided a burial site for 'Bawa's children', with several of the earliest members of the community now passing away. Again, with increasing numbers of immigrant Muslims, the situation has arisen wherein persons who did not know Bawa' will request to become members of the mosque community so that they may have a proper Islamic burial for themselves or their family in the Muslim diaspora.

\section{Outreach - local and global, sacred and political}

In the late 1980s the Fellowship was invited to send participants to a city-wide commission on interfaith relations, along with formal representatives from all major faith 
communities: Catholic, Episcopalian, Lutheran, Methodist, Jewish and others. This was the beginning of the Fellowship's inclusion in formal interfaith dialogue in Philadelphia and the United States. The larger Philadelphia religious community thus began to see and use Fellowship representatives as articulate spokespersons of 'traditional Islam' (in contradistinction to the 'cult' caricature prevalent in the 1970s and even currently among some right-wing Christian groups on the one hand, and the anti-Islamic caricature of Sufism and Bawa by Wahabi Muslims on the other). The Fellowship is asked regularly to send members to schools and community gatherings to speak about Islamic religion and to host university student groups wishing to visit the Islamic Friday prayers. The media began to contact the Fellowship when any event related to Islam needed reportage, a situation that became heightened in the months after the World Trade Center bombings when local churches and civic associations across the country were now asking for speakers on Islam and for dialogue with Muslims.

Indeed the relationship between the Fellowship and the media actually had its beginnings during the late 1970s with the Iranian Revolution and the taking of American hostages. Fellowship members recall Bawa's anger at Khumaini's presentation of Islam and at the taking of American hostages. They also recall their surprise when he began a letter-writing campaign to several world leaders involved in the Middle East crisis from 1979 to 1981. Bawa had all along emphasized the drama the jungle - of internal human forces driving the greed, violence, injustice and disunity in the world, but his engagement in the political realm was a new turn. His repudiation of Khumaini's 'Islam' was quoted (and pictured) in Time Magazine. His letters were compiled in a 1980 publication, The Truth and Unity of Man ${ }^{38}$ (now out of print); they include the strong criticism of Khumaini for damaging Islam and a plea to return to the compassion and brotherhood of Islam (referring to the nobility of early Islamic figures, such as Muhammad and Ali) ${ }^{39}$ Interestingly, Bawa's letters also included criticism of the UN Security Council's weakness in allowing the will of the world's nations to be dismissed by one vote. ${ }^{40}$ In his now famous Islam and World Peace, ${ }^{41}$ Bawa not only gives a Sufi understanding of terms such as salam, jihad, ijtihad and the Inner Qur'an, but he presents an outline of the history of the most famous example of strife among the children of Abraham, Jerusalem. While maintaining that establishing inner peace (salam) within oneself is the only effective road toward world peace, ${ }^{42}$ he nevertheless makes an appeal for an 'outer' United Nations Peace Force to be sent to maintain border security between 'the two lands'. ${ }^{3}$ Thus, while Bawa's focus was on teachings to heal and transform the 'inner self', his concern for 'God's justice' prompted involvement in the global arena, forming a precedent for a number of Fellowship members since Bawa's death. One does not find the community taking on political commitments as a group (perhaps necessarily, in that there are varying political perspectives in the Fellowship along race, class, gender and religious backgrounds), but rather as individuals. This includes involvement and leadership in various international peace and justice organizations (e.g. Muslim Peace Fellowship, Global Security Institute, Fellowship of Reconciliation, the 2001 International Conference against Racism in Durban, South Africa, the Council for a Parliament of the World's Religions, the Progressive Muslims network, and Muslim 
women's human rights and peace groups). A particularly important legacy of the peace and justice - and outreach - component of Bawa's work that has been continued by the Fellowship since his death is the visitation of prisoners and the 'free book program for prisoners'. The Fellowship has been in contact with 8000 prisoners over the years, many of whom communicate their reflections on their studies (and appreciation) of Bawa's discourses through letters, which are periodically read at Fellowship meetings.

The 1990s saw an evolution of inter-Sufi gatherings (including Sufi women's gatherings) in which Fellowship members (including leadership) have participated. The Fellowship also became participants of the inter-Sufi and inter-Islamic Internet linkages. An example of inter-Sufi, intercommunity support took place in the winter of 2001 as a public benefit was held at the University of Pennsylvania to raise funds for the publishing of Bawa Muhaiyaddeen's Resonance of Allah. The Rumi poetry recitation (by Coleman Barks) and musical concert brought together performers from various Sufi groups, as well as audiences from Sufi groups on the East Coast and the public at large.

The particular role that the Fellowship has come to play in Sufi/orthodox Islam relations in the last decade is exemplified in the development of the Islamic Educational Foundation - a conservative Muslim educational centre (for children as well as adult education) that was built in the main line suburb of Villanova, just outside of Philadelphia. The Bawa Muhaiyaddeen Fellowship played an important role in the township's approval of the project through its participation in zoning meetings and its assuaging the public's fears about 'Islam'. Although the Fellowship and the Foundation do not agree on theological or historical issues related to 'Sufism' they have struck a rapprochement, with their communities sharing inter-Islamic activities (such as the Eids) in spite of their differences.

\section{Conclusion}

The Bawa Muhaiyaddeen Fellowship presents us with a microcosm of the dynamics of Sufism in America. Bawa Muhaiyaddeen can be seen as a twentieth-century example of the tradition of the popular Sufi teacher of South Asia, who taught the mystical dimension of Islam to regions well-beyond the geographical origins of Islam. Moreover, Bawa brought to his Sri Lankan and American followers the Sufi tradition of the qutb, which he equated with both the ongoing cosmic process of divine illumination through the 'prophets, qutbs and saints' and, perhaps, more strikingly, through his own role as qutb and reviver of the faith (mubyi din) of this era. It is evident that his charisma, his loving relation to his followers, his consistently saintly example, and his wealth of knowledge of oral and literary traditions of wisdom contributed to the development of a longstanding community of Sufi followers in the West. The community has gone through a number of stages in its relationship to the larger community of Muslims and Sufis, ultimately accommodating both 'hybrid' and 'perennial' orientations of Sufism as well as non-Sufi Muslims who see the Fellowship mosque as a culturally integrated, 'non-taqlidi' ${ }^{44}$ expression of traditional Islam. While the number of members in Philadelphia who define themselves 
as Bawa's students has held steady at about one thousand, with several small 'branches' of members around the country (and Canada), the mosque community has increased steadily as the Muslim population in the United States increases through conversion and immigration. While Bawa gave many directives in terms of leadership and established a Board of Directors and an Executive Committee to vote on policies, the coming years will inevitably pose the question of transference of leadership, power, decision making and interpretation of teachings beyond the early group of Fellowship members. What is clear, however is that Bawa's legacy as a teacher of both the 'mystical dimension' of Islam (the establishment 'in the heart' of a primordial state of unity beyond race, class and religion) and the exterior dimension of Islam (the establishment in the community of a 'house of God' for traditional Islamic prayers and rituals) has created a welcoming space within the North American setting for Muslims and non-Muslims who seek progress at both the personal/spiritual and political levels. This legacy has been a significant alternative voice in the post-9/11 discourse on Islam available to the American public.

\section{Notes}

1 Annemarie Schimmel, (1978), pp. $23 \mathrm{ff}$.

2 Gisela Webb, (1995), pp. 249-250. For a detailed discussion of the Bawa community through the early 1990s, see Webb, Gisela (1994), pp. 75-108. The current piece provides some update on the earlier work.

3 See James Morris, (1992).

4 This situation can be seen in any of my 'Introduction to Islam' classes, which in my university (Catholic, located near Newark, one of America's immigrant hubs) usually means about 18 students, about one-third of them Muslims from a variety of regions of the world. The day we begin discussions on their assigned readings on 'Sufism, the mystical dimension of Islam', I have a variety of responses: a happy sigh from my Italian-Cambodian American male student with his Essential Rumi in hand - Rumi and Sufism being the reason for his taking the course; an unhappy sigh from one of my Pakistani American male students who identifies himself as a member of the Islamist 'khalifa' movement and declares Sufism as 'unorthodox'; a strong statement of agreement from my African American Muslim female student (a recent convert to Islam and the only female Muslim in bijab), who declares that her local imam (a former Pentacostal minister) said in a kbutba that Sufism is not Islam; and a positive response from my second-generation immigrant Afghani American female student who says she never heard about Sufism directly in her conservative Muslim family, but she says she hears themes about devotion that reflect her own upbringing and feelings, likes what she has read and wants to learn more so she can include Islamic spirituality in the 'religion classes' she conducts for young female Afghani Americans in her mosque community.

5 This is an example of M. Hermansen's 'perennial' designation.

6 Webb (1995), p. 253. See also the Biography of Pir-O-Murshid Inayat Khan. London: EastWest Publications, p. 107. Given Hazrat Khan's articulation of Americans' aversion to things 'Islam', one must consider to what extent Hazrat developed his 'universal' teachings and dances - and distancing himself from Islamic religion - as a pedagogical necessity given the political and social realities of his host country.

7 Webb (1995), pp. 257-258.

8 See R. Kamentz, (1995), for Rabbi Zalman Schachter's discussions with the Dalai Lama on the subject of Jewish spirituality, 'Jewish-Buddhists', and survival in the diaspora. See Bawa Muhaiyaddeen (1991), pp. 17-22, for record of Rabbi Schachter's discussions with Bawa Muhaiyaddeen. Several of Thomas Merton's works involve Christiann - Buddhist themes. 


\section{Third-wave Sufism in America and the Bawa Mubaiyaddeen Fellowship}

See recent work on Merton's Sufi studies, Baker, R. and Henry, G. (eds) (1999). Probably more than any other Muslim intellectual in America, Seyyed Hossein Nasr - with his approach to Islam, Sufism and 'traditionalism' - created a bridge for western academic and lay audiences, to Islam and Sufism as he presented a sophisticated ontology of a 'transcendent unity of religion', based on the work of the sixteenth-century Mulla Sadra's (and other advocates of traditional Islamic theosophical and wisdom literature), that could embrace an essential unity of religion as well as the authenticity and authority of the particular religions that had emerged in history.

9 Marcia Hermansen's 'hybrid' model in this volume.

10 See Rabia Terri Harris (2000), pp.172-194; Ibn al-Husayn al-Sulami, trans. Tosun Bayrak al-Jerrahi (1983); Muhyiddin Ibn 'Arabi, trans. Tosun Bayrak and Rabia Terri Harris (1992); Gwendolyn Zoharah Simmons, (2000), pp. 197-225.

11 Other examples of 'hybrid' Sufi groups in the United States (see Chapter 1 in this volume) include the Ni'matu'llahi and the Naqshbandi communities, the latter perhaps the fastest growing since the 1990s. See Chapters 2 and 6 in this volume.

12 Indeed, Bawa Muhaiyaddeen took members of his group to visit Pir Vilayat Khan at the Abode of the Message and had numerous dialogues with Shaykh Tosun Bayrak and other members of the Jerrahiya order, including the late Lex Hixon, a well-known spiritual movements radio commentator of the early 1970s, later a Jerrahiya member who was given permission by Seffer Efendi in Istanbul to lead a somewhat less traditional Jerrahiyya group of dervishes in New York City.

13 Linkages across Sufi and non-Sufi Muslim groups and individuals groups across the globe can be seen in the emergence of the Muslim Peace Fellowship, an international Islamic peace studies and advocacy organization, now under the umbrella of the interfaith Fellowship of Reconciliation, with its Internet site and newsletter, As-Salaam Alaykum, under Rabia Terri Harris and Zaineb Istrabadi of the Jerrahiyya order. See Safi, Omid (ed.) (2003). See also Wolfe, Michael (ed.) (2002).

14 'Qutb' refers to the highest spiritual authority in the hierarchy of saints, the pole, or 'axis', the 'help', 'ghauth'. See Schimmel (1978), particularly pp. 200-208. Research on Bawa Muhaiyaddeen has been made possible by access to the archival materials of the Fellowship (audio and video recordings of Bawa's discourses, songs and community events) and the living memories of Fellowship members, including older followers from Sri Lanka (now in their sixties, seventies and eighties) and early American members of the community. The publication of The Resonance of Allab has been particularly valuable in clarifying elements of Bawa's teachings in Sri Lanka, unavailable in my previous work. See Webb (1994).

15 Sufi Shaykh Muhammad Raheem Bawa Muhaiyaddeen (2001), K. Ganesan, trans., published originally in Tamil in Sri Lanka in 1969 under the title Allabvin Mulakkam.

16 One of the elders from Sri Lanka described her as being a regular visitor of pilgrimage sites, 'searching for a good teacher and healer'. She had an inner experience of hearing the La ilaba illa Allab repeated within herself, not knowing what it meant (as she was a Hindu) until someone translated it for her.

17 There are accounts and photos of Bawa Muhaiyaddeen going back to the early 1900s, putting Bawa at perhaps near 100 when he died in 1986, but Bawa's followers are hesitant to speculate on his chronological age.

18 Prior to the founding of the ashram Bawa spoke to small groups in the homes of patrons; the ashram had an open-air structure - foundation, roof, no walls - for teachings/meetings, the model he followed later at the American Fellowship farm.

19 The series of volumes entitled Wisdom of the Divine (Vol. 1-6) have been published through the Serendib Sufi Study Circle, and reflect Bawa's commentaries/teachings on traditional Sufi doctrines, e.g. the transcendent unity of religions, the Sufi understanding or the hadith qudsi, 'he who knows himself knows his lord', the 'fana'/'die before death' experience, the spiritual stations, the kaabalqalb as seat of wisdom.

20 The particularly warm relationship to his followers is evident in the opening words to every discourse: 'My love you my children, jeweled lights of my eyes.' 
21 The tradition of the heart-as-locus of intimate colloquy with God is an important Sufi theme since the time of Tustari (d. 896) - as is the 'theology' of the light of Muhammad. See Schimmel (1978), p. 417. Metaphysical theories positing powers of Being (in the language of the angel, light, wisdom) that mediate the ontological and epistemological 'distance' between divine and human being and knowing are also present in the philosophies of Ibn Sina and Suhrawardi (al-Maqtul).

22 Bawa Muhaiyaddeen (2001), pp. 3-8, including footnotes 3-21.

23 See Webb (1994), p. 86 for Bawa's use of the theory of the 'mims', the letter $m$ 's, of Muhammad's name. See also Schimmel (1982), p. 194 and Schimmel (1978), pp. 419-420.

24 A reference also to the Quranic 'Day of Alastu', (Sura 7:171), the event in primordial time in which human beings testified to their knowledge, their 'recollection' of their Lord, associated with the eternal dhikr in the hearts of human beings.

25 A reference to the hadith qudsi, 'He who knows himself (lit.'his-self') knows his lord'. The call to analyse and answer the question 'Who am I?' is at the beginning of several of Bawa's works/discourses. It is an analysis of the seven levels of consciousness, reminiscent of both yoga psychology and the theories of the 'states and stages of the path' leading to fana - the state of 'dying before death' - prominent in Sufi literature. See See Bawa Muhaiyaddeen (2001). His Holiness M. R. Bawa Muhaiyaddeen (1977), p. 1. His Holiness Sheikh Muhammad Muhaiyaddeen Guru Bawa (1971), Vol. 1, p. 83.

26 See Bawa Muhaiyaddeen (1983), pp.17-18, 85-88, for the role and activities of the shaykh, which utilizes father and mother imagery. The allegory of the $Q u t b$ in the Maldive Islands refers to the 'divine analytic wisdom' within the individual (including the dimension of Bawa Muhaiyaddeen as 'Shaykh/Qutbiyyat' in this process) that travels through all the recesses, the infinite oceans of being, the inner and outer worlds, to analyse and illuminate one's state, one's imperfections, how to progress, how to fight the 'ghosts', 'demons and 'idols' within the self. Bawa also used mining and jeweller metaphors, for example, the jeweller who cuts the impurities away from the pure diamond within. See Webb (1994), p. 92, n. 57.

27 See Bawa Muhaiyaddeen (1979), with its discussion on the four steps to pure faith of shariat, tariqat, marifat, sufiyat, and Bawa (2001) for the seven stages of consciousness. See Webb (1998).

28 Bawa Muhaiyaddeen, 'The One Who Rules Baghdad' (Tape 5 - Songs, Philadelphia: Fellowship Press), elucidates the teaching. Bawa's followers consider Bawa a living presence, still the qutb of the age. Remembrances of the development of these teachings vary among community members. One member said that in looking back, 'Bawa taught us in reverse order than most Sufis, with the inner dimension first and then the outer'. Another member said, 'I was here for five years when one day Bawa said, 'This is Islam.' Another said with certainty, 'Bawa's teaching has been the same since the beginning.'

29 For a more detailed description of the dhikr Bawa taught, see Webb (1994), pp. 82-85 and 94-95. The silent $t$ dhikr includes the process of ablutions, recitation of the Quranic Suras Fatiba, Nas, Ikblas and Falaq, practising a rhythmic recitation of the La ilaba illa Allah while focusing on left and right body/breath until 'there is no other'. The traditional association of 'the left' with the negative pole and first part of the kalimah (La ilaha) and 'the right' with the positive pole of the kalimah (illa Allah) can be seen in much of the vernacular poetry of the Qadiriyya, as pointed out by Schimmel (1982), p. 143. The aloud dhikr consists of litanies of traditional formulae, e.g. the Names of God, the La ilaha illa Allah.

30 The mosque would bring traditional gender distinctions in the use of social space, with men in the front and women behind them, a lace curtain separating them. Members say that in consolation for this new separation, Bawa designed the space so the transparent dome would be over the women's area. In Bawa's discourses until this time, men and women were in the same room, though one can see from videos that although there is no barrier between men and women, and no 'hierarchy of proximity', the women and men are generally in different spaces in the room. Women have had leadership roles in the fellowship teaching and administration - from the beginning, including president. The mosque imams appointed by Bawa were of course male, one American, one Sri Lankan. 


\section{Third-wave Sufism in America and the Bawa Mubaiyaddeen Fellowship}

31 Distrust of the Bawa Muhaiyaddeen Fellowship came both from Muslims who reject Sufism as a legitimate expression of 'orthodox' Islam (e.g. Wahhabi) and from conservative Muslims who rejected Bawa on the basis of his not being a 'traditional' enough Sufi (e.g. too 'Hinduistic', no traditional silsila).

32 See the Turkish journal Hoca Abmet Yesevi Ocagi (2/24/2000), Ankara, pp. 31-33.

33 There are a number of recorded discussions where conservative Muslims would approach Bawa with consternation and concern that with the focus on the inner dimension of Islam, people might not do the 'outer' requirements of shari' $a$ and 'ibadat. One man who presented Bawa with this charge - interspersing it with numerous quotations from the Quran in Arabic - received a discourse from Bawa consistent with traditional Islamic theology: ' ... the Quran is not just commanded: it is the Rahman of Allah .... No one can bear and lift up the Quran .... No one can even say one alif in the whole world .... The Haqiqat Muhammad is Allah's Face .... No one can ever finish reciting the Quran .... If all the oceans were made into ink and all the trees made into pens, ... the Quran could never be finished .... Nothing would be created without you, Muhammad .... Allah is one alone. All belongs to Him. What do you have that belongs to you? When this is understood, you have iman.' Audio Tape ARS 7508-03, 8/75, 'Iman-Islam'.

34 Titles of the discourses and songs are telling of their contents and their function in the community, e.g., On the meaning of the Quran and the mi' raj experience: 'The Stages of Ascendancy', 'The Meaning of the Suras' (8.26.76 APT7608-03); Devotional songs: 'Eternal Prayer' 9.1.74. ARS 7409-01, 'First Muhammad Song' 11.9.77 ARS 7711-04, 'The Qalb, the Island of Serendib' 10.11.75 ARS-74-0802; On Bawa's teachings on his vision of the meaning and building of the mosque: 'Bawa Muhaiyaddeen's (Ral.) vision of building the mosques in Mankumban and Philadelphia' 8.24.79, 'Laying the cornerstone: God gives his Rahmat according to the age and maturity of each being. Learn arn 'ilm and know the taste of prayer, worship, and ibadat' 11.14.83 (Tape 1 of 8, 790824-01 MOSQ). The audiotapes are in the process of being transferred to CDs in the archival work of the Fellowship.

35 Administrative decisions are according to By-Laws set up by Bawa in 1973, which defined duties and functions of an Executive Committee, Board of Trustees and General Council. One does hear discussions in the community of the need to integrate new members/new approaches/new leadership to meetings and other functions in the community as the Fellowship enters its fourth decade.

36 The cooking metaphor was of course used by Rumi and other Sufis. Coleman Barks, the most prolific of Rumi's new translator/interpreters attributes his vocation to Bawa's influence, and in Bark's The Essential Rumi, not only mentions this, but presents some of the recipes taught by Bawa and which are still used in cooking for Fellowship gatherings, Sunday meetings and Friday post-juma' meals. See Barks (1994), pp. 292-295, as he quotes Rumi speaking of the Friend (God or the shaykb): 'You think I'm torturing you. I'm giving you the flavor so you can mix with rice ... and be the lovely ... human being.' Bawa's recipes and discussions on food are compiled in Bawa Muhaiyaddeen (1981), Tasty Economical Cookbook. Vol. 2. Philadelphia: Fellowship Press, pp. 1-6.

37 Among the new immigrants from India who have adopted the Fellowship as their mosque community, apparently because of cultural commonalities to and familiarity with Islamic spirituality, are Gujaratis and Ismaelis.

38 Bawa Muhaiyaddeen (1980).

39 Bawa Muhaiyadeen (1980), pp. 8-23, 45-61.

40 Bawa Muhaiyaddeen (1980), pp. 65-66.

41 Bawa Muhaiyaddeen (1987). This text has become increasingly in demand as the enquiry for information on Islam has increased nationally since the events following 'September 11'.

42 Bawa Muhaiyaddeen (1987), especially the final chapter, 'Everyone Is Speaking About Peace'.

43 Bawa Muhaiyaddeen (1987), p. 22.

44 Taqlid is the Arabic (and Sufi) term denoting theological and jurisprudential rigidity. 


\title{
5 Transnational Sufism
}

\section{The Haqqaniyya ${ }^{1}$}

\author{
Jorgen S. Nielsen, Mustafa Draper and \\ Galina Yemelianova
}

\section{Introduction}

Sufi tariqas are, in many respects, unique communities, not only in the diversity of structures and theologies, but also in their ability to adapt to social and cultural contexts. Integrating the theosophical and esoteric with the social and political, most tariqas have played, and many still play, a significant role in Muslim societies. In contemporary modern and postmodern contexts, the study of such communities is important as it facilitates an understanding of the adaptation of communities whose focus is essentially transcendent and whose interactions are increasingly transnational.

The tariqa of Shaykh Nazim al-Haqqani traces its origins to a branch of the Naqshbandiyya in Dagestan, where it functioned essentially as a regional Sufi cult. ${ }^{2}$ The subsequent translocation of three generations of shaykhs through Turkey and Syria, to Northern Cyprus and beyond, has led to the adaptation of the tariqa in each of these contexts and phases. The tariqa has, particularly under the direction of its present shaykh, extended its membership to many countries and has possibly one of the largest and most diverse international memberships of any Sufi tariqa. The diversity of its emphasis in all of these varying situations - political, eschatological, spiritual - sets it apart from other groups.

Previous research into this particular tariqa has focused mainly on single geographical contexts, in particular the $\mathrm{UK}^{3}$ and Lebanon. ${ }^{4}$ The extensive international networking of the tariqa suggests that there has been an increasing necessity to focus research on the interactions of these contexts and, additionally, to focus on the role of electronic networking via the Internet. Of special significance for this research is the way in which the present shaykh has succeeded in contextualizing the tariqa in these diverse situations while essentially maintaining the traditional elements and teachings as a focus of its identity.

The main aim of the project, the results of which the present contribution is an overview, was to 'broaden our understanding of how Islam functions across boundaries of state, communities and ethnic groups' and, within that, more specifically to find out how a Sufi order can adjust to a rapidly changing environment. Three locations were selected for fieldwork, namely Britain, Dagestan and Lebanon. The rationale for this selection was comparatively straightforward. The tariqa has its origins in Dagestan and later set root in Lebanon before travelling west, where Britain was its 


\section{Transnational Sufism}

first base. However, the different contexts of those three countries also gave us access to the tariqa in different relationships to modernity and change. In Dagestan, the political and socio-economic context meant that it existed in isolation from the transnational dimension of the tariqa while functioning within a situation of a large number of similarly fragmented Sufi groups. In Lebanon, the tariqa has been emerging from a civil war experience that had isolated it from its western development, which had started a few years before the inception of that war in 1975. It has increasingly been drawn into the transnational network which had appeared during the war. In Britain, the tariqa started in London but became fragmented as it established followings around the country, consisting variously of Muslims of immigrant origin and of a significant group of converts. The combination of particular common themes across the tariqa (attitude to political authority, looseness of definition of 'membership') and specific events (above all the millennium debate) provided us with the material to test the nature of communication across the network and a measure of the relationship between universal and local practice and expression in these three sites.

Apart from working through print, audio and video materials, the main source of information has been guided conversations and observation of the activities of the tariqa and its members in tariqa settings. At an early stage, we drew up a list of categories of people to be interviewed in each location and a list of the types of information we would be looking for through a process of semi-structured interviews. Given the nature of the tariqa and the circumstances of the locations, it quickly became clear that such interviews were not welcome and that they threatened to distort the field and thence our access. It was possible to tape some interviews in Dagestan, but in Britain and Lebanon it was not and notes had to be made after the event. These factors meant that the research went slower than had been anticipated but they were not, in the end, a significant obstacle to obtaining the kind of information we were looking for. Already before the project we were aware that Internet material had to be treated with caution, particularly as regards provenance. This was confirmed on several occasions during the project, when checks revealed that particular texts had been 'cuckoo-nested' on Haqqani sites by opponents.

Within the Sufi traditions of Islam the Naqshbandi tariqa (order) is one of the largest. Arising out of the teachings of the eponymous founder Khawaja Baha' al-Din Naqshband (d. 1389 CE), who is buried outside Bukhara in present-day Uzbekistan, the Naqshbandis attracted large followings particularly among Turkic peoples in Central Asia and the Ottoman Empire, in the Indian subcontinent and in south east Asia, becoming the dominant tariqa in some areas. Over time different subgroups appeared around particularly charismatic Naqshbandi spiritual guides (shaykhs). The Haqqani branch was founded by Shaykh Nazim al-Qubrusi al-Haqqani. ${ }^{5}$ He was born in Cyprus in 1922 and in 1945 was initiated by the Naqshbandi shaykh 'Abdallah al-Daghestani (d. 1973) in Damascus. He spent the following years preaching and travelling around the east Mediterranean where he attracted followers in Lebanon, Syria and Jordan. Two brothers of the elite Lebanese Sunni Kabbani family became his leading trusted aides and one of them, Hisham, became his son-in-law. A year after al-Daghestani's death, Shaykh Nazim went to Britain to start a mission in the west, and it is usually from this time that his Haqqani branch is dated as a growing 
number of disciples (murids) started to gather around him. In 1990 Shaykh Hisham moved to the United States, founding a branch of the Haqqani tariqa there. He and his brother 'Adnan, based in Tripoli, Lebanon, are widely regarded as possible successors (khalifas, a term used also to denote the leader of a local group) to Shaykh Nazim.

For the project, fieldwork took place on three sites: Dagestan, Lebanon and Britain. An historical approach would suggest that the three sites be dealt with in this order here. However, the events which took place during the period of research and which provided tests of how the tariqa functioned tended to start in the West and impact on Lebanon - and hardly at all on Dagestan. So it makes more sense to deal with the sites in the reverse order, before considering a number of overarching themes arising out of the fieldwork and the other elements of the research conducted by the team.

\section{Britain}

The origins of the tariqa's presence in Britain go back to when Shaykh Nazim first visited in 1974 on the instructions of his own shaykh, 'Abdallah al-Daghestani. He soon started attracting a number of followers of various ethnic backgrounds, including a number of white converts. A succession of properties were occupied until in 1992 a significant gift from the Sultan of Brunei allowed the purchase and modification of St Anne's in Tottenham. Shaykh Nazim continued to make regular visits, usually during Ramadan. These visits, and his relaxed attitude to the presence of both women and men in his meetings and to the performance of the seasonal rites, attracted followers who sought to set up local groups around the country. Of these, the two in Birmingham and Sheffield have been the most notable outside London.

The Birmingham group has had a succession of leaders (khalifas) and locations. It has shown a tendency to occasional factional splitting. The first shaykh was excluded for alleged 'indiscretions' but apparently retained personal links to Shaykh Nazim. His successor, formerly a member of a major locally based Naqshbandi tariqa, developed plans, ultimately disappointed due to lack of funding, for the establishment of a major Islamic centre of learning. He in turn was denounced in 1996 and, taking with him some of the following, moved his allegiance to another (Syrian) shaykh. He was replaced by a younger man (24 years of age). The group has for a some years been almost exclusively South Asian in membership, which most probably accounts for the fact that women's groups usually meet separately. The core membership of about twenty, mostly young men, is supplemented by much larger numbers, particularly from the extended families of the core members, when Shaykh Nazim himself visits. During such meetings there are usually reports of significant numbers of new followers declaring their adherence (giving bay'a). In the early years, the group attracted members of other tariqas, but since the appointment of the young khalifa in 1996 has mainly attracted young men of South Asian origin new to Sufism. The group has thus become much more of a youth movement with subsequent relative political radicalization, a change which was reflected by an often quite ambivalent attitude to the project.

The Sheffield group is based around a property whose purchase was arranged by Shaykh Nazim. Much of the internal dissent in the group is attributed to disagreements 


\section{Transnational Sufism}

over its administration and use, with the consequence that various sections meet for their own dhikr at various times. The Birmingham group has always assumed that their own failure to find funding for their centre was due to the problems in Sheffield. The Sheffield group has remained ethnically mixed with membership recruited from South Asian Muslims, Turks and white and Afro-Caribbean converts. The different internal groupings tend also to coincide with these ethnic distinctions. A predominantly Pakistani-origin male group meets Fridays for a closed weekly $d$ hikr led by a white convert, while another group, mixed in both ethnicity and gender, meets on Sundays in an open environment. The latter has good relations with the UK John Bennett group and have an annual joint meeting with a Sheffield-based neoshamanic group. This group is more oriented towards alternative forms of spirituality with recent connections to Glastonbury (see below).

The London part of the tariqa consists of followers from Turkish, South Asian and Western convert background. Only a few of the original leading followers of Shaykh Nazim remain with the group, some having become quite strong opponents, in part due to the failure of Shaykh Nazim's early predictions of the coming of the Mabdi. The London group is fragmented with no one overall khalifa, but rather several senior khalifas, each leading their followers in separate $d h i k r$ meetings. The whole group only comes together when Shaykh Nazim visits and stays in the apartment at St Anne's. The looseness of the group has given Shaykh Hisham in the USA an entrée to claim overall authority, a claim which he has during the research period been asserting over the whole of Western Europe. This claim is vehemently opposed by a number of the murids based in London, and seems to have little impact outside London.

In February 1999 Shaykh Nazim visited Glastonbury, where he spoke to a packed audience in the Assembly Rooms. Recognizing Glastonbury as the 'spiritual heart of Britain', he instructed a leading female follower to move there and set up shop. She opened a 'Sufi charity shop' and the locality started to attract a number of followers. Currently about twenty murids live in the town and attend weekly dhikrs. One series, monthly on Sundays, is led by the leading London-based khalifa and attracts a number of followers from London and Sheffield. Another group meets weekly on Thursdays but is claimed by some not to have the authority of Shaykh Nazim. In both cases, attendance by 'Pakistani brothers' is discouraged. The talks at the monthly meeting tend to minimize explicitly Islamic language, preferring the vocabulary of 'energy', 'breathing in light' and 'taking in the Divine', which is more often associated with new religious movements and New Age. In November 2000 a public 'whirling dervish' performance was held (a form of dhikr traditional in the Mawlawiyya [Mevlevi] tariqa), since when several other such events have been held. The November programme also included musical performances by various Haqqani groups from Britain, Germany and the Netherlands, apparently on the authority of Shaykh Nazim, who was reported to have authorized the use of music as a way of appealing to new recruits. The use of the Maulawi 'whirling' dhikr has provoked some internal discussion. Some local groups adopted it for their own use for a time while others opposed it and its use is now restricted to Glastonbury.

During the period of research two main phenomena have dominated developments. The major one was the millennium. Early in 1999 Shaykh Nazim started to 
relate his teaching on the coming of the Mabdi to events expected later in the year and into 2000. The main element in this forecast related to the major problems anticipated in the computer world, namely the two date issues of 9.9 .99 and, above all, the Y2K 'bug'. Other events were integrated into this discourse, particularly the earthquakes in Turkey and Greece and the solar eclipse across Europe. There was talk of murids going to Damascus or Lebanon to await the 'end days', or at least leaving the towns for the countryside. Some gave up college courses in anticipation, and a safe house was established in Norfolk. When nothing untoward happened, many followers became disoriented and refused to discuss the subject with the researcher. Shaykh Nazim himself remained in seclusion at his home in Northern Cyprus until August 2000 when he resumed his travels to Lebanon, Syria, the USA and elsewhere. By mid-2001 he had not yet visited Britain. The explanation most often given for the failure of the predictions is that God was persuaded by Shaykh Nazim's prayers to have mercy on humanity.

A regularly disruptive element has been the appearance of 'false shaykhs'. One such, a Shaykh Na'san, a Syrian, appeared in Britain in the spring of 1999 claiming to be acting on the authority of Shaykh Nazim, seeking to dissuade murids from leaving their homes in response to the forecasts of the coming of the Mabdi. For a time there began to develop the kind of cohesion across the groups which had hitherto been lacking in the absence of a resident 'national' khalifa. But while Shaykh Na'san appeared to have gained the adherence of the small groups in Coventry and Slough, his credentials were increasingly being challenged until finally in the autumn Shaykh Nazim made it clear that he had not given this man his authority. During September 2000 another claimant appeared, an ex-murid, recruiting disciples on the authority of Shaykh Nazim, in particular targeting the Glastonbury base. In both these cases the Internet, through mailing lists and newsgroups, was the main medium by which the 'false shaykhs' were exposed.

\section{Lebanon}

As part of the cultural region often called 'greater' or 'geographical' Syria (bilad al-sham) the religious environment of Lebanon has much in common with the larger region, especially in its Sufi traditions. Although with special strengths in the countryside in this region, Sufism has also historically had a marked presence in towns and cities. In an ethnically diverse region such as this, the Sufi traditions are also diverse with virtually all the main traditions represented and none being dominant. The Naqshbandi tradition has on the whole been associated with ethnic groups such as Turks and Kurds, while Arabs have tended to gravitate in particular to the Qadiriyya and Rifa'iyya. ${ }^{6}$ The twentieth-century process of urbanization and the disintegration of the Ottoman Empire seriously weakened the Sufi networks in the region. ${ }^{7}$ But, as in the rest of the Arab world, urban Sufism has seen something of a revival since the 1960 s, although often with greater emphasis on individual piety than on the organized structures of the traditional tariqas, but still frequently in a relationship of spiritual guide (shaykh or murshid) to disciple (murid).

Shaykh Nazim first established a following in Lebanon during the 1970s, working out of his home in northern Cyprus. Two brothers of the elite Sunni Kabbani family 


\section{Transnational Sufism}

(a distant relation is currently Chief Mufti of Lebanon), Hisham and Adnan, became his leading disciples in the country. During the civil war period, 1975-1990, Shaykh Nazim's preaching gained a growing following, as did that of a number of other shaykhs, appealing to people tired of the depredations of civil war. During this time the centre of the group's activity moved from Beirut to Tripoli. By the late 1980s Shaykh Nazim's attentions were increasingly devoted to Europe, and in 1988 he visited Lebanon for the last time in a decade. Two years later he sent Shaykh Hisham Kabbani to the United States to start a new mission there, drawing attention even further away from Lebanon.

When Shaykh Nazim again visited Tripoli in 1998 it was to find a much depleted group of followers around Shaykh Adnan Kabbani. Our research suggests that the active core does not consist of more than about twenty people. This rises to about 70 when Shaykh Nazim visits, as he did again in May 1999 and in August-September 2000. However, there are larger numbers who seek to meet him during such visits without taking part in the more formal sessions of the tariqa. Another group of about the same size regularly meets in Beirut, led by a distant cousin of Shaykh Adnan. There are few relationships between these two Lebanese groups and the three others existing in this part of the Arab world, namely in Damascus, Aleppo and Cairo, apart from during visits by Shaykh Nazim when some followers from elsewhere will travel to meet him. This also means that each local group knows very little about any of the others and tends to attribute much greater success to the tariqa elsewhere ("thousands of followers in Aleppo'), a tendency which is strengthened by the very wide concept of adherence adopted by Shaykh Nazim and his immediate entourage. Even within the local group there is hardly any individual contact between members outside the regular meetings, probably due to the very different occupational backgrounds of the core membership.

In Lebanon in Sunni Muslim circles Shaykh Nazim is probably the best known of the various Sufi shaykhs with followers in the country. Personally he appears to be on good terms with several of the other tariqas and during his 1999 visit attended a prayer circle of the Rifa 'iyya in Tripoli. But he also has opponents, first and foremost among the salafis. However, the most active opposition probably comes from the Association of Islamic Charitable Projects, popularly known as al-Ahbash, one of the largest Islamic movements to grow out of the civil war, described as an activist pan-Sufi movement. ${ }^{8}$ While its main arguments are with the salafis and the Muslim Brotherhood, it has launched some virulent attacks on Shaykh Nazim's teachings based on their alleged transgressions of core Islamic teaching and practice. These attacks have been published both in print and on the Internet. ${ }^{9}$

It was primarily through the Internet that the millennium discourse reached Lebanon and attracted a good deal of local media attention. In May 1999 the news started circulating that Shaykh Nazim had called on his followers to gather in a Lebanese mountain village to await the coming of the Mabdi at the turn of the millennium. Some European and US followers did converge on the village in question much to the consternation of the inhabitants and the security services. A further complication appears to have been that the village was the property of the Kabbani familyclan, and the main sections of the clan took legal action against Shaykh Adnan and 
other followers to assert their ownership rights. When the millennial predictions were not fulfilled in 2000, it was a major blow to the group's reputation and that of its leaders, especially Shaykh Nazim. This appears to have been a final factor contributing to the marginalization of Shaykh Nazim's tariqa in the region.

\section{Dagestan}

The context in Dagestan is strongly influenced by the consequences of generations of interaction between the Islamic traditions of the region and Soviet policy towards them. Traditionally Sufism, especially in the Naqshbandi form, has been the dominant expression of Islam, and the population is very self-consciously Sufi. Isolation from the broader developments of the Muslim world, both during the Tsarist and the Soviet periods, has tended to favour religious exclusivity and strict adherence to the disciplines of the various tariqas. At the same time the ethnic diversity of Dagestan has allowed for the rise of ethnically defined tariqas, a link which has also encouraged political activism. Such fragmentation did not, however, prevent a degree of boundarycrossing between Naqshbandis and various other tariqas, particularly the Shadhiliyya and Juzuliyya. Thus Naqshbandi shaykhs were among the leaders of resistance to Russian expansion during the eighteenth and nineteenth centuries. ${ }^{10}$ Under Tsarist and then Soviet rule the Sufi orders were subjected to sustained attack, including killings and deportations to Siberia. Many fled, including Shaykh Abdullah al-Faiz al-Daghistani, the shaykh of Shaykh Nazim. The fragmented nature of Dagestani ethno-political loyalties meant that some shaykhs were persuaded to work with the Soviet state against the continuing manifestations of unofficial Islam. When the Soviet system collapsed, Dagestani Sufis emerged from the underground and championed the grass-roots re-Islamization of the region. Out of the multiplicity of Sufi groups, that led by Shaykh Sayyid Effendi Chirkeevski (Naqshbandi) emerged as the de facto representative of official Islam in alliance with two main ethnic political groupings, namely the Avars and Dargins which have dominated post-Soviet Dagestani politics. This enabled Shaykh Sayyid Effendi to shape government opposition to the post-Soviet growth of Salafi movements, significant given their strength in neighbouring Chechnya, as well as disapproval of alternative Sufi groups. ${ }^{11}$

These circumstances have provided a very uncertain environment for the small group of followers of Shaykh Nazim. The multiplicity of Sufi and ethnic groups provided space for Shaykh Nazim to seek a foothold in Dagestan. His first and only visit took place in August 1997 at the invitation of Nadirshakh Khachilaev, an ethnic Lak who was at the time a deputy in the Moscow Duma and leader of Russia's Union of Muslims. The alliance was primarily one of political convenience in that it provided Shaykh Nazim with local sponsorship and in return potentially lent Khachilaev Sufi support in his campaign against Avar/Dargin dominance. In May 1998 Khachilaev's alleged involvement in an attempt to storm the Parliament building in Makhachkala ended his political aspirations and marginalized the small number of Shaykh Nazim's supporters. Among the various Sufi groups opposed to Shaykh Sayyid Effendi, that of Shaykh Nazim is particularly exposed to government repression. $^{12}$ 


\section{Transnational Sufism}

Shaykh Nazim's followers in Dagestan can hardly be termed an organization and are a tariqa only in a very vague sense of sharing some form of spiritual adherence to the Shaykh. There is a khalifa in a suburb of Makhachkala, but his links with other members are minimal. The number of adherents is several hundred according to the statements of murids interviewed, but only a few dozen according to outsiders. However, there is a wider acceptance and respect of his position as one among several valid shaykbs. Due to their isolation the few Haqqanis of Dagestan did not participate in any of the discourses which took place elsewhere in the tariqa during the period of research. Only a few circulating audio- and videotapes contribute to a shared discourse, apart from the occasional exchange of visits among different parts of the country. Such religious rites as do take place are in the traditional Naqshbandi forms of the region. The ethno-political fragmentation finds its equivalent in Sufi arguments over rival chains of inherited authority (silsila). The official line of Shaykh Sayyid Effendi is that he is the only legitimate heir of the Naqshbandi tradition in Dagestan, while opponents allege that his silsila is a forgery of one of the 'Red shaykbs' who supported the Bolsheviks. Among these opponents there are also rival silsilas in circulation. ${ }^{13}$

The teachings of the Dagestani followers of Shaykh Nazim are explicitly 'nondoctrinal'. The research suggests that this may in part be due to the absence of detailed Islamic education resulting from Soviet-era policies; the members certainly have only a very superficial knowledge of Islamic precepts or texts, even those which are most closely associated traditionally with the Naqshbandis. But the group also has an explicit policy of inclusiveness. This finds expression in their willingness to take part in the rites of other Sufi groups, sharing visits to the mausoleum of earlier shaykbs, and following Shaykh Nazim's example of easy access to adherence. While these characteristics become accusations against Shaykh Nazim's followers on the part of the 'official' Sufis of Shaykh Sayyid Effendi, they are further reason for the respect in which he is held by many 'opposition' shaykhs.

\section{Common themes}

The first question which most strikingly arises out of the research is the nebulous nature of 'membership' of the tariqa, or the 'following' of the shaykh, giving rise to very different assessments of the size of the tariqa. Fieldwork and other accounts regularly confirm the ease of expressing adherence, or giving bay'a, to Shaykh Nazim. We have seen and heard of numbers of occasions on which he has invited and accepted the bay'a of dozens of people, not to mention reports of public meetings with hundreds of people present. This ease of adherence contrasts sharply with most other Sufi groups, including others in the Naqshbandi tradition. The borders of the tariqa are porous also in the sense that only in the cases of the 'false shaykbs' have we recorded any form of official 'expulsion'. Most departures go unnoticed, often in the sense also that someone who has given, or is said to have given, bay'a does not follow up that initial contact and is not again seen in connection with the tariqa. By coincidence, the three research sites share an environment in which the processes associated with establishing some form of organization are minimal. Impressions from Germany and the USA suggest that the context in those countries (strong legal expectations of 
civil-society organizations in Germany, strong political expectations in the USA) encourages more formal concepts of membership and/or structures. Our conclusion is that 'membership' of the tariqa is best conceived of as consisting of three circles. The inner circle is the committed murids who consistently take part in the regular meetings for dhikr, a group which includes a small number of individuals who are in regular contact with Shaykh Nazim, often the local khalifas, and who form his 'entourage' when he visits. A second, much larger, circle is composed of those who attend tariqa functions only on special occasions, such as the major festivals. It is at its largest when Shaykh Nazim is present. A third circle, much smaller, is by its nature more difficult to identify and could be viewed as consisting of those individuals who look to Shaykh Nazim as some kind of spiritual model or guide without taking part in the collective activities of the tariqa. All of these, including the third circle, will at some time or other have given bay'a to Shaykh Nazim, but there are many more who have given $b_{\text {ay' }} a$ and cannot be regarded as being in any of the three circles, as their 'membership' has either lapsed or was never activated following the bay' $a$. The claims of spokespersons of the tariqa to large 'membership' numbers seem to be based on either the numbers of participants in the three circles or a cumulative total of those who have given bay' $a$ at some time; both calculations would by their nature be impressionistic and large. In terms of assessing the impact of Shaykh Nazim overall, one also has to take into account the widely held respect in which many Muslims hold 'holy men', men (it is very seldom women) who are somehow regarded as being 'touched by the sacred'. For this reason many people attending large public meetings to hear Shaykh Nazim cannot necessarily be counted as followers but are rather an expression of this respect.

Two topics of discussion within the networks of the tariqa have been of particular interest to the aims of the project as a test of how it coheres and how discourses move around the network. One, the question of relations with the political authority, has been a continuous theme in the history of the tariqa during the 1990s. The other, namely the coming of the Mabdi and the millennium theme, was peculiar to the period of research.

The activities and teachings of Shaykh Nazim and his key followers, particularly Shaykh Hisham, have regularly indicated an assumption that the legitimate authority of a state should be respected. The principle is not expressed explicitly in general terms but can be deduced from actions and responses in particular situations. Shaykh Nazim counts among his close murids senior members of royal families in Malaysia and Brunei, the latter having provided substantial financial support on a number of occasions. At the time of the death of Princess Diana, Shaykh Nazim on several occasions spoke in strong support of Prince Charles and blamed Diana's death, among other things, on her adultery. On the other hand, some quite abstruse arguments in Islamic law were mobilized to legitimize Prince Charles's relations with Mrs Camilla Parker-Bowles. In 1999 Shaykh Hisham shocked the majority of the Muslim community in the USA and its leading supporters by declaring to the State Department that most Muslim organizations were extremist and a danger to US security. ${ }^{14}$ During late 2000 and into 2001 Shaykhs Hisham and Nazim have made themselves available to the government of Uzbekistan in its endeavours to encourage a friendly Islam as a 


\section{Transnational Sufism}

counter to perceived 'fundamentalist' threats to the political order. ${ }^{15}$ This tendency has placed the groups in Dagestan and Lebanon, where the state is disputed, in a difficult position. In Dagestan, support for the loser in a struggle for political control contributed to the marginalization of the tariqa, while it was partly protected from a similar fate in Lebanon, following the return of Rafiq Hariri to the premiership, by Shaykh Adnan's membership of an elite Sunni clan.

The millennium discourse lasted about eight months in all, from the spring of 1999 until the beginning of 2000, and was then followed during the summer of 2000 by a lower-key process of reinterpretation. Since his early preaching in the 1970s, Shaykh Nazim has regularly returned to the theme of the coming of the Mabdi and imminent 'end of days'. In the mid-1970s he had on several occasions put a date to the event, but as the dates passed uneventfully he ceased this practice while continuing to talk of the end of the world in more general terms. The impact of the millennium discussion in Britain and Lebanon has been outlined above. Its absence in Dagestan has also been noted. The disparity was due to the fact that the subject was communicated primarily via the Internet, which is absent in Dagestan. In effect this made the Internet a fourth site of fieldwork, which had a marked impact also on the form taken by the tariqa in its electronic manifestation. Complementing the main outlines of the millennium events outlined previously was an extensive proliferation of texts and discussions that commonly had a minimal Islamic content. Often this content had much closer affinity to the content and language of New Age movements and, occasionally, of Christian survivalists; in one instance an extensive section of a Christian survivalist website's advice for the coming Y2K catastrophe was pasted verbatim and unattributed into a Nazimi website. After the failure of the predictions, the New Age themes of rural versus urban, nature versus technology, etc. have been strengthened as interpretations of what Shaykh Nazim was 'really' warning against.

The millennium events illustrate the uneven nature of the communications which might be expected to be a major factor in holding the tariqa as a whole together. Traditionally, texts and travel were the main cohesive force in the Sufi orders beyond the local situation. They continue to be a significant factor. The talks of Shaykh Nazim, usually recorded and transcribed by trusted murids, circulate widely and across national boundaries in print form, as do audio- and videotapes. The itinerancy of Shaykh Nazim visiting his various groups of followers is reciprocated by the regular visits to his home in northern Cyprus by individual murids. The majority of this travelling is between the centre (the Shaykh's home) and the periphery (the local groups), but some exchanging of visits does take place between local groups, particularly when Shaykh Nazim is visiting but also at other times.

The Internet has become a major new means of communication in this tariqa, as it has among many Islamic groups and movements. As we have seen in the case of the millennium debate, the Internet has become the means by which news and ideas have become able to move instantly around the network. However, it has not necessarily strengthened the coherence of the tariqa beyond the local - in fact, it could be argued to have created the opportunity for more 'locals' to be created. On the one hand, the Internet has excluded those who have no or only limited access to it. On the other 
hand, the ease of access to publishing on the Internet has enabled the proliferation of Haqqani sources. We have identified five websites in each of Britain and the USA and further ones in mainland Europe, as well as several electronic newsgroups and mailing lists. As a network with no centralized directive leadership, these are often the projects of dedicated individuals. They sometimes publish material and views which awaken the ire of other members of the tariqa who then publish counter-texts on other sites. The ease with which hackers can infiltrate confusing material into opponents' sites while disguising their true source further complicates the field. In effect, the source on the Internet becomes the equivalent of a local group with all the variations which that entails.

Two questions remain of key significance to this project, namely, what is it that enables us to talk of this very disparate network as a community with any kind of common character and cohesion, and in what ways is it 'transnational'? To the first question, our response is that the Haqqani tariqa is surprisingly traditional in Sufi terms. Traditionally, a Sufi tariqa existed primarily as a local group, adapting to and taking on the character of the locality in which it was integrated. Its recruitment, membership, public profile and activities reflected the local environment. What held it together with other local groups of the same tariqa were certain shared teachings and rites, an expectation of hospitality when travelling and, above all, adherence to the commonly acknowledged Shaykh and his spiritual inheritance and guidance. Those contemporary Sufi groups which function coherently under a centrally directive leadership are much more akin to certain Islamist political parties than they are to traditional Sufism. The traditional nature of the Haqqanis is evident both in the enormous local variety and in the central esteem in which Shaykh Nazim is held. Commenting on our research, one Italian murid told us: 'You will only find the complete story in Cyprus', and our Russian researcher visiting Dagestan after spending a week with Shaykh Nazim in Cyprus was effectively regarded as his representative after several years without contact. As we have observed around the visits of Shaykh Nazim to Britain and Lebanon, the tariqa only fully exists where Shaykh Nazim is.

The Haqqani tariqa clearly has a transnational presence. But unlike much of the current discussion around transnationalism, including the majority of the projects on the Transnational Communities Programme, ${ }^{16}$ this community is only very marginally constructed around migration. The movement of people around the network has been determined by the network rather than the movement, leading to its establishment in new localities. The network has clearly not expanded along migratory routes. This itinerancy of limited numbers of members is partly directed to the centre, i.e. Shaykh Nazim's base in Cyprus, and partly towards other local groups, this latter mostly in Europe and the USA. This mirrors the travels of Shaykh Nazim himself and, to a lesser extent, that of Shaykh Hisham. However, it also seems clear that at all normal times, i.e. when Shaykh Nazim is not visiting, it is the autonomy of the local group that is most characteristic of the tariqa. At the level of ideal construction, therefore, the tariqa is transnational, while at the level of existence in society it is local; the transnational usually only becomes 'real' in the presence of the Shaykh. 'Translocal' might be a more appropriate term. 


\section{Transnational Sufism}

\section{Notes}

1 This contribution represents an overview of the results of a project entitled 'Ethnicity, politics and transnational Islam: a study of an international Sufi order' funded by the Economic and Social Research Council between October 1998 and March 2001.

2 See A. Zelkina (2000), pp. 100-120; A. Shikhsaidov, Islam v Srednevekovom Dagestane, Makhachkala: DGU, p. 128.

3 See A. Kose (1994); T. Atay (1994); I. Draper (1985).

4 D. Habibis (1991), pp. 603-619.

5 For more on the history of the tariqa see the contribution by David Damrel elsewhere in this volume. Shaykh Hisham has produced a substantial volume on the Naqshbandi tariqa which might be termed the 'official' account of the Haqqanis (Muhammad Hisham Kabbani 1995). Other useful discussion is to be found in F. Meier (1994).

6 See J. S. Trimingham (1971).

7 'Abdallah Hama (1990), pp. 327-338.

8 A. Nizar Hamzeh and R. Hrair Dekmejian (1996).

9 www.aicp.org/Graphics/Qubrusi/Qindex.htm.

10 See M. Gammer (1994), pp. 39-45; N. Smirnov (1963).

11 D. Makarov (2000), p. 11.

12 G. Yemelianova (2001), p. 675.

13 Ibid. p. 674.

14 The text of the statement, presented at an open forum on 7 January, was published in an amended form on http://islamicsupremecouncil.org/Statement/islamic_extremism.htm. The Islamic Supreme Council of the US is primarily a Haqqani group presided over by Shaykh Hisham.

15 At a UNESCO conference in Tashkent, September 2000, attended by Nielsen, Sheikh Hisham took part as an official guest of the President of Uzbekistan.

16 The Transnational Communities Programme, funded by the Economic and Social Research Council and led by Dr Steven Vertovec, Oxford, ran from 1997 to 2002. More information is available at http://www.transcomm.ox.ac.uk/. 


\title{
6 Aspects of the Naqshbandi-Haqqani order in North America ${ }^{1}$
}

\author{
David W. Damrel
}

American Islamic mysticism is the product and project of two complementary forces in contemporary North American society and culture. One of these generative forces is the diverse vitality of the substantial multi-ethnic and multi-generational US and Canadian Muslim communities. A second powerful factor is a more general modern American interest in a broadly conceived 'spirituality' that investigates and sometimes incorporates religious beliefs, symbols and rituals from a dizzying host of sources, including Islam and Islamic mysticism. For many individuals pursuing this brand of integrative spirituality, Islamic mysticism, conveniently described by the term 'Sufism', does not require a Muslim identity. Understanding this interaction between Muslim and non-Muslim practitioners of mysticism in the Americas - is a crucial element in interpreting the shape and trajectory of Islamic mysticism in the Americas.

New World Islamic mysticism is practised by both Muslims and non-Muslims; it may transcend barriers of gender, generation, class and ethnicity or serve to reinforce them; it may be envisioned as inseparable from organized social interaction and expression, or imagined as a deeply private spiritual component of an individual's customized world-view. The proper study of the contours of Islamic mysticism in North America becomes an examination of a sprawling set of interdisciplinary questions, themes and concerns.

The social setting of most North American Islamic mysticism is within the stunningly diverse Muslim communities that make up the New World expression of the umma. Sufism in these communities is virtually synonymous with the semi-private practices of Sufi orders - the numerous and variously configured social organizations called 'brotherhoods'. Hierarchical lineages of spiritual masters, special sets of teachings and disciplines, and unique hagiographical traditions all serve to distinguish these brotherhoods from one another.

One of the most visible of these Sufi orders in the context of contemporary religious life in the Americas is the Naqshbandi-Haqqani order. This traditional Sufi brotherhood, with deep roots in the Muslim communities of the eastern Mediterranean, has established itself in the last decade particularly as one of the fastest-growing and most important orders in Western Europe and North America. The significant growth and spread of this conservative Islamic spiritual movement in largely non-Muslim contexts suggests much about the dynamics of Sufism in the Americas. This contribution 


\section{Aspects of the Naqshbandi-Haqqani order in North America}

will survey the history and present status of the order in the United States and Canada before specifically examining two spheres of Haqqani activity: first, the outer, public activities of the brotherhood and second, some of the inner themes of religious and mystical instruction found in Haqqani publications. The Haqqani shaykbs choose to illustrate their traditional Sufi spiritual themes through examples drawn from contemporary Western non-Muslim experience. In this way, current events - such as Y2K excitement, hoof-and-mouth disease, and the death of Princess Diana - all become part of mystical pedagogical technique. The headlines and the way the Haqqani shaykhs interpret them for their disciples become living lessons that can speak powerfully to such themes as morality, life after death, and the cultivation of an inner life.

\section{History of the order}

The Naqshbandi-Haqqani order is a modern branch of the well-known Naqshbandi order, a Sufi brotherhood that took shape under the guidance and teachings of the Central Asian shaykh Khawaja Baha' al-din Naqshband (d. 1389 in Bukhara) but tracing its ultimate origins to the Prophet Muhammad (d. 632 in Medina). ${ }^{2}$ The Naqshbandis are widespread throughout the Muslim world and are active today especially in Turkey, Syria, Lebanon, the Balkans, South and Central Asia, Malaysia and Indonesia. A set of key features defines the Naqshbandis across these diverse ethnic, social and historic settings. These include: (1) an uncompromising Sunni orientation, (2) emphasis on shari'a and Sunna, (3) a tradition of full social and political engagement with the world, and (4) as noted by K. A. Nizami, a willingness to guide and if necessary confront the state in order to bring it closer to religion. ${ }^{3}$

Shaykh Nazim Adil al-Qibrusi al-Haqqani al-Naqshbandi (b. 1922) is the 'grandshaykb' and namesake of the present Naqshbandi-Haqqani lineage. Born in Larnaca and raised in the family of a junior Egyptian colonial administrator in the British crown colony of Cyprus, Shaykh Nazim's spiritual education began in Istanbul. After receiving mystical instruction from a number of shaykhs, he travelled to Damascus where he took initiation into the Naqshbandi order from Shaykh 'Abd Allah Daghestani (d. 1973) in 1945. When his spiritual mentor ordered him back to Cyprus, Shaykh Nazim personally 'spread spiritual guidance and Islamic teachings' on the island for the next seven years, despite official Turkish government opposition to his activities and threatened legal actions against him. ${ }^{4}$

In 1952, Shaykh Nazim married into the family of one of Shaykh Daghestani's senior disciples and relocated to Damascus. From Syria Shaykh Nazim continued to visit Cyprus regularly and made extended trips to Lebanon, Egypt and Jordan. ${ }^{5}$ Naqshbandi-Haqqani hagiographical literature portrays this period, from the early 1950s until 1974, as a time of intense spiritual activity for Shaykh Nazim, marked by visionary retreats and extensive walking tours through Syria, Cyprus, Jordan and Turkey. In these preaching tours, he encouraged people 'to leave atheism, secularism and materialism and to come back to God'. ${ }^{6}$ At the time of Cypriot independence from Great Britain in 1960, Shaykh Nazim emerged as a vocal opponent of the secular coalition government headed by president Archbishop Makarios (d. 1977) and 
vice-president Dr Fazil Küçük. The Cypriot press attacked Shaykh Nazim and denounced him as an anti-reformist and reactionary agent of foreign interests. It was even suggested that he was a follower of the Baha'i faith. Shaykh Nazim's critiques continued unchecked, and the Turkish Cypriot administration expelled him in 1965. ${ }^{7}$ By most accounts Shaykh Nazim returned to Syria and Lebanon, where he continued his preaching and his rigorous mystical discipline.

Shaykh Nazim's pir Shaykh Daghestani died in 1973, and that same year Shaykh Nazim received permission 'from the Prophet (Muhammad) to spread the light of Islam into the European countries'. ${ }^{8}$ He travelled to London in 1974 and, warmly welcomed by followers of Gurdjieff protégé John G. Bennett (d. 1974), established a centre there. Starting that same year, Shaykh Nazim established an annual regular travel routine, spending each Ramadan in London before returning to Turkey overland and visiting various Muslim and non-Muslim European communities en route. Over the next two decades he continually expanded his proselytizing mission beyond Europe to include South and Southeast Asia; by the late 1980s he claimed to have followers all over Asia, including 'thousands' in Pakistan and over 20,000 disciples in Sri Lanka alone. He also retained his deep-rooted ties to prominent families in Lebanon, notably the Kabbani family in Tripoli. ${ }^{9}$ Shaykh Nazim further cultivated personal relationships with various political figures who were sympathetic to his teachings and willing to help fund the activities of the order. ${ }^{10}$

From 1973 on it is appropriate to recognize Shaykh Nazim al-Haqqani's branch of the order as the Naqshbandi-Haqqani, to distinguish it from other branches within the Naqshbandi brotherhood. This name change has historical precedents within the order as earlier branches typically identified themselves after their shaykhs, e.g. the Naqshbandi-Mujaddidi (after Shaykh Ahmad Sirhindi, 'the Mujaddid', d. 1624) and the Naqshbandi-Khalidi (after Maulana Khalid al-Baghdadi, d. 1827). It is important to note this division within the order and to be clear that Naqshbandi-Haqqani teachings and practice represent Shaykh Nazim's sub-branch alone. ${ }^{11}$

The leader of the Naqshbandi-Haqqani order in the Americas is Shaykh Muhammad Hisham Kabbani, Shaykh Nazim's khalifa (spiritual representative) and son-in-law. Modern Haqqani sources explain the introduction of the order into the Americas as part of Shaykh Nazim's insight into the religious needs of the West. To quote:

Foreseeing the great spiritual hunger of people in the Western Hemisphere, Shaykh Nazim assigned his representative and deputy, Shaykh Muhammad Hisham Kabbani of Lebanon, to reside and teach Islam and the mystical Naqshbandi-Haqqani Sufi path in North and South America. ${ }^{12}$

Shaykh Hisham, accompanied by his wife and children, relocated to the United States in 1990 and the family received their green cards in 1991. ${ }^{13}$ Again, Naqshbandi sources describe miraculous early success for the order. At first Shaykh Hisham struggled 'alone, unsupported', but within a very short time:

the Shaykh was blessed by Allah to bring into the fold of Islam over 20,000 educated, Caucasian Americans from the middle and upper classes. Under his 


\section{Aspects of the Naqshbandi-Haqqani order in North America}

direction and guidance, these new Muslims formed the basis for a new approach to teaching Islam in America, one that quickly overshadowed that of the immigrant and earlier Muslims who stressed the more extremist doctrines in Islam. ${ }^{14}$

Shaykh Nazim made his first visit to his khalifa in the United States and Canada in 1991, returned in 1993, and remains a regular visitor to North America. Haqqani literature says that as a direct result of Shaykh Nazim's first visits over 10,000 people in North America converted to Islam and took initiation in the Naqshbandi Order. ${ }^{15}$

Today, after just a decade of work, Shaykh Hisham oversees a network of twenty-three mosques, centres and retreats, anchored by a convention and retreat centre on farmland in Fenton, Michigan. He travels almost constantly from centre to centre and abroad, and frequently accompanies his pir, Shaykh Nazim, in his travels. In addition, the order maintains a significant presence on the World Wide Web through a number of related and sophisticated sites. These sites offer archived subbat (edifying conversations on spiritual topics), the travel schedules of the shaykhs, audio and video records of various events, and online shopping.

There are no firm numbers on the strength of the Haqqani following in North America. Publications for the Islamic Supreme Council of America (ISCA), one of the organizations established by Shaykh Hisham, report that 'Grandshaykh' Nazim is responsible for the 'spiritual well-being of over 2 million followers around the world'. Shaykh Hisham is reported to have brought over 60,000 Americans to Islam. In addition, the order reports that Shaykh Hisham has led over 20,000 Muslim immigrants to America to embrace Naqshbandi teachings. ${ }^{16}$ Haqqani membership numbers are almost certainly inflated - in one published interview Shaykh Hisham suggested that he had 30,000 followers, but determined efforts by investigative journalist Teresa Watanabe could only confirm a few thousand members. ${ }^{17}$

The programme and activities of the Haqqani order in the Americas can be considered in two sections. The first emphasizes the institutional, social side of the order in short, the public face of the movement. The second considers the teachings of the order and how they are presented to a modern American audience.

\section{Outer spheres of activity: public agenda and status}

The Haqqani order expresses a public agenda in the Americas in a number of places: it is simply to promote Islam. ${ }^{18}$ To this end, the order has created several affiliated organizations, each dedicated to particular types of da'wa-related activities. The major institutional elements of what Annabelle Bottcher describes as an ambitious 'Sufi religious enterprise' include four non-profit organizations, all headed by Shaykh Hisham. The first is the order itself, officially designated as the Haqqani Sufi Foundation. Then follow: (2) the As-Sunna Foundation of America (ASFA); (3) Kamilat Muslim Women's Organization; and (4) the Islamic Supreme Council of America (ISCA). ${ }^{19}$ The latter three organizations are responsible for most of the public activities of the order.

The As-Sunna Foundation of America (ASFA) emphasizes religious education among Muslims and publishes general works that champion the four major Sunni 
law schools. ASFA insists that the regrettable controversies that divide American Muslims are the consequences of a basic Muslim ignorance about Islamic 'revealed law'. The foundation then works to correct this ignorance and presents itself as an authoritative, legally sound guide to proper practice. ASFA lays claim to credibility based partly on affiliations with a number of internationally known Islamic institutions of higher learning, including al-Azhar. Headed by Shaykh Hisham, ASFA also chooses to emphasize the shaykh's credentials as a legal scholar - a master of Hanafi law - over his mystical training and position.

Kamilat Muslim Women's Organization, founded in 1997, is dedicated expressly to 'quality of life' issues faced by Muslim women in the United States and Canada. The organization, which has opened a lobbyist's office in Washington, addresses a range of domestic issues pertaining to family, health, education and marriage. It also organizes charity work connected with emergency relief efforts and aid for Muslim refugees who have relocated to the USA. Kamilat has launched several initiatives to raise Muslim awareness of certain issues, including breast cancer risks and domestic violence, and cooperates with a variety of like-minded secular organizations. The organization offers cultural sensitivity training to interested groups and encourages volunteerism among Muslim women, ranging from in-home health visits to English instruction for recently arrived Muslim immigrants. The group identifies forty distinct Muslim cultures among the American Muslim community. ${ }^{20}$

The Islamic Supreme Council of America (ISCA) is by far the most visible, politically active and controversial of all the affiliated Haqqani organizations. The ISCA established an office in Washington, D.C. and publicly committed itself to two goals. The first is to serve the cause of Islam as a resource for Muslim groups and individuals seeking advice on issues of law - shari' $a$ - that arise 'as Islamic traditions come into contact with American culture'. The group emphasizes practical and authoritative solutions for American Muslims seeking to maintain 'Islamic beliefs in a modern secular society'. Implicit in this mission is the conviction that American Muslims - both immigrant and convert - have lost sight of a proper Islamic lifestyle and require such guidance. In this way, the order portrays itself as the upholder of legitimate, shari ${ }^{\prime}$ and Sunna-based practice. The focus here is on American Muslim communities.

The second goal centres on non-Muslim America. The ISCA mission statement declares 'we intend to work closely and proactively with non-Muslim individuals and organizations to present Islam as a religion of moderation, tolerance, peace and justice'. The ICSA later on commits to 'strengthening the values of charity, family love, education and public responsibility in American life'. ${ }^{21}$ In pursuit of these goals, the order has attempted to claim for itself a public role as a legitimate and representative voice of American Muslim sentiment and leadership. Shaykh Hisham, for example, has participated in a number of high-profile national political events, including a reception at the Clinton White House and speaking at a State Department Open Forum on Islamic 'extremism'. Other activities in the 'American public square' included a role in the successful US Muslim campaigns to increase the number of Muslim chaplains in the US military and encourage the postal service to issue a commemorative Ramadan stamp. The ISCA has struggled to position itself as a voice of 'traditional' Sunni Islam in the United States, with two key points on the agenda: 


\section{Aspects of the Naqshbandi-Haqqani order in North America}

first, to focus on service to the American Muslim communities; and second, to educate the American public in a corrective vision of what Islam is.

As noted earlier, the implicit Haqqani reading of North American Islam portrays a community marred by disarray, confusion and disunity. Simple ignorance about Islam is one of the causes of this anarchy, and the order seeks to remedy this through 'spreading the message of true Islam ... through all forms of print publication, video, television, radio, Internet and the latest forms of communication'. ${ }^{22}$ However, the order sees a far more serious obstacle to the progress of Islam in America. This is the influence of 'Salafi' Islam and Wahhabi-inspired attitudes and practices that, in the Haqqani view, mislead certain American - mostly immigrant - Muslims and at the same time greatly damage the image of Islam among non-Muslim Americans. More ominously, not only have the 'Salafis' and 'Wahhabis' misdirected the American Muslim community, they have embarked on a vicious and subtle campaign of slander against the order and Shaykh Hisham. ${ }^{23}$

The Haqqani response, beginning almost from the earliest appearance of the order in North America, has been an unyielding public anti-Wahhabi polemic, accompanied by a staunch shari $a$-based defence of Sufi practice. Shaykh Hisham himself has written refutations of Salafi positions, and the As-Sunnah Foundation publications catalogue is heavy with titles offering vigorous classical defences of Sufi concepts and practices such as ziyarat and intercession and allegiance to a shaykh. The Haqqani websites regularly report and condemn what they describe as international Wahhabi excesses and extremism in Afghanistan, Saudi Arabia and the former Yugoslavia.

In 1999, Shaykh Hisham ignited public controversy when he told a State Department Open Forum that 'extremism has been spread to $80 \%$ of the Muslims in the US' and that the overwhelming majority of mosques in America were 'being run by extremist ideologies'. ${ }^{24}$ He added that these extremist ideologies were spread on US campuses by 'clubs being put around the universities'. In this context, Shaykh Hisham identified 'extremism' with intolerance and militancy; in other Haqqani literature the terms 'extremists' and 'radicals' usually describe anti-Sufi groups as well as politically engaged Islamist groups. For Shaykh Hisham, the critical marker of Islamic extremism is both anti-Sufi rhetoric and political motivation.

Shaykh Hisham's flat declaration that extremism affected $80 \%$ of American Muslims astonished and angered the leadership of the most important American Muslim organizations. Within weeks the American Muslim Alliance, the American Muslim Council, the Islamic Circle of North America, the Islamic Society of North America, the Muslim Students Association and other leading groups issued a joint press release that vigorously attacked Shaykh Hisham's comments. They demanded an apology and accused Shaykh Hisham of ' $[$ in effect $]$ telling government officials that the majority of American Muslims pose a danger to our society'. ${ }^{25}$ Later, these same groups began a boycott of Haqqani activities and denied Haqqani participation in their activities. In other online forums, these groups labelled the Haqqanis as 'goofy Sufis' or 'Muslim hippies' and even 'a Muslim cult' that, among other serious errors, worshipped the dead and claimed divinity for their shaykhs. Some groups politicized the debate, and insisted that Shaykh Hisham is a Zionist agent, while leaders on both sides - the Haqqanis and their critics have claimed to be the targets of death threats. ${ }^{26}$ 
The positions on both sides have changed little since the State Department forum, and the Haqqanis today stand apart from the other established public organizations representing Muslim interests in the Americas. They still pursue a public agenda, but now mostly on their own and in isolation from initiatives by other American Muslim organizations. It seems likely that this estrangement diverted Haqqani focus from immigrant Muslim communities and led the order instead to devote more attention to missionizing activities in non-Muslim American society.

\section{Inner spheres of activity: themes of religious instruction}

Haqqani teachings in North America include a full range of Islamic mystical instruction and technique. In this context, three main points stand out. These are in no way exhaustive of the complete range of the order's presence in North America, but rather are examples chosen to reflect some of the tone of Haqqani activities.

The first point to address is the order's extensive use of the Internet in religious instruction. The important questions centring around the impact of new, personalized and interactive technology on an individual's religious experience and expression are still being formulated, much less answered. Nor is this a phenomenon limited to a particular faith community: the proliferation of web-based resources, organizations and individual opinion sites is challenging our conceptions of how to interpret religions, spirituality and their social configurations. The Haqqani order is one group that has wholeheartedly embraced this new opportunity.

Many of the presumed advantages of a virtual religious community are well known. It has been suggested, for instance, that isolated, geographically separated individuals can share a common online experience that provides a sense of religious community that would otherwise be absent. Smaller, often dissenting communities can thrive in the virtual equality of cyberspace. Both of these observations apply to the Haqqani web-based project. Visitors who hit the several Haqqani-affiliated sites find biographies of leading Naqshbandi shaykhs, a history of the order, a précis of Ottoman history, a guide to performing bay'at online and the touring schedule of Shaykhs Nazim and Hisham. There are 'live' prayers and sermons streamed from the site during Ramadan and during Maulid al-Nabi that allow anyone who is interested to be part of the process. In this manner, the presence of the shaykh is amplified in new and powerful ways. Those familiar with Arthur F. Buehler's recent discussion of three traditional types of Sufi shaykhs - an historical progression from teachingshaykhs to directing-shaykhs and then to mediating-shaykhs - may consider adding a fourth: the virtual-shaykh. ${ }^{27}$

The Haqqani investment in this form of media and technology also suits their chosen target audience. Note that the American Haqqani group describes their success in attracting a following among 'educated, Caucasian Americans from the middle and upper classes': statistically, this is precisely the demographic most likely to have the means and expertise to regularly explore the World Wide Web.

A second theme that runs through much Haqqani teaching of nearly the last three decades relates to the idea of millennialism. ${ }^{28}$ The order's consistent interest in the end of this world, the Mabdi, and the 'Signs of the Hour' is exceptional among Sunni 


\section{Aspects of the Naqshbandi-Haqqani order in North America}

mystical orders and has been noted by a number of scholars. In the context of North America and Western Europe, the order has been able to unite traditional Sunni ideas of the 'Last Day' with the millennial expectations of a new generation of European and American converts to Islam. The now largely forgotten anxiety that accompanied the advent of the year 2000 spoke volumes about a profound if unarticulated apprehension about the future that resonated powerfully with certain modern Western audiences, whether Christian, Muslim or avowedly non-religious. The Haqqani shaykhs were able to speak directly to some of these concerns from an Islamic perspective. Millennialism remains a signature theme for the order in North America.

The Haqqani shaykhs, privileged by their mystical attainments and status, profess deep understanding of the imminent 'Last days'. The Qur'an's compelling promises of devastating global anarchy (the 'Signs of the Hour') combined with a wealth of related Prophetic traditions inform well-established Sunni and Shi'i eschatologies. Cataclysmic events in the natural world and the stunning moral failure of human societies announce the 'Last Day', which brings on the end of 'this world' and inevitably climaxes in the physical resurrection and ultimate judgement of all human beings.

There is no consensus among Muslim scholars on the complex details of this apocalyptic script. The events, their order and the precise roles played by such figures as 'Isa (Jesus) and the Mabdi ('the rightly guided one') and Dajjal (the 'deceiver') have been discussed and imagined for centuries by Muslim thinkers from an astounding range of backgrounds and traditions.

The Haqqani shaykhs admit no confusion about the proper understanding and timing of the Sunni sources; for them, the Dajjal and the Mabdi are both alive now, apocalyptic global conflict is imminent, and the fate of this world is sealed. The leading players in this finale are already in the theatre: as Shaykh Hisham assured his listeners in 1992, 'we are the only group expecting Mahdi and Jesus' coming very soon. We are on the right track. We have met them.' The Haqqani shaykhs maintain a visionary spiritual connection with the two figures. 'What I am telling you is according to true vision, not fake or imagined. Mahdi(s) and Jesus(s) are among you. ${ }^{29}$

New Muslim communities in Europe and the Americas will play important roles in the complicated 'Last Days' agenda described by the Haqqani shaykhs. The well-known Islamic apocalyptic tradition that calls for the sun to rise in the West at the end of the world is interpreted to refer specifically to these new convert communities. ${ }^{30}$ In this scenario, hidden saints will operate in Germany and China, and Islam will spread in ways unprecedented in history - England will peaceably convert to Islam. A brief period of world peace marked by US hegemony will end when World War III - incited by Dajjal erupts and takes billions of lives. At the climax of these terrifying events, Mabdi and 'Isa will slay Dajjal and fashion a global reign of justice and peace. Soon after, time and the world will cease with the coming of the final judgement.

The Mahdi, presently biding his time in a cave in the 'Empty Quarter' in Saudi Arabia, has commanded Shaykh Nazim to ready his 'helpers'- the Muslims and nonMuslims who will rally behind the 'rightly guided one' when he declares his redemptive mission. ${ }^{31}$ Shaykh Nazim and Shaykh Hisham occasionally reveal some of their mystical foreknowledge of coming events, but insist that they speak only when the Mabdi grants them permission. 
This real-time Naqshbandi-Haqqani mystical exegesis of world events reads as a diverse catalogue of Islamic and non-Islamic apocalyptic themes and imagery. The shaykhs speak to their followers in Europe and North America of 'Armageddon' and 'World War III', the 'Anti-Christ' and the 'Saviour'. They count down the end of the world by a Gregorian (and not a Hijri) calendar, and have offered (and revised) starting dates for the 'Last Days' in 1987, 1989, 1991, 1993 and 2000.

It is significant that Shaykh Nazim, on his tour of Sri Lanka in May 2001, visited the celebrated science-fiction author Arthur C. Clarke. Clarke, of course, author of the novel 2001: A Space Odyssey and other works, might seem an unusual choice as a spiritual figure to call on in South Asia. However, for a global Haqqani clientele following the meeting via the World Wide Web, the audience brought together familiar themes of spirituality, interest in the future, technology, humanism and modern Western culture in a neat if sometimes incongruous package. ${ }^{32}$

These discussions of diverse secular and spiritual 'Last Day' images allow the shaykhs to introduce certain subtle mystical themes. Speculation about the fate of the world and of the individual becomes a natural entrée for deeper spiritual lessons about the after-life, mystical praxis and Islam. The Haqqanis can effectively transform such modern tropes of 'Western' spirituality as religious disenchantment, interest in prophesy, and millennial anxiety about the 'next world' into Islamic dialogues concerned with behaviour in this world.

This introduces a third point about Haqqani teachings in the Americas: the ongoing effort to make the affairs of the modern world into spiritual teaching tools. This ability to extract religious and spiritual meaning from contemporary events or concerns for the benefit of murids is, of course, an age-old practice. In the unfolding context of the 'Information Age', the Haqqani shaykhs offer a real-time mystical commentary on world events. Two brief examples suffice.

In March 2001, Shaykh Nazim issued a press release that called on European elected leaders and religious leadership to impose a moratorium on the slaughter of livestock in connection with the hoof-and-mouth disease epidemic. He argued that the mass destruction of millions of animals, most of which were not infected, was contrary to the idea of mercy found at the core of all religions. In his statement, he called for the use of vaccination as an alternative and, short of that, the distribution of any meat from the animals to the 'millions of hungry people in the world'. The press release emphasized over and over again Islam was a religion of peace and compassion. ${ }^{33}$ This public declaration painted the shaykh and the order as champions of an engaged and humane Islam that was intimately connected with contemporary society. Although originally intended for a European audience, the message was widely available among the Haqqani community in North America.

A second example of spiritual pedagogy also demonstrates how the Haqqani leaders employ current events to launch deeper discussions of proper behaviour and conduct. Speaking in the fall of 1997, shortly after the tragic death of Diana, Princess of Wales, Shaykh Nazim commented on the event and its aftermath to a circle of his followers in Britain. In his extended and wide-ranging comments, he reflected on life and death in general and on her life in particular. Her early death, he declared, was a 'Heavenly Warning', bristling with lessons for everyone, Muslim and non-Muslim. 


\section{Aspects of the Naqshbandi-Haqqani order in North America}

He explained that Britons were struggling to cope with her death because most were no longer connected to any religion and so had no guidelines to offer help in the present situation. Islam offered such guidelines, he insisted, that help the individual understand death and prepare for it. In a striking offhand analysis recorded and transcribed by one his murids, Shaykh Nazim listed three actions - all part of traditional Islamic behaviour - that he insisted would have saved Diana's life. First, he explained that the Princess should have followed Islamic rules of modest dress. If she had dressed modestly, the paparazzi would not have been interested in photographing her. There would have no pursuit, and the fatal accident would not have happened. Second, the shaykh explained that she and her party should have avoided alcohol specifically, wine. Finally, according to Shaykh Nazim, the Princess violated the rules governing contact between men and women who are not married to one another. ${ }^{34}$ The remainder of the session became a mystical exploration of attitudes toward death in Islam, and the constant need to be prepared to face unexpected death. When Shaykh Nazim seized the opportunity to stress comportment and behaviour during the vivid outpouring of emotion following Princess Diana's death, he was simply continuing a centuries-old tradition of instructional techniques rooted deep in the practice of the Naqshbandis and other Sufi brotherhoods.

\section{Trajectories}

This preliminary sketch of the Naqshbandi-Haqqani in North America has emphasized several points. First, that in just over ten years in North America, the order has succeeded in establishing a considerable convert following. These followers come mostly - but not solely - from non-immigrant American Muslims, that is to say recent converts to Islam. Much of the order's infrastructure - especially its commitment to web-based technology and relatively high public status for women - reflects this social foundation. Remarkably, the order represents one of the liveliest and most self-conscious North American Muslim organizations to focus on converting Americans (particularly those of European heritage) to Islam. The order has made a significant effort to promote Islam and specifically Sufism in ways meant to appeal to broader elements of non-Muslim American society. Haqqani critiques of consumerism and environmental degradation, ecumenical approaches to other religious traditions, at least superficial interest in certain New Age groups and an apocalyptic explanatory model to account for a globe seemingly besieged by new and constant impending disasters - all these tap a rich vein of contemporary spiritual interests that can foster interest in the order. There is no reason to expect that interest in the order and its ideas will diminish in the near future.

At the same time, the order's effort to position itself as an authoritative public representative of 'mainstream' American Islam has been much less successful. In the last two years the order increasingly has become alienated from other American Muslim associations and this distance does not seem likely to decrease. What emerges from this estrangement is the distinct possibility of adding another permanent community to an already complex American Muslim social flora - a largely convert, mystically inclined, middle-class and educated community drawn from elements of American society that traditionally have been among the slowest to embrace Islam. 
While general interest in the Haqqani order seems stable for the time being, there are certain long-term questions. Particularly, the issue of authority within the order itself deserves consideration. Although there is no question that Shaykhs Hisham and Nazim exert full leadership over the apparatus of the order, on occasion news of dissent becomes public. Several times in recent years, the order has warned its far-flung followers against certain false itinerant shaykhs who claimed to represent (and collect money) for Shaykh Nazim when they were not authorized to do so. In other cases, well-intentioned and independent murids record, transcribe and publish the conversations of the shaykhs without their permission. These unedited, unauthorized accounts of the order's teachings are sometimes sources of embarrassment to the order.

These persistent internal challenges are overshadowed by a larger, institutional issue faced by almost every mystical order - the traditional Sufi emphasis on the primacy of the shaykh over the primacy of the brotherhood itself. Generally speaking, the loyalty of a murid is to their murshid rather than to the institution of their brotherhood. While the living presence of Shaykhs Nazim and Hisham forestalls this issue, the shape the order will take after them becomes an important question. In an American social context in which religious authority is consistently challenged, reformed and reshaped, it remains to be seen if the Naqshbandi-Haqqani can retain their structure and coherence in the long term.

\section{Notes}

1 A research grant from the American Academy of Religion was invaluable in pursuing this research. I gratefully acknowledge the academy's support here.

2 Aspects of the rich and complex history of the Naqshbandi order have been treated by many authors, but Hamid Algar stands alone as the foremost historian and interpreter of the brotherhood; see Hamid Algar, (1975, 1976). The late Khaliq Ahmad Nizami also contributed an important survey of the order; see K. A. Nizami, (1991).

3 Nizami (1991), p. 163.

4 Shaykh Muhammad Hisham Kabbani, (1995), p. 383. All complaints against him were miraculously dismissed, according to his hagiographer.

5 Kabbani (1995), p. 385.

6 Kabbani (1995), p. 385.

7 See David Nicolson Freidberg's useful thesis (1994), p. 32, citing a pamphlet by Shaykh Muhammad Hisham Kabbani, About Our Master Sheikh Nazim Effendi, n.p., n.d.

8 Freidberg (1994), p. 32. Before this, Shaykh Nazim apparently had not been allowed to teach about the order in Europe.

9 Annabelle Bottcher, (2000), 'The Naqshbandiyya in the United States', published online at http://www.naqshbandi.org.

10 Kabbani (1995), p. 396, asserts that Shaykh Nazim was the shaykb of the late prime minister and president of Turkey, Turgut özal (d. 1993) and has personal influence with such figures as Sultan Hajji Hasan al-Bolkiah Mu'izz al-din Waddaulah (the Sultan of Brunei) and the Malaysian prince Raja Ashman Azlan. He also is said to have had close though recently cool connections with the leader of Turkish Cyprus, Rauf Denktash; see Hamid Algar, (1991b), p. 148.

11 Shaykh Nazim's own pir, Shaykh Daghestani, belonged to the Naqshbandi-Khalidi branch. For a hint of the diversity within the modern branches of the Naqshbandi order, see Hamid Algar, (1991a), pp. 41-44. Note too, Algar's dismissal of the Haqqani group as 'somewhat eccentric'; see Algar (1991b), p. 148. 


\section{Aspects of the Naqshbandi-Haqqani order in North America}

12 Naqshbandi America, Islamic Supreme Council of America website, http://www. islamicsupremecouncil.org/Spirituality/Naqshbandi/naqshbandi_america.htm.

13 Bottcher (2000), p. 6.

14 Naqshbandi America, Islamic Supreme Council of America website, http://www. islamicsupremecouncil.org/Spirituality/Naqshbandi/naqshbandi_america.htm.

15 Kabbani (1995), p. 396.

16 Naqshbandi America, Islamic Supreme Council of America website, http://www. islamicsupremecouncil.org/Spirituality/Naqshbandi/naqshbandi_america.htm.

17 Watanabe, Teresa (1999).

18 Naqshbandi America, Islamic Supreme Council of America website, http://www. islamicsupremecouncil.org/Spirituality/Naqshbandi/naqshbandi_america.htm.

19 Bottcher (2000), p. 6.

20 This sketch is based on the organization's self-description, available at http://www. kamilat.org/fr_about.htm.

21 See the Islamic Supreme Council of America website available at: http://www. islamicsupremecouncil.org/mission.htm.

22 Naqshbandi America, Islamic Supreme Council of America website, http://www. islamicsupremecouncil.org/Spirituality/Naqshbandi/naqshbandi_america.htm.

23 Islamic Supreme Council of America (1999), 'An Open Letter to All Muslims', online at: http://www.islamicsupremecouncil.org/condemnation/ISCA_official_response.html.

24 Richard H. Curtis, (1999).

25 Muslim Student Association news site, 'Subject: Kabbani Affair: Comments on Sheikh Kabbani's Open Letter and Responses' at: http://msanews.mynet.net/MSANEWS/20000622. 5.html.

26 See the Muslim Student Association news site, 'Subject: Kabbani Affair: Comments on Sheikh Kabbani's Open Letter and Responses' at: http://msanews.mynet.net/MSANEWS/ 20000622.5.html.

27 Arthur F. Buehler, (1998).

28 Michael Barkun offers a useful cross-cultural definition of millennialism as 'those instances when human beings band together and actually act upon a belief in imminent and total transformation'. See Michael Barkun, (1974), p. 2. For a general comparison with earlier understandings of millennialism, note Norman Cohn's familiar, salvation-centred definition that requires a millenarian movement envision salvation as collective, terrestrial, imminent, total and miraculous; see Cohn, Norman (1970), p. 13.

29 Kabbani, Shaykh Muhammad Hisham (1993), p. 10. I am grateful for Mr Mateen Siddiqui's help in interpreting this passage.

30 Freidberg (1994), pp. 81-82.

31 Shaykh Muhammad Nazim Adil al-Haqqani an-Naqshbandi, (1994), pp. 125-129.

32 An account of this meeting titled 'Space: the Final Frontier' is online at: http://www. islamicsupremecouncil.org/CountryReports/World_Tour_2001/SriLanka/may19/default.htm.

33 Press release issued March 29, 2001 in Lefke, Cyprus, by the Haqqani Sufi Foundation.

34 Shaykh Nazim al-Haqqani, (1997), pp. 27-32. 


\title{
7 Seekers on the path Different ways of being a Sufi in Britain
}

\author{
Pnina Werbner
}

\section{Organizational patterns of Sufi cult expansion}

From its early beginnings, mystical Islam respected no national or international boundaries. Sufis moved along the trade routes and paths of imperial conquest and religious pilgrimage to remote and widely scattered corners of the earth. They began their itinerant existence in the tenth century $\mathrm{CE}$, and have carried the message of Islam from the Near East to South Asia, Indonesia and West Africa. ${ }^{1}$

Officially, Sufis claim to belong to named tariqa orders or fraternities, but none of these orders have inclusive command structures. What they share, notionally, are ways or paths towards Allah; wazifas, secret formulas and sequences of prayers for disciples to follow. These lead them through the different 'stations' on the mystical journey towards experiential revelation. In practice, Sufi cults focus around living or dead saints as ta'ifas, regional cults, organized very much along the same lines as other such regional cults. ${ }^{2}$ Each cult has a sacred centre, the lodge founded by a living saint, and branches that recognize affiliation to it and participate regularly in its annual festivals. These branches extend across national boundaries wherever the emissaries of a saint, his khalifas and disciples, happen to settle. The foundation of a branch follows a predictable pattern and as it develops its material aspects (in the form of a mosque, for example) and ritual practice are enhanced. A branch may start with little more than a group which meets regularly to perform $d h i k r$, the rhythmical chanting in unison of the name of Allah. It may progress to holding monthly gyarvi sharif ritual meetings in which sacralized food is cooked and distributed in commemoration of the birth/ death of 'Abd al-Qadir al-Jilani, one of the founding saints of South Asian Sufism. It may gain its own khalifa, vicegerent or deputy, recognized by the Centre (or miraculously, by God). It may even distribute langar (sacralized food, freely offered) on a daily, weekly, monthly or annual basis. ${ }^{3}$

Sufi regional cults are not particularly exclusive, although this varies somewhat. Disciples may follow more than one saint, attend more than one annual 'urs festival in commemoration of a departed saint, and in the absence of disciples' 'own' saint to whom they have sworn allegiance - happily attend the festivals of another saint, even from a different Sufi order. At the same time, however, Sufi regional cults are locked in thinly disguised competition with each other for disciples, and having many disciples, an enormous gathering at saintly festivals, certainly proves that a saint is a 


\section{Seekers on the path}

great saint, a wali, friend of God. Like other regional cults, Sufi cults wax and wane, with the sacred centre of the cult rising to great prominence or sinking into oblivion. ${ }^{4}$ Characteristically, during the period of cult expansion, new branches are formed which leapfrog over the sacred dominions of other, established Sufi cults, and over political and administrative boundaries, to form a new sacred network focused on the central lodge where a living saint lives or is buried.

Within South Asia, there are the recognized cults of the great Sufi saints who brought Islam to the subcontinent, whose places of burial draw millions annually. But there is no obligation to perform pilgrimage to these places. A minor saint in the back street of a dilapidated part of a slum in a large city may draw devotion from a circle of local disciples. ${ }^{5}$ Sufism is thus extremely chaordic, ${ }^{6}$ having the capacity to expand across boundaries while remaining local and even parochial, recognizing its regional, national and international extensions while practising locally.

Post-colonial transnational Sufi cults outside Pakistan or India form one materially embodied way of being diasporic. Saints, disciples and followers move in predictable pathways between major and minor sacred centres, in the diaspora or between it and Pakistan, especially on festival occasions. South Asian Sufi regional cults are located ‘in' a global South Asian Muslim diaspora rather than being simply 'diasporic'. The discourses and practices they perpetuate are a way of living and seeing things outside home, and the movements of Sufi cults in space, like their material exchanges across space, constitute one dimension (modality, perspective) of the Pakistani global diaspora today, and, even more broadly, of the Muslim global diaspora.

In Britain there are by now a large number of Pakistani Sufi cults centred on local khalifas or saints (pirs) which recognize sacred genealogical links to different orders and saints located in different parts of Pakistan. Each cult forms a network of saintly brothers and sisters (pir-bhailbben) with centres or branches in a dozen British cities: Bradford, Manchester, Birmingham, Luton, London, and so forth. In my recent research on such orders, I studied members of six very different orders, all located in Manchester, each with a local leader and an extensive national and international network. Disciples and saints visit each other's centres in other cities regularly on a weekly or monthly basis, and keep in regular contact with the cult centre in Pakistan. Reciprocally, saintly leaders of the cults from Pakistan visit their followers in Britain, often staying for several weeks or months.

In the present chapter I want to focus on the life paths and ways of being a Sufi of several khalifa belonging to a single Sufi order and regional cult of a Naqshbandi Shaykh, Zindapir, who died in 1999 in the North West Frontier Province at the age of about 89. Zindapir was a classic directing shaykh in the Naqshbandi style. ${ }^{7}$ Both amongst his closest khalifas in Pakistan, and those who migrated to Britain, the tendency was to emulate the saint as the supreme example of ethical living. So much so that in Pakistan itself the lodges of khalifas, their appearance and mode of living replicated the sacred centre through a process of remarkable religious mimesis. At the same time, as I argue in my book about Zindapir's cult, ${ }^{8}$ each khalifa also followed a distinctive path towards Allah.

As mentioned, the Naqshbandi order is only in theory a unitary order. It has, on the whole, been characterized by its orthodox stress on shari' $a$ and a tendency, especially 
in the Near East and Asia Minor, to work closely with political regimes. ${ }^{9}$ Originating in Central Asia, one of the more renowned Naqshbandi figures of Indian Sufism was Shaykh Ahmed Sirhindi, the Mujaddad Alfi-Thani, who attempted to synthesize mystical Islam with the more austere shari $a$ and engaged in a defence of orthodox Islam against the heterodoxy of the Mughal Emperor Akbar. The Naqshbandis in South Asia, unlike Naqshbandis in Turkey for example, thus have a tradition of dissent not found elsewhere.

Sirhindi founded a Naqshbandi sub-order in South Asia known as Naqshabandi Mujaddidi, which stressed the direct, unmediated contact with the Shaykh and his divine grace (faiz). The cult discussed in detail below was not, however, a Mujaddidiyya one, being more eclectic in its practice of dhikr, but it was nevertheless linked through its spiritual genealogy to Sirhindi, via the cult saint's master, Baba Qasim of Mohra Sharif at Muree. Zindapir, the living saint who was the founder of the cult, also highlighted his dissenting stance vis-à-vis Pakistani politicians by stressing their hubris and corrupt practices. The cult was also strictly orthodox in many ways. For example, the pir demanded that his disciples come into unmediated contact with him, forbidding during his lifetime all pictures or portraits of himself, and even the publication of any biographical accounts or poetry written in his honour. At the same time he rarely philosophized about Sufism with close disciples, preferring the use of parables and proverbs to illustrate his esoteric knowledge. As a ta'ifa, a separate regional cult, his cult was identified as belonging to the Sufi order of Naqshbandia Ghamkolia, thus appending the name of the cult centre to the wider order.

\section{The heterogeneity of Diaspora}

Elsewhere, as in my monograph The Migration Process, ${ }^{10} \mathrm{I}$ have written about processes of Pakistani migration and community formation in Britain and Manchester, culminating in the building of the Central Manchester Jam'ia mosque. What makes the Pakistani communities that have emerged throughout Britain diasporic, rather than simply ethnic or religious, I argue, is an orientation in time and space - towards a different past or pasts and another place or places beyond Britain. What makes these diasporas into communities is categorically not their unity. Like Sufi cults, people belong to a diaspora in quite different, materially embodied ways. Some people set up Urdu poetry reading circles. They meet every month to recite poetry in each other's company. Some set up religious discussion groups known as dars. They meet in mosques, homes or restaurants to talk about Islam. Such groups host visiting poets or religious experts from Lahore, London or Delhi. ${ }^{11}$ Some diasporas organize Pakistani political parties and commemorate Pakistani national leaders like Quaid-iAzam, Muhammad Ali Jinnah. ${ }^{12}$ The social heterogeneity of diasporas, their internal complexity, is a central feature of all established diasporas. This is particularly so in the case of South Asian Muslims who orient themselves towards a global Islam while practising a peculiarly Pakistani or South Asian version of that Islam.

In Britain, what is remarkable is the variety and heterogeneity of Sufi groups that co-exist even within a single British city such as Manchester, along with, at a deeper level, their similarities. Most significant I think is the fact already mentioned that all the groups foster national networks which connect Pakistani settlers from different 


\section{Seekers on the path}

places in new social configurations which are both voluntaristic and intellectually exploratory. Seen in a broader sociological perspective, Sufi cults in Britain, like other forms of religious organization, created links between Pakistani communities which go beyond prior kinship, caste or village relations. Such cross-cutting ties, extending into Pakistan, created a consciousness of a broader, elective Muslim community.

There are several distinctive features of Sufi cults which might be worth highlighting:

1 Only some groups attract British-born followers. At present groups are being augmented and reproduced in Britain partly because of a continuous influx of inmarrying young people, both men and women, from the subcontinent.

2 There is a general stress, shared by all the groups, on dhikr, or meditation. Also evident is the heterodox character of Sufism in Britain. Some groups are particularly inventive of new traditions, others veer towards a strict salafiyya (fundamentalist) pole.

3 In some groups the extent of gender equality and mixing is quite remarkable. In others, gender separation is almost total.

4 Many of the British-born or bred followers of Sufi saints in Britain are educated professionals. This highlights the fact that mystical Islam can remain attractive to educated Muslims.

5 Although the groups perceive themselves to be open to members of all faiths and nationalities, in reality groups are composed almost exclusively of men and women of Pakistani background. The dominant language spoken is Urdu, and the cultural milieu distinctively South Asian.

6 All the cult leaders engage in faith healing and amulet writing, and this is clearly a key source of income and new recruits. The belief in afflicting demonic jinns is widespread among young, British-born Pakistanis who have developed a whole lore of terrifying jinn stories. There is some evidence also, however, of disillusionment with Sufi healers, based on in-depth interviews I conducted. ${ }^{13}$

The study in Manchester showed that for young people in Britain of Pakistani origin Sufism is grasped in social and ethical terms, while at the same time it is perceived to lead to an experience of transcendence and to a deeper, more real, form of knowledge. In all the groups, being a disciple leads to a broader exposure to like-minded Pakistanis living in different towns and cities in Britain, and to new kinds of links with Pakistan and Islam.

For the rest of this contribution, I want to focus on three khalifas of Zindapir who exemplify some of the very different ways of being a Sufi in Britain, even within a single, orthodox, Naqshbandi Sufi cult.

\section{The organization man: Building a}

\section{Sufi order in the land of the infidels}

'Sufi Sahib Ghamkolvi who is living in the land of infidels'-so the monthly Pakistani magazine Mouhafiz-e-Haq ${ }^{14}$ opens its account of Zindapir's senior khalifa 
in Britain - is, like 'the perfect saints who spread Islam in India' (here the magazine cites some famous examples), 'taking them out of the darkness of infidelity and lighting the candle of God's and the Prophet's oneness. So too in Britain, from the land of Birmingham a fountain of unity (tawhid) and Prophecy (risalat) has spread all over Europe where preaching and printings quench the thirst of Muslims.'

The article, entitled 'Zindapir's Miracle (karamat) in Britain', goes on to stress Sufi Sahib's qualities as a man of practice and religion (din) with outstanding results: 'The Ghamkolia mosque not only benefits the Muslims of Britain', the magazine tells us, 'but it also gives pride to all British people of the Prophet (Abl al-Sunna, i.e. Barelwi followers)'.

Sufi Sahib, at 77 still a giant of a man, well over six feet tall, with a powerful presence, survived three years in a German Prisoner-of-War camp during World War II, before meeting his pir in Abbotabad in 1945. For the next 17 years he served as a Non Commissioned Officer (NCO) (subedar) in the Pakistan army while also serving his pir, helping to found and build the central lodge at Ghamkol. This long and intimate association with Zindapir during the founding years of the order has endowed Sufi Sahib with an almost mythical status. The days and weeks he spent at the lodge in the company of his shaykh at a time when it was still a wild, uncultivated place, are regarded as a source of immense spiritual power. During those years he was a close companion, helping to bring up Zindapir's small child, Badshah Sahib, when he lost his mother at a tender age.

By the time Sufi Sahib migrated to Britain as a labour migrant in 1962, at the age of 35, he was well established as a trusted companion of the Shaykh. According to his own account, when the pir appointed him a khalifa to Britain he was filled with selfdoubt: 'I am only an ordinary person. How can I perform such an important task?' he asked. Zindapir replied with his usual conviction that since he was embarking on God's work, God would help him. ${ }^{15}$ In Britain he encountered Pakistanis who never prayed and did not even know the location of the mosque or the direction of the qibla. He describes the first 'urs in Birmingham:

There were two other pir-bhais in Britain. The three of us celebrated the 'urs with a mahfil which lasted half an hour.... We made a mosque in one room of our house. When we held the Friday jum'a prayers there for the first time we were only seven or eight people.... Later we began to do dhikr ... in 1964 we began to perform dhikr regularly... Now with the blessing of God we have a mosque, a community centre, ten houses which are the property of the mosque, and a printing press. ${ }^{16}$

He also noted the order's Dar-al-Ulum in Manchester and the school in Birmingham for hafez qur'ans which had so far trained over forty young boys to memorize the text of the whole Qur'an.

I visited Sufi Sahib's Golden Hillock complex in Birmingham in 1994, when the building of the mosque was still in progress. By this time he had created an impressive array of institutions on his property: a community centre, funded by Birmingham Metropolitan Council to the tune of $£ 400,000$, which housed a training college for 


\section{Seekers on the path}

industrial sewing machinists, a wedding and community hall and (in 1998) a centre for the elderly and disabled. Users of the hall were not charged a fee but were asked to make a donation to the mosque. The older terraces in the complex had been entirely refurbished and now housed an employment centre which included a job club for the unemployed, a pre-vocational training centre, information technology training, typewriting, youth training and English language courses. An Advice Centre employed two men and there was also a pre-university access course with an excellent attendance record. Paid workers included a mix of young British Pakistani disciples and English instructors. Upstairs, in one of the buildings, was a hostel for the young boys learning to be hafez. The concentration of services for Asians in a single complex was impressive, providing training in needed skills, and helping to motivate men and women lacking in self-confidence, and to cushion their access and entry into the labour market. This was very much an English way of being a Sufi - acquiring charitable status, establishing a management committee and voluntary organizational structure, serving the community.

The story of the building of the new mosque as told by Sufi Sahib is one of astute and miraculous negotiation with the City Council. Initially, he acquired some terrace houses and a large hut which replaced the downstairs living room of his house as the order's mosque and dhikr meeting place. Then, in 1985, his management committee applied to the Council for additional parking space. The Council offered an adjacent area of 35 derelict terraces. What did the Council intend to do with the rest of the houses? Did it have any other project in mind? Sufi Sahib commented,

Since this place was allocated by God to be a mosque, the City Council told us: if you build a mosque on this area we will sell the land to you for a third of the price. We fell silent for a minute but then we thought: a non-Muslim is offering us a place for a mosque and yet we are hesitating ... we sat together and talked the matter over among ourselves and realised that this is the best place in which to build a mosque. We then drew up a plan and presented it to the City Council. When they saw it, the English started to laugh: how could we build such a big mosque? They laid down a condition that if we failed to build a mosque in eighteen months, they would confiscate the land. We accepted their terms and, by the grace of God, the very day we were given the land, work began. ... We completed the mosque in four years. The mosque has 56 pillars, each 45 feet in diameter. ${ }^{17}$

Fund raising for the mosque involved a major drive. Sufi Sahib and his disciples travelled on weekends to every town and city in Britain, and contributions also came from Europe, from Iraq (which contributed £5000) and from Islamic Relief (Saudi Arabia) which gave $£ 11,000$. All the rest of the money, several million pounds sterling, was donated by ordinary people. 'When people say I built this mosque I say, No, I did not build it, the Muslims built it.' The chandeliers alone in the central hall cost $£ 75,000$ each. 'I am the son of a farmer and have been all my life a factory worker. This is all due to the blessing (karam) of God.' And Sufi Sahib continued: 'My pir has never been to this country but there are fourteen cities where, every week, dhikr 
gatherings are held, and every month, gyarvwin sharif is celebrated [in his name]. So too the 'urs [to commemorate him] is held in fourteen places' ${ }^{18}$

This extension of Zindapir's regional cult to England has, in large measure, been the achievement of Sufi Sahib's tireless organizational work, along with his determination to emulate his saint. Much of the building work at the mosque was done with voluntary labour, cutting the costs substantially. The example set by Zindapir, who used voluntary labour extensively to build up his lodge ${ }^{19}$ clearly motivates him. Like his pir, he says, he never asks murids their names. This is because, as the pir told him: 'If you keep water, those who are thirsty will find you.' The pir also instructed him never to visit the homes of murids as this might arouse jealousy or impose expenses on the murid that he cannot afford, thus causing inconvenience rather than blessing. Like Ghamkol Sharif, Sufi Sahib's mosque is open to everyone. Like Zindapir, he has never, he says, delivered a sermon (taqrir). Even the performance of dhikr is regarded as a miracle (i'jaz) of his saint: in the early days they had had to defend the $d b i k r$ against detractors, but now $d h i k r$ is performed everywhere in Britain.

He describes the new mosque as a 'wonder of Islamic art for Muslims and nonMuslims alike'. Whenever groups come from abroad, he says, the City Council sends them to see the mosque. They are told: this mosque was not built with human power but with the spirituality of the saint of Ghamkol Sharif.

In the conclusion of the article, Sufi Sahib mentions with pride that the processions on Milad al-Nabi and on the 'urs, which started in 1973, today attract thousands of followers of Ghamkol from all over the country, besides thousands of others who join in the march. During the two days of the celebrations, "ulama preach the virtuous deeds of the Prophet and na't singers sing his praises, much as they do at Ghamkol, while the langar is freely distributed. Besides this, thousands of booklets are printed and distributed free of charge, so that 'non-Muslims can understand Islam and our own people know the meaning of the true faith. All this is because of the miracles and grace (faiz) of Zindapir'. ${ }^{20}$

With this, the magazine interview ends. It reveals Sufi Sahib to be in many ways a sensitive and humble person, conscious of his connection and indebtedness to his pir. This sense of humility is echoed by a thesis written about him and the order in Birmingham in the early 1980s. ${ }^{21}$ Draper reports that Sufi Sahib often claimed that his status was low, and abnegated himself as having no spiritual value. Out of the context of public display, Draper says, he revealed a 'humility and melancholy at certain times in contrast to other moments of apparent transcendent serenity'. This is 'in contrast to the personality image which many external critics consider him to manifest, claiming that he is arrogant and self-deluded', and it also contrasts with his large physical build which 'reinforces the image of authority that many feel he possesses'. ${ }^{22}$ As his power and influence have grown, so too, I myself found, has the volume of such denunciations. The pir is said to have become more like a maulvi than a pir (i.e. more concerned with exoteric matters than with spiritual Sufism), to have lost his way, to lack the spirituality of a saint, to be interested only in money or in self-glorification, so that when he invites 'ulama to orate at the "urs, it is only so that they can praise him. 


\section{Seekers on the path}

Draper (who for a while was a disciple himself and a Sufi follower) notes the pir's 'sense of humour and joviality which never extends into triviality but functions as a means of reducing tension... In many ways', he says, 'this sense of humour is the source of his charisma'. ${ }^{23}$ When I first read this passage it surprised me: I had never seen the humorous side of Sufi Sahib's personality, which he clearly reserved for his closest disciples. There is no doubt, however, that the majority of followers both in Britain and in Pakistan respect him very highly, and that he has a reputation for being a meticulously honest man in handling religious donations. It was he, after all, who has for the past forty years organized the annual langar of Zindapir at Mecca, on Hajj, and this has made him widely known even to Pakistani disciples. After 1988, he began to attend the 'urs at Ghamkol regularly, and to dominate the all-night dhikr there. He led the dhikr prayers in March 2000, after the saint's death, much as he always does in Birmingham, with incredible vigour.

There is little doubt that Sufi Sahib has become a significant religious figure in the Islamic Barelwi landscape of Britain. The magnificent mosque he has built and the fundraising drive he initiated, which appealed to all Muslims in Britain and Europe, well beyond the Ghamkolia order, made him a national public figure outside Birmingham and Zindapir's regional cult. That he called the mosque Ghamkolia and acknowledged his continued deference to Zindapir and his family were thus significant acts of voluntary humility. In turn, the family of Zindapir respects his authority in Britain. Yet they feel uneasy about the fund-raising drive. Unlike Sufi Sahib, Zindapir had built his lodge almost entirely with voluntary labour, not through public appeals. Unlike Zindapir, Sufi Sahib has also always permitted open expressions of adulation towards his person from disciples, a form of veneration which Zindapir rejected and repeatedly tried to stop.

The ambiguity of authority was stretched to its limits by the death of the saint. Sufi Sahib was, after all, recognized to be his most charismatic khalifa. At the first 'urs after the saint's death, in October 1999, it was Sufi Sahib who was asked by the saint's son to say the final du'a in place of Zindapir. It was he who led the dhikr (the following year this was changed).

Such interregnums inevitably highlight ambiguities in authority. There is no doubt, however, that Sufi Sahib proved through his actions his continued loyalty and generosity towards the saint and his family. For one thing, he visited Ghamkol at least four times during 1999-2000: first, to see the Shaykh who was already very frail and ill; then, to attend the funeral; then, to attend the "urs in October 1999 (the old annual date); and finally, to attend the "urs in March 2000, the first to commemorate the death of Zindapir. This was on top of a trip to Mecca and Medina for 'umra during Ramadan.

Such tireless devotion from a man of 77 suffering from diabetes and other ailments undoubtedly proved his deep sense of love and commitment: the journey to Pakistan is long and tiring and includes an overnight flight and endless queues at Islamabad airport. During his sojourn at the lodge, Sufi Sahib stayed up night after night, energetically performing dhikr. He showed his solidarity with the family through these gestures of devotion, and on each occasion he brought with him a large entourage of disciples and followers from England. For the family at Ghamkol and the Pakistani 
khalifas who were trying to manage a very difficult transition following the saint's death, the public support given by a person of such charismatic authority, deeply linked to the history of the lodge, who had travelled long distances from a faraway land to be at the lodge - such support was clearly of great symbolic and emotional significance.

Like Zindapir, Sufi Sahib was a supreme organization man. Unlike him, the increase in his organizational power seemed to generate suspicion and resentment among some of his closest disciples, along with accusations that he had lost his spirituality (rubaniyat) and grace (faiz), and had become too materialistic and religiously dogmatic. He never learnt to speak English and most English converts who came to him ultimately found him too 'Pakistani' and abandoned the order. ${ }^{24} \mathrm{He}$ clearly harboured deep suspicions against the 'infidels' (i.e. the citizens of the UK) in the midst of whom he had made his home and who are, after all, the majority in Britain.

This rejection of non-Sunni Muslims is a strand in the Naqshbandi tradition which can be traced to Sirhindi, but it was not the way chosen by his murshid, Zindapir, who, like Baba Qasim before him, was renowned for his religious tolerance and universalism.

Sufi Sahib also resembled Naqshbandis elsewhere in fostering very good relations with local government and with the 'ulama. At the same time he was without doubt one of the most successful Sufi pirs in Britain in attracting young, British born, Pakistani men as disciples, and this cohort was utterly loyal to him. As one such follower told me, these young followers would willingly 'go through fire and water' for him. More than anything, he clearly loved surrounding himself with his young male disciples, eating, sleeping and doing $d b i k r$ in their company, much like a scout leader or the NCO he once was. Sufi Sahib was, above all, an extremely sociable, indeed gregarious, man, a mover and a shaker, not the kind of Sufi who isolates himself in contemplation and meditation.

\section{The Sufi intellectual, and the structuralist quest for gnosis}

Sufi cosmological images are usually deployed in emotional and fragmentary imagery. This tends to disguise the deep structural logic of Sufism, interrupting it with flowery, highly elaborate poetical and ethical interpretations. It was thus unusual to meet a Sufi who had devoted his life's work to proving the highly systematic logic of Sufi cosmology as expounded by Sirhindi and others. Indeed, it was the chance meeting with this self-conscious structuralist which first enticed me as an anthropologist to study Sufism and Sufi orders.

If Sufi Sahib stressed practical worship ('amal) above all else, and Rab Nawaz - one of the closest khalifas of Zindapir in Pakistan who was a poet - expressed his love for his pir in poetical and ethical terms, another English khalifa of Zindapir, Hajji Karim, founder of the branch and mosque of the order in Manchester, sought ultimate knowledge of transcendent, eternal spheres. He was not satisfied with 'amal which did not open up the gates to gnosis, nor did the experience of love for his saint delude him into thinking that he had experienced true mystical revelation. Having mapped out all the Sufi conceptual schemata systematically, on the basis of his readings, he was seeking the specific key which might unlock the experiential and epistemological 


\section{Seekers on the path}

gates to this universe. Idle talk of love or idiosyncratic references to Sufi terms were of no interest to him. He was a seeker for the Truth (haqiqat) beyond the ephemeral world of experience. His inability to reach this world filled him with sorrow. After Zindapir's death in 1999, and even before it, he began to seek another murshid who might guide him to spheres of divine knowledge which his Shaykh, the Shaykh's son and Sufi Sahib, had all failed to guide him towards. He took textual constructions of Sufi cosmology to be a literal description of a reality out there.

Through an elaborate series of diagrams which he constructed in Urdu based on Naqshbandi sources, Hajji Karim highlighted a series of oppositions and homologies: between body and cosmos, the ephemeral versus eternal worlds, carnal versus eternal soul (nafs and $r u b$ ), exoteric and esoteric, saints versus prophets, shadows versus truth, attributes versus essence, body lights versus body matter, all in ascending, hierarchical order. The movement he outlined is upward, through sainthood to prophethood, from the shadows through the attributes to the essence, and then back again, to incorporate on the way down the base body and achieve a final physical transformation. In these parallel worlds of microcosm and macrocosm, body and cosmos, the mediators are, on one side, sainthood/the throne of God, and on the other, the human heart. Each mediator participates in both the higher and the lower world. In Sirhindi's thought, represented by Karim in a series of spherical diagrams, each world reached opens up new worlds but the generative principles remain constant throughout.

What are we to make of such indigenous structuralist models? Structuralism has been the subject of powerful critiques from interpretivist and post-structuralist approaches. In the present instance a speculative mystical philosophy presents itself as an accurate science. The bricoleur is not an experimenter, as Levi-Strauss recognizes. ${ }^{25}$ Because it is entirely speculative, Sufism is not bound by empirical realities. Nevertheless, the language and logic of science lends it authority and verity despite the fact that in many ways it is a highly tentative set of propositions, so that Sufis ultimately must rely on image and representation rather than on scientific evidence to make their claims.

As mentioned, Hajji Karim relied upon published sources in Urdu, including the letters of Shaykh Ahmad Sirhindi and the writings of other Naqshbandi texts, as well as on his discussions with his fellow khalifas in Birmingham. Our conversations on Sufism took place during innumerable sessions at his home in Manchester and at the lodge in Pakistan.

Hajji Karim is a British Pakistani from Mirpur. When we first started our conversations he was approaching 40. He came to England in his early teens to join his labour migrant father. Leaving school at 16, he worked for many years in a foundry, where he first met Sufi Sahib, and through him became a disciple and then khalifa of the saint in Pakistan. Despite his lack of formal education, what is remarkable about his account of Sufi philosophy is its total integration and sheer structural brilliance. Although Sufi Karim's mastery of texts has not enabled him to reach personally to the elusive realms of Sufi knowledge, it nevertheless supports his continued faith in Sufism.

During the course of my research I was repeatedly told that hidden knowledge in Sufism is arrived at through experience rather than through intellectual scholarship; the way to gnosis is via the heart, through the practice of dhikr and the love of a shaykh. 
This Sufi privileging of knowledge as experience over knowledge gained from written sources is one which may be subverted, since esoteric knowledge is paradoxically a more public commodity than the mystical experience it supposedly reflects. This has not, however, undermined the charismatic power of the saint, for the 'real' hidden knowledge believed by his disciples to lead to mystical revelation is of specific technical directives - practices of seclusion and meditation associated with the repetition of Qur'anic verses and wazifas (litanies) - which only the saint knows, and which are thought to be the sole means of advancing on the Sufi path. The saint's ijazat, permission, is essential before embarking on any form of ritual practice. Without his knowledge and guidance, it is believed, a person may go mad, be 'lost' forever in mystical ecstasy.

Hence it is Sufi written texts - rather than revelation through experience - that may open up for ambitious disciples the realms of gnosis and the religious imagination. But these Sufi texts also serve to legitimize the saint's absolute authority. This is because, although disciples may have read widely in Sufi Naqshbandi texts, the key, they believe, to the realms of Sufi secret knowledge-as-experience still lies ultimately with the saint, and the saint in this case refuses to talk about these matters altogether. Hajji Karim remained a disappointed man. In this he differed from another khalifa of Zindapir and Sufi Sahib, a genuine modern scientist who has nevertheless embraced Sufism as a way of life.

\section{The English scientist}

Dr Alam Din, Zindapir's khalifa at Pennine, ${ }^{26}$ a small town in Derbyshire, is a prominent scientist working at the cutting edge of current research in genetic therapy. $\mathrm{He}$ has a full-time permanent research post at a major British university. Dr Din is a youngish, thin man, about 40, sporting a dark beard and glasses and dressed in modern casual clothes. He speaks softly, in measured tones, at times breaking into a mischievous smile or grin when he suddenly becomes quite English. He grew up in England, arriving from Kashmir as a boy of about 9. Like Zindapir, he seems able to switch from a tone of deep piety to witty, cuttingly critical remarks. With his genuineness, integrity, quiet assurance, natural modesty and willingness to take risks and act independently, his persona radiates a measure of personal charisma.

Dr Din's father was a khalifa of Zindapir and a recognized minor pir in his own right. After his death, Dr Din took over his responsibilities as khalifa and juggles these with his full-time job as a scientist. He made little attempt, however, to describe Sufism to me as a scientific theory. Instead, his stress was on identity and identification:

Here in England our link to Zindapir was always mainly spiritual and I feel that this spiritual connection has actually increased after his death. I feel his presence all the time, he supports me, I am nothing without him.

The first time he met Zindapir was after his father's death and burial in Mirpur:

... the first time my eyes fell on him it looked as if I had come back to see my father. Hazrat Sahib looked exactly like father, with a sideways view, and I thought, 


\section{Seekers on the path}

I've come back to my father. And that was [intended] for my peace of mind, to say that your father has not left you, he is still with you, but now physically in Hazrat Sahib's body [in other words, the saint created the resemblance deliberately in order to comfort him ] ... and therefore, you know, Hazrat Sahib is not only my shaykh but my father figure. And so Hazrat Sahib gave me the responsibility of the kbilafat that my father had; that was something beyond imagination.

He then told me of an admonishing letter sent to him by Zindapir following a scientific meeting he had attended in Switzerland where he omitted to observe some of the prescribed daily prayers. This miraculous knowledge from a distance strengthened his faith: 'I feel that, you know, he is there any time I need him, he's watching over me.' He also told me of his good fortune in getting his present post, having been passed over for another, apparently superior job. Although his present job had started at a lower level, it was followed by rapid and multiple promotions. He attributed this to God's will. The connection to the Shaykh gave him the will to continue with all the events of the order, the weekly dhikr, gyarvi, milad, 'urs, consistently without gaps.

There were some rumblings from other disciples when he got the khilafat from the Shaykh at a very young age. 'I got the khilafat when I was 33 and I also got my Ph.D. when I was 33.' The branch in Pennine was built up slowly by his father and at first, even the performance of dhikr was greeted with criticism. But from the very start he had loved doing dhikr and never missed the Friday mahfil, even when he was a student in London.

After $d$ hikr you physically feel very tired, if you've done it properly, but mentally and spiritually you feel very enlightened, you feel as if a burden has been taken off you, you know, and it broadens the mind, it opens, it, you start, you have a problem, you think about it and the answer comes to you. Afterwards, yes. Yes, it helps you to find solutions yourself.

[P.:] It's a very deep form of contemplation?

[Dr Din: $]$ Oh yes, it is the only worship that automatically becomes worthy of acceptance. In prayer when you are prostrating in front of Allah and you've made your niyat, your intention, and during prayer, namaz, it is impossible to have your mind and tongue and heart united in what you're doing. Usually, most of the time, almost invariably, your mind is thinking about something else and your tongue is saying something else and you don't know where your heart is. So that kind of worship is not worthy of acceptance. In $d h i k r-A l l a b$ you have no choice: you are shouting at the top of your voice, 'God is Great,' and you are sitting in darkness, removed from distractions, you cannot shout at the top of your voice without having your mind, your tongue and your heart united, and those are the conditions of getting your worship accepted - when your mind and your heart and your tongue are united in the same.

He admitted that he had not even reached the first step on the Sufi path but at the same time, his Shaykh had given him 'close attention' (i.e. tawajjub) that 'even 
decades of worship can't take you there. That is the difference, that is why I feel I am lucky, because other people do worship for decades before they reach this stage when they can get the attention of their shaykh.'

He knew he had this 'attention' after he was reprimanded by Sufi Sahib during Hajj for supposedly backbiting against another kbalifa who was acting as darban, the gatekeeper of the saint. He felt mortified and tried to persuade Sufi Sahib to come with him to the Shaykh to explain that this was not his intention, but to no avail. Sufi Sahib refused. Eventually, he mustered up his courage and went to see Zindapir on his own. He told the Shaykh that he had really meant to praise the darban. Zindapir looked at him and said, simply, 'I love you.' He just said, I love you, and he, Dr Din, believed him. Zindapir knew what was in his heart. How could Sufi Sahib believe his intention was bad? He, Sufi Sahib, is not a proper pir, he cannot see into people's heart.

He is a shy man, he said, but now he finds himself greeting strangers. And people come to him for healing from all over: Nottingham, London. He makes no claims but they still come. Sometimes there are queues outside, every night, even in winter. $\mathrm{He}$ even has permission to initiate disciples. His aim is to bring the true message of Islam to England, not the one promoted by fundamentalists. He runs the Friday jum'a prayers at the hospital. In this context he gave me a short summary of the four stages of Islam (TSWF): Tauba (repentance), saf (purification), wali (friend of God), fana fi Allab (annihilation in God, the complete merging with God). The first stage is to be lost in the daman (robe), the being, the body, of the pir, then the Prophet, then God.

Like most murids, Dr Din feels loved and chosen by his saint. For him the Shaykh is his father incarnate, his spiritual guide, his protector and comforter in the absence of a real father who died when he was quite young. His Sufism is for him a source of identity and conviction which complements his role as an English scientist and anchors him deeply in his local community, giving him a role, a standing and a mission. And yet one did not feel, in talking to Dr Din, as one did talking to Rab Nawaz, the khalifa-poet of Zindapir, that he missed Zindapir the man following his death. The Shaykh remained an exemplar, an emblematic figure, an imaginary - all of which continued to exist and to give him strength.

\section{Conclusion}

Each of the men considered here: Sufi Sahib, Alam Din and Hajji Karim, embarked on their own life projects partly through intense emotional identification with their saint in Pakistan. Only Hajji Karim constructed this project in purely intellectual terms. Unlike Zindapir, the cult in Britain headed by Sufi Sahib has, over time, generated a measure of conflict and suspicion, although often muted. Building up a religious empire in Britain has involved certain choices for Sufi Sahib of which other disciples disapproved. As his material dominion has expanded, so too has Sufi Sahib's spiritual reputation among early disciples and khalifas diminished. He is now seen by some to be corrupt, vain and power seeking. For others, he has become too closely 


\section{Seekers on the path}

associated with the "ulama and their perceived prejudices and exclusions. His alienation from British society is a problem for many. Yet he has retained an aura of charisma and a large devout following among ordinary disciples throughout Britain. In his own eyes, he clearly remains a humble follower of his murshid, his perceptor and guide.

As a diasporic Sufi cult centred on Pakistan, Zindapir's regional-cum-global cult has been remarkably successful. It is perhaps the largest ta'ifa in Britain, and its international extensions into Afghanistan, the Middle East, Southern Africa and more recently Europe and the United States, have developed through sub-centres linked in viable connections to the original sacred centre founded by the saint at Ghamkol Sharif. Yet the following is still almost entirely composed of South Asian migrants and their descendants. Zindapir's cult has expanded in tandem with postcolonial migrations to the West. He began as an 'army' saint (he was a tailor-contractor accompanying the British and later Pakistani armies) with a following of disciples drawn from the army, the police and government service. These followers, once retired from army or government service, have extended his name globally wherever they migrated.

\section{Acknowledgements}

The research on which this contribution is based was supported by generous grants from the ESRC and the Leverhulme Trust during 1989-91 and 1999-2000.

\section{Notes}

1 There is a large literature on the spread of Sufism into South Asia (see, for example, Eaton 1993).

2 On the organization of ta'ifas, see Trimingham (1971); on regional cults see Richard Werbner $(1977,1989)$.

3 For a more elaborate discussion of langar see P. Werbner (1998).

4 See Werbner (1977).

5 See Frembgen (1998).

6 Elsewhere I have written on the notion of 'chaorder' as a feature of diasporas which lack central command structures, yet develop along predictable lines (see Werbner 2002b).

7 See Buehler (1998).

8 See Werbner (2003).

9 There is an extensive literature on the Naqshbandis, both in South Asia and elsewhere, and on Ahmed Sirhindi, a key figure (see, for example, Schimmel 1975).

10 See Werbner (1990a).

11 See Leonard (2000).

12 See Werbner (2002b).

13 See Werbner (2003).

14 Feb-March 2000, pp. 7-9. The article is in Urdu, and was translated by my research assistant.

15 Ibid.

16 Ibid

17 Ibid.

18 Ibid.

19 See Werbner (1998). 
20 Ibid

21 See Draper (1985), p. 26.

22 Ibid.

23 Ibid.

24 See Draper (1985).

25 See Levi-Strauss (1966).

26 Pennine is a pseudonym. 


\title{
8 Learning the lessons from the neo-revivalist and Wahhabi movements
}

\author{
The counterattack of new \\ Sufi movements in the UK
}

Ron Geaves

\section{Introduction}

In the last fifty years Britain's Muslim presence has been transformed by the arrival of various populations, predominantly from Pakistan and Bangladesh, but also from Malaysia, Turkish Cyprus, Iran, Yemen, North, West and East Africa. These are all places where, either historically or as a living faith tradition, Sufism is significant. Although slow to organize themselves in the British Muslim diaspora, the last twenty years has seen the transplantation of several prominent Sufi tariqas, including various offshoots of the Naqshbandis, Chishtis, Qadiris, Mevlevis, Alawis, Shadhilis and Tijanis. The establishment of these tariqas has provided a series of organizational structures to the prevailing tendency towards 'folk' or 'popular' Islam in the above populations who mostly originated from rural areas. The tariqas have capitalized on the strong empathy with the teachings of traditional Islam $^{1}$ as embodied within Sufism and in recent years have been able to provide a unifying Islamic discourse based on practice and belief and drawing upon the traditional loyalty of the above populations to the leadership of pirs and shaykhs rather than the ulama. In spite of the strong presence of orthodoxy manifested in Wahhabi and neo-revivalist movements, it is nonetheless true to say that the British Muslim population is predominantly traditional rather than orthodox and maintains a strong Sufi allegiance. ${ }^{2}$

There are several reasons why Sufism and the forms of Islam influenced by it were slow to develop in the British context, in spite of the fact that the very first Muslim communities which developed in British ports were organized around a Sufi tariqa. ${ }^{3}$ The first reason for the slow start can be located in the nature of migration patterns. The original small communities of single men, later joined by wives and children, which was the traditional pattern of economic migration, at least from the dominant communities from Pakistan and Bangladesh, were focused in run-down urban areas where cheap manufacturing industry labour was required. The communities were not initially large enough to sustain more than one mosque. Decisions were taken to create mosques to provide places of prayer that would not reflect any kind of sectarian divisions in the community. In order to achieve this, Muslim practice and belief was stripped down to exclude any regional or traditional elements. This emphasis on removal of any perceived cultural accretions played into the hands of both nineteenth 
century reform movements such as the Deobandis, as their central criticism of Sufism emphasized practices and doctrines that were considered to be deviations. The predominantly rural Muslims who owed their allegiance to tradition-laden Islam were deprived of their familiar patterns of worship and only began to create their own mosque network once the communities were large enough to sustain enough places of worship to represent full Muslim diversity.

In the meantime, imams for the first mosques were chosen from among the leaders of the community on the basis of age, education and background. The founders of the mosques were usually better-educated migrants from the cities of the subcontinent. They were natural leaders of the community and more confident to take the initiative in a new alien environment. However, this was bound to cause problems as the communities grew. The congregations of the mosques were overwhelmingly from rural backgrounds. It is certainly accurate to say that the historical divisions between traditional Muslims with an allegiance to Sufi-influenced Islam and the nineteenth century reform movements such as Deoband and Ahl-i Hadith paralleled a rural/urban divide. The educated mosque leaders were more inclined to reform ideas and began to invite imams from the subcontinent that were trained in the Deobandi Dar al-ulums. The predominantly rural origin congregations of the mosque with strong allegiances to shrines and saints often found themselves in opposition to their imam and the more educated mosque committees. A particularly painful period in the development of British Islam occurred as a result of this tension. As imams began to preach to their congregations against the time-honoured customs practised in the place of origin, conflict began to break out. In time the congregations began to organize behind their own leaders, especially when shaykhs of the tariqas began to arrive in Britain, but the process led to serious divisions in the Muslim community. ${ }^{4}$

The third reason for the slow development of any coherent national identity laid in the nature of the tradition itself. Although the efforts of Ahmad Riza Khan (1856-1921) had resulted in the possibility of traditional Muslims of India developing a common identity around the label of Abl al-Sunna, later to be known commonly as Barelwi, and instigate a counterattack to the criticisms of the reformers, this kind of Islam practised by rural people involves a wide range of local customs established by oral tradition or kept to particular locale through being focused on a regional Sufi shrine. ${ }^{5}$ The movement to Britain deprived the adherents of this locale-based practice with the infrastructure or spiritual geography around which they had focused. Stephen Barton in his study of Bengalis in Bradford argued that it is unlikely that the shrines could be replicated in Bradford and the focus of these Muslims would remain in the place of origin through remittances and journeys home. ${ }^{6}$

My own investigations of the Chishti presence in Britain confirmed Barton's view. The sajjada nashin who maintain the dargab at Ajmer refuse to establish centres of Islam in Britain where the tariqa can be organized. They maintain the focus of attention on the shrine of Mu'in al-Din Chishti or his descendents in the subcontinent. Remittances are collected to maintain the shrine centres and visiting shaykbs from the shrine help keep the attention of their audiences on problems in the subcontinent rather than organizing themselves in a British context. The pirs provide a counselling service in which attention is again shifted away from Britain, either by visits to the 


\section{Learning the lessons from the neo-revivalist and Wabhabi movements}

dargah or correspondence to the subcontinent pirs. There is little acknowledgement that unique solutions need to be discovered to deal with the problems of Muslims in Britain, especially those facing the younger British-born generations. ${ }^{7}$

Added to the above problems were a number of internal divisions among the supporters of traditional subcontinent Islam. These primarily lie in the fact that the prime loyalty of adherents is not to a sense of a unified tradition, or even to an established tariqa but to an individual pir or shaykh. Each group of murids creates separate organizations where membership is restricted to the murids themselves. Very often fierce loyalty to a shaykh results in criticisms of other murids and their spiritual guides.

\section{The reform movements'critique}

The reform movements were quick to capitalize on these divisions and weaknesses inherent amongst the followers of traditional Islam. A number of such movements had arrived with the migrants from the subcontinent. Foremost amongst them were the Deobandis, a traditional rival of the Barelwis founded in the nineteenth century and Jama'at-i Islami, a twentieth century religio-political movement founded by Maulana Maududi. ${ }^{8}$ Although not particularly friendly towards each other, both were strongly anti-Sufi.

The Deoband school had come into existence as a result of the British consolidation of power after the failure of the uprising in 1857. Many Indian Muslims realized that jihad would not succeed in restoring them to power and sought other strategies to restore former glories. Whereas reformers like Sayyid Ahmad Khan recommended learning from western science and technology through acknowledging the supremacy of western education, others felt that Islam could be revitalized by a return to a pristine purity based on a perceived ideal community of early Muslims around the Prophet, particularly in Medina. The founders of Deoband blamed the downfall of Islam in India on a corrupt faith spoiled by cultural accretions creeping in from the Hindu majority culture. They believed that Sufism was the repository of this corruption of Islam. The objective of the founders of Deoband was to create a network of Dar al-'ulums where Muslims could be educated in their faith stripped of any impurity arising from contact with beliefs and practices originating in Hinduism or Christianity. The concept of a network of Dar al-ulums was very successful and by 1967 , it was claimed that there were 8934 Deobandi schools and colleges in the subcontinent. ${ }^{9}$ Deoband had become more than an educational institution; it was established as an independent school of thought whose main aim was to protect and revive Islam through concerted efforts to purify the faith.

The Deobandis were very quick to organize in Britain. The first mosques to be created in British cities were often Deobandi-led initiatives. By 1967 they had founded the Majlis Ulema UK, an organization to co-ordinate their activities and allow Deobandi 'ulama to come together in conferences, plan tours, publish materials and to issue fatwas in order to ensure correct practice. The rapid growth in mosques between the end of the 1960s and the 1990s provided a demand for qualified imams able to provide religious leadership to the migrant communities. Deoband education gave its graduates a thorough training and access to a unified organized curriculum. To the 
middle-class Muslims dominating the mosque committees, Deoband's reputation for scholarship and religious orthodoxy appeared to supply the correct Islamic values necessary to provide the spiritual needs of the newly established communities.

The Deobandis were also quick to realize that it was essential to provide the means to successfully maintain the loyalty of young Muslims born and educated in Britain. In order to achieve this they began to create a network of Dar al-'ulums in British cities that could train young British Muslims as imams more qualified to deal with the problems faced in the British context.

However, the reforms begun by Deoband have now been continued and surpassed by the radical programmes of the twentieth century lay Islamic movements with their political agenda to revolutionize Islam. The Deobandi presence in Britain has remained insular, conservative and primarily intent on maintaining the traditions and way of life established in the subcontinent. Although intent on attacking Sufi practices, this was essentially achieved from the pulpit at Friday prayers, where the imams loyal to Deoband focus on eliminating rural customs of subcontinent Muslims by declaring them to be bid'a (innovation). This continuation of battles imported from the subcontinent may have been an irritant to the followers of traditional Islam with their roots in Sufism but it was an enemy that they knew well from over one hundred years of skirmishing. It did not, however, appeal necessarily to the younger generation, who became tired of old religious and ethnic battles imported from the subcontinent and increasingly looked for Islamic movements that would address the problems of being Muslim and British.

The Jama'at-i-Islami organizations quickly grasped the necessity to focus on youth and their influence has been profound. Although their overall membership is small they became effectively the prototype for a number of organizations that can loosely be stated to represent the Islamic Movement. ${ }^{10}$ These organizations identify themselves with the struggles of various groups throughout the world who are engaged in a struggle to implement radical change in their societies utilizing Islam as their ideology, rather than cultural and ethnic identity problems originating in the subcontinent. In this way, these organizations in Britain are able to provide an identity for their members which extend outwards to the wider Muslim world. They consciously promote an Islamic identity over and above ethnic or national identity, and they programme actively to move away from South Asian customs and traditions. All the groups openly identify with the ideology and politics of the Islamic Movement throughout the world, and it is this emphasis on promoting Islam for British Muslims whilst at the same time identifying with Islam worldwide that has proved so attractive for many young Muslims. If anything, these groups that identify with an Islamic Movement are more anti-Sufi than the members of the earlier nineteenth century subcontinent movements, in that they share the belief that Sufism has led to the downfall of Islam through introducing non-Muslim beliefs and practices but also perceive these beliefs and practices as superstitions belonging to a rural population that can have no place in contemporary urban environments amongst educated Muslims committed to revitalizing their faith.

Throughout the 1980s the conflicts between the Deoband-inspired schools and the Barelwi mosques had begun to die down. They were beginning to work more closely 


\section{Learning the lessons from the neo-revivalist and Wabhabi movements}

with other in the interests of the wider community and had discovered the pragmatic advantages of Muslim unity to achieve political and religious rights. Mosque conflicts had almost ceased as respective supporters of each group could find affiliated mosques without moving too far from home. From the confidence of their own territories they were able to find institutional avenues for consultation with rival groups in regard to issue that affected the wider Muslim community such as diet, dress and religious education.

In the 1990s new groups arose with loose loyalties to the Islamic Movement who were committed to criticizing the beliefs and practices of traditional Muslims. Very often these groups were influenced by developments in the Muslim world that were nothing to do with subcontinent history and had little respect for pragmatic truces created by Muslims originating from that region. They recruited on university campuses and brought their campaigns to the streets. They were aggressive and not afraid to set up their stalls of promotional literature outside the mosques loyal to prominent Sufi shaykhs. Muslims loyal to Sufi-influenced Islam would find themselves confronted by ardent young missionaries on leaving their own religious gatherings. ${ }^{11}$

Foremost among these new critics of traditional Islam were Hizb ut-Tahrir ${ }^{12}$ and the group which identifies itself as Salafi. The Salafi movement began in the MiddleEast in the 1880s and 1890s in reaction to European cultural domination. They called upon Muslims to return to a pure faith as practised by the Salaf (the first three generations of Muslims cited in Hadith as the most devout and correct in their practice and belief). As with the Wahhabis and the Deobandis, the essential message of the Salafis was the removal of all perceived accretions believed to have been added to the message of Islam by the generations since the earliest followers of Islam. The original Salafi attack was not directed at the West but at fellow-Muslims, especially those belonging to Sufi tariqas, who were seen to have destroyed the world of Islam from within by introducing non-Islamic innovation. The Salafi message has continued to be promoted by new generations of ideologues represented in Britain by two western converts, Bilal Philips and Dauod Birbank. ${ }^{13}$

Generally, the world of traditional Islam labels all of its critics 'Wahhabis' after the movement founded in Arabia by Muhammad Ibn 'Abd al-Wahhab (1699-1792). In brief, Muhammad Wahhab organized the Bedouin tribes in a concerted Islamic reform movement dedicated to restoring a pure Islam based on a rigid interpretation of tawhid. His main attack fell on the Sufi tariqas and the practice of venerating the shrine-tombs of Sufi saints. His followers destroyed countless graves of Sufis in the region of Arabia. In fact, the label 'Wahhabi' or more recently 'Wahhabi/Salafi' describes a host of movements who may not have anything in common with each other than the shared belief that Islam should be purified of perceived cultural accretions or innovations added over the generations to the pure faith of the Prophet and the first generations of believers. Most of the beliefs and practices of the Sufis fall into this category and are heavily criticized by such movements.

Carl Ernst has noted that the Sufi tariqas have been criticized by both Muslim modernists and the nineteenth-century revivalist movements, and this criticism has been continued by the various movements usually defined as 'fundamentalist' in the 
twentieth century. He states that Sufism is perceived by them as an 'enemy of Islam only slightly less threatening than Western secularism, ${ }^{14}$ in spite of the fact that these revivalist movements and their sympathizers consist of only around 20 per cent of any given Muslim population. ${ }^{15}$ Even back in 1971, Trimingham argued that the Sufi tariqas were in decline and danger of disappearing altogether under the dual threat of modernization and the Wahhabi/Salafi critique heavily supported by propaganda materials funded by the superior wealth of the Saudi regime. In particular, he shared the concerns of the tariqas that they would lose the loyalty of their secular educated children. ${ }^{16}$ However, this has not materialized: during the decades of the 1980 s and the 1990s, the tariqas have revived themselves as they have begun to fight back against the Wahhabi/Salafi critique, and the twenty-first century dawns with battle lines drawn up between these two conflicting groups within the world of Sunni Islam.

Joffe argues that this rigid separation of the two traditions into competing and antagonistic movements is something new. He suggests that in the past, the competing beliefs were defended by individual scholars such as Ibn Taymiyya but there was 'an integrated and graduated spectrum of belief between the two extremes of religious practice'. ${ }^{17}$ Joffe agrees with Gellner that the increasing divide between rural and urban Muslims is helping to create ideological differences drawn along class lines where middle-class professionals and educated elites are more likely to be attracted towards the reform movements. ${ }^{18}$ As mass education spreads through the Muslim world it will bring with it new recruits to the movements who promote 'scripturalist' Islam. Increasingly, Muslims loyal to the tariqas have become concerned that the combination of urban environments, western education and the secular ethos will provide the conditions in which they will lose their children either to the attractions of the pursuit of material pleasures or to recruitment by the better-organized reform movements.

\section{The counterattack}

The subcontinent Barelwis, with their custom-laden version of Islam focused on the intercession of saints and the Prophet, shrines, baraka (the power to bless), miracles and the performance of dhikr maintained within the shaykh/murid relationship, had never been able to organize themselves nationally in Britain in spite of their numerical superiority. It is obvious that this form of Islam evokes very powerful symbols of places of origin for first-generation settlers, but there was always a question mark over its ability to maintain the loyalty of British-born generations who were beginning to distance themselves from their parents' rural origins in the villages of South Asia. Recession, poverty, unemployment and lack of opportunity provided an environment of alienation and resentment from which the neo-Wahhabi and Salafi movements could recruit with their radical political agendas and rhetoric of jihad and khilafah. On the other hand, the spirituality of the Sufi path offers an alternative to those disenchanted with the materialist ethos of twenty-first century Britain. ${ }^{19}$

Throughout the 1970s and 1980s a number of factors had begun to develop some sense of united Barelwi identity amongst subcontinent Muslims, although these had not spread to other like-minded Muslims from other parts of the Muslim world. The 


\section{Learning the lessons from the neo-revivalist and Wabhabi movements}

work achieved by Ahmad Riza Khan to create a common identity against reform movement criticisms formed an historical foundation which could be built upon in Britain. Most importantly, Ahmad Riza Khan had argued that the followers of traditional Islam should assert themselves to be Abl-i Sunnat wa-jama'at rather than Barelwis. This label provides the possibility of claiming to be the legitimate form of Sunni Islam as practised by the vast majority of Muslims throughout the world rather than a sect or school of thought confined to the subcontinent. By claiming to be the true orthodoxy of Islam, the tables can be turned and the various reform movements can be accused of being a sectarian innovation bundled together as Wahhabi.

The arrival of a number of charismatic Sufi pirs and shaykhs from the subcontinent provided the impetus for greater cohesion as they formed powerful groups of Barelwis able to construct mosques and produce promotional literature to counter the reform movement's criticisms. ${ }^{20}$ However, the traditional loyalty of each group of murids to their own shaykh counteracted this push towards a stronger and more assertive identity. To some degree this was overcome by the publication of The Satanic Verses and the controversial events that took place in the late 1980s as British Muslims struggled to express their anger and outrage against its author, Salman Rushdie. Although disorganized, riven by loyalty to individual shaykhs and lacking the language skills to deal with the media, the Muslims of the Abl-i Sunnat wa-jama'at pride themselves on their love for the Prophet. For this reason Nielsen states that their communities were 'collectively more prepared to register the insult contained in the book'. ${ }^{21}$ The experience of resistance and collective struggle not only helped the Barelwis develop a shared consciousness but it also provided openings for their leaders to take a larger role in issues that affected the British Muslim community as they cooperated in the interests of the common good with other non-Barelwi groups.

In spite of these developments throughout the 1980s, there remained huge hurdles to overcome before the Abl-i Sunnat wa-jama'at could successfully compete with the reform movements' ability to organize themselves, promote their message and recruit from British-born Muslims. The greatest challenge would be posed by ethnic loyalties. As young Muslims grew up in Britain the challenge of identity formation moved some of them towards the ideal of a British-based Islam with its roots in the universal teachings of the Qur'an and Sunna rather than the ethnic loyalties of their parents' generation. The reform movements focused on doctrine and the universal umma and the Abl-i Sunnat wa-jama'at needed to provide its own claim to legitimacy. Unfortunately the shaykhs who had come to Britain continued to promote allegiances that were narrowly confined to ethnic identity. Although some shaykhs were aware of the need to create a national consciousness amongst traditional Muslims they were not able to succeed, because local organizations of Muslims duplicated loyalties formed over hundreds of years in a particular region of origin. As Roger Ballard points out in his own contribution to this volume, these begin with biradari or local extended family networks which retain traditional links with villages of origin, local shaykhs and regional shrines. For example, the Chishti tariqa in Britain remains focused on the shrine of its founder in Ajmer and helps maintain subcontinent norms and values rather than assisting the development of the Abl-i Sunnat wa-jama'at in Britain. On the contrary, children are sent back to the shrine to rediscover their religion and 
culture when perceived by their parents to have been too powerfully influenced by British culture. ${ }^{22}$ Other mosques, such as the Sultan Bahu Trust in Birmingham, are controlled by sajjada nashins, the descendents of a prominent Sufi saint and guardians of his shrine. Although they replicate and rejuvenate the silsila in the new context of migration, the followers remain linked to a particular locality in Pakistan. ${ }^{23}$ This is also true of tariqas from other parts of the Muslim world present in Britain such as the Tijaniyya which is confined to the West African presence in London; the Shadhili 'Alawi, who although North African in origin, arrived in Britain amongst the Yemini settlers in the seaports; and the Bani 'Alawi, which although of Yemini origin, has found its footing amongst East African Asian Muslims who arrived in the 1970s.

Other shaykhs from the subcontinent have been intensely aware of the need for unity. Pir Marouf, one of the prominent pioneers of Islam in Britain, has tried to promote the Abl-i Sunnat wa-jama'at on a wider national front by attempting to create umbrella organizations but his efforts have been hindered by the ethnic boundaries and the loyalty of followers to their individual shaykhs. ${ }^{24}$ In the context of transforming traditional tariqas to provide an environment in which the followers of the $A b l-i$ Sunnat wa-jama'at can develop unique British forms of the tradition with the potential to overcome local identity based in the place of origin, two branches of the subcontinent Naqshbandiyya are significant.

The Hijazi Naqshbandis and the Ghamkholvia Naqshbandis are typical of subcontinent Sufi tariqas in that they both operate from strong city bases in Britain from which they have been able to promote national initiatives to transform the traditional modus operandi of the Abl-i Sunnat wa-jama'at. The presence of Sufi 'Abdullah in Birmingham, where he has established the largest mosque in Europe, provides the opportunity to study the impact of a living charismatic shaykh on the surrounding Muslim community. Sufi 'Abdullah's presence in the city has enabled the tariqa to expand beyond its Mirpuri majority and attract followers from all the regions of Pakistan and young British-born Muslims. There are even signs that a small number of white and African-Caribbean males are beginning to be attracted to the shaykh's spiritual presence and convert to Islam. The Ghamkolvia Naqshbandis are also aware of the need for unity and have tried to create umbrella organizations for all the mosques loyal to the Abl-i Sunnat wa-jama'at in the Midlands to come together for the benefit of the wider Muslim community. Mirpuri in origin, Sufi 'Abdullah does represent any of the major regional ethnic identities present in Britain amongst the Pakistani community but his reputation as a living holy man can attract followers from all representatives of Pakistani communities in Britain. However, the tariqa still needs to be more aware of the needs and aspirations of British Muslims before it can be truly successful in overcoming ethnic loyalties.

The Hijaz Naqshbandis are significant in that they are the first British tariqa to be inherited by British-born and educated Muslims after the death of their father, Pir Wahhab Siddiqi. Like the other pioneer shaykhs from the subcontinent, Pir Wahhab Siddiqi had built up his base in a particular city with a major Muslim presence. In this case it was Coventry, however, the shaykh was always aware of the need that the new community in Britain must transcend ethnic and religious differences which he felt would alienate the younger generation. In particular, he was concerned with the level 


\section{Learning the lessons from the neo-revivalist and Wabhabi movements}

of Muslim education achieved by the Abl-i Sunnat wa-jama'at's leaders in this country who, he felt, should be able to provide solutions to both the religious and material problems of living as a Muslim minority. His vision was a united Muslim community led by imams who would also be qualified as lawyers, accountants and doctors through graduating from British universities. He began by ensuring that his own four sons, who would one day inherit his work, were capable of manifesting his vision. All four sons have taken on the challenge to continue their father's religious leadership of the British Muslim community and provide guidance to the murids of the tariqa. Each of the sons is a graduate from a British university as well as being educated by their father in Islam. The new shaykhs have moved the centre of the tariqa's activities away from the mosque in Coventry to a college in Nuneaton whose grounds also contain their father's shrine. The college has become the focus for fulfilling their father's vision for the British Muslim community through providing an education that mixes both traditional Dar al-'ulum curriculums with GCSE and A Level study. The vision is to create the first British Islamic university. The Hijazi Naqshbandis, under the leadership of their second-generation British Muslims hope to transcend narrow ethnic identities through the means of education and to look forward to the needs of the development of the Muslim community in Britain rather than the preservation of traditions and customs originating in the rural subcontinent. Their attempt to transform the landscape of the Abl-i Sunnat wa-jama'at blends innovation and tradition in that the college provides a centre for educating young Muslims whilst attracting pilgrims to the shrine in the grounds. However, the rhetoric of unity that is being raised in Britain by these leaders of subcontinent tariqas is still far from reality. Each group of murids remain obsessively loyal to their own shaykh and this can prevent them from cooperating in any project that benefits the whole community, especially if it originates in the vision or leadership of a rival tariqa. The ethnic and religious rivalries that dominate the organization of the Abl-i Sunnat wa-jama'at prevent the possibility of unity even amongst the Pakistaniorigin Muslims, let alone any kind of framework that brings together tariqas from other parts of the Muslim world. Several daunting problems need to be overcome in order for the Abl-i Sunnat wa-jama'at to successfully compete with the reform movements and ensure its survival at the heart of the British Muslim community. The primary challenges are (1) to win the loyalty of British-born Muslims who are alienated from the ethnic and religious divisions brought by their parents from the place of origin; (2) to develop a systematic doctrinal challenge based on Qur'an and Hadith that counteracts the teachings of the reform movements; (3) to develop an education system in Britain that rivals the Dar al-'ulums established by the reform movements; and (4) to develop organizational structures that compare with the tight-knit movements found amongst the reformers. Two organizations based around tariqas are beginning to address these issues with some success.

\section{The Haqqani Naqshbandis}

From 1973, Shaykh Muhammad Nazim 'Adil al-Haqqani an Naqshbandi began to visit Britain regularly from Cyprus. The Shaykh's first contact with Western European recruits to his tariqa was in Germany but by the 1990s he expanded successfully into 
North America. The Shaykh's undoubted charisma has allowed him to expand outside his ethnic base amongst the Turkish-Cypriot Muslim community in London and attract young British-born Pakistanis and converts from Western 'truth-seekers'.

In addition to the Shaykh's perceived spirituality embodying the traditional virtues of a Sufi mystic, when joining the Haqqani Naqshbandis, murids find themselves part of a transglobal network that to some extent transcends ethnic identity and links to a wider sense of Muslim identity that embraces the concept of a universal umma, so attractive to British-born younger generations. This embracing of a wider Muslim identity based on the legitimacy of the beliefs and practices of the Abl-i Sunnat wa-jama'at functions as an effective counteraction to the claims of the Wahhabi and Salafi-inspired movements who often promote themselves as an 'ethnically clean' universal Islam. Shaykh Nazim and his khalifa in the USA, Shaykh Muhammad Hisham Kabbani, are intensely aware of the need for more cooperation between the tariqas and in this context have organized a series of high-profile conferences in which international gatherings of shaykhs come together with their murids. Shaykh Kabbani has also written a seven-volume Encyclopaedia of Islamic Doctrine that provides an analysis and defence of the beliefs and practices of traditional Sunni Muslims and links them firmly to the Abl-i Sunnat wa-jama'at. ${ }^{25}$ The book functions as a scholarly and erudite criticism of Wahhabi and Salafi beliefs and accuses them of destroying Islamic consensus of belief and practice by inviting Muslims to follow a heretical innovation. Shaykh Kabbani has used the international conferences to announce the idea of jibad against these innovations in belief and practice. This has also served to divert the radicalism and activism found amongst the youth towards the traditional enemies of the tariqas as opposed to western political domination.

Kabbani has certainly developed a systematic doctrinal challenge based on Qur'an and Hadith that counteracts the teachings of the reform movements and has isolated the key divisions that cause conflict between the reform movements and the $\mathrm{Abl}-\mathrm{i}$ Sunnat wa-jama'at as:

1 The affirmation that Allah literally has a face, hands and a spatial direction;

2 The denial of consensus of the community (ijma') as a means to arrive at legislation;

3 Prohibiting the emulation of the judgements of the four imams who founded the schools of law;

4 Declaring Muslims who contradict Wahhabi or Salafi doctrine as disbelievers or even non-Muslims;

5 Prohibiting the use of the Prophet's name or the intervention of saints when petitioning Allah;

6 Prohibiting the use of tombs of prophets and saints;

7 Declaring Muslims who make a vow to someone else other than Allah at a grave to be non-Muslim;

8 Applying principles derived from narration of Hadith prior to those derived from reason. ${ }^{26}$

However, as yet the Haqqani Naqshbandis have not been able yet to address the issue of developing an education system in Britain or creating organizational structures 


\section{Learning the lessons from the neo-revivalist and Wabhabi movements}

that compare with the tight-knit movements found amongst the reformers. There are also problems with their attempts to transcend ethnicity. Although successful in the USA, the British situation is different in that the predominant subcontinent Muslim community remains very territorial. Attempts to organize conferences in British cities with large Muslim populations have been met with antagonism from local shaykbs and their murids who seem to regard Shaykh Nazim's incursions into their traditional strongholds as an intrusion. ${ }^{27}$

Although Shaykh Kabbani has been successful in marshalling the Abl-i Sunnat wa-jama'at identity in the USA through a campaign to promote the celebration of the Prophet's birthday as normative in the Muslim world, similar attempts to create a milad movement in Britain have met with antagonism. This may well be attributed to Kabbani's lack of knowledge of the British Muslim environment. In the USA, although Sufism is far better known outside Muslim circles where it has attracted significant converts, the Muslim migrant communities and the indigenous African-American Muslim community remain heavily influenced by Wahhabi and Salafi ideas. Because of this, celebration of Milad al-Nabi has not been generally accepted in the US Muslim population and a Milad movement campaign makes sense in the American context as a way of raising the Abl-i Sunnat wa-jama'at profile. However, in Britain the vast majority of Muslims celebrate Milad, often with conspicuous street processions. It is likely that the British shaykhs viewed Shaykh Kabbani's attempts to encourage Milad with some suspicion as it was already a fait accompli in the British context. Instead they perceived his motivations as an attempt to muscle in on their strongholds. This has resulted in some animosity and the declaration of a fatwa by a group of British shaykhs accusing the Haqqani Naqshabandis of corrupting Islamic belief and introducing innovation $\left(b^{\prime} d^{\prime} a\right){ }^{28}$

In addition to hostilities with the shaykhs of subcontinent origin, Kose has acknowledged that after Shaykh Nazim departs from Britain at the end of his traditional Ramadan visit, his various groups of followers return to their various ethnic subgroups and remain active only within their respective communities. ${ }^{29}$

Ethnic tensions remain in spite of the Shaykh's mission to promote the spiritual essence of Islam that he believes can unite a fragmented umma. Most of these tensions are a result of the continued presence of strong ethnic identity among Britain's Muslim population despite the rhetoric of common Muslim identity increasingly voiced amongst the British-born generations. The Shaykh's own ethnic identity, which commands the strong support of the Turkish-Cypriot Muslim population, functions to undermine attempts to penetrate the subcontinent communities in the name of $A b l-i$ Sunnat wa-jama'at unity.

\section{Idara Minhaj ul-Quran}

The Haqqani Naqshbandis maintain all the features of a traditional Sufi tariqa organized around the spirituality and personality of a charismatic shaykh, and, in many ways, demonstrate a 'waxing' of the Naqshbandiyya as defined by Pnina Werbner. ${ }^{30}$ However, the Idara Minhaj ul-Qur'an displays organizational features that bear a strong resemblance to the jama'at structures found in the twentieth-century revivalist 
movements. These borrowed structures appearing in a Sufi movement require a reassessment of the traditional organization of a tariqa and may provide a model for future movements that is more appealing to young Muslims. The Idara Minhaj ulQur'an has not only borrowed the organizational form but also some of the rhetoric of the twentieth-century Islamic revivalist movements, yet this has been achieved without compromising Abl-i Sunnat wa-jama'at belief and practice. On the contrary, the lessons learned from the more organized Islamic movements such as Jama'at-i Islami are being used to provide a platform for a rigorous defence of traditional Muslim views concerning the Prophet's significance and status within Islam and the role of the awliya. I have decided to label this new development arising out of the Qadiri tariqa as 'reformed Sufi organizations', and it may indicate a new development amongst the tariqas having to transform themselves as a result of external pressures coming from a rapidly changing Muslim world and the success of the reform movement's rhetoric and organizational structures to attract younger generations. If so, it is similar to the reforms that took place in the eighteenth and nineteenth centuries when tariqas such as the Naqshbandis and the Tijaniyya responded to Wahhabi criticisms and moved closer to orthodoxy, resulting in new organizational structures within Sufism.

The guiding light of the Idara Minhaj ul-Qur'an is Muhammad Tahir ul-Qadiri. The silsila produced by the movement shows a lineage back to Shaykh 'Abd al-Qadir al-Jilani through As-Sayyad Tahir Alauddin who migrated from Baghdad to Pakistan, but the emphasis of the movement is on their present shaykh and founder who is believed to be the mujaddid of this century who will reform Islam in the context of the contemporary world. Muhammad Tahir ul-Qadiri is a prolific writer and lecturer but his books reveal an interest in topics that are usually associated with revivalist leaders such as Maulana Maududi or Hasan al-Banna than a traditional shaykh of a Sufi tariqa. Foremost amongst these are the issues of an Islamic state and the right of $i t j i$ had which is denied by traditional 'ulama. In his writings on constitutional matters, Muhammad Tahir ul-Qadiri takes a position very close to Maulana Maududi, the founder of Jama'at-i Islami on the need for an Islamic state. He writes:

In an Islamic state Islam cannot be treated as a personal affair of an individual or a belief or faith of a particular group .... Thus there is a fundamental contrast between an Islamic state and a secular state. The authority of a secular state derives from the people themselves. Religion plays no obligatory role in its functioning. But the authority of an Islamic state derives from the Almighty Allah, the unitary, self-generated and self-sustaining sole creator of the universe, through the mediating agency of the Holy Prophet. Islam is basis of the polity in an Islamic state: it regulates both individual and state affairs. ${ }^{31}$

On the right to itjihad, Muhammad Tahir al-Qadiri is adamant that the rapid changes taking place in the world require dynamic solutions that can only be solved by direct interpretation of Qur'an and Sunna by a qualified mujaddid. He is critical of the conservative mentality of the "ulama who regard interpretative work that was conducted hundreds of years ago as still retaining its validity and authenticity and 


\section{Learning the lessons from the neo-revivalist and Wabhabi movements}

there is hardly any need to modify it or reshape it in the light of contemporary changes and exigencies'. ${ }^{32}$ He argues that the 'ulama have given more credence to figh than the teachings of Qur'an and Sunna. He is, however, also equally critical of Muslim modernists who rely too much on western solutions rather than Islamic ones and of Muslim governments who have compromised Islam.

Also similar to Maududi before him, Muhammad Tahir ul-Qadiri plays a more prominent role in the social and political arena of Pakistan than the traditional shaykh. He was educated at the University of Punjab, obtaining a PhD in Islamic Law as well as the traditional religious education following the Dars-e Nizami curriculum. He has been active in campaigning for an interest-free banking system in Pakistan and also took part in the campaign to denounce the Ahmadiyya as non-Muslims. The Idara Minhaj ul-Qur'an was established in the early 1980s and has already spread to over seventy countries. Like the movements that exemplify twentieth-century Islamic revival, it promotes a wide range of welfare activities. However, it is in organization that Idara Minhaj ul-Qur'an offers parallels and similarities to the revivalists that have been foremost in criticizing the Sufi tariqas.

Idara Minhaj ul-Qur'an perceives itself as a jihad movement to establish justice and equality based upon the tenets of Qur'an and Sunna. It is placed itself on a firm financial foundation through membership fees as well as donations. The movement is highly conscious of the position of women and youth and has established subsidiary organizations: the Minhaj ul-Qur'an Women's League and the Muslim Youth League. In Pakistan the youth movement is active in student politics through the Mustafavi Students' Movement. Internationally, both organizations are involved in setting up summer camps and providing vehicles for increasing literacy. This awareness to provide educational opportunities is manifested in the Minhaj University in Lahore which combines religious education with degrees in business administration and computer sciences. In addition, the movement indicates its position in regard to the need to combine traditional Islamic knowledge with the discoveries of modern science and technology so that Muslim society can progress materially as well as spiritually. In this regard, a number of affiliated organizations have been created such as COMET (Council of Muslim Engineers and Technologists).

The organizational forms developed by the Idara Minhaj ul-Qur'an owe a substantial debt to the work achieved in this arena by the jama'ats. Also akin to the Islamic revivalist movements is the emphasis on social and political activity and the assertion that Islam is a complete way of life that involves active participation from all Muslims to transform all areas of public and private human interaction. In the ideas of its founder can be seen the influence of Muhammad 'Abduh, the ideologue of the contemporary Salafi movement and Maulana Maududi, the great exponent of the conviction that an Islamic state is essential to practice Islam.

However, there are a number of crucial differences that place Idara Minhaj ul-Qur'an firmly within the camp of Abl-i Sunnat wa-jama'at. First and foremost, the organization see itself as a modern form of tariqa given both legitimacy and spiritual blessings by its claimed connection to 'Abd al-Qadir al-Jilani, the founder of the Qadiri tariqa. The training camps used to educate members into the spiritual values of Islam are based on tasawwuf. The syllabus includes dhikr (remembrance of Allah), tahajjud (optional night prayer), tilawat (recitation of the Qur'an) and istighfar (seeking Allah's 
forgiveness). The document written to proclaim the movement's aims states, 'to keep the soul intact, purify the mind and cleanse the heart of all ill morals and alike, we have to put pure, dynamic and intact Islamic Sufism of the early centuries back into action'. ${ }^{33}$ There is a certain irony in an organization arising out of traditional Sufism that claims to lead the recovery of the Muslim world from the decline of the least two-and-a-half centuries by changing both Muslim thought and action. To their opponents, the tariqas have held up to blame for the decline of the Muslim umma. Idara Minhaj ul-Qur'an uses both the rhetoric and the organizational forms of these same opponents whilst proclaiming the orthodoxy of the traditional doctrines and practices of the Abl-i Sunnat wa-jama'at, especially those in regard to the elevated status of the Prophet.

\section{Conclusion}

Recent developments suggest that a multitude of movements and mosques that represent traditional Islam, as embodied in the beliefs and practices of the Abl-i Sunnat wa-jama'at, are beginning to respond to the challenges presented to them by the reformist critique. There is no doubt that the efforts to promote their message amongst the young British-born Muslims anxious to define their identity through the discovery of a pure and universal Islam has borne dividends for the revivalist movements. Partly this has been achieved by a critique of Sufism as an aberrant superstition steeped in the practices and beliefs of subcontinent rural traditions and polluted by contact with Hinduism and partly by the attractions offered by close-knit superior organizational forms able to provide strong membership identities to young Muslims. The tariqas and mosques loyal to the Abl-i Sunnat wa-jama'at were often perceived as centres to maintain loyalties and relationships established in the country of origin and important to the older generation of migrants. They were also seen to be fragmented and obsessed with maintaining ancient feuds and divisions within the umma. The success of the revivalist critique can be measured by the degree to which young Muslims question shaykhs concerning 'aqida or matters of right belief.

However, a number of factors are contributing to the revival of the Abl-i Sunnat wa-jama'at in Britain. Prominent amongst these is the common desire of traditional Muslims to win the loyalty of their children in order to secure the future of their tradition. In order to achieve this they realize they have to match the efforts of the reform movements in the arena of education. Even more important is the need to counteract the criticisms made against traditional belief and practice and reclaim the position of Muslim orthodoxy based on Qur'an and Sunna. To this end the efforts of erudite shaykhs such as Muhammad Hisham Kabbani and Muhammad Tahir ul-Qadiri are essential. In addition, the tariqas are learning from their critics how to successfully use tracts, publications and, more recently, websites to promote their message. Ironically, the multi-national and multi-ethnic nature of the British Muslim community is also serving to overcome the revivalist critique of the Abl-i Sunnat wa-jama'at as Hindu-based superstition. Efforts by some tariqas, especially the Haqqani Naqshbandis, to promote conferences that bring together traditional Muslims from many parts of the world has undermined the criticism that Sufi beliefs and practices result from 


\section{Learning the lessons from the neo-revivalist and Wabhabi movements}

contact with non-Muslims. These conferences have enabled traditional Muslims to perceive the unity of belief and practice that extends across the Muslim world in spite of minor regional differences. In Britain, the shaykhs are beginning to successfully argue that it is their 'aqida which is the norm of Islam, and it is the Wahhabi/Salafi critique that is the aberration from traditional belief and practice. This discovery of unity of belief and practice is able to provide an antidote to the traditional divisions based on ethnic loyalties.

The new organizational forms found in Idara Minhaj ul-Qur'an, influenced by the revivalist movements themselves, are proving successful in attracting the younger generation and will provide a serious rival to the reformers. Above all, they will provide a more effective way of promoting the message untainted by accusations from the young which accuse the traditional tariqa structures as belonging to the past. There are still a number of problems that will bedevil attempts to proclaim a united Abl-i Sunnat wa-jama'at identity. These are to be found in traditional loyalties to individual shaykhs and ethnic identities that are used in a negative and competitive manner to proclaim superiority over others. However, there are increasing signs in Britain that the tariqas and the mosques loyal to the Abl-i Sunnat wa-jama'at are learning the lessons provided to them by their critics and are regaining the support of younger Muslims whilst at the same time undergoing their own revival, leading to new organizational forms as well as new manifestations of traditional forms.

The adoption of a political agenda by Idara Minhaj ul-Qur'an, often echoing the themes favoured by the reform movements, places them in direct competition with these forms of Islam, but provides in addition the spiritual and contemplative frameworks of Sufism to counteract alienation with western focus on consumerism. It is hard to ascertain whether the events of September 11 and its aftermath will increase recruitment to the reformist movements with their radical political agendas of Islamic statehood. On one hand, the increasing legendary status of Osama Bin Laden, the failure to resolve the Palestinian problem, the impending conflict between India and Pakistan over the sovereignty of Kashmir, and the perceived conflict between western and Muslim civilization may draw larger numbers of disaffected young Muslims to seek radical solutions. On the other hand, there may be a reaction to extremist rhetoric and a search for more moderate and traditional ways of expressing Islamic solidarity and piety. If the latter scenario is correct, organizations like Idara Minhaj ul-Qur'an stand to benefit at the expense of traditional tariqas as they can offer Muslim youth in Britain the organizational structures and rhetoric of dissent that they have been used to seeking amongst the Wahhabi and neo-Wahhabi revivalists. It is unlikely that the old traditional practices associated with rural 'folk' and 'popular' religion can survive beyond the first-generation migrants. Their children will seek to adapt Islamic belief and practice to the life in Britain; in this context reformed Sufi organizations will be able to compete with the revivalists of the Islamic movement by drawing upon traditional family allegiances to the Abl-i Sunna wajama'at but also by matching them in providing a form of organization more suited to the needs and aspirations of the British context. 


\section{Notes}

1 I have used the term 'traditional Islam' throughout the chapter to distinguish a brand of Islam that acknowledges 1400 years of tradition as authoritative alongside the teachings of Qur'an and Sunna and recognizes the contribution of Sufi spirituality, the legal interpretations of the "ulama and the four schools of law. This label of traditional Islam operates in opposition to neo-orthodoxies that deny the above and assert that Muslims have degenerated since the time of the first three generations.

2 Elsewhere I have posited a categorization of traditional Muslims in Britain as follows: (1) an inner circle of murids around a living shaykh based in a mosque; (2) an outer circle of murids who extend the tariqa to other centres of Muslim population across the country; (3) a further outer circle of non-initiated Muslims who are drawn to the mosque because of the status presence of the shaykh whose advice they seek on religious and non-religious matters; (4) another outer circle that use the mosque to visit the shaykh because of his access to karamat, and that will looking for traditional sacred solutions to life problems and crises; (5) an outermost circle that uses the mosque because it is local to their homes but does not preach a Wahhabi or Salafi orthodoxy (Geaves 2000).

3 Muslims had been coming to Britain since the nineteenth century as merchant seamen. Large numbers of Yemenis and Somalis were recruited on the opening of the Suez Canal in 1869. The Yemeni sailors arrived in the seaports of Cardiff, Liverpool, South Shields and Hull. The seaport settlements in Cardiff and Tyneside were organized around the inspiration of Shaykh 'Abdullah 'Ali al-Hakimi of the 'Alawi Shadhili tariqa who arrived in Britain in 1936. For a detailed history of the Yemeni presence in Britain see Fred Halliday, (1992).

4 R. A. Geaves, (1996a), pp. 159-162.

5 Usha Sanyal (1996) in her excellent study Devotional Islam and Politics in British India refers to the activities of Ahmad Riza Khan as a movement that defined itself against the 'other' which consisted of Indian Muslim variations of Wahhabi ideas. Ahmad Riza Khan's genius was to posit that following the Prophet's path with the help of saintly intermediaries often through shrine-centred devotion was a conscious choice to follow traditional Islam as practised by the majority of Muslims throughout the worldwide umma rather than blind attachment to ancient customs located in the subcontinent and deriving from contact with Hinduism (Sanyal, 1996, pp. 5-6).

6 Stephen Barton, (1986), p. 102.

7 R. A. Geaves, (2000), pp. 87-90.

8 Maulana Maududi created the Jama'at-i Islami in 1941 with the idea of training committed members who would work towards the foundation of an Islamic state in the subcontinent. The ideal was to create a state firmly based upon the shari'a that would exemplify the teachings of an orthodox Islam to both other Muslim nations and the nonMuslim world. The movement has been active in Pakistani politics, creating trained cells of activists to work towards achieving social and political leadership. Although active amongst the mujabidin organizations to liberate Afghanistan from Russian domination, other organizations created in Pakistan at that time have become far more radical in their methods used to achieve their goals. Jama'at-i Islami ideals are represented in Britain by four organizations: the UK Islamic Mission, Young Muslims UK, the Islamic Foundation and the Muslim Educational Trust (Geaves 1996a, pp. 185-188).

9 Sayyid Mahboob Rizvi, (1980), p. 136.

10 I have decided to use the term 'Islamic Movement' even though the existence of a phenomenon which can be defined as a single movement, arising throughout the Muslim world, has to be demonstrated. Many of the Muslims that I have interviewed use the term to indicate their allegiance. The term is in everyday use, especially in the media. Dr Kalim Siddiqi has acknowledged that the term is of recent origin in Muslim history. He suggested that the Arabic equivalent, al-haraka al-islamiyya, dates back to some time after the founding of al-Ikhwan al-Muslimun by Hasan al-Banna in Egypt in 1928. He believed 


\section{Learning the lessons from the neo-revivalist and Wabhabi movements}

that both al-Ikhwan al-Muslimun and Jama'at-i Islami began to use the term in the 1960s to differentiate themselves from nationalist and secular Muslim parties such as the Muslim League in Pakistan and the Wafd in Egypt (K. Siddiqi, 1995, p. 6). The important point here is that to many Muslims the attainment of an independent state was a religious as well as political event. There are those that take the ideal of an Islamic state far more literally and much more seriously, who believe that the nation has been created for the sole purpose of showing the world a model Islamic state that is based upon the sovereignty of Allah rather than the secular ideal of the sovereignty of the people. They argue that in Islam there is no distinction between the spiritual and the temporal realm: the matter of worldly life is not left to the discretion of human beings but there is a clearly defined path based on revelation and God has commissioned the state to enforce these commands. Kalim Siddiqi argued that that it is possible to view the Islamic Movement 'as an ad hoc arrangement in a situation when no Islamic state existed' (ibid.). Siddiqi has attempted to define the Islamic Movement as a global phenomenon which 'consists of all those Muslims, who, through individual or organized effort of whatever nature sanctioned by Islam, are trying to contribute towards the eventual establishment of one or more Islamic states under a khalifalimam anywhere in the world' (Ibid., p. 7).

11 Geaves (2000), p.57.

12 Hizb ut-Tahrir was founded in 1953 in Al-Quds (Jerusalem) by Taqiuddin al-Nabhani. According to its own literature, the organization exists to revive the umma from a state of serious decline and to remove all traces of ideas, organizational structures and political formations that have originated from the West (Kufr) rather than from the Qur'an and Sunna. The final objective is the restoration of the Khilafah rather than the series of independent Muslim states that exist in the present time. It is this that marks them out from organizations such as Jama'at-Islami which seek to overthrow secular Muslim states and replace them with Islamic governments who firmly abide by the shari'a. In one vision there is a series of independent Islamic states to replace the existing Muslim nation states, in the other vision, nation states disappear to be replaced by a khilafah. Hizb ut-Tahrir defines itself as a political party whose ideology is Islam and which works with the Muslim umma to restore the khilafah. (http://www.hizb-ut-tahrir.org/english/definition/ messages.htm, p. 1.)

13 Ibid., p. 58.

14 Carl Ernst, (1997), p. 200.

15 Ibid., p. 212.

16 J. Trimingham, (1971).

17 George Joffe, (1998), p. 66.

18 Gellner distinguishes between rural Muslims, whose Islam relies on a multiplicity of ritual and mystical practices and devotion to charismatic personalities, and urban Muslims, who stress strict monotheism, Puritanism and scriptural revelation (Gellner 1968, pp. 130-136).

19 R. A. Geaves, (1999), p. 366.

20 For a detailed analysis of the impact of the arrival of pirs and shaykhs in Britain see R. A. Geaves, (1996b).

21 J. Nielsen, (1992), p. 159.

22 Geaves (2000), op.cit., p. 97.

23 Ibid., pp. 90-94.

24 See Philip Lewis, (1994), p. 81. Lewis's book provides a detailed account of the activities of Pir Marouf and outlines the problems that he has faced in trying to promote the Abl-i Sunnat wa-jama'at in the UK.

25 Hisham Kabbani, (1998).

26 Kabbani (1998), Vol. 1, pp. 196-197.

27 Geaves (2000), p. 154

28 Apparently the disagreement is over the claims of Haqqani Naqshbandi followers that Shaykh Nazim can intercede for them on the Day of Judgement. This is in opposition to 
traditional Muslim doctrine that allocates such a privileged role only to Muhammad, and sometimes extended to other prophets for non-Muslim communities.

29 Ali Kose, (1996), p.158.

30 Pnina Werbner defines a constant historical process of 'waxing' and 'waning' amongst the local offshoots within a broadly encompassing tariqa. She suggests that new cults appear 'energized through the emergence of a charismatic saint' (p. 28) which revitalize the tariqa (Pnina Werbner, 1990b).

31 Muhammad Tahir Ul-Qadri, (1985a), pp. 5-6.

32 Muhammad Tahir Ul-Qadri, (1985b), pp. 25-28.

33 Document entitled Tehreek Minhaj ul-Qur'an, p. 6 


\title{
9 Popular Islam in northern Pakistan and its reconstruction in urban Britain
}

\author{
Roger Ballard
}

An awareness of the presence of Allah pervades the lives of rural Punjabi Muslims. In addition to the way in which invocations such as bismillah, mash'allah, insh'allah and shukr hamdul'illah pepper every conversation, everyone's personal name articulates one or other of the ninety-nine qualities of Allah. Although there can be no doubt whatsoever that all those who behave in this way are followers of Islam, just how can we best specify what 'being a Muslim' actually entails in this specific local context?

\section{Two dimensions of Islam}

Although Punjabi Muslims experience their faith as a seamless whole, closer examination of the actual content of rural practice reveals that popular interpretations of the Prophet's Sunna are grounded in two analytically distinguishable, although closely interwoven, components. The logical foundations of this distinction - which is in no way unique to the Punjab - are easy enough to specify. Starting from the proposition that Allah created but one al-insan al-kamil, the Prophet Muhammad, as an exemplary vehicle through which to transmit his ${ }^{1}$ expectations to the world which he had created, the Prophet's status as an exemplar is held to have two complementary dimensions. On the one hand the Prophet's behaviour, as observed by his associates, is regarded as providing a template of behavioural righteousness around which Muslims should consequently seek to organize every aspect of their own everyday behaviour. On the other hand the Prophet's spiritual capacities - whose strength and sophistication were of such intensity that he was capable of being vouchsafed the Qur'an - are seen as providing an equally inspirational set of spiritual signposts. Hence whilst the Prophet's behavioural Sunna is a necessary starting point for all Muslims, those who are prepared to delve deeper by exploring the more spiritual dimensions of that Sunna can begin to gain access to levels of gnostic experience which are similar in kind, although by definition never so intense, as those experienced by Allah's al-insan al-kamil.

Although analytically distinguishable, these two dimensions of Islam are comprehensively interrelated in practice. Just as neither is fully meaningful in the absence of the other, so neither can be reduced to the other. In the absence of respect for the organizational and behavioural imperatives which underpin Allah's created order, gnostic understanding of its hidden significance is inaccessible; and in the absence of at least 
some degree of awareness of that gnostic dimension, behavioural righteousness - no matter how exemplary - is reduced to an empty and hypocritical gesture. Hence mere external conformity with formal principles of the shari $a$, especially when deployed to justify the self-interested enjoyment of wealth and power, is popularly regarded as the very antithesis of what Islam is all about. For everyday believers the true test of commitment to Allah is not so much behavioural conformity, but rather of what goes on 'within the heart'.

The resulting distinction of the worldly sphere of zabir and the internal, and hence 'hidden' sphere of batin can usefully be mapped onto a socio-political disjunction which runs through every Islamic society: that between the world of the "ulama, the scholarly guardians of the behavioural orthodoxy which is spelled out in such detail in the shari' $a$, and the world of the shaykh and pir, the charismatic articulators of the spiritual and gnostic experience. Whilst both dimensions are equally Islamic, since both offer authoritative interpretations of how the Prophet's Sunna can best be followed, the road-maps which each sets out differ radically. Whilst 'ulama are lawyers who ground their advice in their scholarly knowledge of the Qur'an, the Hadith and the shari'a, shaykhs and pirs provide inspiration and advice for their followers on the basis of the experiential authority which they have gained as a result of intensity of their own personal spiritual practice.

Yet despite the depth of these differences, and the bitter arguments which can so easily erupt between those who interpret the implications of the Prophet's Sunna in contradictory ways, these two tracks are far from being mutually exclusive, most especially in terms of popular practice. Nevertheless the balance between the two can vary so enormously as between differing contexts. Hence, for example, it is far from unusual for "ulama who ground their commitment to meticulous behavioural orthodoxy in close study of the prescriptions of the shari'a to become members of a Sufi silsila - although it is invariably one which fosters a thoroughly sober path to spiritual awareness, and in which gnostic passion is never allowed to compromise behavioural correctness. Meanwhile, at the other end of the spectrum, Sufi masters whose personal path towards gnosis is much more ecstatic in character regularly insist that their less spiritually sophisticated followers should in normal circumstances take a far less transgressive approach to the limitations of external conformity.

Why, though, should transgressive activities and experiences be a necessary component of spiritual progress? From a Sufi perspective the answer is quite straightforward. Not only does gnostic experience 'shake up' one's very being, but anyone who seeks to gain access to such experience must allow themselves to be 'shaken up' before they can begin to step along the path towards it. Strong measures are therefore required to break through the veils of everyday (mis)apprehension which conceal the hidden significance of the existent world. It follows that those who wish to step beyond the external zabiri dimensions of the Prophet's Sunna such that they can begin to experience its more hidden spiritual possibilities face an extremely challenging task. The results are plain to see. Extreme forms of ascetic discipline assisted where appropriate by such intoxicating involvement in the rhythm of poetry, music and dance - are a routine component of Sufi practice in all parts of the Islamic world. 


\section{Popular Islam in northern Pakistan and its reconstruction in urban Britain}

Providing a means whereby all sense of personal egotism can be swept away, ecstatic experiences which are ever more overwhelming in their impact provide convenient stepping stones towards fana and baqa, such that the devotee can ultimately begin to gain access to the bitter-sweet experience of "ishq. Popular allegory represents this process in graphic terms by suggesting that just as ecstatic moths lose control of their very being as they dance ever more passionately around the flame which is about to absorb them, so the stern behavioural prescriptions of the "ulama fade into ever greater insignificance the further the Sufi adept is pulled ever further down the path towards the irresistible illumination of - and extinction within - gnostic experience. The pursuit of this goal may be as difficult as it is dangerous, but there can be no dispute about the basic principle: that the experience of gnosis reduces all other priorities to insignificance.

Nor are such matters solely of theological and philosophical concern. As Ibn Khaldun argued long ago, the interaction between these two complementary streams of thought and behaviour have long played a key role in the dynamics of the Islamic social order. Indeed with his model in mind it would be quite be feasible to set about placing all Islamic religious practices, as well as all the ritual specialists who oversee them, along a continuum running between these two extremes. However, that is not a task which I intend to undertake here. Instead my aim in this context is simply to use this distinction as the foundation of a conceptual framework within which to make sense of the wide range of ideas, beliefs, and practices routinely used by the rural Muslims living in the Potohar region of Pakistani Punjab, as well as by those deployed by their kinsfolk who have by now settled in the UK.

As such, my viewpoint is firmly 'from below'. Whilst those with whose beliefs and practices I am concerned here routinely interact with Islamic 'specialists' of one kind or another - whether in the form of the maulwis who lead prayers in local mosques, or of the pirs to whom they turn in times of trouble - I have certainly not turned to such specialists as my primary source of entry into the logic of popular understandings as to just what it means to be a Muslim in rural Punjab. To be sure, the Islam with which I am concerned has evolved in the course of many generations of creative interchange between popular ideas and understandings and the teaching and preaching of such specialists; but if the interchange has indeed long been mutual, the automatic prioritization of such expert prescriptions can be deeply misleading, for it all too easily leads to the presentation of popular practice as a pale and deviant shadow. It is with precisely with such considerations in mind that I have taken everyday popular conceptualizations, rather than formally prepared texts, as my analytical starting point. $^{2}$

\section{Being a Muslim}

Being a Muslim is a normative experience in contemporary Pakistan: with the exception of a small minority of converts to Christianity and an even smaller number of Ahmadiyyas (followers of what the Pakistani State has relatively recently declared to be the anti-Islamic teachings of Mirza Ghulam Ahmad), everyone else whom one encounters in Pakistan is presumptively a Muslim, no matter how he or she may 
behave. To be sure, those who never perform namaz, nor even visit the Mosque at $I d$, let alone those who consume forbidden substances such as pork and alcohol, attract adverse critical comment. However, only the bigoted few would ever suggest that such behaviour is so deviant as to place such backsliders outside the fold of Islam. Other than the Prophet himself, who can claim perfection?

Nevertheless it would be quite wrong to assume that nothing is sacred. Whilst deviance from behavioural expectations associated with Islam may attract critical comments, any utterance which casts doubt on Allah's cosmic capabilities, precipitates a much more active response. Even if the remark was not deliberately intended, it will nevertheless swiftly elicit horrified - but prophylactic - cries of Tawbah, tawbab! Likewise even those whose personal outlook may appear to be comprehensively secular regularly qualify their plans for future activity with the cautionary epithet insh'al$l a b$; in the same vein any suggestion - no matter how inadvertent - which appears to predict the future course of life and death amongst one's nearest and dearest invariably attracts even stronger precautionary invocations. The reason for so doing are quite clear: failure to acknowledge the inscrutable powers of the Almighty puts one in danger of being reminded just who is really in charge. Similarly, any utterance which casts doubt on the honour of the Prophet (or of his immediate companions) is regarded as profoundly sacrilegious - as Salman Rushdie learned to his cost.

Whilst Rushdie touched a raw nerve, the specific character of his offence is worth noting. It was certainly not one of blasphemy in the Christian sense. For Muslims, the Prophet is emphatically not divine: he is human. Nor did Rushdie contravene the provisions of the shari ${ }^{\prime} a$ in any direct sense. Instead, popular objections focused on his unashamed mockery of the core component of Islam's spiritual and cosmological vision: the status of the Prophet as al-insan al-kamil, and his unique relationship with the Creator.

It is above all through an appreciation of the significance the relationship between the Creator and his creation that Islam pervades lives of rural Punjabis. As the inscrutable source of all existence, Allah Mian is regarded as being as immanent as he is transcendent, and is consequently held to be present and active in every nook and cranny of His created universe. It is therefore incumbent on all created beings, and most especially of insan (mankind), to pay homage to the comprehensiveness of the Creator's powers, as the phrases cited at the outset of this chapter serve to underline, since everyday discourse ensures that verbal acknowledgement of those powers is constantly on everyone's lips. Not only does everyone thereby give thanks for that which has been delivered to them, but they also seek Allah's blessings before embarking on any enterprise. Failure to observe such basic courtesies invites the prospect of being taught a severe lesson about the consequences of contempt.

Yet however respectful Muslims may be of Allah's awesome powers, personal mishaps still occur. That comes as no surprise. If Allah's will is entirely inscrutable, mere humans can never hope to comprehend the cosmologically oriented purposes of the Almighty. Hence whilst all events within the created world have a purpose, just what those purposes are will by definition be well beyond the purview of humankind. Hence believers must accept rather than query whatever outcomes the Creator may have prescribed for them. No matter harsh all this may seem to those schooled in 


\section{Popular Islam in northern Pakistan and its reconstruction in urban Britain}

more rationalist modes of thought, it can nevertheless bring positive reassurance to those who take such a cosmology for granted. Hence, for example, the grieving mother of a still-born born child put a positive gloss on her distress from the thought that Allah Mian must have recalled her dead baby's soul as a result of finding another yet more significant purpose his tiny being to fulfil. Such an acceptance of qismat is not, however, a recipe for fatalism. Whilst effort, mainat, cannot in itself guarantee success (Allah alone can do that), those who make no effort to make the most of whatever has fallen to their lot stand much less chance of receiving Allah's blessings than those who actively seek to help themselves. Even so, nothing is certain: some believers find themselves burdened, like Job, with endless misfortune. But just as the biblical story insists, such an uncalled-for plight can positively reconstrued as a test of faith.

\section{Mazars, Pirs and intercession}

Yet acquiescence is by no means the end of the matter: popular belief provides many further explanations of the causes of unexpected misfortune, and an equally diverse range of strategies by means of which relief can be sought from its consequences. Hence those who find themselves suffering from Job-like misfortune do have a further option: a direct appeal for mercy to the Almighty. But how and where should such an appeal to be lodged? Given Allah Mian's transcendence, it is wholly infeasible for everyday believers to make such an appeal on their own account. Not only do they lack capacity to frame such a petition in appropriate terms, but their spiritual status is manifestly wholly insufficient for them to be able to gain direct access to the Throne. So just as one engages an advocate to present one's case in a court of law, so one should likewise seek out an intercessor with a right of audience in the highest Court of all.

The first step in so doing is to offer prayers at the shrine (and tomb) of a deceased pir, beseeching him to intercede with the Merciful One on the supplicant's behalf. With the pir's recommendation attached, such pleas have a far better prospect of being heard - and answered. These practices have a straightforward theological justification. Since the pir in his tomb is present on an earthly plane, he is accessible to ordinary believers in a way which the Transcendent One is not; but precisely because the pir has achieved his 'urs (union with his Beloved, the ultimate goal of Sufi gnostic experience), he is in far closer communion with Allah than a living person could ever hope to be. Hence his capacity to act as an intercessor.

In a Punjabi context this understanding of saintly intercession is by no means unique to the Islamic tradition. Hindu Sadhus and Sikh Sants are regarded as having a communicative relationship with the Ultimate that is similar to Muslim pirs. As a result all those who have achieved intense gnostic insight attract the title of Baba. In much the same vein their shrines - mazars and dargahs for pirs, sthans and samadhs for Yogis, and gurudwaras for Sants - are held to open similarly structured intercessory doors to the Ultimate. Such shrines are a commonplace feature of the Punjabi rural landscape.

Whilst most such shrines are more or less clearly constituted as Muslim, Sikh, or Hindu, closer inspection of their sacred symbolism invariably reveals a significant degree of hybridity: indeed this condition of hybridity is sometimes so great as to 
render it impossible to assign the shrine to any one of these traditions. ${ }^{3}$ This lack of boundedness is further underlined when one explores the qaumic background of the pilgrims seeking intercessionary assistance from such shrines, for it soon becomes clear that in the Punjab - as in most of the rest of South Asia - supplicants in no way feel restricted to seeking assistance from shrines associated with a specific panthic tradition. This was brought forcibly to my attention when conducting fieldwork recently in the Jullundur Doab. Although virtually all the indigenous Muslim population of the Doab fled west to Pakistan over half a century ago, careful inspection revealed that a significant number of rural shrines were those of pirs, since the shrouds covering such well-tended tombs and the flags which flew over them were green the colour of Islam. ${ }^{4}$ The largest of these shrines became hives of activity on each juma'raat (the evening preceding the Islamic day of prayer on Friday) and positively burst with energy at their annual 'urs of the saintly pir entombed within it - even though the local Muslim population had long since disappeared. It follows that virtually all those making use of the shrine belonged to local Hindu or Sikh families.

From a popular Punjabi perspective, there is nothing contradictory about such behaviour. The pilgrims who flock to such dargahs, sthans and gurudwaras - no matter whether they identify themselves as Muslims or Hindus or Sikhs - all do so with a similar qismatic purpose: to beseech its saintly founder to intercede with the Ultimate on their behalf. Shrines of all kinds - whether they be one of the innumerable memorials to local saints found outside every village in rural Punjab, or the tombs of major historical figures such as Datta Ganj Baksh in Lahore, Baba Farid Shakarganj in Pak Pattan, or Golra Sharif near Rawalpindi - consequently remain the focus of intense devotional activity. At each such Durbar, pilgrims direct their pleas towards the pir who lies within with passionate intensity; and in witness of their silent vows to bring offerings to the shrine should their pleas be heard, pilgrims tie strips of cloth in the branches of nearby trees as an overt reminder of both their plea and pledge. It would be grossly discourteous - and indeed asking for trouble - to fail to fulfil such a pledge. Hence innumerable strips of cloth flutter from the branches of trees surrounding popular shrines, whilst many of the pilgrims making return visits bring expensive offerings in thanks for the blessings they have received.

Living pirs, who are routinely regarded as having acquired occult powers as a result of the intensity of their spiritual commitments, are likewise much consulted by those in distress. In the first place they are credited with the capacity to diagnose the causative source of any given affliction, and secondly with the ability provide a remedy with which to hold that precipitating cause at bay. In making their diagnoses, rural pirs utilize an explanatory framework which includes - whilst also looking far beyond - the model of Allah's over-arching powers which has so far been outlined. Plugging into popular cosmological understandings at a rather less theologically rarefied level, pirs most usually suggest that the afflictions complained of are either a consequence of unconscious jealousy, nazar, or of the activities of malevolent kinsfolk who have used jadoo or tuna to harm the unfortunate victim, or the outcome of the victim having been possessed from within by a jinn, a bbut, a pret or a churail - malevolent spirits who have been banished to the fringes of the social order. Once diagnosis has been achieved, pirs most usually prepare a ta'wiz (an amulet containing Qur'anic 
verses) with which to counter the malevolent influences so detected, or in more extreme cases conduct an exorcism in which the possessing spirit is first confronted, then placated, and finally expunged from its unfortunate victim. ${ }^{5}$

Living pirs, no less than the shrines of their long-dead predecessors, attract a huge clientele. When faced with severe and apparently irremediable difficulties few families fail to explore the utility of such remedies as they make increasingly desperate efforts to resolve their problems. Lack of success is no deterrent. If any given source of occult assistance fails to precipitate the desired result, it is easy enough to conclude either that their own supplicatory commitment was too weak, or that the source consulted had insufficient intercessory powers, or that the condition for which a remedy was sought fell outside its specialist competence. Hence the hunt continues, such that families make ever more distant pilgrimages (and personal sacrifices) in an effort find a pir with the capacity to remedy their distress.

\section{Popular practice and its critics: are Punjabi Muslims really Muslims?}

In my experience very few Punjabis - no matter how 'orthodox' their religious commitment may be, and no matter whether they are Hindus, Sikhs or Muslims fail to explore such remedies when faced with severe and otherwise irresolvable personal difficulties. Nevertheless public criticism of such practices is now increasingly widespread, in the first place from Maulwis, who regularly argue that 'shrine-worship' - and most especially the belief that pirs can facilitate intercessory communications with Allah - constitutes a polytheistic deviation from Islam's commitment to the absolute unity and uniqueness of God. In the second, secularly minded urban intellectuals are equally critical of such 'superstitious' practices, arguing that they simply provide a convenient means through which to exploit the credulous and irrational beliefs of the uneducated and illiterate masses. Finally, both streams of criticism are brought together by revivalist groups such as the Jama'at-i Islami, who not only argue that such practices are as much a manifestation of shirk (polytheism), but also that they are an unfortunate leftover from the Punjab's superstitious Hindu past.

Within this conspectus traditionalists and modernists have found plenty of opportunities to develop common ground. Arguing that such practices can find no justification in either the Qur'an or the shari' $a$, they insist that all those who credit pirs with occult powers, and especially those turn away from mosques with their Mecca-oriented mibrabs to offer prayers to a shrine tomb are committing wholly unacceptable shirk. This critique has radical consequences. If sound, it follows that a large part of the everyday practices of Punjabi Muslims, as well as the ideas and ideologies which underpin them, are not Muslim at all, but relics of their benighted past. Hence if Muslims are to be true to the essence of their faith, there is an urgent need for reform: only by implementing a thorough process of 'Islamization' can the last remnants of Hindu polytheism finally be extirpated from popular practice, so enabling all believers to enfold themselves at long last into the universalistic umma of pure Qur'anic Islam. ${ }^{6}$ 


\section{Islam as prescription and Islam as practice}

Many pious Punjabi Muslims find such arguments extremely bewildering. Can it really be that their everyday practice is really so comprehensively misguided as to require them to undergo a comprehensive programme of religious re-education? Such demands seem to be as unnecessary as they are insulting. As Sunni Muslims, their everyday practices represent their best efforts to emulate the Prophet's Sunna. To be sure, their efforts are imperfect: how could it be otherwise? But to suggest that they are so misguided as to require comprehensive 'Islamization' seems absurd. Mosques are just as much a feature of the rural landscape as are shrines. Each attracts a substantial (male) congregation for Friday prayers, and even more on feast-days such as 'Id. Nor is the saying of namaz limited solely to the mosque: men, and even more so women, regularly perform namaz at home in response to the azan which their Maulvi calls five times a day. Likewise the fast is regularly kept during Ramzan, meat is only eaten if it is halal, and the Maulwi is regularly called in to officiate at the life-crisis rituals associated with birth, marriage and death. Hence it is only a dimension of popular belief and practice - almost exclusively that associated with pirs and shrines - of which the neo-revivalists are so critical.

This state of affairs - which is by no means unique to the Punjab ${ }^{7}$ - throws up a major challenge for all students of Islam. Just what should we mean by Islam, and how should we set about identifying it? Should we prioritize the prescriptive injunctions generated by generations of legalistic analysis of the Qur'an and the Hadith, which both modernistic neo-revivalists and the more traditionalist Maulwis insist is the only way forward? Or should we, to the contrary, focus on the ideas and practices which generations of believers have developed in the course of their efforts to access the illumination available with the Prophet's Sunna?

For those seeking clear-cut guidance on such matters a textualist approach appears at first sight to have much to recommend it. Firstly, careful analysis of authoritative texts should at least in principle provide a clear set of prescriptive guidelines as to what is, and what is not, legitimately Islamic - always provided that agreement can be reached over just how the texts in question should be read and interpreted. ${ }^{8}$ Secondly, such a textually derived approach is congruent with classical European approaches to scholarship in the field of religious studies. And last but not least, the construction of a clearly defined and behaviourally prescriptive sense of what 'being a Muslim' entails provides a highly effective foundation around which to erect a powerful sense of socio-political solidarity amongst those who so identify themselves. For those with political objectives in mind, the more that Muslims can thereby consolidate themselves within a supra-national umma, the better equipped they will be to defend their collective interests.

Be that as it may, the consequence of adopting a purely textualist approach to the study of religion has several glaring deficiencies. Besides suggesting that all interpretations (and the practices derived from them) which deviate from what has come to be identified as the prescribed ideal should simply be dismissed as misguided, it also implies that all arguments about the legitimacy of such prescribed interpretations can only be properly resolved by yet more detailed textual analysis. If so, it follows 
that the empirical study of Islam as practised is rendered wholly unnecessary: the study of texts becomes the sole legitimate source of religious illumination.

If, however, one treats Islam as a living religion which deserves - and indeed demands - detailed empirical exploration, just what sort of theoretical and analytical framework is best deployed if one is to do justice to everyday believers' own expressions of their faith? From their perspective any suggestion that their everyday beliefs and practices are mistaken, contradictory and above all 'un-Islamic' is quite absurd. They also have a ready response to such critiques: that it is their neo-revivalist critics who are mistaken, since their constant concern with behavioural conformity overlooks the key feature of living Islam: that it is above all the outcome of heart-felt experience of the immanent presence of Allah in all facets of the created world.

But if this is so, how can and should such a faith-based analytical perspective best be pursued? Must the study of 'popular religion' in this sense be placed in an entirely different category from Islamic orthodoxy? Or is there, to the contrary, a vision of Islam which is at much at ease with the spiritual and emotional vitality of popular practice as it is with the behavioural prescriptions of the legalists? To put it another way, are the ideas and practices to which contemporary revivalists take such exception really as deviant as their rhetoric suggests, or are they better regarded as the manifestation a stream of spiritual experience whose origins can be traced right back to the Prophet himself?

In a volume such as this, that question has a very obvious answer: Sufi spiritualism is as intrinsic to the Islamic tradition as is the legalism of the 'ulama. Nevertheless simply to describe popular practice as 'Sufi' is seriously misleading, not least because that not a term which most Pakistani Muslims would normally use to identify either themselves or their practices. As far they are concerned the term is best reserved for use as a means of identifying those spiritual adepts who are wholeheartedly committed to intense levels of spiritual practice. Hence in their view those buried beneath shrines are certainly Sufis; so too are living pirs, as well as their most dedicated followers. However, in no way are Sufis and their practices viewed as external to Islam: on the contrary, such figures are regarded as amongst the best of its exemplars. Nor do everyday rural Muslims see themselves as doing anything unusual - let alone contradictory - in offering prayers in shrines as well as mosques: all such activities are viewed as equally important components of a single Islamic whole.

However, in contemporary Pakistan, neo-revivalists - the majority of whom are associated with the Deobandi movement ${ }^{9}$ - are making ever-more active efforts to discredit the 'Sufi' dimensions of popular practice. And if only because the two schools of thought have been in vigorous contest with one another in the plains of Hindustan to the east of Delhi for well over a century, the activists who begun to defend popular forms of Punjabi belief and practice of which the Deobandis are so critical are frequently described as Barelwi. ${ }^{10}$ But whilst that appellation is now coming into increasingly widespread use, my own experience suggests that the great majority of those to whom the label is applied have very little knowledge of the teachings of Ahmad Riza Khan, or an active connection with the Abl-i-Sunnat which he founded. To be sure, there is a great deal of congruence between the ideological framework which underpins Reza Khan's teachings and that around which everyday 
practice in rural Punjab is constructed; but if the second is not a direct consequence of the first - and there is little evidence to support that view - it is analytically misleading to use the term 'Barelwi' to identify the roots of popular Islamic practice in rural Punjab.

\section{The rise of Islam in the Punjab: the role of the Chishtiyya}

If we are to set contemporary Islamic practice in the Punjab within an appropriate historical context, little is to be gained by confining our attention to movements which erupted in the late nineteenth century, and which only began to have a significant impact in the Punjab following Pakistan's partition from India in 1947. Islam's local roots in the Punjab have a very much longer history. As Eaton ${ }^{11}$ has shown in very considerable detail, the slow conversion of the region's population was largely the outcome of the proselytizing efforts of members of the Chishtiyya silsila, and most especially to the decision of Shaykh Farid al-Din Ganj-i-Shakar (d. 1265 C.E.) to set up a khanaqah at Pakpattan on the banks of the river Ravi some distance south of Lahore early in the thirteenth century. Prior to this, Muslims were a tiny minority amongst the population at large. To be sure, military adventurers from Afghanistan and Central Asia had by then gained political control of the greater part of northern India, but at this early stage Islam was viewed as the cult of the conquerors, no less by the new rulers than by their subjects. In South Asia, no less than the remainder of the Islamic world, conversion of the broad mass of the population followed much more slowly in processes which often took several centuries to complete.

Yet before we can explore just how these processes worked out in a Punjabi context, we must first take cognizance of the region's religious character prior to the irruption of Islam. Whilst the Punjab may have been the birthplace of Indic civilization during the second millennium before the birth of Christ, the centre of gravity of the emergent Hindu tradition slipped steadily south westwards in the centuries that followed. Hence from 300 BCE onwards religious activity in the Punjab was much more Buddhist than Hindu in character. Indeed from the beginning of the Christian era right through to the period immediately prior to the arrival of Islam, the Punjab was better understood as the most easterly component of a Buddhist civilization which stretched west and north through Afghanistan to Bactria than of a Hindu civilization which was by then rapidly expanding southwards through the Deccan. Although the Punjab's Buddhist tradition does not appear (at least on the face of things) to have survived the rise of Islam, it is known to have had close links with the Tibetan form of Mahayana, and as such to be strongly Tantric and Sahajiya in character; ${ }^{12}$ and as Das Gupta has shown, the cosmological and gnostic assumptions around which Hindu and Buddhist forms of Sahajiya practice were constructed were extremely similar. Hence there are good reasons for suggesting that prior to their conversion Islam the great majority of Punjabis were primarily inspired by mystically and ecstatically oriented Sahajiya cults of one kind or another, as opposed to the more hierarchical and ritually oriented approach of the Brahminical tradition.

However, the process of conversion to Islam was far from instant: rather, it took place over the course of several generations. ${ }^{13}$ Like most of the other Sufi silsila which 
played a major role in the conversion of the inhabitants of Hindustan to Islam, ${ }^{14}$ the Chishtiyya movement emerged in the cities of Balkh and Samarkand - themselves still in the midst of conversion to Islam - in the eleventh century CE. Hence it was from central Asia that Gharib Nawaz set off on a life of pilgrimage and preaching which took him to Baghdad and Damascus before settling in the town of Ajmer, deep in the Rajasthan desert on the road between Delhi and Multan, where he died in 1236 CE. However, his spiritual teachings brought him immense fame and a new title, Shaykh Mu'in al-din Chisti; his shrine in Ajmer remains one of India's most important pilgrimage centres to this day. The Shaykh's grandson Baba Farid Ganj-iShakar of Pakpattan and his grandson Nizam-al-din Aulia of Delhi proved to be just as influential as their illustrious ancestor: the shrines of all three continue to attract a huge number of devotees, including a significant number of Hindus in amongst the Muslim majority.

Yet just what was it about the Chishtiyya approach that proved so attractive to Punjabi converts? That the three great Shaykhs were men of immense spiritual charisma is beyond doubt, but that, in itself, does not provide a sufficient answer. Perhaps the most significant feature of the Chishtiyya approach was their routine use of vernacular forms of expression to make allegorical interpretations of everyday experience - of farming and cattle herding, of weaving and spinning and of the trials and tribulations of family life - around which to weave their spiritual and gnostic vision. ${ }^{15}$ It is also worth noting that their approach to spiritual inspiration would have been far from unfamiliar to those whom they were preaching. The Chishtiyya approach to proselytization was entirely congruent with the local Sahajiya tradition's emphasis on the profound spiritual insights which could be gained from a gnostic appreciation of the significance of participation in the natural world, and hence in the pleasures and pain of everyday being. ${ }^{16}$

Yet just how Islamic were Chishtiyya teachings? To set the whole process in context, it is worth remembering that this mission to South Asia took off shortly after the death of Ibn 'Arabi (1165-1240 CE), whose richly illuminating theological and gnostic explorations have been a key source of inspiration to mystically minded Muslims ever since. Not only was Mu'in ad-din a contemporary of Ibn 'Arabi, but it is very reasonable to suppose that he encountered the Master directly during the course of the visit he made to Damascus immediately prior to settling in South Asia. What is beyond question, however, is that right from the outset Ibn 'Arabi's immensely influential cosmological doctrine of wabdat al-wujud provided a key element of Chishtiyya teaching. Lapidus sums up the complexities of this doctrinal vision with accuracy and economy:

Everything which exists is God. The divine reality transcends all manifestations, but the manifestations are encompassed by and plunged in God. While God is transcendent the manifested world is identical with him in essence. A hadith says: 'I was a hidden treasure and I longed to be known so I created the world that I might be known'. All manifestations which reveal God are but the veils which conceal him. The reality of the universe is manifested on several planes; the lower planes being symbols of the higher. The highest is the absolute essence 
of God; there follow in the hierarchy of being the attributes and names of God, the actions and the presence of lordship, the world of spiritual existences, archetypes and forms, and finally, the world of senses and sensible experience. ${ }^{17}$

This theosophical vision of the structure of the cosmos has immediate consequences for the pursuit of gnostic experience, for as Lapidus goes on to indicate, it also follows that:

By contemplating the cosmos, we become one with the universe. Thus human beings occupy a privileged place in creation, for they are capable of rising above their place in the material world to return to their true home in the presence of God ... the sensible world is but a dream, and must be interpreted to reveal the divine reality to which it points. Everything in nature is a symbol of haqq, the divine reality.

This return to God is motivated by love; it is driven by prayer and worship.... God is the mirror in which man contemplates his own reality, and man is the mirror in which God knows his essence. Man needs God to exist, and God needs the world to know him. ${ }^{18}$

When confronted with complexity and sophistication of Ibn 'Arabi's theological vision, it is easy for those whose experience of philosophical debate has been confined to the arena of post-enlightenment secular rationalism to conclude that ideas of such complexity would fly straight over the heads of unlettered peasants. Such a conclusion could not be more erroneous. Not only was the indigenous population of the Punjab already familiar with the broad outlines of Sahajiya thought, but they would consequently have been familiar with the equally complex theology of viraba bhakti, ${ }^{19}$ in both its saguna and nirguna formats, ${ }^{20}$ which was popularly espoused through the Gita Govinda ${ }^{21}$ and the Bhagavad Purana. ${ }^{22}$

To those who expect religious traditions to remain neatly confined to separate boxes, poetic discourses which simultaneously articulate accounts of the ecstatic experience of 'ishq derived from Ibn 'Arabi's doctrine of wabdat al-wujud, Tantric Buddhist accounts of the way in which the path of sabaj can be used as a means of experiencing the entire gamut of cosmic processes within oneself, and which then top everything off with celebrations of the bitter-sweet experiences of viraba (a key feature of the Hindu devotional tradition) might seem to give rise to an impossibly tangled jumble of mixed metaphors. Yet despite the superficial diversity of these apparently disjointed perspectives, there are three critical points at which in which all three share a congruent set of assumptions. First that the macrocosm, the cosmos itself is structured on exactly the same basis as are all its microcosmic parts, most especially ourselves as human beings; secondly, and consequently, that what is true of the macrocosm is also true of the microcosm; and thirdly that the unqualified Source from which all existence sprang is replicated on a microcosmic scale in every nook and cranny of created existence, and most especially at the heart of human beings.

The presence of such congruence has had many consequences: in the first place it made for an easy exchange of ideas and understandings, and hence of mutual inspiration as between traditions which less-knowledgeable observers have frequently assumed were wholly discrepant; secondly, it actively facilitated the use of spiritual charisma as 


\section{Popular Islam in northern Pakistan and its reconstruction in urban Britain}

a means of proselytization, as the huge impact of the Chishtiyya Shaykhs and their teachings on the indigenous population of Hindustan very clearly demonstrates; thirdly and more generally, it provided fertile ground for the emergence of a highly distinctive Indo-Islamic cultural synthesis, no less in terms of art and architecture, poetry, music, dance and religion, which reached a peak of magnificence during the Mughal period.

\section{The historical roots of popular Punjabi culture}

By now some readers may be feeling bemused: having begun by indicating that the central objective of this chapter was to explore the logic of popular religious practice in rural Punjab, an exploration of its historical roots has taken us in quite the opposite direction. Not only has it required us to take note of what many may regard as arcane dimensions of Muslim, Buddhist and Hindu cosmology, but has eventually led us to take note of the high levels of artistic and intellectual creativity achieved during the Mughal period: the 'high culture' of a 'great tradition' if ever there was one.

It goes without saying that the Indo-Islamic cultural conventions which emerged in rural Punjab were far from being wholly congruent with those which by members of the Mughal Empire's aristocratic elite so carefully cultivated amongst themselves. Nevertheless I would argue that the common assumption that local traditions such as those found in rural Punjab were nothing but pale (and hence inferior) copies of superior ways of the urban elite is as patronizing as it is misleading, especially in the light of philosophical outlook which both the Sufis and the Sahajiyas went out of their way to articulate. Not only did India's most respected Sufis actively reject the pleasures and temptations of royal courts in favour of the opportunities for peaceful contemplation in the jungle, but as Das Gupta also indicates:

The poets of the Sahajiya school laid the whole emphasis on their protest against the formalities of life and religion .... [They] were averse to the elaborate formalities of religion and concentrated their attention on the attainment of blissful ultimate nature as the highest truth, for which they took help of the natural propensities of man .... Deepest was their hatred towards those recondite scholars who would try to know the truth through discursive reason... . The truth which can fully be realized only by the self can never be known by the scholars, for what comes within the scope of our mind can never be the absolute truth. ${ }^{23}$

Having thus rejected the sophisticated formalism of both the aristocratic and the scholarly elite, those pursuing this strand of practice sought inspiration - as did Guru $\mathrm{Nanak}^{24}$ - in the ever-deeper appreciation of the everyday world. Hence for them it was through the gnostic experience of the rhythms of nature rather than of abstract philosophy, of sexual activity rather than sexual abstinence, and above all of everyday domestic and agricultural activities rather than through participation in the ritual of royal courts that the route to sahaj could best be opened up.

The profound difference between these two approaches can immediately be appreciated if one compares Manjhan's aristocratically oriented tale of the mutual devotion of Manohar and Madhumalati ${ }^{25}$ with Waris Shah's much more rurally oriented tale of the 
life and love of Hir and Ranjha. ${ }^{26}$ Both poems are similarly structured: there is a strong sense in which both radically extended versions of Jayadeva's Gita Govinda. As such they present elaborately allegorical (and hence gnostically inspirational) accounts of two lovers' experience of ecstatic union and equally painful separation, thereby establishing a multi-dimensional space within which to conduct an exploration of the trials and tribulations - as well as the brief ecstatic pleasures encountered by those who throw themselves body and soul into the experience 'ishq, rasa, viraha, sabaj, fana, baqa and so forth. In doing so the symbolic logic of each story undermines all conventional distinctions between the Hindu and the Islamic traditions: in a graphic illustration of creative power of Indo-Islamic religious and cultural syntheses, both tales make equal sense from either perspective. Nevertheless there are huge differences in the way in which the two approach their goal. The first is written in courtly Hindawi, the second in common Punjabi; the first tells of aristocratic princes and princesses, whilst in the second the protagonists' lifestyles are comprehensively congruent with those of everyday Punjabi villagers; and whilst the first flaunts its 'cleverness' by incorporating all manner of oblique literary, scholarly and philosophical references, the second carefully avoids such overt scholarly pretentiousness. Indeed, apart from few explicit statements which appear in the opening and closing sections of his text, Waris Shah's rendition of the tale of Hir Ranjha makes few direct efforts to underline the multiple allegorical images which run right through it. This apparent parsimony is wholly in keeping with the Sahajiya view that if the Ultimate is embedded in everyday existence, it follows that any kind of intellectual artifice is more of an obstacle than a signpost towards an appreciation of the Truth. Hence if those without eyes to see or ears to hear describe the story as 'a Punjabi Romeo and Juliet' - as they not infrequently do - then so be it. If the experience of hearing it is sufficiently entertaining, perhaps the channels of understanding will open a little wider next time round, and yet more still after each successive hearing.

Not only does folk wisdom in rural Punjab strongly support this latter view, but a careful reading the poem's invocation and epilogue provides clear directions as to how its secrets can be unlocked - although characteristically enough in the context of a Sahajiya-inspired text, the instructions have to be read from back to front. As the epilogue puts it:

The story of true lovers is like the scent of a rose in a garden. He who reads it with love in his heart will be able to separate the true from the false. I have written a poem of much pith even as a string of royal pearls. I have written it at length and embellished it with various beautiful things. I have written it as a parable. It is as beautiful as a necklace of rubies ...

Oh wise man, you should note that there is a secret under the guise of my words. I have written this Hir with care and meditation. Young people read it with pleasure. I have planted a flower to give a sweet savour ...

Meanwhile in the invocation we find Waris explaining:

In truth it is meet and proper to praise God and invoke the help of Saints and Prophets before essaying this story of Love. My friends came to me and said, 


\section{Popular Islam in northern Pakistan and its reconstruction in urban Britain}

'Write for us afresh the forgotten story of the Love of Hir'. So we have written it right cunningly and plucked a new rose in the Garden of Poetry. Even as a sweet smell cometh out of musk so is the fragrance of love distilled from the beauty of our verse. We have bridled the steed of genius, set Love on his back, and let him loose on the field.

But just what is the Love of which the poem sings? The opening words of the poem make that quite clear:

Praise be to God who made love the foundation of the world; God Himself was the first lover for He loved the Prophet Muhammad.

In other words the subject of the poem is 'ishq — the route which devotees must take if they are to follow the Prophet's Sunna as the beloved of Allah.

This kind of approach to spiritual and gnostic exegesis remains very familiar to contemporary Punjabis, not so much as a result of a familiarity of the entire corpus of Waris' text, but rather as a result of frequent references to episodes and epigrams to the tale in everyday speech. In recent years this powerful undercurrent of popular culture has been powerfully reinforced by the immense popularity of the qawwalis ${ }^{27}$ of the late Nusrat Fateh 'Ali Khan. Drawn from a long lineage of devotional qawwali singers, his lyrics are grounded as much in the poetry of Bulleh Shah as they in the imagery of Hir Ranjha; and in multifariously celebrating the bitter-sweet experience of 'ishq his qawwalis not only inspire those audiences fortunate enough to be able to attend a live performance, but thanks to the widespread reproduction of his songs on $\mathrm{CD}$, his inspirational interpretations now eagerly circulate around a global Punjabi community. In consequence Nusrat Fateh 'Ali's celebration of the spiritual and gnostic insights which underpin the Punjabi religious tradition find almost as ready an audience amongst Hindus and Sikhs as they do amongst Muslims.

It goes without saying that neo-conservative purists invariably view the ongoing popularity of qawwali with alarm: in the light of their understanding of the Prophet's Sunna, such interpretations of Islam are wholly misguided. However, my reason for highlighting their criticism here is to not open a judgemental debate about the rightness or wrongness of any given interpretation of the Prophet's message. Rather it is to make an empirical observation: that the popular culture of the Punjab, and most especially the spiritually oriented dimensions remain to this day one of the central vehicles through which popular religious understandings are experienced, transmitted and expressed - no less in the diaspora than in the Punjab itself. But just as in every other corner of Dar al-Islam, these processes are far from uniform. Each has taken place in a specific local context, whose historical specificities remain an intrinsic component of the final product. Hence Hir, no less than in Madhumalati, is a richly elaborated hybrid. Popular religion, no less than popular culture, is the product of creative interweaving of a range of traditions whose many components comprehensively interpenetrate - and hence mutually illuminate - one another. Are the resulting interpretations 'un-Islamic'? That is not a question for me to resolve. All I would note is that if the answer is 'yes', it follows that the same judgement must also 
be made of the teachings of Sufi luminaries such Ibn 'Arabi and the Chishtiyya pirs, ${ }^{28}$ whose philosophical, theological and cosmological insights underpin Nusrat Fateh Ali's contemporary qawwalis just as comprehensively as they do Waris Shah's Hir.

\section{The reconstruction of popular Punjabi Islam in Britain}

So far I have deliberately restricted my discussion of the historical roots and contemporary manifestations of Islamic practice in the Punjab to developments in its indigenous home base. However, during the course of the past half century an ever-growing number of Punjabi Muslims have set off overseas as labour migrants, and have by now established thriving ethnic colonies in the Middle East, the United States, in Germany and Denmark, and last but not least in the UK: Britain's Pakistani Muslim population is now rather more than three quarters of a million strong. The more firmly such migrants - as well as their overseas-born offspring - have established themselves in their new homes, the more comprehensively they have begun to reconstitute almost every aspects of their social, cultural and religious heritage. The results are now plain to see: a multitude of self-sustaining ethnic colonies have by now sprung to life within the heart of most British cities.

With such considerations in mind the remainder of this chapter focuses on three main themes: firstly, on the ways in which settlers have set about re-establishing the most significant features of their own familiar religious universe in urban and largely post-Christian contexts; secondly, on the changes and transformations precipitated during the course of these processes of reconstruction; and thirdly, on the increasingly vocal challenges to their parents' heritage which their British-born offspring are now beginning to articulate. In parallel to developments elsewhere in the Islamic world, many of Britain's upwardly mobile and educationally successful young Muslims find themselves strongly attracted to scripturally inspired neo-revivalist movements such as the Jama'at-i Islami, the Tabligh-i-Jama'at and Hizb ut-Tahrir. Besides providing them with a ready means of challenging the anti-Islamism which has become such a salient feature of contemporary British society, such movements also provide them with a ready means of distancing themselves from their parents' beliefs and practices on the grounds that they are irrational, illegitimate and most critically of all, that they are 'Hindu' rather than 'Islamic' in character.

\section{The early pioneers}

It goes without saying the dynamics of these developments which have precipitated these outcomes need to be set within their specific socio-historical context. The Punjabi Muslim presence in Britain can be traced back to arrival of ex-seamen and ex-soldiers during the course of the Second World War, many of whom were promptly recruited to provide additional manpower for labour-starved munitions factories. Those pioneers who stayed on into the post-war period provided a bridgehead for further settlement. Hence when Britain's labour-intensive foundries and textile mills ran acutely short of unskilled labour with the onset of the post-war boom, each of these bridgeheads became the focus of ever-escalating inflows of chain migration, most of which 


\section{Popular Islam in northern Pakistan and its reconstruction in urban Britain}

were directed towards industrial cities in the Midlands and the Pennine region. Conditions were hard. Restricted to jobs which no-one else wanted because they were hot, hard, unpleasant and anti-social in character, Pakistani Muslims found themselves standing right at the bottom of the British social order. Not that they cared very much. Although constantly on the look out for jobs which offered marginally better pay and conditions, few of the early pioneers regarded themselves as anything other than temporary sojourners in a wholly alien environment. Hence they were prepared to work all the hours God gave for six or even seven days a week, to pare down their living expenses to the lowest possible level, and to defer almost all forms of personal gratification to speed the day when they could leave the hell-hole of urban Britain behind them. Their goal was clear: the greater the extent of their personal sacrifice, the more swiftly they could take their new wealth back to the ease and comfort of their real homes. ${ }^{29}$

In such circumstances, sojourners made little effort to maintain the niceties of civilized life. Any effort that they might make to do so seemed as pointless as it was unrealistic. Not only were the necessary physical resources largely unavailable, but the very pursuit of such goals contradicted the central purpose of their whole enterprise: to earn and save as much money as possible as quickly as possible. Given all this, conformity to the formal behavioural principles of Islam largely went by the board. Collective prayer was virtually non-existent, and even the personal performance of namaz was rare. To be sure, the consumption of pork was usually avoided, but little else. Pubs offered the only site for a little relaxation, whilst prostitutes were occasionally hired to satisfy what these hard-working men regarded as their necessary physical needs. Otherwise they lived a life of endless labour. In the midst of all this many sojourners may well have turned to poetry and music - or in other words to the resources of the popular traditions outlined earlier - no less as a source of psychological succour than of spiritual inspiration. Whilst I can offer little concrete evidence that this was so in the case amongst the earliest of Punjabi Muslim sojourners, Joginder Shamsher provides extensive evidence of the richness of these developments amongst their Sikh counterparts. ${ }^{30}$

\section{Desh Pardesh: the reconstruction of a social, cultural and religious universe}

This pioneering phase of comprehensive social and cultural abnegation could not, however, be sustained for ever. Contrary to their initial expectations, most sojourners found the passage to Britain was an entrepreneurial exercise with long-term consequences. Hence whilst almost everyone eventually took their longed-for furlough in Pakistan, during the course of which their savings provided them with an opportunity to savour all the pleasures for which they had sacrificed so much, their trip to paradise could not last for ever. As the returnees' savings were steadily depleted, few could resist the temptation to yet further boost their assets by return to the treadmill for a further spell of wealth-generation.

Nor were they alone in doing so. Since the material benefits of migration were as massive as they were self-evident, every returnee found himself besieged by friends and kinsfolk seeking advice and assistance as to how best to follow in their footsteps. 
Hence from the 1960s onwards the scale of the South Asian presence in Britain began to follow a pattern of almost exponential growth. With this the toeholds which the sojourners had initially carved out for themselves were gradually opened up into ever more substantial niches, which in turn began to develop into more fully fledged ethnic colonies. Once that transformation had occurred, those involved began to make ever more intensive efforts to reconstruct all the major social, cultural and religious institutions of their homelands. ${ }^{31}$

Whilst this switch from temporary sojourner to more firmly rooted settler is commonplace enough, the Pakistani Muslims who made their way to Britain - and most especially the Mirpuris from Azad Kashmir who made up well over half their number moved much more tardily towards reuniting their families (the ultimate sign of colony-construction) than did any other group of South Asian origin other than the Bangladeshis. ${ }^{32}$ As a result Britain's Mirpuri population was still overwhelmingly composed of adult males until well into the 1970s. Nevertheless, by then processes of more active religious reconstruction had gradually begun to take off. Groups of men who had taken up residence in a single locality, and especially those linked by ties of common kinship began to pool their resources to buy small terraced houses which could be used as mosques, and to recruit Maulwis to lead them in their prayers. When the congregations began to overwhelm such premises they went on to buy larger houses, disused churches and even mills and office blocks to serve the same purpose. Islamic Britain was beginning to crystallize. ${ }^{33}$

\section{Mosques and their organization}

Mosques in Britain soon began to fulfil a wider set of functions than do their counterparts in rural Punjab. Especially in the early days, the mosque was the only arena in which sojourners-turning-settlers could gather collectively on their own terms. Hence besides providing an arena for the collective performance of namaz, they also became gathering points in which lonely men could meet, socialize and exchange information a function which they retain to this day. Moreover, when settlers were joined by their wives and children from the mid-1970s onwards, mosques gained a more explicit educational function. The Maulwis' duties were expanded to include teaching children to read, recite and memorize the Qur'an in classes which were normally held every afternoon after the close of school. Mosques became increasingly busy places.

In the early 1980s the settlers' commitment to religious activities received a boost from an unexpected source: a major industrial recession to which many Pakistani Muslim communities found themselves disproportionately vulnerable. Although textile mills and iron foundries had long provided them with a stable, if relatively ill-paid, source of employment, the sector of the labour market on which they had come to rely suddenly collapsed. The consequences for middle-aged Pakistani men living and working in the Pennine region were devastating. Most had very limited fluency in English, few transferable skills and were also in the midst of reuniting their families. Suddenly reliant on unemployment benefits which were usually rendered relatively generous as a result of the size of their families, they also found themselves with unlimited time on their hands. What were they now to do with themselves? 


\section{Popular Islam in northern Pakistan and its reconstruction in urban Britain}

Whilst many younger men took to taxi-driving or opened take-aways, ${ }^{34}$ the elders found themselves faced with a narrower range of options. Some opened shops, or assisted their kinsmen in the businesses in which they were already engaged; others took allotments, and began to grow vegetables; however, large numbers of men more 'elderly' men (many of whom were no older than their early forties) gravitated to the mosque, where a new-found enthusiasm for prayer provided then with a means of restoring at least some degree of meaning and purpose to their lives. Congregations began to grow by leaps and bounds, existing mosques began to be refurbished and repainted, and ever more efforts began to make to raise the funds for the construction of purpose-built mosques whose domes have now begun to pepper the skyline of many British industrial cities. ${ }^{35}$ Moreover, these new mosques are hives of activity. In addition to hosting regular daily prayers - and huge congregations at midday prayers on Fridays - most also support an after-school madrasa, and have very often successfully gained access to substantial local authority and urban regeneration funding to support 'community centres' of one kind or another. ${ }^{36}$ All this has served to support the rapid reconstruction of the behaviourally oriented dimensions of religious practice within each of Britain's multiplicity of Pakistani Muslim ethnic colonies.

Nevertheless the passage to Britain has begun to precipitate significant transformations in everyday practice. Given the need to register themselves as charities, as well as to conform to local safety and planning regulations, each mosque had to give itself an acceptable organizational structure, such that power and financial responsibility was assigned to a formally constituted management committee. Whilst this posed no great problem in principle, since such committees simply replicated the more informal structures utilized back home in the Punjab, their greater degree of administrative formality concentrated a great deal of power in the hands of the Chairman of the Management Committee. Hence ferocious factional struggles frequently erupted for control of this office, especially when it also provided effective control over the spending of substantial amounts of Local Authority regeneration funding. It is also worth noting that in keeping with Pakistani traditions, the Chairman and his fellow committee members kept the closest of tabs on the Maulvis whom they chose to employ. Whilst Maulvis may have been treated with respect, power remained firmly in the hands of the laity, just as it does in rural Punjab, where Mullahs and Maulwis are firmly regarded as kammi, village servants. Hence the Bradford Council of Mosques, a body which was explicitly formed as a means of articulating the local Muslim community's collective interests, has always been composed of members of its constituent mosques' management committees. ${ }^{37}$

\section{Pirs and their re-emergence}

In contrast to formally constituted mosques, the more spiritual and occult dimensions of popular belief and practice have much less formal organizational roots. Hence whilst the organization and construction of mosques still provides the most overt manifestation of an Islamic presence in Britain, just as images of congregational prayers within them provide a clear indication of the re-emergence of behavioural orthodoxy, it would be quite wrong to conclude that the paucity of overt indications of the re-establishment 
of the more spiritual and occult forms of popular practice means that this dimension of Punjabi Islam has fallen into abeyance in the UK. Far from it: from its early roots as source of inspiration to the early sojourners, activities in this sphere were powerfully reinforced as family reunion began to take off from the mid-1970s onwards. That it should have done so should be a cause of no surprise: just as they did back in the Punjab, settlers who found themselves facing intractable personal difficulties turned to this dimension of their tradition for succour and support.

But whilst recourse to the more spiritual and occult dimensions of popular practice has become increasingly frequent in every ethnic colony in the UK, it has also become a focus of considerable contention, not least because women tend to be much more avid consumers of the pirs' services than men. Could it be that this is the result (as many male critics suggest) of women's inherent tendency to be 'more emotional', 'less well informed' and 'more superstitious' than men? In my view such arguments should be regarded as wholly specious, since a much more illuminating perspective on the rationale behind women's use of such resources can be gained in the light of a consideration of the nature and extent of their responsibilities within the domestic group. However much formal authority men may claim over the affairs of their extended families, it is quite clear that whenever serious trouble erupts in the domestic sphere - be it the illness of a child, troubled marital relationships, a daughter-inlaw's failure to produce offspring or of a teenager going off the rails - it is the women of the household who are expected (and who indeed expect) to sort these matters out. Hence family reunion in Britain presented settlers' wives with two parallel sets of challenges: on the one hand, to find some means of resolving these only too familiar forms of personal and interpersonal difficulties in a largely alien context, and on the other, to find some means of coping with all the novel challenges precipitated by residence in urban Britain. How and when should one wean a child when fresh vegetables and milk from the farm are unavailable? What remedies should one use for everyday aches and pains in the new circumstances? How should children be fed and dressed in an environment which is much colder, much wetter, and so much more bleakly urban than anything than they had hitherto experienced? How should daughters be prepared for the perils of sexuality in the midst of society which appeared to lack any sense of shame or personal modesty? The list could be extended indefinitely through the whole life cycle. Nor were these issues themselves the only challenges. A much more profound set of queries came to the fore when things went wrong: when illness, accidents and other kinds of disasters struck.

To be sure, settlers could now make use of all sorts of public services - most especially in the field of health care - which were largely unavailable back home. But however welcome access to such facilities that might be in principle, it turned to be far from easy to make full use of them. Communication proved to be a huge problem: few doctors or nurses spoke Urdu or Punjabi, and most assumed that it was their patients' responsibility to learn English if they wanted to gain access to treatment. Moreover, even if settlers managed to overcome such barriers to communication - which relatively few of the first generation of women did with any speed, given that they were tied down by so many more pressing domestic responsibilities - they immediately encountered an even more serious hurdle. Given that staff responsible for the delivery of 


\section{Popular Islam in northern Pakistan and its reconstruction in urban Britain}

public services - whether in medical, psychological, social or educational contexts - for the most part lacked the requisite degree of cultural competence, they all too often misdiagnosed the precise character of the difficulties faced by their minority clients. Hence whilst public services displayed a welcome capacity to respond to financial adversity with benefit payments, and to remedy the more physical aspects of personal distress (such as setting broken bones, diagnosing strokes and heart attacks, and identifying childhood abnormalities as being of genetic origin), they were much less well equipped to respond to the more qualitative and metaphysical dimensions of their Pakistani clients' concerns. Answers to such pressing questions as to just why misfortune should have struck just then, there, and have been directed that particular victim went unanswered, as did their equally pressing concerns about the precise steps that should be taken to ensure that the malevolent forces which had precipitated the difficulties in question would not strike again.

All this stood in marked contrast to settlers' experience back home in rural Pakistan. Precisely because services with which to remedy the physical dimensions of personal problems are so limited - and so expensive - in that context, villagers routinely turn to pirs and their shrines in an effort to resolve the worst of the spiritual and psychological difficulties they encounter in the course of their everyday life. Hence it should come as no surprise that they have continued to look to such sources of succour in the aftermath of their passage to Britain, and that as the years have passed, increasingly sophisticated responses to those needs have begun to emerge.

At the outset those responses were wholly ad hoc. Insightful individuals, and especially those who had some experience of such activities back in the Punjab, began to do their best to assist their fellow migrants, and if their interventions proved successful it was not long before they began to attract an ever-increasing number of clients. But if local practitioners were unable to provide a remedy and the affliction became steadily more serious, those in distress often concluded that the most appropriate course was to make a pilgrimage back to Pakistan to seek the assistance from betterestablished pirs and shrines. Yet although such pilgrimages continue to be made, the need to do so is steadily diminishing: as ethnic colonies in Britain expanded rapidly expanded in both scale and sophistication, not only have more or less full-time pirs begun to emerge in the UK, but following their deaths (of which there have been relatively few so far) their devotees have begun to transform their tombs into ever more fully-fledged shrines. Slowly but surely, the whole panoply of popular practice in rural Punjab is steadily being recreated in Britain. To my knowledge, no detailed ethnographic study of these developments in the UK has yet been conducted. What I can confirm, however, is that when families of rural origin run into serious difficulties in Britain - and in the course of my professional practice as a consultant anthropologist I very frequently come into contact with families in this position - I invariably find that they have visited a succession of pirs and shrines (certainly in Britain, and very often in Pakistan as well) in an effort to resolve their problems.

Similar processes of imaginative reconstruction have also taken place at all sorts of other levels. Hence, for example, most villagers would have had few opportunities to absorb the significance of lyrics of qawwalis, unless they made regular pilgrimages to the "urs of major shrines, where such performances are a central item on the spiritual 
agenda. In Britain, however, tape-recorders and then CD players were widely available. And it was not just film songs from Bollywood to which settlers listened: recordings of numerous performances by maestros such as Nusrat Fateh 'Ali Khan are sold in huge numbers in the UK, whilst large and ecstatic audiences attended all his live performances. In other words the first generation of Punjabi settlers in Britain - most of whom still have many years of active life before them - have by now actively reconstructed most aspects of the religious world within the context of which they grew up around themselves. However, it would be a great mistake to conclude that this process is the outcome of simple unthinking traditionalism: it is precisely because of the depth and complexity of the challenges with which settlers have found themselves confronted that they have turned with such enthusiasm to the sources of psychological and spiritual succour which the popular religious traditions of the Punjab so readily supply.

\section{The British born and raised second generation}

Once we move on to consider the response of the British-born second generation to these challenges the picture becomes a great deal more complex. Most Anglo-Asian Muslims are fiercely proud of their religious heritage, not least as a result of their constant exposure to racial and ethnic exclusionism. But although they are consequently strongly committed to presenting themselves as Muslims, many have by now become deeply critical of their parents' interpretations of the Islamic tradition, with the result that they have begun to add all sorts of additional dimensions to the process of religious reconstruction in the UK. However, the dynamics of these processes have now become exceedingly complex: not only are the younger people beginning to follow an ever more diverse range of adaptive trajectories, but whatever the course they choose, most are just as eager to distance themselves from the attitudes and conventions of their parents as they are from those preferred by the English majority.

In making sense of these responses, two points are crucial. In the first place it is essential to remember that just because someone is comprehensively familiar with English linguistic and behavioural conventions, it certainly does not follow that the person in question is necessarily 'English' in any existential sense. Most young Anglo-Asians have now become sophisticated cross-cultural navigators, such that they can manoeuvre their way with just as much ease through arenas structured in terms of their parents' cultural conventions as they do in those where they are expected to conform with those deployed by members of the dominant majority. ${ }^{38}$ Yet despite their development of extensive navigational skills, which also include those which they deploy in their own self-constructed Anglo-Asian arenas, it is now becoming increasingly clear that relatively few of those who were both born and brought up in Britain still use Punjabi or Urdu as their principle vehicle for communication. English has become their first language, most especially amongst the ever-increasing proportion of young people who are achieving educational and professional success. As a result an ever-increasing proportion of Anglo-Asians have no adequate means of comprehending, and hence lack access to, the conceptual universe 


\section{Popular Islam in northern Pakistan and its reconstruction in urban Britain}

within which their parents operate. Hence while most are familiar with behavioural dimensions of the popular practices outlined in this chapter, the conceptual logic around which those practices are constructed are quite literally beyond their ken.

The outcome of these developments is now plain to see. In intellectual terms there is a strong sense in which the rising generation of Pakistanis are comprehensively anglicized. Not only has the greater part of their educational development taken place within an English linguistic universe, with all its attendant cultural and conceptual assumptions, but they have rarely if ever been provided with an opportunity to explore the distinctive aspects of their religious and cultural heritage in its own terms. The consequent dilemmas are huge: despite their intense commitment to Islam as a means of flagging their own personal self-identification, many aspects of their parents' interpretation of that tradition - and most those of its dimensions which appear to be as irrational as they are superstitious - leave them with feeling of deep intellectual and conceptual unease.

But despite their ever-growing concern to distance themselves from those aspects of their parent's heritage which they consequently identify as 'backward', 'primitive' and 'obscurantist', only a small minority find the prospect of identifying themselves as 'English' either meaningful or attractive: the strength of majority devaluations of Pakistanis in general and of Muslims in particular rules out any such possibility. In these circumstances the issue of identity has become increasingly problematic for young Anglo-Asians. If the preferred lifestyles of their parents leave them feeling almost as uneasy as those deployed by the native English, just how should they identify themselves? And around what sorts of ideas and values should they seek to organize their personal lives?

For many, 'pure' Islam now provides an attractive answer all such questions, not least because it provides them with a means of simultaneously confronting both horns of their underlying dilemma. Turning to Islam very publicly is undoubtedly an extremely attractive option in the face of ever-rising levels of ethno-religious exclusionism. Not only does Islam explicitly identify itself as the culmination of the Abrahamic tradition, but its long historical role as Christianity's bête noir makes it a wonderful instrument with which to challenge white, European and post-Christian denigration. However, this does not in itself provide a solution to the second horn of their dilemma: their feelings of shame about what they have to come to view as the inherent 'backwardness' of many aspects of their parents' lifestyles, let alone the manifestly 'superstitious' character of so many of their religious beliefs and practices. Hence it is precisely because they actively reject all these dimensions of popular practice that neo-revivalist movements such as the Tabligh-i-Jama'at, the Jama'at-i Islami and the Hizb ut-Tahrir have found such a ready audience amongst the younger generation: they provide an extremely effective and intellectually coherent means of addressing both arms of their dilemma.

The precise reasons why this is so are worth reviewing. On the domestic front, neorevivalism provides young people with a highly effective means of taking the moral high ground vis-à-vis established dimensions of popular practice. Above all it legitimates the rejection of all those aspects of their parents' priorities which they find unacceptable - including making pilgrimages to shrines, the use of $t a^{\prime} w i z$, the view 
that higher education is unsuitable for girls, and above all to the expectation that parent have a duty to arrange their children's marriages - as erroneous, un-Islamic and worse still, 'Hindu'. Meanwhile it also provides an equally effective foundation around which to construct defensive arguments against external critics. In the face of negative comments about the inherent 'backwardness' of custom and practice in local Muslim communities, they now have a ready answer to hand: that everything so criticized is not really Islamic at all, but an unfortunate accretion which has led some Muslims into making some misguided deviations from the straight path.

However, the adoption of neo-orthodox perspectives provides much more than a means of keeping such negative forces at bay: it also fosters positively inspirational, and indeed millenarian, outlook of a kind which student idealists have always found attractive. To be sure, Islam may be under attack, whether in Bosnia, Kosovo, Chechnya, Kashmir, Palestine and indeed, the streets of Bradford. However, this only draws the response that Islam is now the world's fastest growing religion, and that despite the intensity of the forces bearing down on Muslims everywhere, Khilafat will come! Against this background, groups such as the Hizb ut-Tahrir conceive of themselves as forming an elite vanguard, whose structure and appeal is closely congruent with those which underpin many Trotskyite groups on the far left. Adopting dedicated and austere lifestyles grounded in a sense of ideological purity, they see themselves as the emergent leadership of a future Islamic (as opposed to socialist) uprising.

Whether or not one sympathizes with such a goal, or indeed whether or not its achievement is in any way realistic, the adoption of such an outlook brings clear benefits, at least in the short term. Partying, the most favoured leisure activity amongst young people drawn from the ethnic majority, is left firmly to one side. Instead austerity, uprightness, dedication and above all hard work - the central characteristics of the protestant ethic - are very much the order of the day amongst the faithful. Neo-revivalism is far from being incompatible with academic and commercial success. On the contrary, the two tend to be self-reinforcing: given the scale of the exclusionary obstacles which people of colour so regularly encounter, and the extent to which they must of necessity look to their own resources if they are ever to overcome them, neo-revivalist behavioural strategies tend to precipitate positive material benefits.

Nevertheless it is now becoming increasingly clear that these developments also have a serious downside, not just amongst the students who are the most enthusiastic proponents of such perspectives, but also within Britain's Muslim communities at large. Like so many other politically driven ideologies, and most especially those which are defensively conceived, neo-revivalism is a highly effective recruiting sergeant; but by just the same token it one which finds it difficult to retain such recruits over the longer term. It is easy to see why. Despite its capacity to provide ideologically grounded solutions to the dilemmas with which young Anglo-Asians so frequently find themselves confronted, the lifestyles which it predicates are austere in the extreme. According to its protagonists almost all forms of pleasurable relaxation - from music and dance through to watching films and television - should be foresworn by pious Muslims. In the same vein, neo-revivalism is equally dismissive of any kind of reflective 


\section{Popular Islam in northern Pakistan and its reconstruction in urban Britain}

engagement with Islamic history, or indeed with the richness of the creative hybridity which underpins every dimension of the Indo-Islamic religious, linguistic and cultural synthesis.

To be sure, those who take their stand on prescriptive and essentialist interpretations of Islam provide themselves with an excellent means of keeping pestilential Western enquirers at bay behind a wall of absolutism. But whilst the adoption of fullscale hijab by many young women (for example) provides a very effective means of doing just that, it is well worth remembering that the there is no necessary correlation between the strictness with which a person maintains behavioural orthodoxy and the depth of their religious knowledge. Most devotees of neo-revivalism have far clearer notions of that which they reject than that which inspires them. Behavioural orthodoxy may indeed provide an excellent platform for political mobilization; but given that it offers so little in the way of intellectual and spiritual succour and its insistence that all forms of leisure and pleasure should be discarded, it should come as no surprise that that support for this vision rarely last much longer than its exponents' student years.

\section{Conclusion: Prospects for the future}

In Britain, as in Pakistan and indeed in almost every part of the Islamic world, support for neo-revivalism is currently growing apace, most particularly amongst the young and disadvantaged. But if current developments in Britain are anything to go by, the swing of the pendulum towards the behavioural end of the spectrum may well have reached its limits, and that as the more extreme forms of revivalism turn out to be unsustainable, at least in personal terms, in anything more than the short run the more spiritual and gnostic dimensions of the tradition as a whole may well begin to reassert themselves. And if that is indeed the case, future generations of Anglo-Asian will begin to make much more determined efforts by members of the younger generation to make much more creative use of all the resources of their religious, linguistic and cultural heritage, rather than the tiny section of that rich spectrum on which the neo-revivalists exclusively rely. If so, the neo-revivalists' current heroic efforts to reconstruct the lifestyles of seventh-century Hijaz could usefully be tempered by a much more positive appreciation of the totality of the resources bound up in their ancestral heritage.

\section{Notes}

1 It goes without saying that in Islamic terms Allah is a phenomenon which stands beyond all discrete qualities, and therefore has no gender. Unfortunately English, unlike Arabic, lacks non-gender specific pronouns.

2 This chapter is the product of a series of fieldwork visits to Indian and Pakistani Punjab, most of which were supported by grants from the ESRC, supplemented by further fieldwork within Mirpuri and Jullunduri ethnic colonies in the UK. Further visual material which graphically illustrates the arguments developed here can be found at http://www. art.man.ac.uk/CASAS/presentations/teaching/teaching.htm. 
3 This point is particularly clearly articulated in Harjot Oberoi's extended discussion of the cult of Sakhi Sarwar (1994: 147 ff.). Although written very firmly from the perspective of a British District officer, Aubrey O'Brien's account of 'The Mohammedan Saints of Western Punjab' (1911) contains a wealth of ethnographic detail and an excellent ethnographic account of these practices in early modern Punjab.

4 Shrines in the Punjab have a clear colour coding: green for Islam; blue and/or yellow for the Sikh tradition; orange for Hindus; and red for Ravidasis, Valmikis, and Ad Dharmis or in other words the shrines established by Dalits, the Punjab's former 'untouchables'.

5 A fuller account of these procedures, and of the logic which underpins them can be found in Roger Ballard (1999).

6 Numerous revivalist groups now articulate this view. The resultant policy of Islamization was explicitly encouraged by the Pakistani state, whilst General Zia ul Haq was in power, and has intermittently been supported by various regimes since then.

7 Michael Gilsenan (1990) addresses just the same issues as those confronted here in his still-unsurpassed analysis Recognising Islam: Religion and Society in the Modern Middle East.

8 As Mr Justice Munir emphasized in his still immensely illuminating report (Munir and Kayani 1954), this is much more difficult than is commonly appreciated. When it comes to matters of fine detail, 'ulama drawn from different schools of law invariably find much more about which to disagree than to agree.

9 B. D. Metcalf, (1982).

10 Usha Sanyal, (1996a).

11 Richard Eaton, (2000), Chapters 8, 9 and 10.

12 Tantric and Sahajiya developments in the Hindu and Buddhist traditions on north India are masterfully discussed by Shashibhushan Das Gupta (1969).

13 Eaton, ibid. 222

14 It is worth remembering that Hindustan has long been primarily a geographical rather than a religious identifier. It was used to refer all the territories to the West and South of the River Indus, together with their inhabitants.

15 Eaton (2000), Chapter 8, and Annemarie Schimmel, (2001).

16 Das Gupta, ibid.

17 Ira Lapidus, (1988, pp. 213-214).

18 Ibid., p. 215.

19 Friedhelm Hardy, (1983).

20 John Hawley, (1988).

21 Barbara Stoler Miller, (1977).

22 David Pockock, (1986).

23 Das Gupta (1969, pp. 51-53).

24 Khushwant Singh, (1991).

25 Aditya Behl and Simon Weightman, (2000).

26 Frederick Usborne, (1973).

27 Qawwali are the devotional songs in praise of both Allah and his Prophet, and then going to explore the complexities of 'ishq in the midst of wabdat-al-wujud which were traditional sung to celebrate the "urs of every buried pir.

28 In a masterly exposition, Desiderio Pinto (1995) shows just how comprehensively Ibn 'Arabi's theological and cosmological vision still underpins contemporary teaching and practice in Delhi's most important Chishtiyya shrine.

29 Abdullah Hussein provides a wryly graphic of the trials and tribulations of these early pioneers in his novel Émigré Journeys (2000).

30 Joginder Shamsher, (1989).

31 Detailed accounts of these processes can be found in Roger Ballard, (1994).

32 Roger Ballard, (1990).

33 Philip Lewis (1994) gives an excellent account of these developments in Bradford.

34 See Virinder Kalra, (2000). 
186 Popular Islam in northern Pakistan and its reconstruction in urban Britain

35 Thanks to planning objections, minarets are much more rarely to be seen than domes, and the domes which are actually constructed are usually very much smaller than the architect had originally proposed. It goes without saying that the towers and spires of Christian churches do not attract similar objections, but are regarded as a welcome addition to the urban skyline. Indeed planners usually make every effort to ensure that other buildings do not obscure them.

36 A detailed account of activities with such a local mosque can be found in McLoughlin (2004).

37 Philip Lewis, (1997).

38 R. Ballard, (1994, pp. 30-34). 


\section{Glossary}

Adab Proper behaviour, good manners

Adab islami works Islamicist literature

Ahl-i Hadith 'The followers of the Prophetic tradition'

Ahl al-Sunna Sunnites

Ahl-i Sunnat wa-jama'at The people of the tradition of the Prophet and the Community

Ahl al-tasawwuf Sufis, Islamic mystics

Ahl-i khidmat Serving dervishes

Ahwal Mystical states

'Aid-i fitr End of Ramadan

Al-insan al-kamil The perfect being

'Amal Practical worship

'Aqida Belief, faith

Ashram A Hindu hermitage, college

Awliya Holy men, 'friends of God'; pl. of wali

Baqa Persistence in the divinely bestowed attributes

Baraka The power to blessing

Barelwi Group called after its founder Ahmad Riza Khan from Barailly/India

Batin Inner meaning, internal

(giving) Bay'a Act by which the authority of the shaykh is recognized

Bid'a Innovation in religious practice or doctrine

Cemaat See jama'at

Dar al-Islam 'The land of Islam'/'house of Islam'

Dargah Dervish convent

Da'wa Call or invitation (to Islam)

Deobandi/Deoband school Group called after the seminary in Deoband/India

Dhikr 'Remembering' God, reciting the names of God

Du'a Optional prayer

Faiz Divine grace

Fana Being lost in God; fana fi Allah (annihilation in God, the complete merging with God)

Fata Socially free and unbound man

Fatwa Legal opinion, legal decision 
188 Glossary

Fiqh Islamic jurisprudence

Fuqaha Jurists, singl.: faqih

Futuwwat Generosity, virtue, moral behaviour, idealized attitude of men

Ghaiba Absence; among the Twelver Shi'ites the disappearance of the twelfth Imam; in mysticism also the condition of anyone withdrawn by God and whose life during that period may have been miraculously prolonged

Githa A sacred song or poem

Gyarvi sharif Ritual meal commemorating the birth/death of 'Abd al-Qadir al-Jilani

Hadith Tradition of the Prophet which features words attributed to God (hadith qudsi) and those of words of the Prophet (hadith nabawi)

Hajj Pilgrimage to Mecca

Halqas Gatherings/circles

Haqiqa/Haqq 'The truth', wisdom, reality

Haqiqa Muhammadiyya Muhammadan reality

Hizb ut-Tahrir The Party of Islamic Liberation, first among Palestinians in Jordan in the early 1950s. It advocates the overthrow of governments throughout the Muslim world and their replacement by an Islamic state in the form of a re-created Caliphate

'Ibadat Submissive obedience to the master, religious practice

Ikhlas Dedicating, devoting or consecrating oneself to something; utmost fervour

Ijazat Authorization; licence

Ijma‘ Consensus of the community

Ijtihad Individual reasoning

'Ilm Knowledge, religious knowledge

Istighfar Seeking God's forgiveness

Jama'at Meeting, assembly, community

Jama'at-i Islami The Islamic Community; political party established by A. A. Maududi (d. 1979) in 1941 with the aim to establish an Islamic government. Popular among middle class and youth, particularly in Pakistan

Jawanmardi Spiritual chivalry

Jihad Personal struggle, 'holy war'

Karamat Miracle

Khalifa Successor of the shaykh/vicegerent of God

Khanaqah A building usually reserved for Muslim mystics belonging to a dervish order; Sufi lodge, hostel for travellers; also ribat

Khatm al-anbiya Seal of prophethood

Khatm al-awliya Seal of the friends of God

Langar Sacralized food, freely offered

Madhhab School of law, pl. madhabib; e.g. Hanafite, Hanbalite, Shafi'ite, Malikite madhbab

Mahdi 'Who is the guided one'; the messiah

Mahabba Sincere/divine love

Malama Self-blame

Malfuzat 'Table-talks' of the saints; literary genre

Maneviat 'Spirituality' 
Maqamat Spiritual stations

Ma'rifa Mystical intuitive knowledge, gnosis

Maulid Celebration of the Prophet's or a saint's birthday

Maulwi Religious divine

Mazar Shrine, tomb

Mujaddid Renewer of the century

Mullah Religious scholar/counsellor

Murid Disciple, novice, follower

Murshid Teacher, master, spiritual guide

Nafs 'Lower' self, self, in contrast to ruh

Na't Poetry in praise of the Prophet

Nur Muhammadi 'Light of Muhammad'

Pir Sufi teacher, spiritual guide

Qawwali Sufic song

Ribat See Khanaqah; shrine/tomb

Ruh Virtuous spirit; as counterpart to nafs

Salaf Early righteous Muslims

Sama' Listening to music; mystical concert and dance

Shari'a Islamic law

Silsila Continuous chain of spiritual descent

Suhbat Company of the shaykh and other seekers

Sukr Intoxication

Tahajjud Optional night prayer

Ta'ifa Mystical groups

Taqlid Imitation of the Prophet; the unquestioning acceptance of the doctrines of established schools and authorities

Tariqa (Mystical) 'path', Sufi brotherhood, pl.: turuq

Tasawwuf Islamic mysticism

Tawakkul Trust in God's will, reliance on Him

Tawhid Unity or oneness of God

Tekke Dervish convent

'Ulama Theologians; singl.: 'alim

'Urafa Gnostics, singl.: 'arif

'Urs 'Wedding', a celebration to commemorate the death of a shaykh

Wahdat al-shuhud Concept of the 'unity of experience or witnessing'

Wahdat al-wujud Concept of the 'unity of being'

Walaya or Wilaya Spiritual territories or saintly realms

Wali Allah Friend of God

Waqf Religious endowment, pl.: auqaf

Zahir Exoteric

Ziyarat Shrine; visit to a tomb

Zuhd Asceticism, renunciation 


\section{Bibliography}

Abun-Nasr, J. (1965) The Tijaniyyah, Oxford: Oxford University Press.

Alam, M. and Subrahmanyam, S. (1998) The Mughal State, New Delhi: Oxford University Press.

Algar, H. (1975) 'Bibliographical Notes on the Naqshbandi Tariqat', in Hourani, G. (ed.) Essays on Islamic Philosophy and Science, Albany: State University of New York Press.

Algar, H. (1976) 'The Naqshbandi Order: A Preliminary Survey of Its History and Significance', Studia Islamica, 44, pp. 123-152.

Algar, H. (1991a) 'A Brief History of the Naqshbandi Order', in Gaborieau, M., Popovic, A. and Zarcone, T. (eds) Naqshbandis: Chimenments et situation actuelle d'un ordre mystique musulman. Actes de la table ronde de Sevres, 2-4 mai 1985, Istanbul: Isis.

Algar, H. (1991b) 'Political Aspects of Naqshbandi History', in Gaborieau, M., Popovic, A. and Zarcone, T. (eds) Naqshbandis: Chimenments et situation actuelle d'un ordre mystique musulman. Actes de la table ronde de Sevres, 2-4 mai 1985, Istanbul: Isis.

al-Haqqani an-Naqshbandi, Shaykh Muhammad Nazim Adil (1994) Mystical Secrets of the Last Days, Los Altos, CA: Haqqani Islamic Trust for New Muslims.

Ali-Shah, O. (1988) Course of the Seeker, Los Angeles: Tale Weaver.

Ali-Shah, O. (1991) Sufism for Today, Paris: Tractus.

Ali-Shah, O. (1992) The Rules or Secrets of the Naqsbbandi Order, Reno: Tractus.

Ali-Shah, O. (1994) The Sufi Tradition in the West, New York: Alif.

Ali-Shah, O. (1995) Sufism as Therapy, Reno: Tractus.

Anonymous (1982) Sufi Teachings, Buenos Aires: Dervish International Publications.

Anthony, D. (1978) 'Patients and Pilgrims: Changing Attitudes Toward Psychotherapy of Converts to Eastern Mysticism', in Richardson, J. T. (ed.) Conversion Careers in and out of the New Religions, Beverly Hills: Sage Publications.

Arasteh, R. A. (1974) Rumi the Persian, London: Routledge.

Arasteh, R. A. (1980) Growth to Selfhood, London: Routledge.

Arberry, A. J. (1992) An Introduction to the History of Sufism: the Sir Abdullab Subrawardy Lectures for 1942, New Dehli: Orient Longman.

Arjomand, S. A. (1981) 'Religious Extremism (ghuluww), Sufism, and Sunnism in Safavid Iran, 1501-1722', Journal of Asian History, 15, pp. 1-35.

Arjomand, S. A. (1988) The Turban for the Crown: the Islamic Revolution of Iran, Oxford: Oxford University Press.

Atay, T. (1994) Naqshbandi Sufis in a Western Setting, Ph.D. thesis, University of London.

Atay, T. (1999) 'The Significance of the Other in Islam: Reflections on the Discourse of a Naqshbandi Circle of Turkish Origin in London', Muslim World, 89 (July), pp. 455-477.

Baker, R. and Henry, G. (1999) Merton and Sufism: The Untold Story. A Complete Compendium, Louisville, KY: Fons Vitae. 
Bakhtiar, L. (1976) Sufi: Expressions of the Mysic Quest, London: Thames and Hudson.

Bakhtiar, L. (1993) God's Will Be Done I: Traditional Psychoethics and Its Personality Paradigm. II Moral Healer's Handbook: Centering the Self, III Moral Healing Through the Most Beautiful Names, Chicago: Kazi.

Ballard, R. (1990) 'Migration and Kinship: the Differential Effect of Marriage Rules on Processes of Punjabi Migration to Britain' in Peach, C. and Vertovek (eds) South Asians Overseas, Cambridge: Cambridge University Press.

Ballard, R. (1994) Desh Pardesh: the South Asian Presence in Britain, London: Hurst.

Ballard, R. (1999) 'Panth, Dharm, Kismet te Qaum: Four Dimensions of Punjabi Religion' in Singh, P. and Thandi, S. S. (eds) Punjabi Identity in a Global Context, Delhi: Oxford University Press.

Banner, L. (1998) Finding Fran, New York: Columbia.

Barboza, S. (1994) American Jihad: Islam after Malcolm X, New York: Doubleday.

Barks, C. (1994) The Essential Rumi, San Francisco: Harper Collins Publishing.

Barkun, M. (1974) Disaster and the Millennium, New Haven, Connecticut: Yale University Press.

Barton, S. (1986) The Bengali Muslims of Bradford: A Study of Their Observance of Islam with Special Reference to the Function of the Mosque and the Work of the Imam, Leeds: University of Leeds Community Religions' Project Monograph Series.

Bawa Muhaiyaddeen, M. R. (1971) The Wisdom of the Divine, Vol. 1, Columbo: The Serendib Sufi Study Circle.

Bawa Muhaiyaddeen, M. R. (1977) The Divine Luminous Wisdom that Dispels the Darkness. Philadelphia: Fellowship Press.

Bawa Muhaiyaddeen, M. R. (1979) Four Steps to Pure Iman, Philadelphia: Fellowship Press.

Bawa Muhaiyaddeen, M. R. (1980) The Truth and Unity of Man: Letters in Response to a Crisis, Philadelphia: Fellowship Press.

Bawa Muhaiyaddeen, M. R. (1981) Tasty Economical Cookbook, Vol. 2. Philadelphia: Fellowship Press.

Bawa Muhaiyaddeen, M. R. (1983), Sheikh and Disciple, Philadelphia: Fellowship Press.

Bawa Muhaiyaddeen, M. R. (1987) Islam and World Peace, Philadelphia: Fellowship Press.

Bawa Muhaiyaddeen, M. R. (1991) Questions of Life, Answers of Wisdom, Vol. 1, Philadelphia: Fellowship Press.

Bawa Muhaiyaddeen, M. R. (2001) K. Ganesan, trans., The Resonance of Allab: Resplendent Explanations Arising from the Nur, Allab's Wisdom of Grace, Philadelphia: Fellowship Press. (Published originally in Tamil in Sri Lanka in 1969 under the title Allabvin Mulakkam.)

Bayrak, T. (1985) The Most Beautiful Names, Putney, VT: Threshold Books.

Behl, A. and Weightman, S. (2000) Madhumalati: an Indian Sufi Romance, Oxford: Oxford University Press.

Berger, P. (1999) The Desecularization of the World: Resurgent Religion and World Politics, Grand Rapids: William Eerdmans.

Beyer, P. (1998) 'Globalizing Systems, Global Cultural Models and Religion(s)', International Sociology, 13(1), p. 90.

Bly, R. (1996) The Sibling Society, Reading, MA: Addison-Wesley.

Bly, R. (2001) The Night Abraham Called to the Stars, New York: HarperCollins.

Borella, J. (1992) 'Rene Guenon and the Traditionalist School' in Faivre, A. and Needleman, J. (eds) Modern Esoteric Spirituality, New York: Crossroad.

Boroujerdi, M. (1996) Iranian Intellectuals and the West: the Tormented Triumph of Nativism, Syracuse: Syracuse University Press.

Bottcher, A. (2000) 'The Naqshbandiyya in the United States'. Online. Available at: http:// www.naqshbandi.org. Visited September 2, 2003. 


\section{Bibliography}

Bowman, M. (1993) 'Reinventing the Celts', Religion, 23, pp. 147-156.

Bryson-Richardson, Mark. (1999) 'Cybertariqas: Sufism in the Diaspora, Identity and Virtual Community', Islamica, III/I, p75 Islamic Society, London School of Economics.

Buehler, A. F. (1998) Sufi Heirs of the Prophet: The Indian Naqshbandiyya and the Rise of the Mediating Sufi Shaykh, Columbia: University of South Carolina Press.

Bunt, G. R. (2000) Virtually Islamic: Computer-Mediated Communication and Cyber Islamic Environments, Cardiff: University of Wales Press.

Burckhardt-Qureshi, R. (1986) Sufi Music of India and Pakistan. Sound, Context and Meaning in Quawwali, Cambridge: Cambridge University Press.

Chittick, W. C. (1989) Ibn al-'Arabi's Metaphysics of Imagination. The Sufi Path of Knowledge, New York: State University of New York Press.

Chodkiewicz, M. (1986) Le Sceau des saints, Paris: Gallimard, Engl. transl. by Sherrard, L. (1993) Seal of the Saints, Cambridge: Islamic Texts Society.

Clarke, P. B. (1995) Mahdism in West Africa: the Ijebu Mabdiyya Movement, London: Luzac.

Clarke, P. B. (1998) New Trends and developments in the World of Islam, London: Luzac.

Clifford, J. (1997) Routes: Travel and Translation in the Late Twentieth Century, Cambridge, Mass.: Harvard University Press.

Cohn, N. (1970) The Pursuit of the Millennium: Revolutionary Millenarians and Mystical Anarchists of the Middle Ages, New York: Oxford University Press, Revised and Expanded edition.

Corbin, H. (1964) Histoire de la philosophie islamique, Paris: Gallimard.

Corbin, H. (1969) Creative Imagination in the Sufism of Ibn 'A rabi, trans. R. Manheim, Princeton: Princeton University Press.

Corbin, H. (1971) L’Homme de Lumière dans le soufisme iranien, Paris: Chambéry éditions Présence, translation by Pearson, N. (1979) The Man of Light in Iranian Sufism, Boulder and London: Shambala.

Corbin, H. (1976) Mystique Musulmane; Aspects et Tendances - expériences et techniques, 3rd edn, Paris: J. Vrin.

Curtis, R. H. (1999) 'Dispute Between U.S. Muslim Groups Goes Public', Washington Report on Middle East Affairs, April/May, pp. 71-101.

Dallas, I. (1988) The Book of Strangers, Albany: State University of New York.

Das Gupta, S. (1969) Obscure Religious Cults, Calcutta: Firma K.L. Mukhopadhyay.

De Jong, F. and Radtke, B. (eds) (1999) Islamic Mysticism Contested. Thirteen Centuries of Controversies and Polemics, Leiden: Brill.

Dobbin, Ch. (1983) Islamic Revivalism in a Changing Peasant Economy. Central Sumatra, 1784-18477, London: Curzon Press.

Dornbrach, H. (1991) Islamische Ordensgemeinschaften in Deutschland, Trebbus: Sufi-Archiv Deutschland e.V.

Draper, I. K. B. (1985) A Case Study of a Sufi Order in Britain, M.A. Thesis, Department of Theology, University of Birmingham.

Durkee, N. (1991) The School of the Shadhdhuliyyab: I Orisons, Alexandria: Dar al-Kutub.

Durkee, N. (1993) Embracing Islam: being some extracts from a tale of Exile, Virginia: Green Mountain School.

Eaton, R. (1984) 'The Political and Religious Authority of the Shrine of Baba Farid', in Metcalf, B. D. (ed.) Moral Conduct and Authority: The place of ADAB in South Asian Islam, Berkeley: University of California Press.

Eaton, R. (1993) The Rise of Islam and the Bengal Frontier, 1204-17600, Berkeley: University of California Press.

Eaton, R. (2000) Essays on Islam and Indian History, Delhi: Oxford University Press. 
Eickelman, D. F. (1981) The Middle East. An Anthropological Approach, Englewood Cliffs, New Jersey: Prentice Hall.

Eickelman, D. F. and Anderson, J. W. (eds) (1999) New Media in the Muslim World: The Emerging Public Sphere, Bloomington: Indiana University Press.

Eickelman, D. F. and Piscatori, J. (eds) (1990) Muslim Travellers, London: Routledge.

Eickelman, D. F. and Piscatori, J. (eds) (1996) Muslim Politics, Princeton, N.J.: Princeton University Press.

Eisenstadt, S. N. (1998) Die Antinomien der Moderne, Frankfurt: Suhrkamp.

Ernst, C. W. (1993) 'An Indo-Persian Guide to Sufi Shrine Pilgrimage' in Ernst, C. W. and Smith, G. M. (eds) Manifestations of Sainthood in Islam, Istanbul: Isis Press.

Ernst, C. W. (1994) 'The Interpretation of the Classical Sufi Tradition in India', Sụ̂fì , No. 22, pp. $5-10$.

Ernst, C. W. (1997) The Shambhala Guide to Sufism, London: Shambhala.

Ernst, C. W. (1999) 'Sufism and Philosophy in Mulla Sadra', Paper presented at World Congress on the Philosophy of Mulla Sadra, Tehran, May 23-27, unpublished.

Ernst, C. W. and Lawrence, B. (2002) Sufi Martyrs of Love: Chishti Sufism in South Asia and Beyond, New York: Palgrave Macmillan.

Esposito, J. (1995) The Oxford Encyclopedia of the Modern Islamic World, Oxford: Oxford University Press.

Fahim, S. S. (1995) Doris Lessing: Sufi Equilibrium and the Form of the Novel, New York: St. Martins Press.

Feild, R. (1976) The Last Barrier, San Francisco: Harper and Row.

Freidberg, D. N. (1994) The Naqshbandis in America, M. A. Thesis in Religious Studies, University of Colorado.

Frembgen, J. W. (1998) 'The Majzub Mama Ji Sarkar: “A friend of God moves from one house to another"', in Werbner, P. and Basu, H. (eds) Embodying Charisma: Modernity, Locality and the Performance of Emotion in Sufi Cults, London: Routledge.

Friedmann, Y. (1971) Shaykh A hmad Sirbindî. An Outline of His Thought and a Study of His Image in the Eyes of Posterity, Montreal: McGill University, Institute of Islamic Studies.

Fusfeld, W. E. (1981) The Shaping of Sufi Leadership in Delhi: The Naqshbandiyya-Mujaddidiyya (Ph.D. Thesis, University of Pennsylvania), Ann Arbor, Mich.: University Microfilms International.

Gabbay, T. (1988) A Discussion of Sufism and a description of a sample of American Sufi Practitioners, $\mathrm{Ph}$.D. Diss., California Institute of Integral Studies.

Gaborieau, M., Popovic, A. and Zarcone, T. (eds) (1991) Naqshbandis: Chimenments et situation actuelle d'un ordre mystique musulman. Actes de la table ronde de Sevres, 2-4 mai 1985, Istanbul: Isis.

Galin, M. (1997) Between East and West: Sufism in the Novels of Doris Lessing, Albany: SUNY.

Gammer, M. (1994) Muslim Resistance to the Tsar: Shamil and the Conquest of Chechnya and Daghestan, London: Frank Cass.

Geaves, R. A. (1996a) Sectarian Influences within Islam in Britain with reference to the concepts of Ummah and Community, Leeds: University of Leeds Community Religions' Project Monograph Series.

Geaves, R. A. (1996b) 'Cult, Charisma, Community: The arrival of Sufi pirs and their impact on Muslims in Britain', Journal of Muslim Minority Affairs, 16:2ff.

Geaves, R. A. (1999) 'Britain' in Westerlund, D. and Svanberg, I. (eds) Islam Outside the Arab World, London: Curzon.

Geaves, R. A. (2000) Sufis of Britain, Cardiff: Cardiff Academic Press. 


\section{Bibliography}

Geaves, R. A. (2001) 'The Haqqani Naqshbandis: A Study of Apocalyptic Millenialism within Islam', in Porter, S., Hayes, M. and Tombs, D. (eds) Faith in the Millenium, Roehampton Papers 7, Sheffield: Sheffield Academic Press.

Gellner, E. (1968) 'The Pendulum Swing Theory of Islam', in Robertson, R. (ed.) Sociology of Religion, Harmondsworth: Penguin.

Gellner, E. (1985) Leben im Islam. Religion als Gesellschaftsordnung, Stuttgart: Klett-Cotta Verlag.

Gilsenan, M. (1990) Recognising Islam: Religion and Society in the Modern Middle East, London: I. B. Tauris.

Göle, N. (1995) Republik und Schleier: die muslimische Frau in der modernen Türkei, Berlin: Babel. Gölpinarli, A. (1969a) Türkiye'de mezhepler ve tarikatlar, Istanbul: Inkilap Kitabevi.

Gölpinarli, A. (1969b) 100 Soruda Tasawuf, Istanbul: Gercek Yayinevi.

Graham, T. (1993) 'Abu Sa'id ibn Abi'l-Khayr and the School of Khurasan', in Lewisohn, L. (ed.) Classical Persian Sufism: from its Origins to Rumi, London: Khaniqahi Ni'matu'llahi.

Graham, T. (1999a) 'Shah Ni'matu'llah Wali: Founder of the Ni'matu'llahī Sufi Order', in Lewisohn, L. (ed.), The Heritage of Sufism, II: The Legacy of Medieval Persian Sufism, Oxford: Oneworld.

Graham, T. (1999b) 'The Ni'matu'llāhī Order Under Safavid Suppression and in Indian Exile', in Lewisohn, L. and Morgan, D. (eds) The Heritage of Sufism, III: Late Classical Persianate Sufism (1501-1750), Oxford: Oneworld.

Graham, W. A. (1977) Divine Word and Prophetic Word in Early Islam, The Hague: Mounton.

Gramlich, R. (1984) Muhammad al Ghazzalis Lehre von den Stufen der Gottesliebe, Wiesbaden/ Stuttgart: Franz Steiner.

Gramlich, R. (1989) Das Sendschreiben al-Qusairis über das Sufitum, Stuttgart: Franz Steiner.

Gramlich, R. (1990) Schlaglichter ïber das Sufitum; Ab̂̂u Nasr as-Sarrâgs Kitâb al-luma', Stuttgart: Franz Steiner.

Gramlich, R. (1992) Die Nabrung des Herzen; Abu Talib al-Makkis Qut al-Qulub, Stuttgart: Franz Steiner Verlag.

Gran, P. (1979) Islamic Roots of Capitalism: Egypt, 1760-18400, Austin, Texas and London: University of Texas Press.

Habibis, D. (1991) 'Mahdism in a Branch of a Contemporary Naqshbandi Order in Lebanon', in Gaborieau, M., Popovic, A. and Zarcone, T. (eds) Naqshbandis: Chimenments et situation actuelle d'un ordre mystique musulman. Actes de la table ronde de Sevres, 2-4 mai 1985, Istanbul: Isis.

Hagemann, L. and Albert, R. (1998) Dialog in der Sackgasse? Christen und Muslime zwischen Annäherung und Abschottung, Würzburg u. Altenberge 1999.

Halliday, F. (1992) Arabs in Exile, London: IB Tauris.

Hama, 'A. (1990) 'Mizan al-qiwa al-ijtima iyya bayn al-turuq al-sufiyya wa-harakat al-tajdid al-Islami fi 'asr al-nahda', in Markaz Dirasat al-Wahda al-'Arabiyya (Beirut), Al-din wa'lmujtama 'al-'arabi, pp. 327-338.

Hamzeh, N. A. and Dekmejian, R. H. (1996) 'A Sufi Response to Political Islamism: al-Ahbash of Lebanon', International Journal of Middle East Studies, 28: 217-229.

Hanegraaf, W. J. (1998) New Age Religion and Western Culture, Albany: SUNY.

Haqqani, M. N. al (1994) Mystical Secrets of the Last Days, Los Altos, California: Haqqani Islamic Trust for New Muslims.

Haqqani, M. N. al (1997) Princess Diana's Death, London: Zero Publications.

Hardy, F. (1983) Viraha Bhakti: the early history of Krishna devotion in South India, Delhi: Oxford University Press.

Harris, R. T. (2000) 'Reading the Signs: Unfolding Truth and the Transformation of Authority', in Webb, G. (ed.) Windows of Faith: Muslim Women Scholar-Activists in North America, Syracuse: Syracuse University Press. 
Hawley, J. (1988) Songs of the Saints of India Hawley, Oxford: Oxford University Press.

Hermansen, M. (1996) 'In the Garden of American Sufi Movements: Hybrids and Perennials', in Clarke, P. (ed.) New Trends and Developments in the World of Islam, London: Luzac.

Hermansen, M. (1999) 'Roads to Mecca Conversion Narratives of European and Euro-American Muslims', Muslim World, LXXXIX, pp. 56-89.

Hermansen, M. (2000) 'Hybrid Identity Formations in Muslim America: the Case of American Sufi Movements', Muslim World, XC, pp. 158-197.

Hermansen, M. (2003) 'How to Put the Genie Back in the Bottle? "Identity", Islam and Muslim Youth Cultures in America', in Safi, O. (ed.) Progressive Muslims: On Justice, Gender, and Pluralism, Oxford: Oneworld.

Hiskett, M. (1976) 'The Nineteenth-Century Jihads in West Africa', The Cambridge History of Africa, Vol. 5, Cambridge, pp. 125-169.

Hixon, L. (1988) Heart of the Koran, Wheaton, IL: Theosophical Publishing House.

Hixon, L. (1993a) Atom from the Sun of Knowledge, Westport, Conn: Pir Press.

Hixon, L. (1993b) Qalbi: Circle of Nur al-Jerrabi Newsletter, No. 2, Winter, p. 24.

Hizb-ut-Tahrir (n.d.) Online. Available at: http://www.hizb-ut-tahrir.org/english/definition/ messages.htm.

Hujwiri, 'A. b. 'U. al- (1953) Kashf al-Mahjub, transl. R. A. Nicholson, Lahore: Ashraf.

Hunwick, J. (1994) 'Sufism and the Study of Islam in West Africa: The Case of Al-Hajj 'Umar', Der Islam, 71(2), pp. 308-328.

Hussein, A. (2000) Émigré Journeys, London: Serpent's Tail.

Hüttermann, J. (2001) 'Sufitum in Deutschland', unpublished manuscript, Bielefeld.

Ibn 'Arabi (1988) La vie merveilleuse de Dhü-l-Nūn l'égyptian, trans. Deladrière, R., Paris: Sindbad.

Ibn 'Arabi (1992) What The Seeker Needs, trans. Bayrak, T. and Harris, R. T., Putney, Vermont: Threshold Books.

Inalcik, H. (1973) The Ottoman Empire; the Classical Age 1300-16000, London: Weidenfeld \& Nicolson.

Ireland, P. R. (1994) The Policy Challenge of Ethnic Diversity: Immigrant Politics in France and Switzerland, Cambridge, Mass. and London: Harvard University Press.

Islamic Supreme Council of America (1999). Online. Available at: http://islamicsupremecouncil.org/Statement/islamic_extremism.htm.

Islamic Supreme Council of America (1999). 'An Open Letter to All Muslims'. Online. Available at: http://www.islamicsupremecouncil.org/condemnation/ISCA_official_response. html. Visited December 21, 2001.

Islamic Supreme Council of America (2001). Online. Available at: http://www.islamicsupremecouncil.org/mission.htm. Visited December 21, 2001.

Islamic Supreme Council of America (2001) 'Space: the Final Frontier'. Online. Available at: http://www.islamicsupremecouncil.org/CountryReports/World_Tour_2001/SriLanka/may19/ default.htm. Visited December 21, 2001.

Islamic Supreme Council of America (2001) 'Naqshbandi America'. Online. Available at: http://www.islamicsupremecouncil.org/Spirituality/Naqshbandi/naqshbandi_america.htm. Visited September 27, 2003.

Joffe, G. (1998) 'Maghribi Islam and Islam in the Maghrib: the Eternal Dichotomy' in Westerlund, D. and Rosnander, E. (eds) African Islam and Islam in Africa, London: Hurst.

Jonker, G. (2002) Eine Wellenlänge zu Gott: Der Verband der Islamischen Kulturzentren in Europa, Bielefeld: transcript.

Jonker, G. (2004) 'Muslim Lay Communities between Turkey and Germany', in Malik, J. (ed.) Muslims in Europe. From the Margin to the Centre, Münster: LIT. 


\section{Bibliography}

Jonker, G. and Kapphan, A. (1999) Moscheen und islamisches Leben in Berlin, Berlin: Die Ausländerbeauftragte.

Kabbani, M. H. (1993) Mercy Oceans Secrets of the Heart, Fenton, Michigan: Haqqani Islamic Trust.

Kabbani, M. H. (1995) The Naqshbandi Sufi Way: History and Guidebook of the Saints of the Golden Chain, Chicago: Kazi Publications.

Kabbani, H. (1998) The Encyclopaedia of Islamic Doctrine, Vols 1-7, As-Sunna Foundation of America, Chicago: Kazi Press.

Kalra, V. (2000) From Textile Mills to Taxi Ranks, Aldershot: Ashgate.

Kamentz, R. (1995) The Jew in the Lotus, New York: Harper.

Kamilat (2001). Online. Available at: http://www.kamilat.org/fr_about.htm. Visited September 2, 2003.

Karrar, A. S. (1992) The Sufi Brotherhoods in the Sudan, London: Hurst.

Keller, K. (1991) 'Soufisme en Europe', in Waardenburg, J. (ed.) Scholarly Approaches to Religion, Interreligious Perceptions and Islam, Bern: Peter Lang.

Kepel, G. (2000) Jihad. Expansion et déclin de l'islamisme, Paris: Gaillimard.

Khan, H. I. (1982) The Gathas, Katwijk, Netherlands: Servire.

Khan, H. I. (1993) The Hand of Poetry, New Lebanon, NY: Omega Press.

Khan, P. V. (1974) Toward the One, New York: Harper and Row.

Khan, P. V. (1982) Introducing Spirituality in Counselling, Santa Fe: Omega Press.

Khosravi, S. (2000) 'www.iranian.com, An Ethnographic Approach to an Online Diaspora', in ISIM Newsletter, VI, October.

King, R. (1999) Orientalism and Religion: Postcolonial Theory, India, and 'The Mystic East', London: Routledge.

Knysh, A. (1999) Islamic Mysticism. A Short History, Leiden: Brill.

Kose, A. (1994) Conversion to Islam: a Study of Native British Converts, Ph.D. thesis, University of London.

Kose, A. (1996) Conversions to Islam, London: Kegan Paul International.

Koszegi, M. M. (1992) 'The Sufi Order in the West: Sufism's Encounter with the New Age' in Koszegi, M. A. and Melton, J. G. (eds) Islam in North America: A Sourcebook, New York: Garden Publishing.

Krishna, G. (1970) Kundalini: The Evolutionary Energy of Man, Berkeley: Shambhala.

Landolt, H. (1973) 'Der Briefwechsel zwischen Kâshânî und Simnânî über Wahdat al-Wujûd', Der Islam, L/1, pp. 29-81.

Lapidus, I. (1988) A History of Islamic Societies, Cambridge: Cambridge University Press.

Laughlin, M. (1999) Eating Poison: A Tale of Women and Discipleship in a Naqshbandi Sufi Community, M.A. thesis, International Studies, University of Washington.

Lawrence, B. (1978) Notes from a Distant Flute: Sufi Literature in Pre-Mughal India, Tehran: Imperial Iranian Academy of Philosophy.

Lessing, D. (1997) Walking in the Shade, New York: HarperCollins.

Levi-Strauss, Claude (1966) [1962] The Savage Mind, London: Weidenfeld and Nicholson.

Levtzion, N. and Voll, J. O. (1987) Eighteenth-Century Renewal and Reform in Islam, Syracuse: Syracuse University Press.

Lewis, F. (2000) Rumi: Past and Present, East and West, Oxford: Oneworld.

Lewis, P. (1994) Islamic Britain: Religion, Politics and identity amongst British Muslims, London: I. B. Tauris.

Lewis, P. (1997) 'The Bradford Council of Mosques and the Search for Muslim Unity' in Peach, C. and Vertovek (eds) Islam in Europe: the Politics of Religion and Community, London: Macmillan. 
Lewisohn, L. (1993) Classical Persian Sufism: from Its Origins to Rumi, London: Khaniqahi Ni'matu'llahi.

Lewisohn, L. (1999a) The Heritage of Sufism, Volume 3: Late Classical Persianate Sufism (1501-1750): The Safavid and Mughal Period, Oxford: Oneworld.

Lewisohn, L. (1999b) 'An Introduction into the History of Modern Persian Sufism', Bulletin of the School of Oriental and African Studies, LXI/3 [1998]: 437-464; LXII/1 [1999]: 36-59.

Lory, P. (1990) Les Commentaires ésotériques du Coran d'après 'Abd al-Razzaq al-Qashani, Paris: Les Deux Oceans.

Makarov, D. (2000) Ofitsial'nii I Neofitsial'nii Islam v Dagestane, Moscow: TsSPI.

Malik, J. (1998) 'The Literary Critique of Islamic Popular Religion in the Guise of Traditional Mysticism, or the Abused Woman', in Werbner, P. and Basu, H. (eds) Embodying Charisma: Modernity, Locality and the Performance of Emotion in Sufi Cults, London: Routledge, pp. 187-208.

Malik, J. (2003) 'Muslim Culture and Reform in 18th Century South Asia', Journal of the Royal Asiatic Society, 13(2), pp. 227-243.

Malik, J. (2004) 'Introduction', in Malik, J. and Reifeld, H. (eds) Religious Pluralism in South Asia and Europe, New Delhi: Oxford University Press.

Malti-Douglas, F. (1995) 'Arabic Literature: An Overview', in Esposito, J. L. (ed.) Oxford Encyclopedia of the Modern Islamic World I, New York: Oxford University Press.

Malti-Douglas, F. (2001) Medicines of the Soul: Female Bodies and Sacred Geographies in a Transnational Islam, Berkeley: University of California Press.

Mardin, S. (1989) Religion and Social Change in Modern Turkey. The Case of Bediuizzaman Said Nursi, New York: State University of New York Press.

Massignon, L. (1954) Essai sur les origines du lexique technique de la mystique musulmane, Nouvelle edition, Paris: J. Vrin.

Mazzaoui, M. M. (1972) The Orgins of the Safawids Shi'ism, Sufism, and Ghulat, Wiesbaden: Franz Steiner.

McCarthy, R. J. (2000) Al-Ghazali's Deliverance from Error (al-Munqidh min al-Dalal) and Other Works, Louisville: The American University in Cairo Press.

McLoughlin, S. (2004) Representing Muslims, London: Pluto.

Meier, F. (1957) Die Fawa'id al-gamal wa-fawatib al-galal des Nagm ad-din al-Kubra, Wiesbaden: Franz Steiner.

Meier, F. (1976a) Abu Sa'id ibn Abi'l Hair; Wirklichkeit und Legende, Teheran-Leiden-Paris: Brill.

Meier, F. (1976b) 'The Mystic Path', in Lewis, B. et al. (eds) The World of Islam. Faith, People, Culture, London: Thames \& Hudson.

Meier, F. (1992) 'Hurasan und das Ende der klassischen Sufik', in Glassen, E. and Schubert, G. (eds) Bausteine I, Istanbul: Franz Steiner Verlag.

Meier, F. (1994) Zwei Abhandlungen über die Naqšbandiyya, Stuttgart: Franz Steiner.

Metcalf, B. D. (1982) The Islamic Revival in British India: Deoband 1860-1900, Princeton: Princeton University Press.

Miller, B. S. (1977) Love Song of the Dark Lord: Jayadeva's Gita Govinda, New York: Columbia University Press.

Miskub, S. (1994) 'Nationalism, Centralization of Power and Culture in the Twilight of the Qajars and Dawn of the Pahlavis (Milligara'i, Tamarkuz u farhang dar ghurūb-i Qājāriyya va tulü'-i Pahlavī)', Iran Nameh, XII/3.

Moore, 'A. al-H. (1996) The Ramadan Sonnets, San Francisco: City Lights.

Moore, 'A. al-H. (2002) 'The Tonques of Poets' in Wolfe, M. (ed.) Taking Back Islam, Emmaus, Penn.: Rodale. 


\section{Bibliography}

Morris, J. (1992) 'Situating Islamic Mysticism: Between Written Traditions and Popular Spirituality', in Herrera, R. (ed.) Mystics of the Book: Themes and Typologies, New York: Peter Lang Publishing.

Munir, M. and Kayani, M. R. (1954) Report of The Court of Enquiry constituted under Punjab Act II of 1954 to enquire into the Punjab Disturbances of 1953 [The Munir Report], Lahore.

Muslim Student Association (2000) News site, 'Subject: Kabbani Affair: Comments on Sheikh Kabbani's Open Letter and Responses'. Online. Available at: http://msanews.mynet.net/ MSANEWS/20000622.5.html. Visited July 19, 2001.

Najafi, S. M. B. (2000) 'Mabānī-yi 'irfān dar Shāhnma' (Mystical Foundations of the Book of Kings), Șüfī, No. 48, pp. 6-15.

Nasr, S. H. (1991) Islamic Spirituality II: Manifestations, New York: Crossroad.

Nasr, S. H. (1995) 'Shihab al-Din Suhrawardi Maqtul', in Sharif, M. M. (ed.) A History of Muslim Philosophy, Dehli: D.K. Publishers (reprint).

Naumann, F. (2002) Wallace Putnam, New York: Abrams.

Nawruziyan, P. (1997a) 'Tāj-i Kay Khusraw bar sar-i Shaykh Ishrāq', part 1, Ṣūfī, No. 34, pp. 26-31; part 2, No. 35, pp. 26-34.

Nawruziyan, P. (1997b) 'Tāj-i Kay Khusraw', Șūfī, No 35, pp. 26-34. part 2, pp. 32-33.

Nawruziyan, P. (2000) 'Zartusht u hukamāyi bāstāni-yi Īrān', Șūfī , No. 49, pp. 12-18.

Nayyar, A. (1988) Qawwali, Islamabad: Lok Virsa.

Netton, I. (1982) Muslim Neoplatonists: An Introduction to the Thought of the Brethren of Purity, London: George, Allen \& Unwin.

Nicholson, R. A. (1906) 'A Historical Enquiry Concerning the Origin and Development of Sufism, with a List of Definitions of the Terms 'sufi' and 'tasawwuf', Arranged Chronologically', Journal of the Royal Asiatic Society, Part I, pp. 309-353.

Nicholson, R. A. (1914) Sarraj, A. N. al: Kitab al-luma' fi'l-tasawwuf, E. J. W. Gibb Memorial Series, 22.

Nicholson, R. A (trans., ed.) (1924-40) The Mathnawi of Jalalu'ddin Rumi, E. J. W. Gibb Memorial Series N.S., London: E. J. W. Gibb Memorial Trust, IV: 1039.

Nielsen, J. (1992) Muslims in Western Europe, Edinburgh: Edinburgh University Press.

Niffari, M. b. 'A. al (1935) The 'Mawaqif' and 'Mukhatabat' ... with other fragments, ed. and transl. A. J. Arberry, London: Luzac.

Nizami, K. A. (1991) 'The Naqshbandiyyah Order', in Nasr, S. H. (ed.) Islamic Spirituality: Manifestations, New York: SCM Press.

Nurbakhsh, J. (1981) Sufism: Meaning, Knowledge and Unity, trans. Chittick, W. and Wilson, P., New York: KNP.

Nurbakhsh, J. (1989) 'The Rules and Manners of Initiation into the Sufi Path', In the Paradise of the Sufis, 3rd edn, New York: KNP.

Nurbakhsh, J. (1991) 'The Ni'matu'llāhī', in Nasr, S. H. (ed.) Islamic Spirituality II: Manifestations, New York: Crossroad.

Nurbakhsh, J. (1994) 'Prayer and Fasting (namāz u rūza),' Chibil kalām u sī payām, Tehran, trans. 'Alireza Nurbakhsh (1996) entitled Discourses on the Sufi Path, New York: Khaniqahi Ni'matu'llahi Publications.

Nurbakhsh, J. (1995) Bāyazid Bis tami, publ. by the author.

Nurbakhsh, J. (1997) Shiblī: Mast-i Haqq va majdhūb-i haqūqat, London: KNP.

Nurbakhsh, J. (1999a) Foreword to Lewisohn, L. and Morgan, D. (eds) The Heritage of Sufism, III: Late Classical Persianate Sufism (1501-1750), Oxford: Oneworld.

Nurbakhsh, J. (1999b) Dhü'l-Nün Miṣrì: az mashāhīr-i dānishmandān u Șüfiyān-i miṣr, London: KNP.

Nurbakhsh, J. (2000) Pìrān-i Balkh, Tehran: Intisharat-i Yalda Qalam.

Oberoi, H. (1994) The Construction of Religious Boundaries, Delhi: Oxford University Press. 
O'Brien, A. (1911) 'The Mohammedan Saints of Western Punjab', Journal of the Royal Asiatic Society, 41, pp. 509-520.

O'Fahey, R. S. (1990) Enigmatic Saint: Abmad Ibn Idris and the Idrisi Tradition, London: Hurst.

O’Fahey, R. S. and Radtke, B. (1993) 'Neo-Sufism Reconsidered', Der Islam, 70, pp. 52-87.

Ozelsel, M. (1996) Forty Days: The Diary of a Traditional Solitary Sufi Retreat, Brattleboro, VT: Threshold.

Palmer, E. H. (1867) Oriental Mysticism, Cambridge.

Peskes, E. (1993) Muhammad b. 'Abd al-Wabhab (1703-92) im Widerstreit: Untersuchungen zur Rekonstruktion der Frübgeschichte der Wabhabiya, Stuttgart: Franz Steiner.

Peters, R. (1980) 'Idjtihad and Taqlid in 18th and 19th Century Islam,' Die Welt des Islam 20, pp. 131-145.

Pinto, D. (1995) Piri-Muridi Relationship: A study of the Nizamuddin Dargah, Delhi: Manohar.

Pockock, D. (1986) 'Art and Theology in the Bhagavad Purana' in Das, V. (ed.) The Word and the World, Delhi: Sage Publications.

Popovic, A. and Veinstein, G. (eds) (1985) Les Ordres Mystiques dans L'Islam; cheminements et situation actuelle, Paris: éditions de l'école des haute études en sciences sociales.

Pourjavady, N. and Wilson, P. L. (1978) Kings of Love: the History and Poetry of the Ni'matu'llähi Sufi Order of Iran, Tehran: Imperial Academy of Philosophy.

Radi, H. (2000) Hikmat-i khusravānī: hikmat-i ishrāq u 'irfān az Zartusht tā Subrawardī, Tehran: Intisharat-i bihjat.

Radtke, B. (1993) 'Gesetz und Pfad in der frühen islamischen Mystik. Einige Bemerkungen', in Bianchi, U. (ed.) The Notion of Religion in Comparative Research: Selected Proceedings of the XVI IAHR Congress, Rome: 'L'Erma' di Bretschneider, Storia delaa religioni.

Rahman, F. (1979) Islam, 2nd edn, Chicago: University of Chicago Press.

Rawlinson, A. (1997) The Book of Enlightened Masters, Chicago: Open Court.

Reps, P. (1961) Zen Flesh, Zen Bones, Garden City, NY: Doubleday.

Ritter, H. (1937) 'Philologika IX: Die vier Suhrawardî', Der Islam, 24.

Rizvi, S. M. (1980) History of the Dar al-Ulum Deoband Volume 1, Deoband: Dar al-Ulum.

Rocher, L. and Cherqaoui, F. (1986) D'une Foi L'autre, Paris: Editions du Seuil.

Roy, O. (1995) The Failure of Political Islam, London: Tauris.

Saad, J. B. (1996) The Image of Arabs in Modern Persian Literature, Maryland: University Press of America.

Sadat, M. H. (n.d.) Nuzhat al-arwah (Spirits' Delight), Mayil-Haravi, N. (ed.), Mashhad: Intisharat-i Kitabfurushi Zawwar.

Sadri, M. and Sadri, A. (eds, trans.) (2000) Reason, Freedom, and Democracy: Essential Writings of Abdolkarim Soroush, Oxford: Oxford University Press.

Safi, O. (2003) Progressive Muslims: On Justice, Gender, and Pluralism, Oxford: Oneworld Press.

Sanyal, U. (1996a) Devotional Islam and Politics in British India: Ahmad Khan Barelvi and his Movement, 1870-1920, Delhi: Oxford University Press.

Sanyal, U. (1996b) 'Are Wahhabis Kafirs: Ahmad Riza Khan Barelwi and His Sword of the Haramayn', in Messick, B., Powers, D. and Masud, K. (eds) Islamic legal Interpretation: Muftis and Their Fatwas, Cambridge: Harvard University Press.

Schiffauer, W. (1997) Fremde in der Stadt. Zehn Essays über Kultur und Differenz, Frankfurt/M.: Suhrkamp.

Schimmel, A. (1975, 1978) Mystical Dimensions of Islam, Chapel Hill, NC: University of North Carolina Press.

Schimmel, A. (1980) Islam in the Indian Subcontinent, Leiden: Brill.

Schimmel, A. (1981) Und Mubammed ist Sein Prophet. Die Verehrung des Propheten in der islamischen Frömmigkeit, München: Diederichs. 
Schimmel, A. (1982, 2001) As Through a Veil, Mystical Poetry in Islam. New York: Columbia University Press; Oxford: Oneworld.

Schimmel, A. (1985a) Mystische Dimensionen des Islam, Köln: Diederichs.

Schimmel, A. (1985b) And Muhammad is His Messenger, Chapel Hill, NC: University of North Carolina Press.

Schlessmann, L. (1991) 'Sufismus in Deutschland', Geographia Religionum, Vol. 7, pp. $143 \mathrm{ff}$.

Schlessmann, L. (1999) 'Sufi-Gemeinschaften in Deutschland', CIBEDO, 13.

Schmidt, G. (2004) 'Sufi Charisma on Internet', in Westerlund, D. (ed.) Sufism in Europe and North America, London: Routledge.

Schulze, R. (1990) 'Das Islamische Achtzehnte Jahrhundert. Versuch einer historiographischen Kritik', Die Welt des Islam, 30, pp. 140-159.

Schuon, F. (1976) Islam and the Perennial Philosophy, London: World of Islam Publishing.

Sedgwick, M. (2000) 'Marginal Muslims in Cyberspace: Traditionalism, New Communities, and the Blurring of Distinctions', in Utvik, B. O. and Vikor, K. (eds) The Middle East in a Globalized World: Papers from the Fourth Nordic Conference on Middle Eastern Studies, Bergen: Nordic Society for Middle Eastern Studies.

Sedgwick, M. J. (1987, 2004) Against the Modern World: Traditionalism and the Secret Intellectual History of the Twentieth Century, London: Crucible; New York: Oxford University Press.

Seufert, G. (1997) Politischer Islam in der Türkei. Islamismus als symbolische Repräsentation einer sich modernisierenden muslimischen Gesellschaft, Istanbul/München: Franz Steiner Verlag.

Seufert, G. (1999) 'Die Milli-Görüs-Bewegung (AMGT/IGMG): Zwischen Integration und Isolation', in Seufert, G. and Waardenburg, J. (eds) Turkish Islam and Europe, Stuttgart: Franz Steiner.

Shafii, M. (1968) 'The Pir (Sufi Guide) and the Western Psychotherapist', The R. M. Bucke Memorial Society Newsletter, No. 3, pp. 9-19.

Shafii, M. (1985) Freedom from the Self: Sufism, Meditation, and Psychotherapy, New York: Human Sciences Press.

Shafi'i-Kadkani, M. R. (1989) 'Talaqqi-yi qudama az watan', Majala-yi Alifbā, Vol. 2, Tehran: Amir Kabir.

Shah, I. (1983a) The Pleasantries of the Incredible Mulla Nasruddin, London: Octagon.

Shah, I. (1983b) The Exploits of the Incomparable Mulla Nasruddin, London: Octagon.

Shah, I. (1983c) The Subtleties of the Inimitable Mulla Nasruddin, London: Octagon.

Shakor, M. (1994) The Writing on the Water: Chronicles of a Seeker on the Islamic Sufi Path, Rockport, Mass.: Element Books.

Shamsher, J. (1989) The Overtime People, Jalandhar: ABS Publications.

Shils, E. (1981) Tradition, Chicago: Chicago University Press.

Shirvāni, Z. (1936) Būstan al-siyāḥat, Tehran: Kitābkhāna Sunā’̄.

Siddiqi, K. (1995) The Challenge (3:1), London: Muslim Parliament Network.

Simmons, G. Z. (2000) 'Striving for Muslim Women's Rights - Before and Beyond Beijing', in Webb, G. (ed.) Windows of Faith: Muslim Women Scholar-Activists in North America, Syracuse: Syracuse University Press.

Singh, K. (1991) The Hymns of Guru Nanak, Hyderabad: Orient Longmans.

Sirriyeh, E. (1999) Sufis and Anti-Sufis. The Defence, Rethinking and Rejection of Sufism in the Modern World, Richmond, Surrey: Curzon.

Smart, N. (1989) The World's Religions, Cambridge: Cambridge University Press.

Smirnov, N. (1963) Muridism na Kavkaze, Moscow: AN SSSR.

Smith, J. I. (1991) 'Seyyed Hossein Nasr: Defender of the Sacred and Islamic Traditionalism', in Haddad, Y. (ed.) Muslims of America, New York: Oxford University Press.

Spuler-Stegemann, U. (1998) Muslime in Deutschland, Freiburg: Herder. 
Steenbrink, K. (1993) Dutch Colonialism and Indonesian Islam. Contacts and Conflicts 1596-19500, Amsterdam: Rodopi.

Stephen, B. (1986) The Bengali Muslims of Bradford: A Study of Their Observance of Islam with Special Reference to the Function of the Mosque and the Work of the Imam, Leeds: University of Leeds Community Religions' Project Monograph Series.

Suhrawardi, Sh. al-D. M. (1982) The Mystical and Visionary Treatises of Subrawardi, transl. Thackston, W. M. Jr, London: Octagon.

Sulami, b. al-H. al (1983) The Way of Sufi Chivalry, trans. Jerrahi, T. B. al, Rochester, Vermont: Inner Traditions International.

Taeschner, F. (ed.) (1953) 'As-Sulami’s Kitab al-Futuwwa', in Studia Orientalia Joanni Pedersen ... dicata, Copenhagen.

Taeschner, F. (1979) Zünfte und Bruderschaften im Islam, Zürich: Artemis.

Tavakoli-Targhi, M. (2001) Refashioning Iran: Orientalism, Occidentalism and Historiography, New York: Palgrave.

Tenbruck, F. H. (1993) 'Die Religion im Maelstrom der Reflexion', in Bergmann, J., Hahn, A. and Luckmann, Th. (eds) Religion und Kultur, Opladen: Westdeutscher Verlag.

ter Haar, J. G. J. (1992) Follower and Heir of the Prophet: Shaykh Ahmad Sirbindi (1564-1624) as Mysticc, Leiden: Het Oosters Instituut.

Tracy, W. (1988) 'Dar al-Islam: The Code and the Calling', Aramco World Magazine (May/June), pp. 20-29.

Trimingham, J. S. (1971) The Sufi Orders in Islam, Oxford: Oxford University Press, Clarendon.

Troll, C. W. (ed.) (1989) Muslim Shrines in India, New Delhi: Oxford University Press.

Turner, V. (1979) Process, Performance and Pilgrimage, New Delhi: Concept.

Ul-Qadri, M. T. (1985a) Islam the State Religion, Lahore: Idara Minhaj ul-Qur'an.

Ul-Qadri, M. T. (1985b) Philosophy of Ijtihad and the Modern World, Lahore: Idara Minhaj ul-Qur'an.

Usborne, F. (1973) The Adventures of Hir and Ranjha, London: Owen.

Uwaysi, S. A. (Michael Brill Newman) (2000) The Gift of the Robe, San Rafael: International Association of Sufism.

Vaughan-Lee, L. (1998) The Face Before I Was Born, Inverness, CA: Golden Sufi Center.

Vaziri, M. (1993) Iran as an Imagined Nation: the Construction of National Identity, New York: Paragon.

Verter, B. (1998) 'Nativism', in Wuthnow, R. (ed.) The Encyclopedia of Politics and Religion, II, London: Routledge.

Vidich, A. W. (2000) A Living Sufi Saint: Shaykh Mubammad Nazim Adil al-Haqqani and the Naqshbandi Method of Self-Transformation, Ph.D. Thesis, Berne University.

Vikor, K. S. (1995) Sufi and Scholar on the Desert Edge. Muhammad b. 'Alî al-Sanûsî and His Brotherhood, London: Hurst.

Vishvanathan, G. (2000) 'The Ordinary Business of Occultism', Critical Inquiry, Autumn.

Voll, J. (1982) Islam: Continuity and Change in the Modern World, Boulder: Westview Press; Harlow.

Walbridge, J. (2000) The Leaven of the Ancients, Albany: SUNY.

Watanabe, T. (1999) 'A Holy War of Words in Islamic U.S.', Los Angeles Times, April 15.

Waterfield, R. (1987) Rene Guenon and the Future of the West, London: Crucible.

Webb, G. (1994) 'Tradition and Innovation in Contemporary American Islamic Spirituality: The Bawa Muhaiyadeen Fellowship' in Haddad, Y. and Smith, J. I. (eds) Muslim Communities in North America, Albany: State University of New York Press.

Webb, G. (1995) 'Sufism in America', in Miller, T. (ed.) America's Alternative Religions, Albany, New York: State University of New York. 


\section{Bibliography}

Webb, G. (1998) 'Teaching With Pictures: Three Paintings of Bawa Muhaiyaddeen', in Renard, J. (ed.) Windows on the House of Islam, Berkeley: University of California Press.

Werbner, P. (1990a) The Migration Process: Capital, Gifts and Offerings among British Pakistanis, Oxford: Berg Publishers.

Werbner, P. (1990b) 'Stamping the Earth with the Name of Allah: "Zikr and the Sacralising of Space among British Muslims”, Unpublished paper, Manchester: University of Manchester.

Werbner, P. (1998) 'Langar: Pilgrimage, Sacred Exchange, Perpetual Sacrifice in a Sufi Saint's Lodge', in Werbner, P. and Basu, H. (eds) Embodying Charisma: Modernity, Locality and the Performance of Emotion in Sufi Cults, London: Routledge.

Werbner, P. (2002a) Pilgrims of Love: the Anthropology of a Global Sufi Cult, London: Hurst Publishers; Tampa: Indiana University Press.

Werbner, P. (2002b) 'The Place which is Diaspora: Citizenship, Religion and Gender in the Making of Chaordic Transnationalism', Journal of Ethnic and Migration Studies, 28(1), pp. 119-134.

Werbner, P. (2002c) Imagined Diasporas among Manchester Muslims: The Public Performance of Pakistani Transnational Identity Politics, World Anthropology Series, Oxford: James Currey Publishers; Santa Fe: School of American Research Press.

Werbner, P. and Basu, H. (1998) (eds) Embodying Charisma: Modernity, Locality and the Performance of Emotion in Sufi Cults, London: Routledge.

Werbner, R. (1977) 'Introduction', in Werbner, R. (ed.) Regional Cults, London and New York: Academic Press.

Werbner, R. (1989) Ritual Passage, Sacred Journey: the Process and Organisation of Religious Movement, Washington D.C.: Smithsonian Institution Press.

Wilber, K. (1981) No Boundary: Eastern and Western Approaches to Personal Growth, Random House.

Wilson, P. L. (1993) Sacred Drift: Essays on the Margins of Islam, San Francisco: City Lights.

Wittek, P. (1938) The Rise of the Ottoman Empire (reprinted 1982), London: The Royal Asiatic Society.

Wolfe, M. (2002) Taking Back Islam: American Muslims Reclaim Their Faith, Rodale, Inc. and Beliefnet, Inc.

Yemelianova, G. (2001) 'Sufism and Politics in the North Caucasus', Nationalities Papers, 29, p. 4.

Zarrinkub (1978) Justujū dar tașawwuf-i İrän, Tehran: Amir Kabir.

Zayyani, K. (2001) 'Javānmardī dar āyina-yi tașawwuf (Chivalry in the mirror of Sufism)', in Süfī, No. 50, p. 27.

Zelkina, A. (2000) In Quest for God and Freedom, London: Hurst. 


\section{Index}

Abbasid Empire 4-6

Abdullah, Sufi 149

al-'Abidin Shirvani, Zayn 50, 58

Ahl-i Hadith 143

Abl-i Sunnat wa-jama'at 148-50, 152, 154-7

Ahmad Khan, Sayyid 144

Ahmadiyyas 162

Alfi-Thani, Mujaddid 129

Ali b. 'Uthman al-Jullabi al Hujwiri 3, 4

Ali-Shah, Omar 39

Allah Mian 163-4

allegory 36

America see United States

Anderson, B. 32

Anderson, J. 32, 42

Arasteh, Reza A. 41

As-Sunna Foundation of America

(ASFA) 118-19

asceticism 4, 59, 161-2

Baba, Meyer 88

Baghdad 7-8

Bakhtiar, L. 41

Banner, L. 37-8

Barelwis 144, 145-6; in Britain 147-8; in Punjab 168-9

Barks, C. 31

Basra 4

al-Basri, Hasan 4

Bawa Muhaiyaddeen Fellowship 30, 90, 91, 98-9; American origins 92-3; building of mosque 94-5; farming activities 95-6; inter-Sufi relations 98; key themes 93-4; mazar 96; media outreach 96-7; peace/justice involvement 97-8

Bawa Muhaiyaddeen, Muhammad Raheem 30, 87, 90, 98-9; American advent 92-3; and Iranian Revolution 97; key themes 93-4; in Sri Lanka 91-2
Bayrak, Tosun 89

Begum, Ora 88

Bhutto, Z. A. 64

Bin Laden, Osama 156

biography/autobiography 36

Birbank, D. 146

Birmingham 105, 131-3

Boroujerdi, M. 59

Bottcher, Annabelle 118

Britain: Abl-i Sunnat wa-jama'at 148-50,

152, 154-7; and Barelwis 147-8;

community tensions $142-3$; development

of Sufism 142-4; disaffected young

Muslims 156; ethnic loyalties 148-9,

152; Haqqaniyya tariqa 103-4, 105-7;

Naqshbandi-Haqqanis 150-52;

Naqshbandia Ghamkolia 129, 134;

neo-revivalist movements 155-7, 175,

182-4; Pakistani groups, heterogeneity

129-30; reformist movements $144-7,156$;

Wahhabi movements 146-7, 156, see also

Ghamkolvi, Sufi Sahib; Karim, Hajji;

Punjabi Islam, in Britain

Canada see North America

Chirkeevski, Shaykh Sayyid Effendi 109

Chishti, Mu'in al-Din 143, 170

Chishtiyya order 87; in Britain 143-4; in Punjab 169-72; theosophical

vision $170-71$

Clarke, Arthur C. 123

communities, religious, issues 90-91

comparative religious studies 88

conflict 23-4

conversion 37-8

Creator, and creation 163-4

Critchlow, K. 38

cults: expansion 127-9; features 130;

heterogeneity 129-30

Cyprus 40, 103, 107, 112, 116, 142, 150 
204 Index

Dagestan, Haqqaniyya tariqa 103, 104-5, 109-110

Daghestani, 'Abd Allah 116-17

Dajjal 122

Dar al-Ulums 144-5, 150

dars 129

Das Gupta, S. 172

da'wa 25, 84, 86, 92

Demartino, Richard 88

Denizolgun, Ahmad Arif 78

Deobandis 143; in Britain 144-5; Indian origins 144; in Punjab 168-9

dhikr 4, 7, 9, 14, 16, 19, 23, 30, 32, 37, 52, 73, 76, 79, 89, 94, 96, 106, 111, 127, 130, 132-35, 138, 147, 155

Diana, Princess of Wales 123-4

diasporic Sufism 20-25

Din, Dr Alam 137-9

Dornbrach, Abdullah Halis 72, 73, 79

Draper, I. K. B. 133-4

Durkee, Noorudeen 36-7

Durkee, Noura (Fran) 37-8

Eaton, R. 169

Eickleman, D. 32, 42

Ernst, C. 39, 146-7

Europe 1, 11, 13, 20, 25, 29, 32, 40, 51, 53, 71, 76, 82, 84, 106, 108, 113, 117, $122,131,140,149$

faiz 129

Fethullah 72, 79

figh 89, 154

futuwwalfutuwwat 8, 59, 64

Gellner, E. 147

Germany: attitudes to ICCs 75-6; Sufi presence 71-4, see also Sulaymancis

Ghamkolvi, Sufi Sahib: as organizer 130-35, 139-40; and Zindapir 134-5

al-Ghazzali 6, 60

Glastonbury 106

gnosis, structuralist models $135-7$

gnostic experience 160, 161

Godlas, A. 78

Gölpinarli, Abdülkadir 79

Graham, T. 50, 58

Guenon, R. 28

gyarvi sharif 127

hagiography $33,35,73,115$

al-Hakim al-Tirmidhi 4-5

al-Hallaj 5

balqas $73,75,83$
Halveti-Jerrahi Order of America 89

al-Haqqani, Shaykh Nazim 30, 40, 103, 116-18, 125, 150-51; adherents 110-111; Britain 105-7; Cyprus 116-17; Dagestan 109-110; Lebanon 107-9; teachings 111-12, 122-4

Haqqani Sufi Foundation 118

Haqqaniyya 34, 103, 104-5; Britain 103-4, 105-7; Dagestan 103, 104-5, 109-110; and Internet 112-13; Lebanon 103, 104-5, 107-9; membership 110-111; millennialism 106-7, 112; and political authority 111-12; transnationalism 113 , see also Naqshbandi-Haqqani order

Harris, Rabia Terri 89

Hartmann, R. 59, 61

Hazrat Inayat Khan 33-4, 35, 72, 87-8, 89

Helminski, K. 39

Helveti-Jerrahi Order 30

Hermansen, M. 49

Hisham, Shaykh see Kabbani, Shaykh Hisham

Hizb ut-Tahrir 146

Hoca, Fethullah 79

hybrid movements 28,30

Ibn 'Arabi 7-8, 170, 176

Ibn Khaldun 162

ICCs (Islamic Cultural Centres) 74-8, 81

Idara Mihaj ul-Qur'an 152-5, 156

identity questions 22-3

imitating Muhammad 80-83

Inayat Khan, Hazrat 33-4, 35, 72, $87-8,89$

India 75,81

Indo-Islamic cultural synthesis 171-2

Internet 32; in Germany 71-2; and

Haqqaniyya tariqa 112-13; and

Naqshbandi-Haqqani order, North

America 121; and Ni'matu'llahi

diaspora 55-6

Iranian Revolution 97

Islam: behavioural and spiritual dimensions 160-62; Indo-Islamic cultural synthesis 171-2; intercession 164; status of the Prophet 163

Islamic Cultural Centres (ICCs) 74-8, 81

Islamic Movement 145, 146

Islamic mysticism: formative phase 4-5; second phase $5-7$; third phase $7-8$; fourth phase 8 ; fifth phase $8-9$; sixth phase 10; seventh phase 10-11; cult expansion 127-30; North America 115-16; pluralistic nature 3; ritualization 6-7; and Sufism 2-4, 86-7 
Islamic Supreme Council of America

(ISCA) 118, 119

Islamist writings 30-31

Islamization 166

itjibad 9, 99, 101, 107, 153-4

Jama'at-i-Islami organizations 144, 145 , $153,175,182$

al-Jerrahi al-Halveti, Shaykh Muzaffereddin 89

jibad 9, 97, 144, 147, 151, 154

al-Jilani, 'Abd al-Qadir 152, 155

Jinnah, Muhammad Ali 129

jinns 130

Joffe, G. 147

jungian psychology 41

Kabbani, Shaykh Hisham 125, 155;

activities/teachings 111, 122;

anti-extremism 120; multi-nationalism 40;

origins $107-8$; systematic teaching 151 ;

in US 117-19, 152

Kabbani, Shaykhs Adnan and Hisham 40, $107-8$

Kacar, Kemal 74, 76-8

Kamilat Muslim Women's Organization 118, 119

Karim, Hajji 135-7

Keller, K. 73

khalifas 127, 128

Khalilu'llah, Shah 50

Khaniqah-i Ni'matu'llahi Press/Publications $56,61-2$

khatm al-awliya 4-5

Khumaini, Ayatollah 10, 97

Khurasan 4, 59

Khusravani tradition 58

Kose, A. 152

langar 127

Lapidus 170-71

Laughlin, M 40

lay communities 78-80

Lebanon, Haqqaniyya tariqa 103, 104-5, 107-9

lectures, transcribed 33-4

Lessing, Doris 31

literature 44; academic studies of Sufism 43; allegory 36; biography/autobiography 36; critical attention 30-31; dissemination networks 32-3; distributors/publishers 33; hagiography 35; and Internet 32; and multiple audiences 35-6; poetry 35; polemics $34-5$; in practice $31-2$; psychologies 41-3; quest novels 36; and rejection of terrorism 35-6; secret 33; and spiritual quest 38-9; transcribed lectures 33-4; transformation 36-8; and transnationalism $40-41$; and travel 38-9

localization 23

Lopez, D.S. 42

Madani, Khawaja Abu Hashim 87

mababba 4

Mabdi 106, 107, 108, 111, 112, 121-3

Majlis Ulema UK 144-5

malfuzat 34

Malti-Douglas, F. 31

Manchester 129-30, 131

Mardin, Sherif 79

marginalization 1-2

ma'rifa 4

Marouf, Pir 149

Massignon, L. 59, 60-61

Maududi, Maulana 10, 144, 153-4

Mawlawiyya see Mevlevi

mazars 9, 14, 95, 96, 164; intercession 164-6

Mevlevi 72, 106

Milad al-Nabi 152

millennialism 8, 15, 29, 104, 106-7, 112, $121-3,183$

Milli Gorüş 73, 74; as lay community 79; and Naqshbandi Mujaddidi 80 Map; and Naqshbandi-Khalidi 75 Map

Moubafiz-e-Haq 130-31

movements, western: identities 28-9, 43-4; and Islam 29-30, 31; membership 29

Muhaiyaddeen, Muhammad Raheem Bawa see Bawa Muhaiyaddeen, Muhammad Raheem

Muhammad, imitation 80-83

Muhammad Shah Qajar 50-51

Mubammadan Path 9

Muhammadiyya, tariqa 81,83

Mujaddid 6, 72, 117, 152, 154

Mujaddid Alfi-Thani 129

mysticism see Islamic mysticism

Nanak, Guru 172

Naqshband, Khawaja Baha' al-din 116

Naqshbandi Mujaddidi 71; and Milli Görus 80 Map

al-Naqshbandi, Shaykh Nazim Adil

al-Qibrusi al-Haqqani see al-Haqqani, Shaykh Nazim

Naqshbandi tariqa 104, 128-9 
Naqshbandi-Haqqani order 30, 40-41, 43-4, 71, 104-5, 153; in Britain 150-52; history 116-18; name change 117; public agenda 118-20, see also Haqqaniyya tariqa

Naqshbandi-Haqqani order, North America: anti-extremism 120; and Internet 121; and Islamic community 120-21, 124; long-term issues 124-5; membership 118; and millenialism 121-3; non-profit organizations 118-19

Naqshbandi-Khalidi: and Milli Görus 75 Map; name change 117

Naqshbandi-Mujaddidi order 129, see also Sulaymancis

Naqshbandia Ghamkolia 129, 134, 139-40, 149, see also Ghamkolvi, Sufi Sahib; Karim, Hajji

Naqshbandis-Hijaz 149-50

Na'san, Shaykh 107

Nasr, Seyyed Hossein 31, 38, 42

nationalism 13, 59, 61, 64

Nawruziyan, Dr Parviz 58-9

Nazim, Shaykh see al-Haqqani, Shaykh Nazim

neo-revivalist movements $155-7,175,182-4$

Nicholson, R. A. 60, 61

Ni'mattu'llah, Shah 49-50

$\mathrm{Ni}$ 'matu'llahi diaspora 49; English publications 61-3; ethnic composition 54-5; exodus/exile history 49-51; finances 55; gender relations 54; initiation procedures 52-3; and Internet 55-6, 72; numbers 51 ; organization/social structure 51-2; Persian publications 56-61; sacred nationalism 64; socio-political concerns 63-5; western migration 51

North America: Islamic mysticism 115-16, see also Naqshbandi-Haqqani order, North America; United States

Nuneaton 150

Nurbakhsh, Dr 51; and Persian origins of Sufism 56-8; publications 62-3

Nusrat Fateh Ali Khan 174, 181

orientalism in reverse 64

Ornstein, Robert 32

Ozak, Shaykh Muzaffer 30

Pakistan: cults 128-9; migration to Britain, heterogeneity 129-30; Muslim experience 162-4, see also Punjabi culture; Punjabi Islam

perennial movements 28-30

Persian Aryan theory 59-61
Persian Sufism see Ni'matu'llahi diaspora Philips, B. 146

Pics (public intellectual convert Sufis) 35

Pir Marouf 149

Pir Vilayat Khan 29, 38, 40, 41, 43, 88

Pir Wahhab Siddiqi 149-50

pir-bhailbhain 128

pirs 6, 7, 29, 62, 128, 135, 139,

$141,143,174,175$;

intercession 164-6

poetry 35

polemics 34-5

public intellectual convert Sufis (Pics) 35

Punjabi culture, historical roots $172-5$

Punjabi Islam: conversion process 169-72; critique of shrine worship 166; intercession practices 164-6; need for Islamization 166; pre-Islam 169; prescription v practice $167-9$

Punjabi Islam, in Britain 175; early pioneers 175-6; mosques,

development/organization 177-8; neo-revivalism 182-4; pirs, re-emergence 178-81; second generation 181-4; settlement 176-7

al-Qadir al-Jilani, Abd 7, 91, 92, 94, 127, 152,155

al-Qadir as-Sufi, Shaykh 'Abd 34, 36

ul-Qadiri, Muhammad Tahir 152-5

qawwalis 174,180

Quaid-i-Azam 129

quest novels 36

qutblqutbiyyat 92, 93-4, 98

reciprocities $24-5$

reformed Sufi organizations 153

reformist movements 144-7; and

disaffected young Muslims 156; and

Sufism 146-7, 156

regional cults 127-9; features 130

reintellectualization 42

religious communities, issues $90-91$

religious history, construction $20-22$

Reza Khan, Ahmad 143, 168-9

Rushdie, Salman 148, 163

sacred nationalism 64

Said Nursi 73, 79

saints, pirs 128

Salafi movement 10, 16, 18, 108, 120,

146-7, 151

salafiyya position 130

The Satanic Verses 148, 163 
Schlessmann, L. 73

Schmidt, G. 32

Schuon, F. 28-9

scientism 42-3

September 11th 156

Shafii, Muhammad 41

Shah, Bulleh 174

Shah, Idries 29-30, 31-2, 33, 41

Shah, Omar Ali 30

Shah, Waris 172-5

Shamsher, J. 176

Sheffield 105-6

Shi' ism 5-6

Siddiqi, Pir Wahhab 149-50

Sirhindi, Shaykh Ahmad 8, 20, 74, 83, 117, 129, 135

Smart, N. 61, 63-4

Smith Huston 31

spiritual quest 38-9

Sri Lanka 91-2

stories see literature

structuralist models 135-7

Sufi Abdullah 149

Sufi, etymology 3-4

Sufi Order of America/of the West 88, 89

Sufi Sahib Ghamkolvi see Ghamkolvi, Sufi Sahib

Sufi tourism 39

Sufism see Islamic mysticism

Suhrawardi 7, 58-9

Sulayman Hilmi Tunahan 74

Sulaymancis $73,74,83-4$; imitating Muhammad 80-83; lay communities 78-80; order descent 74-5, 79-80; organization 74-8; and women $82-3$ symbolic representation 23

ta'ifas $6,127,129,140$

taqlid 9

tariqas 103-5; as reformed Sufi organizations

153,156 ; and regional cults $127-30$

Tart, C. 41

tasawwuf 5, 6, 59, 64-5, 86

tawakkul 4, 58-9

Tholuck, F. R. D. 59-61 transcribed lectures 33-4

transformation 36-8

transnationalism 12, 15, 38, 40, 113, see also Haqqaniyya

transplant movements 29

travel 38-9

Trimingham, J. S. 147

Turkish Islam 78, 81-2

Turkish migrants 73-4, see also Sulaymançi

United Kingdom see Britain

United States 30, 31, 86-7; communes 38-9; comparative religion studies 88; first-wave Sufism 87-8; second-wave

Sufism 88-90; third-wave Sufism 90-91, 152; transplanted orders 89, see also Bawa Muhaiyaddeen Fellowship; North America

universalist movements $28-30,87,88$ 'urs festivals 6, 96, 127, 131, 133, $138,164,180$

Vaughan-Lee, L. 38

Vilayat Khan, Pir 29, 38, 40, 41, 43,88

viraha bhakti 171

Vishvanathan, G. 42

wahdat al-Wujud 8, 87, 170, 171

al-Wahhab, Ibn 'Abd 146

Wahhab Siddiqi, 149-50

Wahhabis 9, 10, 120, 146-7, 156

wali 128

wali Allab 86

wazifas 127

Webb, G. 31

Weber, M. 79

whirling dhikr 106

Wilber, K. 41

writings see literature

Zayyani, K. 59

Zindapir, Shaykh 128-9, 130-40 passim

Zoroatrianism 59

zuhd 4, 59 
